Pontifícia U U Uiversidade $C_{\text {Datónlca }}$

Debora Gill Fernandes

Re-pensar o humano a partir de Heidegger e

Derrida

Tese de Doutorado

Tese apresentada ao Programa de Pós-graduação em Filosofia da PUC-Rio como requisito parcial para a obtenção do grau de Doutora em Filosofia

Orientador: Prof. Paulo Cesar Duque Estrada 


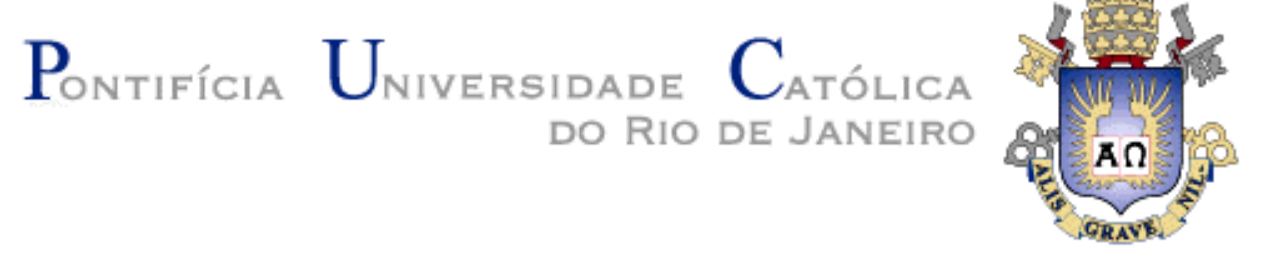

Debora Gill Fernandes

\title{
Re-pensar o humano a partir de Heidegger e Derrida.
}

\begin{abstract}
Tese apresentada como requisito parcial para obtenção do grau de doutor pelo programa de Pós- Graduação em Filosofia do Departamento de Filosofia do Centro de Teologia e Ciências Humanas da PUC-Rio. Aprovada pela comissão Examinadora abaixo assinada.

Prof. Paulo César Duque Estrada

Orientador

Departamento de Filosofia - PUC-Rio
\end{abstract}

Prof. Danilo Marcondes de Souza Filho

Departamento de Filosofia - PUC-Rio

Prof. Roberto Novaes de Sá

Universidade Federal Fluminense - UFF

Prof. Alexandre Marques Cabral Universidade do Estado do Rio de janeiro - UERJ

Prof. Alessandro de Magalhães Gemino Universidade do Estado do Rio de Janeiro - UERJ

Profa. Monah Winograd Coordenadora Setorial de Pós-Graduação e Pesquisa do Centro de Teologia e Ciências Humanas - PUC - Rio 
Todos os direitos reservados. É proibida a reprodução total ou parcial do trabalho sem autorização da universidade, da autora e do orientador.

\section{Debora Gill Fernandes}

Graduou-se em Psicologia na UERJ (Universidade Estadual do Rio de Janeiro) em 2010. Graduou-se em Administração com habilitação em Comércio exterior na ESPM (Escola Superior de Propaganda e Marketing) em 2008. Especializou-se Psicologia Clínica Fenomenológico-Existencial no IFEN (Instituto de Fenomenologia Existencial do Rio de Janeiro) em 2013. Tornou-se Mestre em Filosofia na PUC-Rio (Pontifícia Universidade Católica do Rio de Janeiro) em 2013. Fez doutorado sanduíche na Universidade de Paris X - Nanterre la Defense em 2015, sob a orientação do professor François-David Sebbah. Finaliza em 2017 sua tese de doutorado com o presente trabalho.

Ficha Catalográfica

Fernandes, Debora Gill

Re-pensar o humano a partir de Heidegger e Derrida / Debora Gill Fernandes ; orientador: Paulo Cesar Duque Estrada. - 2017. $224 \mathrm{f}$. ; $30 \mathrm{~cm}$

Tese (doutorado)-Pontifícia Universidade Católica do Rio de Janeiro, Departamento de Filosofia, 2017.

Inclui bibliografia

1. Filosofia - Teses. 2. Martin Heidegger. 3. Humano. 4. Psicoterapia. 5. Jacques Derrida. 6. Filosofia. I. Estrada, Paulo Cesar Duque. II. Pontifícia Universidade Católica do Rio de Janeiro. Departamento de Filosofia. III. Título. 


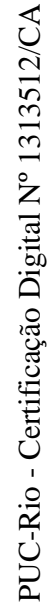

Aos meus queridos pais 


\section{Agradecimento}

Ao meu orientador Dr. Paulo Cesar Duque Estrada pelo apoio, tranquilidade e compreensão.

Ao Dr. Alexandre Marques Cabral, pela escuta, credibilidade, apoio e parceria na realização dessa pesquisa, com leituras constantes co-orientando constantemente este trabalho.

A toda banca examinadora pela participação no percurso deste trabalho e pela compreensão na realização dessa pesquisa.

Ao professor François-David Sebbah pela oportunidade e experiência em Paris X - Nanterre.

À PUC-Rio e à CAPES pelo auxílio concedido durante meu trabalho.

À Célia Maria Pereira por todo o acolhimento dado aos alunos da pós graduação da Puc-Rio.

Aos meus familiares: Branca Maria vieira Fernandes, Luiz Sergio Vieira Fernandes, Gladis Gill e Leonardo Gill pela paciência nos momentos de dificuldade.

À Rachel Bivar por todo apoio, paciência e compreensão na realização desse trabalho.

À Carol Mendes Campos, Michele Krimer, Taissa Zin, Aldo Falconi, Carlos Coelho, Fernanda Alt e Joni Mendrek pela ajuda, escuta e compreensão nos momentos difíceis.

Ao Therion, Maksim, Ishtar e Zoé pelo carinho e companheirismo em todos os momentos de realização desse trabalho. 


\section{Resumo}

Fernandes, Debora Gill; Duque Estrada, Paulo Cesar (Orientador). Repensar o humano a partir de Heidegger e Derrida. Rio de Janeiro, 2017. 224p. Tese de doutorado - Departamento de Filosofia, Pontifícia Universidade Católica do Rio de Janeiro.

Esta pesquisa tem como objetivo re-pensar o humano por meio da leitura de dois grandes pensadores, tendo em vista a existência do Dasein humano em Martin Heidegger e do rastro em Jacques Derrida. Repensar o humano se torna fundamental, na medida em que ele foi e é tomado como algo determinado ou determinável, como uma unidade que pode ser encontrada em sua essência e definida a partir de características específicas. Este modo de pensar e tomar o dito humano aparecem em diversos discursos sejam eles filosóficos, psicológicos ou do senso comum. O que resulta daí é uma relação com este suposto humano a partir de determinações pré-definidas, muitas vezes coisificadas, enclausuradas, tomadas como óbvias e, dessa forma, inquestionadas. Martin Heidegger foi um pensador de grande importância para repensar o humano, destruindo as bases que sustentavam as determinações deste e abrindo espaço para compreender outro modo de se relacionar com ele. A destruição metafísica do humano aparece em uma de suas obras capitais Ser e tempo (1927) a partir da analítica existencial do Dasein. Analítica esta fundamental para pensarmos o modo como Heidegger passa a re-pensar o humano e o lugar deste Dasein humano no início de seu pensamento. Em seguida, este Dasein humano será apresentado em obras mais tardias, onde Heidegger aborda o tema do humanismo de modo mais direto e apresenta a relação deste re-pensar junto à psicoterapia em seminários de Zollikon. Posteriormente a partir de uma desconstrução derridiana tentaremos abordar os limites desta destruição heideggeriana do humano, apontando alguns elementos de suma importância no pensamento de Jacques Derrida para que possamos alargar estes limites, re-marcando-os e transbordando-os. As obras utilizadas nesta passagem da pesquisa serão textos em que Derrida dialoga mais diretamente com Heidegger e aponta e acena para estas marcas e suas re-marcas. Por fim, será apresentado o re-pensar e o re-marcar o humano a partir de leituras derridianas em que o autor tangencia e responde às demandas e chamados de um "quem", um quem humano, um quem, talvez, derridiano. Tais remarcas terão como objetivo acenar para um re-pensar o humano a partir do rastro (Trace), 
fazendo tremer as supostas relações em jogo deste humano na filosofia, nas ciências humanas, na experiência diária e na psicoterapia.

\section{Palavras-chave}

Martin Heidegger; humano; psicoterapia; Jacques Derrida; filosofia. 


\section{Abstract}

Fernandes, Débora Gill; Duque Estrada, Paulo Cesar (Advisor). Rethinking the human from Heidegger and Derrida. Rio de Janeiro, 2017. 224p. Tese de doutorado - Departamento de Filosofia, Pontifícia Universidade Católica do Rio de Janeiro.

This research aims to re-think the human being through the reading of two major philosophers, thinking the Dasein's existence in Martin Heidegger and the trace in Jacques Derrida. Rethinking the human becomes fundamental once he was understood as something determined or determinable, as an unit that can be found in his essence and defined by specific characteristics. This way to think and understand the so called human appears in different speeches whether they are philosophical, psychological or from the common sense. Resulting in a relation with this so-called human within pre-defined determinations, often objectified, closed and taken as an obvious fact and, thus, unquestioned. Martin Heidegger was an important philosopher to the rethinking of the human on destroying the basis underlaying human determinations, making way to understand another approach on how to relate to him. The metaphysical destruction of this human appears in one of his capital works Being and Time (1927) and from the existential analytic of Dasein. This analytic is paramount to think how Heidegger starts to re-think the human and the place of this human Dasein at the beginning of his thought. Subsequently, this human Dasein will be presented in his later works, where Heidegger approaches the humanism theme more directly and presents the relation of this re-thinking with the psychotherapy in the Zollikon seminars. Furthermore, we will try to approach the limits of this heideggerian destruction of the human from a derridian deconstruction, pointing out some important elements from the thought of Jacques Derrida to be able to extend this limits, re-marking them and overflowing them. The texts used at this point of the research will be the ones in which Derrida dialogues more directly with Heidegger. Pointing out these marks and their re-marks. Finally, the human rethinking and re-marking will be presented from derridian readings, in which the author tangents and responds to the demands and calls of a "who", a human who, a who, maybe derridian. These remarks will aim to re-think the human from the trace, shaking this human's supposed relations, at stake in philosophy, in human sciences, in everyday experiences also in psychotherapy. 


\section{Keywords}

Martin Heidegger; human; psychotherapy; Jacques Derrida; philosophy. 


\section{Sumário}

1. Introdução 12

2. Heidegger: Dasein humano e a abertura existencial 17

2.1 A analítica existencial do Dasein 17

2.2. Carta sobre o humanismo: Dasein, próprio e linguagem 54

2.3. Seminários de Zollikon: o diálogo direto com a psicologia 66

2.4. Diferença ontológica 78

3. Derrida: diálogos com Heidegger 101

3.1. Metafísica da presença: logocentrismo 101

3.2. Diferença ontológica em Heidegger e Différance em Derrida 119

3.3. Verdade e ser - próprio e nós: o tema da proximidade em

3.4. Heidegger: ser, história e mundo em Ser e Tempo 131

3.5. Geschlecht 149

4. Derrida: espaço de alteridade como rastro no humano 164

4.1. Sujeito liquidado ou prometido? 164

4.2. Responsabilidade e decisão 179

4.3. O "humano" a partir do monolinguismo do outro 189

4.4. Humano como rastro 195

5. (In)Conclusão 210

6. Referências bibliográficas 219 
Eu que quero a coisa mais primeira porque é fonte de geração - eu que ambiciono beber água na nascente da fonte - eu que sou tudo isso, devo por sina e trágico destino só conhecer e experimentar os ecos de mim, por que não capto o mim propriamente dito.

Lispector, Clarice. Água viva 


\section{Introdução}

Esta pesquisa tem como objetivo pensar e re-pensar o humano, o que chamamos de humano, a partir de dois grandes pensadores: Martin Heidegger e Jacques Derrida. Acreditamos não termos (ainda) uma resposta suficiente acerca do que se chama humano e, que talvez esta resposta não seja de forma alguma encontrada, apreendida, compreendida de maneira total. Estes dois pensadores de maneiras diferentes já haviam acentuado esta impossibilidade. É importante ressaltarmos que resguardando as diferenças entre o modo como podemos "definir" o humano, nosso objetivo é acenar para aquele que chamamos de humano, sujeito, eu, homem (mulher), pessoa. Tendo em vista o que se entende pela identidade ou o processo de identificação do dito humano. O que estamos indicando como o dito humano, o suposto humano diz respeito ao modo como compreendemos, desdobramos, acenamos para o que chamamos humano. Existe certa pretensão em já saber o que o humano é, seus limites e definições. Falamos, dizemos, descrevemos sobre este humano, pressupondo que este humano possa ser de algum modo identificado. Nesse sentido, não vamos trabalhar em cima dos diferentes modos que utilizamos para nos referir ao humano, mas acenar para a possibilidade de repensarmos aquele que responde por humano, pelo que chamamos de humano. Este repensar será proposto a partir de um diálogo tendo como base a determinação existencial ${ }^{1}$ do Dasein humano pensado como abertura ao ser em Martin Heidegger e a diferança (differánce) no humano pensada como rastro e alteridade [abertura ao outro] em Jacques Derrida.

Este diálogo abrirá espaço para olharmos e repensarmos o dito humano na medida em que ele, muitas vezes, é coisificado, determinado, substancializado e fechado em modos específicos decorrentes de preconceitos herdados de uma tradição de pensamento. Esta maneira tradicional de lidarmos com o "humano" ao trazer e perpetuar a coisificação do outro, carrega consigo a certeza de que isto que se compreende por humano pode ser identificado e determinado a partir de tais ou tais aspectos. Tal identificação acaba muitas vezes fechando o humano

\footnotetext{
${ }^{1}$ Demos preferência pela tradução do termo existenciale por existencial de Marcia Cavalcanti ao invés de existenciário de Fausto Castilho. Com o intuito de manter a coerência do texto fizemos as alterações necessárias.
} 
numa unidade reconhecível, onde seus limites (suas bordas) estariam bem abordados. Seriam estes limites tão claros? Seria a identidade, a unidade deste humano compreensível em sua essência? Será que ainda podemos falar de essência? O que chamamos de ciências humanas, e assim incluímos a psicologia, acabaram herdando este olhar e lidando com o humano de maneira, muitas vezes, preconceituosa, naturalizada, inquestionada, prepotente e, sobretudo, fechada. A psicologia é um campo do saber institucionalizado que veicula a subjetividade moderna às suas práticas correlatas, a partir de Heidegger ela operacionaliza outra forma de pensar este campo psicológico dando espaço ao surgimento de uma psicologia existencial-fenomenológica. Vamos buscar ao longo desta pesquisa desconstruir, alargando e tremendo os limites do pensamento heideggeriano que davam base a estes discursos. Esta desconstrução será tecida a partir de um desdobramento realizado por Derrida.

Heidegger é um autor de suma importância para a destruição dos preconceitos da subjetividade moderna e para o deslocamento do humano como abertura ao ser. Sua análise teve profunda influência no pensamento acerca do "humano" principalmente a partir da analítica existencial do Dasein em uma de suas obras capitais Ser e tempo (1927). A determinação existencial do homem terá como base a abertura ao ser e a diferença ontológica, diferença entre ser e ente, como fundamentais, assim veremos ao longo da pesquisa. Esta determinação da essência do Dasein humano como abertura ao ser será trabalhada e alargada a partir do que Derrida chama de diferança e de rastro. $\mathrm{O}$ autor franco-magrebino deixa clara a necessidade de passarmos por Heidegger para, inclusive, compreendermos o que está em jogo em seu pensamento.

Neste sentido, pensamos como segundo capítulo, após o capítulo introdutório, descrever o que se compreende por humano em Heidegger a partir da analítica existencial do Dasein. Aos poucos iremos compreender como o jogo da existência está intimamente ligado à abertura ao ser e à diferença ontológica deste ente que nós mesmos somos. Esta relação Ser - Dasein humano sempre presente no pensamento de Heidegger será abordada em diferentes aspectos, apontando os elementos necessários que irão, porventura, surgir na nossa descrição. Heidegger foi um autor que nos mostrou que o que se compreende por humano jamais poderia ser pensado a partir da concepção objetiva e moderna do homem, pois tal concepção nos mostraria apenas um modo de ser homem característico de um 
horizonte histórico específico, sendo assim ela não responderia pelo próprio ser do homem, por sua essência nem por sua verdade. O que acaba nos sendo apresentado é uma destruição dos preconceitos metafísicos para repensarmos o humano a partir de um jogo existencial cuja abertura ao ser é marca fundamental e irredutível. Dessa forma, esta determinação da existência será descrita a partir da analítica existencial de Ser e tempo, obra fundamental para a compreensão do Dasein humano e um dos pontos de partida mais importantes para a compreensão do pensamento heideggeriano. Em seguida, pensaremos como a relação existencial pautada na ligação Ser-Dasein humano vai sendo apresentada a partir da noção de verdade e linguagem. Tal apresentação pode ser descrita contando com as obras Sobre o humanismo (1947), A essência da verdade (1943) e Introdução à metafísica (1935), obras um pouco mais tardias, revelando, sobretudo certo deslocamento do papel do Dasein no pensamento de Heidegger. Por fim, vamos pensar a maneira como a destruição heideggeriana da concepção moderna de homem e a abertura existencial em jogo em todo e cada Dasein humano influencia o pensamento sobre o dito humano, sobretudo no que diz respeito ao pensar psicológico. Neste ponto nos debruçaremos sobre os Seminários de Zollikon (1959-1969) em que Heidegger teve grandes diálogos com o campo da psicoterapia e da psiquiatria. Para que nosso caminho acerca da compreensão do Dasein como abertura ao ser e diferença ontológica seja compreendido perpassando seus diferentes momentos, dedicamos uma parte deste capítulo aos seus escritos mais tardios com intuito de nos aprofundarmos no deslocamento do papel do Dasein no pensamento deste autor. Neste sentido abordaremos, ainda que de modo breve, o pensamento da Ereignis e o repensar da própria diferença ontológica neste autor. Iremos desdobrar os textos $A$ constituição Onto-teo-lógica da Metafísica e o Princípio da Identidade em Identidade e diferença (1957).

Um terceiro capítulo será apresentado com o intuito de apresentar um diálogo de Derrida com Heidegger, tendo como foco certo alargamento e deslocamento deste pensar que toma o humano como uma unidade cuja abertura ao ser e a diferença ontológica o determinam de modo fundamental. Para pensar e re-pensar o humano a partir do jogo da diferença como diferança e da alteridade como rastro em Derrida. Tal diálogo se torna extremamente difícil, uma vez que não há de maneira clara e direta muitos textos que dialogam sobre a temática 
humana entre os dois autores. No entanto, a partir do momento que Derrida desconstrói e alarga o pensamento heideggeriano sobre a abertura ao ser e a diferença ontológica, ele alargaria ${ }^{2}$ também a própria determinação existencial assentada sobre esta abertura e diferença. Derrida possui uma relação intensa e cuidadosa com o pensamento heideggeriano, neste sentido, seus textos apoiam e alargam alguns elementos em Heidegger, mas sempre de modo a valorizar o pensamento deste autor, apontando em algumas passagens a necessidade de passarmos por ele como um pensador de suma importância para o pensamento da tradição e para ele mesmo. Nós nos debruçaremos, sobretudo, neste alargamento como transbordamento dos limites em jogo na abertura ao ser, na verdade do ser, na diferença ontológica, na relação com ser e na determinação existencial assentada sobre esta relação Ser-Dasein (humano). Com este capítulo vamos nos familiarizar com alguns elementos do pensamento derridiano para assim podermos pensar a própria diferança, que não está apenas atrelada ao humano em Derrida, mas será pensada aqui a partir dele. Dentre os textos escolhidos em que Derrida estabelece um diálogo com Heidegger, podemos citar: Os fins do homem (1968), A diferença (1968), o curso Heidegger: a questão do ser e a história (1964), Geschlecht I (1983) e Geschlecht II (1985), Do espírito: Heidegger e a questão (1987), Gramatologia (1967).

O quarto capítulo buscará pensar a diferança e o rastro em relação ao humano a partir do pensamento de Derrida. Em que medida a diferança descrita por Derrida pode ser pensada no humano? Como pensar a partir destes elementos uma relação possível com ele? Como esta relação estaria intimamente ligada à abertura ao outro e ao que ele chama de rastro? Seria a desconstrução como transbordamento, deslocamento de limites um modo de se relacionar e lidar com o humano? Este capítulo terá como intuito desdobrar o que chamamos de humano no pensamento derridiano, apresentando a questão da responsabilidade e da decisão inerentes ao chamado e à abertura ao outro. A pergunta pelo quem será deste modo re-pensada a partir do prisma da linguagem como escritura do outro, do rastro. Para isso trabalharemos com alguns textos em que o autor parece

\footnotetext{
${ }^{2} \mathrm{O}$ termo alargar aqui e ao longo do texto não diz respeito à uma ampliação de horizontes, mas à um fazer tremer, solicitar, abalar, desdobrar e desconstruir. Retirando as margens daquilo que parecia delimitado, transbordando-as. Derrida se utiliza deste termo Derrida (Ousia e gramme, In. Margens da filosofia, 1968/1991, p.67) ao dizer que ele tem a intenção de alargar a nota de Heidegger comentada neste texto. $\mathrm{O}$ termo se refere à tradução da palavra l'étendre.
} 
abordar esta relação no humano, tais como: il faut bien manger ou le calcul du sujet (1989), Monolinguismo do outro ou a prótese de origem (1996), a entrevista Le survivant, le sursis e le sursaut (2004). A partir daí algumas questões podem ser desdobradas: como poderemos compreender algo como o humano a partir do pensamento do rastro? Seria da ordem de uma compreensão? Talvez de um alargamento? Em que medida este pensamento pode dialogar com as ciências humanas, mais especificamente com a psicologia? Seria possível pensar uma psicologia a partir do rastro? A noção de desdobramento e alargamento acompanha o que estamos chamando de re-pensamento do humano, uma vez que a ênfase no prefixo "re" marca uma repetição, volta, talvez, infinita acerca do dito humano. Neste sentido, iremos desdobrar, alargar, re-marcar, re-pensar o humano a partir destes pensadores, tendo em vista que outras remarcações virão repensálo.

Este trabalho tem como objetivo introduzir este diálogo entre Heidegger e Derrida no que diz respeito ao desdobramento deles acerca do humano. Apresentando o alargamento e a desconstrução propostos por Derrida com relação aos limites relacionados à essência do Dasein humano como abertura existencial assentada na abertura ao ser. Não temos a pretensão de forma alguma em esgotar o que está sendo debatido e apresentado aqui. Nenhum rastro proposto por esta pesquisa é um fim e uma conclusão última, cada um deles é um caminho já aberto e aqui re-organizado, re-pensado para que outros rastros possam atravessá-lo. A costura realizada e tecida de maneira rigorosa em cada texto trazido pode abrir outros fios de tessitura. 


\section{Heidegger: Dasein humano e o espaço existencial}

\section{1}

\section{A analítica existencial do Dasein}

Para nos aproximarmos do que Heidegger compreende por humano, é necessária uma leitura rigorosa do que ele chama de analítica existencial. $\mathrm{Na}$ medida em que, é por ela que o já-compreendido humano é questionado em suas bases tradicionais. É por ela que podemos acenar para as diferenças com relação à própria tradição da psicologia, assentada numa tradição de pensamento metafísico. Desta forma, ao questionar a própria tradição, Heidegger estaria também questionando o humano e a relação com este humano no campo das ciências humanas e psicológicas ${ }^{3}$. A analítica existencial em sua obra Ser e tempo (1927) surge para Heidegger como base para chegarmos à sua questão fundamental: a pergunta pelo sentido de ser em geral, ou seja, a pergunta pelo ser do ente ${ }^{4}$. O autor alemão no Seminário de Zollikon (1965/2001) nos confessa:

o começo de todo o meu pensamento origina-se numa frase de Aristóteles que diz que o ente é expresso de muitas maneiras. Na verdade esta frase foi a faísca que provocou a pergunta: qual é a unidade destes significados múltiplos de ser; na verdade, o que significa ser? ${ }^{5}$

Para trilhar o caminho de resposta a esta pergunta, Heidegger precisava de um fio condutor para guiá-lo com segurança em direção ao seu problema em questão, que se mostrava segundo ele obscuro e insuficiente, visto que a tradição metafísica teria tomado durante todo seu percurso ser por ente, o que significa que a ontologia antiga teria compreendido ${ }^{6}$ ser a partir de um ente, "como se o ser tivesse o caráter de um ente possível" 7. Tais respostas seriam, para ele,

\footnotetext{
${ }^{3}$ Esta relação já foi abordada por muitos autores, mas ela se encontra todavia desdobrada por correntes de pensamento psicológico e autores diversos que se dividem entre Existencialistas, Daseinsanalistas, Gestalt terapeutas, Fenomenólogos e outros. Esta pesquisa não terá como abordar esta herança heideggeriana. Uma vez que o que se busca aqui é dialogar diretamente com o autor, buscando nele os questionamentos acerca do modo como se pensa o humano e partindo do pressuposto que foi a partir destes questionamentos que estas correntes psicológicas puderam ser pensadas.

${ }^{4}$ Heidegger, Ser e Tempo, 2012, p. 99

${ }^{5}$ Heidegger, Seminários de Zollikon, 2001, p.145 (Grifado nosso)

${ }^{6}$ Demos preferência por traduzir Verstehen por compreensão e não por entendimento como Fausto Castilho.

${ }^{7}$ Heidegger, Ser e Tempo, 2012, p.39
} 
insuficientes para a pergunta acerca do sentido de ser em geral, na medida em que respondem de modo obscuro e sem direção e não conseguem de uma vez por todas - satisfatoriamente - pôr fim na maneira como a pergunta é feita e nem alcançar uma resposta determinada ${ }^{8}$. Dessa forma, Heidegger vai buscar "elaborar de modo suficiente e de uma vez por todas o que é preciso para fazer a pergunta." 9 O primeiro passo seria "não contar uma história", ou seja, não responder pelo ser do ente a partir de outro ente, mas compreender que ser não é o mesmo que ente, no entanto, ser é sempre ser de um ente. Existe aí uma relação irredutível: ser ente, de modo que um não existe sem o outro. Diante de tal relação, Heidegger nos pergunta qual ente poderia servir de fio condutor para compreendermos o sentido de ser? Em qual ente o sentido de ser deveria ser acessado (zugänglich acessível), colhido, lido (abgelesen) ${ }^{10}$. Nada poderia responder por esta relação ser-ente a não ser aquilo que compreendemos por homem - o Dasein. O Dasein é o ente escolhido justamente pela proximidade que possui em sua relação com o ser, esta proximidade se mostra a partir de sua questionabilidade e compreensibilidade, de sua relação de sentido. Esta proximidade torna possível uma resposta acerca do ser de um ente, torna possível o acesso ao ser do ente, a leitura dele. Em seu texto Que é metafísica?, na introdução escrita em 1949, o autor retoma o termo Dasein nos advertindo que a palavra escolhida - Dasein não é de forma alguma uma palavra no lugar de algo como a consciência ou o que é representado pela consciência. Ou seja, ela não está no lugar de um sujeito que possui uma consciência e esta seria dotada de representações. O que está em jogo nesta palavra Dasein é "designado [como] aquilo que, pela primeira vez aqui, foi experimentado como âmbito, a saber, como o lugar da verdade do ser e que assim deve ser adequadamente pensado." 11 Ele continua, "o caminho tentado em Ser e tempo está 'à caminho' para situar o pensamento num caminho em cuja marcha possa alcançar o interior da relação da verdade do ser com a essência do homem." 12 Para pensarmos acerca do sentido de ser em geral, da verdade do

\footnotetext{
${ }^{8}$ Heidegger, Ser e Tempo, 2012, p.51

${ }^{9}$ Heidegger, Ser e Tempo, 2012, p.39

${ }^{10}$ Heidegger, Ser e Tempo, 2012, p.45

${ }^{11}$ Heidegger, Que é metafísica [introdução], 1949/1973, p.257

${ }^{12}$ Heidegger, Que é metafísica [introdução], 1949/1973, p. 256
} 
$\mathbf{s e r}^{13}$, é necessário uma reflexão sobre a essência do homem ${ }^{14}$. Fica mais clara, então, a necessidade da analítica existencial para Heidegger.

Mas por que afinal o homem teria esta relação fundamental de proximidade com o ser? Para compreendermos o Dasein é preciso termos em mente que este ente é o único que não possui sentidos a priori de modo que seu modo de existir é marcado por uma necessidade de sentido, é o sentido que sustenta a relação existencial, seria o sentido que sustentaria a própria relação com o ser. Pôr o ser em questão, ou querer sentidos, não acontece por vontade, nem por curiosidade, mas é a própria maneira do Dasein existir. O "homem" existe, pois se relaciona com o ser e tal privilégio e exemplaridade ôntico-ontológica se apresenta pelo que Heidegger denomina pré-compreensão de ser. Ele é a sede da compreensão de ser, palavras do autor em pé de página ${ }^{15}$. Nele pertence uma compreensão de ser de todo o ente não-conforme ao-Dasein, nele há a possibilidade de todas as ontologias. O Dasein é a pura expressão de ser, sua determinação essencial não é marcada por um conteúdo de coisa, não pode ser aplicado num modo de acesso dogmático, nem devem ser impostas categorias prévias, pois neste ente está em jogo seu próprio ser. "A pergunta pelo sentido de ser só é possível em geral se algo como a compreensão-de-ser é." ${ }^{16}$ Esta relação com o ser é a própria existência do Dasein. Para compreendermos o termo existência, ninguém melhor que o próprio autor para nos esclarecer. Em 1949 Heidegger em Que é metafísica [introdução] retoma e esclarece o termo existência apresentado em Ser e tempo:

A partir da 'existência' corretamente pensada se revela a 'essência' do Dasein, em cuja abertura o ser se revela e oculta, se oferece e subtrai, sem que esta verdade ${ }^{17}$ do ser no Dasein se esgote ou se deixe identificar com o Dasein ao modo do princípio metafísico: toda objetividade é, enquanto tal, subjetividade. Que significa 'existência' em Ser e Tempo? A palavra designa um modo de ser e, sem dúvida, do ser daquele ente que está aberto para a abertura do ser, na qual se situa, enquanto a sustenta. Este sustentar é experimentado sob o nome cuidado ${ }^{18}{ }^{19}$

A Existência esclarecida nesta obra Que é metafísica [introdução], 1949/1973, acena para uma insistência no fora, na abertura do ser, na abertura do

\footnotetext{
${ }^{13}$ Sentido do ser e verdade do ser em Ser e Tempo diriam a mesma coisa. Cf. Heidegger, Que é metafísica? [introdução], 1949/1973, p.259 Falaremos sobre a essência da verdade um pouco mais a frente nesta pesquisa.

${ }^{14}$ Heidegger, Que é metafísica? [introdução], 1949/1973, p.256

${ }^{15}$ Heidegger, Ser e Tempo, 2012, p.49

${ }^{16}$ Heidegger, Ser e Tempo, 2012, p.559

${ }^{17}$ A verdade do ser será descrita um pouco mais adiante nesta pesquisa.

${ }^{18} \mathrm{O}$ cuidado (Sorge) do Dasein diz respeito à unidade de ser deste ente e será esclarecido um pouco mais adiante nesta pesquisa

${ }^{19}$ Heidegger, Que é metafísica? [introdução], 1949/1973, p.257 (Grifado nosso)
} 
desvelamento do ser que é o modo do próprio ser acontecer como verdade. O sustentar dessa insistência na abertura do ser é assim, descrito, como a unidade de ser deste ente, o cuidado. O homem é o único ente que existe significa então: “o homem é aquele ente cujo ser é assinalado [privilegiado] pela in-sistência exsistente no desvelamento do ser [verdade do ser] a partir do ser e no ser." 20

A partir do $\$ 2$ de Ser e Tempo Heidegger vai nos descrever esta relação irredutível ser-ente(Dasein). É importante que tenhamos compreendido a irredutibilidade desta relação: o ser é sempre ser de um ente e o acesso ao ser do ente se dá a partir de um ente privilegiado cujo privilégio acena para seu próprio modo de ser como compreensão de ser do ente. Ou seja, o Dasein é o ente que nós mesmos somos, ente marcado por uma abertura ao ser do ente, por uma relação com o ser dos entes. Todo ser seria ser de um ente, numa relação em que ser determina o ente como ente ${ }^{21}$. Quando perguntamos o que é este ente? Ou mesmo o que é Ser? O é já estaria sendo compreendido previamente ${ }^{22}$. E por isso, “já nos movemos [nós -Dasein] em uma compreensão de ser" ${ }^{23}$, de modo que, "essa mediana e vaga compreensão de ser é um fato." ${ }^{24}$ Heidegger estabelece três componentes nessa relação Ser-ente (Dasein): aquilo de que se pergunta (Gefragte) neste caso, o Ser; aquilo que se pergunta (Erfragte), o sentido; e ainda nos falta aquele para quem se pergunta, pois a pergunta precisa ser feita a algo/alguém, a um ente, o a que(m) se pergunta, (Befragte) o Dasein ${ }^{25}$. Esta escolha se dá pela facilidade de acesso em que podemos colher/ler com mais segurança, sem falsificações, o sentido de ser, visto que é o ente, em que sendo, ele se questiona pelo sentido de ser. Existe aí uma facilidade de acesso e proximidade nesta relação e por isso, "elaborar a questão-do-ser significa tornar transparente um ente - o perguntante [Dasein] - em seu ser." ${ }^{26}$ Deste modo, Heidegger nos afirma que "se deve buscar na analítica existencial do Dasein a ontologia-fundamental, da qual somente todas as outras podem surgir."27

Existe no Dasein uma precedência e um privilégio ôntico-ontológico em relação aos demais entes. Uma vez que este é o ente que existindo compreende ser

\footnotetext{
${ }^{20}$ Heidegger, Que é metafísica? [introdução], 1949/1973, p.257

${ }^{21}$ Heidegger, Ser e Tempo, 2012, p.43

${ }^{22}$ Heidegger, Ser e Tempo, 2012, p.41

${ }^{23}$ Heidegger, Ser e Tempo, 2012, p.41

${ }^{24}$ Heidegger, Ser e Tempo, 2012, p.41

${ }^{25}$ Castilho, Fausto. Ser e Tempo, 2012, p.47 (Nota do tradutor)

${ }^{26}$ Heidegger, Ser e Tempo, 2012, p.47

${ }^{27}$ Heidegger, Ser e Tempo, 2012, p.63
} 
e, por isso, carrega a possibilidade de todas as ontologias. Desta maneira, o autor alemão vai nos questionar o modo de acesso a este ente, afinal, por onde começar a análise ${ }^{28}$ ? Esta será determinada a partir do modo como o Dasein está de início e na maior parte das vezes: na cotidianidade mediana. A analítica inicialmente buscará pôr à mostra o ser do Dasein para então compreendermos o sentido do ser deste ente: sua temporalidade ${ }^{29}$. O tempo é concebido como horizonte de toda compreensão e interpretação de ser do Dasein. Heidegger nos mostra a importância de nos atentarmos ao modo como a ontologia foi levada a cabo até agora, isto é, a partir de possibilidades ônticas do Dasein, ou seja, tomando ser por ente, coisificando, objetivando, fechando os modos possíveis de um ente se

28 "A análise no sentido freudiano seria, pois, uma recondução no sentido da decomposição a serviço da explicação causal. [...] O uso mais antigo da palavra análise encontra-se em Homero [...] significa aqui o desfazer de uma trama em seus componentes. [...] Muito mais tarde o filósofo Kant usa a expressão analítica em sua crítica da razão pura. Foi daí que tirei a palavra analítica, no título "analítica do Dasein". Mas isto não significa que a analítica do Dasein em Ser e Tempo seria apenas uma continuação da posição de Kant. [...] Este conceito kantiano de analítica mostra que ela é uma decomposição da faculdade de entendimento. O caráter fundamental de uma decomposição não é sua decomposição em elementos, mas a recondução a uma unidade (síntese) da possibilidade ontológica de ser dos entes, no sentido de Kant: da objetidade de objetos da experiência. Por isso também não pode haver aqui questão de uma causalidade que sempre só concerne a uma relação ôntica entre uma causa que é [Seienden] e um efeito que é [seienden]. A finalidade da analítica é, pois, evidenciar a unidade original da função da capacidade de compreensão. A analítica trata de um retroceder a uma "conexão em um sistema". A analítica tem a tarefa de mostrar o todo de uma unidade de condições ontológicas. A analítica como analítica ontológica não é um decompor em elementos, mas a articulação da unidade de uma estrutura. Este é o fator essencial no meu conceito "Analítica do Dasein".” (Heidegger, Seminários de Zollikon, 2001, p.141) - (Grifado nosso)

${ }^{29}$ Nós não vamos entrar nas estruturas temporais características da analítica existencial. Nosso objetivo é mostrar como o Dasein e suas estruturas revelam outro modo, mais aberto, de se compreender o dito humano. Apenas para esclarecer a temporalidade e o que Heidegger acentua sobre ela, segue a passagem a seguir dos Seminários de Zollikon, em que o autor nos descreve: "Quando eu coloco esta questão [a pergunta acerca do ser, a unidade dos significados múltiplos de ser], metodicamente o próximo passo é a pergunta: como posso desdobrá-la, onde há um fio condutor que me permita questionar o ser por ele mesmo? No passo seguinte, eu pesquisei os gregos [...] os gregos entendiam o 'ser como tal' no sentido de presença. Nesta determinação do ser, evidentemente o tempo está implicado. Pois presença é uma palavra que diz respeito a tempo. Porém, antes, deve ser perguntado como o tempo deve ser pensado aqui, na medida em que a usual representação de tempo é insuficiente até para poder discutir o problema do ser como questão. Esta compreensão levou à pergunta seguinte: como o homem mesmo se relaciona com o tempo, como o tempo determina o homem, de modo que ele possa ser interpelado pelo ser? Por este caminho a discussão da questão do ser é preparada por uma interpretação do Dasein humano sobre a temporalidade que lhe é própria.” (Heidegger, Seminários de Zollikon, 1965/2001, p.145) Em Ser e Tempo, Heidegger vai buscar destruir o tempo do ser como tradicionalmente pensado a partir da presença do agora, herdado desde Aristóteles, buscando assim pensar o ser a partir do tempo. (Heidegger, Seminários de Zollikon, 1965/2001, p.147) De modo semelhante, Heidegger também se refere deste modo à temporalidade de Ser e Tempo em Que é metafísica? [introdução] e em seguida acrescenta: "O tempo se torna o primeiro pré-nome que deve ser considerado para que se experimente o que em primeiro lugar é necessário: a verdade do ser. Assim como nos primeiros nomes metafísicos do ser fala uma essência escondida de tempo, assim também no seu último nome: no "eterno retorno do mesmo". Durante a época da metafísica, a história do ser está perpassada por uma impensada essência de tempo.” (1949/1973) p.258. Veja também Ser e Tempo, paragrafo 6. (Grifado nosso) 
mostrar e abandonando a questão do ser. Como modo-de-ser temporal o Dasein também é histórico ${ }^{30}$, no entanto, esta historicidade na maior parte das vezes está oculta (velada) e, por isso, pode se desocultar (desvelar). O perguntar pelo ser é caracterizado pela historicidade, dessa forma, a pergunta pelo sentido de ser requer uma apropriação mais autêntica, um acesso às fontes originárias nas quais os conceitos transmitidos e hauridos desde a ontologia antiga - grega - possam ser desvelados. Para isso torna-se necessário uma tarefa: a destruição deste conteúdo transmitido pela ontologia antiga até chegar às experiências originárias em que se conquistaram as primeiras determinações de $\operatorname{ser}^{31}$. Sem dúvida alguma, Heidegger não tem a intenção de se desfazer de toda tradição ontológica, até porque isso parece impossível, mas neste movimento que ele chama de destruição haveria um propósito positivo: o retorno ou o desvelamento dos conteúdos originários das primeiras determinações de ser.

Neste ponto de nossa narrativa podemos apontar uma questão que se mostrará em outros momentos. Heidegger parece apontar que os conteúdos transmitidos pela ontologia antiga - $(\text { grega })^{32}$ - nos trouxeram os preconceitos herdados e o esquecimento acerca do ser, a tradição transmite encobrindo, velando, obstruindo o acesso às fontes originárias, às primeiras experiências, às mais originárias experiências de determinação do ser. Por este motivo, o autor alemão tem como tarefa a destruição deste conteúdo transmitido pela ontologia antiga para termos acesso e recolocarmos de maneira suficiente a questão-do$\operatorname{ser}^{33}$. Tal destruição não deve ser tomada a partir de um ponto de vista moral, nem negativo, mas o que estaria em jogo seria um retorno a esta tradição buscando obter transparência e estabelecendo os limites na questão-do-ser.

Todas as ontologias devem tomar seu fio condutor a partir do Dasein $^{34}-$ o ser do homem - com o intuito de retomar a pergunta pelo ser, "conquistando um campo controlável [Feld kontrollierbarer] de confrontações." ${ }^{35}$ É assim que Heidegger termina o parágrafo 6 e inicia o 7 nos abrindo espaço para apresentar sua metodologia fenomenológica. A metodologia ontológica da tradição não poderia ser um caminho seguido por ele, visto que ela traria consigo os

\footnotetext{
${ }^{30}$ Heidegger, Ser e Tempo, 2012, p.81

${ }^{31}$ Heidegger, Ser e Tempo, 2012, p.87

${ }^{32}$ Heidegger, Ser e Tempo, 2012, p.85

${ }^{33}$ Heidegger, Ser e Tempo, 2012, p.87

${ }^{34}$ Heidegger, Ser e Tempo, 2012, p.95

${ }^{35}$ Heidegger, Ser e Tempo, 2012, p.99
} 
preconceitos e distorções transmitidos até hoje. Heidegger acaba rejeitando todos os métodos ontológicos até então apresentados, que se assentavam sobre a pergunta “o que é o ente?”, e recorre às próprias coisas, a partir da pergunta pelas "coisas elas mesmas". "O modo-de-tratamento dessa pergunta é o fenomenológico" 36 . Com este método o autor tenta fugir dos "o quês" que determinam quididativamente os entes, não nomeando nem caracterizando os conteúdos dos objetos de pesquisa, mas sua saída se dá pelo "como". Tal saída tem como intuito se opor aos conceitos flutuantes, só em aparência mostrados, e ao manejo técnico das disciplinas teóricas para desenvolver mais autenticamente uma abrangência dos princípios condutores de uma filosofia ${ }^{37}$. A fenomenologia se mostra como modo-de-acesso ao ser do ente, seu sentido, suas modificações e derivados. Seu acesso parece ter conquistado o campo controlável de confrontações, visto que por trás dos fenômenos não há essencialmente nada, ele desvela, descobre e apreende o mais originário dando a ontologia sua segurança metódica demandada. "O sentido metódico da descrição fenomenológica é interpretação." ${ }^{38}$ É por meio da hermenêutica ${ }^{39}$, como interpretação do ser do Dasein, que pode ser elaborado as condições de possibilidade de toda investigação ontológica. Pois a partir da descoberta do sentido de ser e das estruturas do Dasein "se põe à mostra o horizonte para toda outra pesquisa ontológica do ente nãoconforme ao Dasein." 40

É apenas no parágrafo 9 que entramos na analítica existencial do Dasein e que os caracteres essenciais desse ser passam a ser descritos. Heidegger introduz o parágrafo anunciando que este ente somos nós mesmos nos quais está em jogo o próprio ser. Ou seja, ao Dasein cabe-lhe responder pelo próprio ser, se haver com seu ser, ter seu próprio ser como seu. Desta relação intrínseca com seu próprio ser resultam dois caracteres: o ter-de-ser que é a própria e irredutível relação deste ente com seu ser. Em que sua existência - sua relação com ser - precede a essência, as possíveis determinações deste ente. Assim, o Dasein existe se essencializando em possíveis determinações de ser. E a segunda característica diz

\footnotetext{
${ }^{36}$ Heidegger, Ser e Tempo, 2012, p.101

${ }^{37}$ Heidegger, Ser e Tempo, 2012, p.101

${ }^{38}$ Heidegger, Ser e Tempo, 2012, p.127

${ }^{39}$ Nela (na hermenêutica) elabora-se ontologicamente a historicidade do Dasein. Hermenêutica está relacionada à interpretação, ao campo prévio de interpretações dadas num determinado horizonte histórico. (Heidegger, Ser e Tempo, 2012, p.127).

${ }^{40}$ Heidegger, Ser e Tempo, 2012, p.127
} 
respeito à sua minheidade, a impossibilidade de se distanciar deste ser que é cada vez seu. Uma vez que sendo, o Dasein se relaciona com seu ser, ele não tem como ser indiferente a ele. Tais características revelariam a impossibilidade de tomar este ente, bem como seus caracteres como coisas presentes adiante da mão ${ }^{41}$ (Vorhandenheit), substâncias, coisas dadas por si-mesmas, como acaba por fazer a tradição. O Dasein deve ser tomado a partir de seus modos-de-ser cada vez possíveis, como poder-ser. E como possibilidade ele pode ganhar-se, apropriar-se de si, de seu ser próprio, ou perder-se na impropriedade e no velamento de seu próprio ser. Ambas as possibilidades, para Heidegger, não se caracterizam por nenhuma gradação ética ou moral, em que uma seria melhor do que outra. O que o autor está apontando aqui é a própria impossibilidade de se tomar o Dasein como uma coisa presente adiante da mão, ou seja, não há neste ente nenhuma determinação de ser a priori, e justamente por isso, ele tem de se haver com seu ser, comportar-se diante de seu ser e ter seu ser como seu, sendo ele próprio ou impróprio.

[...] ao longo de Ser e tempo: a ontologia tradicional teria buscado compreender o ser dos entes intramundanos tomando por base a "substancialidade" das coisas naturais, isto é, tomando como parâmetro de explicação do ser dos entes intramundanos o caráter ontológico que seria próprio ao suposto ser da natureza, a substância, entendida como "fundamento de tudo. ${ }^{42}$

Vimos que esta relação irredutível Ser-ente, tem como base a relação SerDasein, pelo privilégio apontado deste ente em relação à questão do ser. Tal relação está assentada na impossibilidade de determinação deste ente de modo absoluto, substancial, sua indeterminação essencial o joga às distintas possibilidades de ser. O Dasein é um ser jogado diante de múltiplas e possíveis determinações de ser. Já neste ponto da narrativa, podemos pensar a quebra das visões psicológicas tradicionais que lidam com o dito humano a partir de determinações dadas, ou seja, acreditam que o humano possui características tais e tais antes mesmo de existir. Seu caráter de poder-ser revela justamente esta impossibilidade de determinação deste ente às últimas consequências e aponta para uma abertura aos possíveis modos de ser. Esta abertura, contudo, precisa de assentamento. Afinal, como o Dasein se determina, sendo marcado por

\footnotetext{
${ }^{41}$ Esta pesquisa deu preferência pela tradução de André Duarte do termo Vorhandenheit por presença adiante da mão, uma vez que este termo contém a palavra hand (mão) que queremos acentuar nesta pesquisa.

${ }^{42}$ Duarte, Vidas em Risco: crítica do presente em Heidegger, Arendt e Foucault. 2010, p.132
} 
possibilidade de ser? Da onde ou a partir de que surgem estas múltiplas possibilidades por meio das quais o Dasein pode se determinar? Do mundo. É o mundo que fornece as distintas possibilidades de ser do Dasein, de tal maneira, que ambos funcionam como uma unidade total: ser-no-mundo, um fenômeno unitário primário que deve ser visto como um todo ${ }^{43}$, sem bordas e sem limites externos. O que Heidegger busca apontar nesta unidade é a própria correlação intencional existente entre Dasein-mundo, destruindo assim, as visões tradicionais que manteriam separados o sujeito e mundo, por exemplo, como sujeito consciente representacional e o mundo como representação.

Nesta estrutura unitária - ser-em-um-mundo - compreende-se a estrutura Ser-em a partir da qual o Dasein pode estar jogado, absorvido em-um-mundo. O em - não significa de modo algum um dentro de, como se houvesse dois entes extensos, um presente adiante da mão dentro de outro. A preposição -em- do Serem, in em alemão, segundo Heidegger, proviria de innan que significa morar, habitar, demorar-se em. Existiria nesta estrutura uma relação de familiaridade, de casa, de absorção, de habitação e moradia. É justamente por ser um ente indeterminado, sem casa, sem moradia, que ele precisa de uma morada para ser, esta morada é o mundo. O Dasein é absorvido junto ao mundo. E o ser-em é esta instância onde a morada se dá, que assenta o Dasein-em-um-mundo. Este assentamento ou esta familiaridade se dão a partir de dois modos possíveis, ou seja, a "relação" ser-aí-mundo é onde o ser-aí (Dasein) se familiariza, tal familiaridade se dá a partir da relação junto aos entes em um mundo. O mundo é descoberto nesta relação junto aos entes no espaço de morada do ser-em. O ente que vem ao encontro pode ser descoberto a partir de dois modos: a ocupação (Besorge) com “algo" e a pre-ocupação (Fürsorge) com "alguém”. Todo vir-aoencontro do ente se dá em um espaço já descoberto, num "fora” junto ao ente no mundo, de modo que não haveria um comércio entre um sujeito e um objeto, nem um objeto apreendido e trazido para gaiola da consciência para então ser percebido $^{44}$. Todo perceber, conservar, reter, conhecer se dá fora e continua fora. O Dasein está jogado fora e assim permanece, uma vez que não haveria nenhuma interioridade psíquica ou corporal para a qual os sentidos e significados se voltariam. Não há qualquer interioridade no Dasein humano, ele não possui

\footnotetext{
${ }^{43}$ Heidegger, Ser e Tempo, 2012, p.169

${ }^{44}$ Heidegger, Ser e Tempo, 2012, p.193
} 
faculdades, nem mesmo corpo a priori. Todas as relações possíveis deste ente se dão em-um-mundo possível, em possibilidades dadas pelo mundo, fora do Dasein. A passagem de Sartre (1947) a seguir nos descreve de maneira muito interessante como a consciência intencional desenvolvida por Husserl estaria sempre fora. Tendo em vista as diferenças do pensamento sartriano e do pensamento heideggeriano, ambos são herdeiros de Husserl. Uma consciência intencional, nunca estaria dentro, interiorizando sentidos, significados ou representações, mas sempre fora. Este é o movimento do existir.

Conhecer, é "se manifestar rumo à", arrancar-se da úmida intimidade gástrica para esgueirar-se, longe, para além de si, rumo ao que não é si, longe, perto da árvore e, entretanto fora dela, pois ela me escapa e me repele e eu não posso mais me perder nela como ela não pode diluir-se em mim: fora dela, fora de mim. [...] não há nada nela [consciência], salvo um movimento para fugir de si, um deslizamento para fora de si; se, pela impossibilidade, vós entrares "numa" consciência, vós seríeis agarrado por um turbilhão e rejeitado para fora, perto da árvore, na plena poeira, pois a consciência não tem 'dentro'; ela não é nada senão o fora dela mesma e é essa recusa absoluta, essa recusa de ser substância que a constitui como uma consciência. ${ }^{45}$

O ser-em se mostra como o espaço de abertura a partir do qual o Dasein emum-mundo se ocupa numa lida familiar com os entes que vem ao encontro. Ele é a própria espacialidade do Dasein que, no parágrafo 23, será apresentado como um des-afastamento e um direcionamento, não a partir de uma distância e um espaço entre duas coisas presentes adiante da mão, mas a espacialidade se assenta a partir do que é visto na circunvisão, aberto por uma compreensão circunvisiva. O espaço coconstitui mundo e Dasein, na medida em que toda compreensão abre mundo. O aqui entendido pelo Dasein é o lá do mundo circundante ${ }^{46}$. Toda orientação do Dasein conhecida como espacial já está dada por um mundo. Para ver algo à direita ou à esquerda, aqui ou lá, um mundo já deve estar aberto. Veremos mais adiante como a abertura deste ente se mostra a partir da compreensão do Dasein. "Nem o espaço está no sujeito, nem o mundo está no espaço. Ao oposto, o espaço é "no" mundo, na medida em que o ser-no-mundo, constitutivo para o Dasein, abriu espaço [...] o Dasein é espacial em um sentido originário." ${ }^{47}$ Vai ficando cada vez mais claro o que Heidegger busca de todas as formas nos mostrar e com isso destruir na metafísica tradicional. Ele vai nos

\footnotetext{
${ }^{45}$ Sartre, Tradução do texto de Jean Paul Sartre: Une Idée fondamentale de la phenoménologie de Husserl: l'intentionnalité in. Situations I. (1947). 2005 (Ricardo Leon Lopes trad.), p.106

${ }^{46}$ Heidegger, Ser e Tempo, 2012, p.315

${ }^{47}$ Heidegger, Ser e Tempo, 2012, p.325
} 
descrevendo como os modos de ser do ente que nós somos não se dão, de forma alguma, a partir de faculdades cognoscíveis ou biológicas, nem mesmo o espaço é algo já dado, mas toda relação possível do Dasein se dá a partir de um mundo. E justamente por isso, ele é um ente privilegiado, na medida em que é o único ente que não possui sentidos a priori e precisa estar lançado em-um-mundo para que estes sentidos sejam possíveis.

Heidegger de maneira muito interessante nos mostra que de imediato o Dasein possui uma lida/trato (umgang) prática e não teórica. A descoberta do ente estaria desse modo, na lida prática com ele e não numa possível lida teórica. Ao descrever este modo de descobrir os entes, Heidegger se opõe mais uma vez a primazia das teorias tradicionais que partem de faculdades cognoscentes a priori em um sujeito para descrevê-lo. O conhecimento teórico só poderia acontecer a partir de um distanciamento do mundo prático, de modo que na deficiência, na não empregabilidade do ente em questão, por exemplo, na quebra do martelo no ato de martelar, a teoria acerca do martelo se tornaria possível. O que muda neste distanciamento é o modo de visão característico deste assentamento do ser-em, da absorção no mundo. O que acontece é que a partir desse distanciamento da lida prática junto ao ente, um espaço se abre à possibilidade de perceber a presença adiante da mão como algo e de determiná-lo enunciativamente - teoricamente. "Como modus deficiente de uma ocupação, o ficar perplexo diante de algo descobre a só-presença adiante da mão de um manual." ${ }^{48}$ Como vimos, em qualquer descoberta do ente que vem ao encontro, o Dasein jamais guarda algo dentro de si, pois está sempre fora e fora permanece, mesmo quando um conhecimento teórico é visto. A lida prática é primária no encontro junto aos entes, uma vez que o Dasein não possui faculdades a priori, não há nele nenhuma faculdade cognoscente para que esta lida primariamente fosse teórica. O que acaba por questionar muitos pensadores ou teóricos que tem por base a cognição, o conhecimento ou/e a consciência como essência do humano.

Estes caracteres do Dasein e outros que ainda serão brevemente apresentados são chamados de existenciais, as outras determinações-de-ser dos entes não conforme o Dasein chamamos de categorias. Existenciais e categorias são as duas possibilidades fundamentais de caracteres-do-ser.

\footnotetext{
${ }^{48}$ Heidegger, Ser e Tempo, 2012, p.225
} 
O ponto de partida da analítica, o acesso a este ente que nós mesmos somos, como já descrevemos, é onde este ente se encontra na maior parte das vezes, na indiferente cotidianidade mediana, em que preponderam a fuga diante do ser e o esquecimento desse $\operatorname{ser}^{49}$. A partir de onde podemos partir para pensar o mundo cotidiano no qual o Dasein se encontra na maior parte das vezes? Vimos que a lida em-um-mundo se dá pela ocupação com um ente. Num primeiro momento o Dasein se ocupa de um ente em-um-mundo. Para este ente que vem ao encontro no ocupar-se, o autor alemão chamou de utensílio (Zeug). O importante é atentarmos para o fato de que o utensílio não sendo o mesmo que coisa, ele não “é”. Ou seja, ele não é um ente isolado. O utensílio é algo para e aí reside uma remissibilidade, uma pertinência a outro utensílio, caracterizando o que podemos chamar de totalidade referencial utensiliar. Para o modo-de-ser do utensílio Heidegger utilizou o termo manuabilidade (Zuhandenheit), que ele vai afirmar também ser "a determinação ontológico-categorial do ente como ele é "em si"”, 50 . Vale acentuarmos que assim como a visão possui um lugar especial nesta obra e veremos o porquê, a mão também tem seu lugar cativo. Não vamos tão precipitadamente pensar que Heidegger está apenas falando da visão dos olhos e da mão do corpo. Estes dois elementos possuem características específicas que serão mais adiante esclarecidas.

A lida que emprega e maneja o manual possui uma visão própria e se subordina à multiplicidade da remissão do "para algo", este ver é um ver circunvisivo (Umsicht) que "caminha" por esta totalidade remissiva. Na lida cotidiana o Dasein se detém não nos utensílios, mas na obra, no que deve ser produzido, no para quê de sua empregabilidade. A obra remete também aos materiais e ao usuário e portador da obra. Esta totalidade remissiva demonstraria que no ente que vem ao encontro um mundo já é por nós pressuposto, ele já se deu. Esse mundo circundante só poderá ser descoberto quando a não possibilidade de empregar o material surpreende, esta não-pertinência do utensílio na totalidade remissiva é quebrada e com isso a circunvisão atesta o já-sempre visto e anunciado, o mundo. O mundo deve desaparecer novamente para que o manual possa ser visto. “A circunvisão tropeça, cai no vazio [Leere] e só agora vê para

\footnotetext{
${ }^{49}$ Heidegger, Ser e Tempo, 2012, p. 145

${ }^{50}$ Heidegger, Ser e Tempo, 2012, p.219
} 
quem e com que o que falta era manual"51. A circunvisão vê a anunciação do mundo circundante. Mas a anunciação do mundo neste vazio impede que o ente seja estruturado como em-si do manual ${ }^{52}$.

Assim como o caráter de ser do utensílio era o manual, o caráter de ser do manual é o que Heidegger denominou conjuntação (Bewandtnis), o ser do manual tem esta estrutura de remissibilidade - com...junto. Poderíamos pensar numa ampliação do que já havia entre os utensílios como totalidade remissiva. Com o ser do ente no interior do mundo - o utensílio, tínhamos a totalidade remissiva ou referencial, com o ser do manual, Heidegger aponta a totalidade conjuntural. Esta por sua vez retrocede remissivamente a um para quê, junto ao qual não há mais conjuntação, seria um último para quê, da onde, talvez, todos os para quês brotariam. Este para-quê primário é um em-vista-de-quê que concerne sempre ao ser do Dasein ${ }^{53}$. O deixar que se conjunte é condição de possibilidade para que o manual venha ao encontro. Esse deixar-ser, deixar que se conjunte, é um pôr em liberdade, que descobre, que deixa que seja em sua verdade, é um a priori que caracteriza o modo de ser do Dasein e condição para que o manual venha ao encontro. $O$ ente descoberto já é cada vez um manual. O deixar-ser manual é um modo a priori que caracteriza a própria unidade ser-no-mundo. Neste ponto compreenderemos a ligação entre a mão do manual e a visão compreensiva, bem como sua relação com a unidade ser-no-mundo.

Para que o ente venha ao encontro e seja descoberto como manual, este pôr em liberdade deve estar previamente aberto. Esta prévia abertura é a própria compreensão de ser do Dasein ${ }^{54}$. Abertura, compreensão e existência caracterizam o Dasein, uma vez que este ente não pode mais ser tomado como algo previamente dado, mas seus modos de ser dependem de um modo de abertura específico a partir do qual algo pode ser compreendido no movimento existencial deste ente que nós mesmos somos. Tal abertura é fundamental para a quebra do fechamento compreensivo que a tradição tomou acerca de nós mesmos e dos entes junto aos quais sempre estamos. Fechamento que diz respeito a uma substancialização, uma coisificação e uma visão limitada por preconceitos prévios herdados historicamente. O que estamos tentando mostrar aqui é que Heidegger

\footnotetext{
${ }^{51}$ Heidegger, Ser e Tempo, 2012, p.227-228

${ }^{52}$ Heidegger, Ser e Tempo, 2012, p.229

${ }^{53}$ Heidegger, Ser e Tempo, 2012, p.253

${ }^{54}$ Heidegger, Ser e Tempo, 2012, p.257
} 
faz um movimento de suma importância para nos abrir diante dos limites nos quais nos achávamos inseridos e assegurados. Esta abertura é um dos caracteres mais fundamentais para se contrapor às ciências naturais, às substancializações e ao modo como a tradição via o que se compreende por humano. O que Heidegger busca apontar em alguns de seus textos é que as ciências acabaram por esquecer o Ser, dissimulando-o, abandonando-o, se ocupando de modo fechado e preconceituoso dos entes ${ }^{55}$. Neste sentido, o autor vai buscar nos abrir para a própria abertura ao ser e do ser, ela (a abertura do que compreendemos por humano) se torna um ponto chave e tema da nossa pesquisa. O que se compreende por humano não pode mais ser absolutizado em um ou mais modos de ser determinados e nem os entes podem ser substancializados ou objetivados isoladamente em características tais e tais. A abertura do Dasein quebra com esta absolutização e nos joga num jogo de remissibilidade onde nada é, senão em relação com, para algo, para quê, em vista do quê, onde o assentamento se daria num ser aberto à, no próprio Dasein que compreende ser. Neste sentido é importante nos debruçarmos acerca deste caráter compreensivo do ente que nós mesmos somos.

Descrevemos já no início deste trabalho, ainda que brevemente, a relação compreensiva do Dasein, como o modo de ser deste ente. Sendo, o Dasein compreende ser. Tal característica não está de modo algum relacionada a uma possível faculdade do Dasein, mas é o próprio modo dele existir. Compreender ser é o mesmo que existir. O Dasein sempre já compreendeu algo em virtude de uma possibilidade sua. A Compreensão abre espaço para que algo possa ser visto. Na visão compreensiva o Dasein vê possibilidades a partir das quais ele é. Esta relação visão-manual é base para compreendermos o ser-no-mundo, na medida em que o ente que vem ao encontro é descoberto a partir de uma compreensão que vê o manual. Tanto o manual quanto a visão possuem uma unidade remissivorelacional, ou seja, em última instância um se relaciona com o outro, de modo que um não é sem o outro, a visão vê manual e manual é visto por visão compreensiva. Talvez pudéssemos recordar aqui a célebre frase fenomenológica em que toda consciência é consciência de $\operatorname{algo}^{56}$. Sem dúvida Heidegger não fala

\footnotetext{
55 "Ela [a ciência] se ocupa unicamente do ente." Heidegger, Que é metafísica? 1929/1973, p.234

${ }^{56}$ A intencionalidade da consciência é, ainda que de maneira diferente, herdada pelo pensamento heideggeriano nesta obra. Vale acentuar que alguns autores consideram que em Husserl e Brentano
} 
mais de uma consciência intencional, mas o que está em jogo é a intencionalidade como unidade de mundo e Dasein, de compreensão de sentido de ser de entes emum-mundo.

Deve-se deixar claro mais uma vez que o manual para Heidegger não está intimamente relacionado com a mão corporal, mas possui dela certa "apreensibilidade", apropriação, de modo que, um manual é aquilo que podemos apreender, agarrar, pegar, nos apropriar, não necessariamente de modo físico, corporal, mas o que está em jogo é a apreensão de seu sentido e significado. Dessa forma, o ente apreendido não estaria apenas relacionado às coisas palpáveis, mas estaria relacionado ao próprio modo de compreensão de um ente. Heidegger não está descrevendo um modo de apreensão em que arbitrariamente colocamos categorias e "vestes" em um determinado ente. O que se mostra aqui é a própria maneira do ente ser encontrado, descoberto, compreendido e visto. O próprio autor utiliza estas palavras em diferentes contextos como modo compreensivo. Nas palavras dele, "compreender a fenomenologia consiste em apreendê-la [ergreifen] unicamente como possibilidade." ${ }^{, 57}$ Em outra passagem ele também nos diz: "O Dasein [...] já entrou sempre em determinadas possibilidades e, [...] deixa que algumas possibilidades passem, abrindo mão constantemente de possibilidades de seu ser, quer as apreenda [ergreift], quer não." 58 "Na interpretação, o compreender, compreendendo, apropria-se (eignet sich) do seu compreendido." ${ }^{59}$ O Dasein é o ente que pode apreender e apropriar-se de possibilidades, que pode compreender possibilidades. Manejando um utensílio, por exemplo, o martelo, ele se mostra em seu martelar. Tal martelar não é nunca apreendido teoricamente ${ }^{60}$. A mão inclusive seria um possível manual, como um ente que vem ao encontro, como possibilidade a ser apreendida. A visão da compreensão, por sua vez, não é a visão dos olhos, mas ela traz consigo a característica da claridade/transparência que a visão do olhar possui. Já que a visão põe à luz, descobre e desvela o ente, o manual em seu vir ao encontro. Nas palavras do próprio Heidegger, “o manual vem expressamente se pôr ante a visão-

\footnotetext{
a consciência não é deslocada, se mantendo como ponto de apoio para o mundo. Em Heidegger até mesmo a "consciência" possuiria seu deslocamento, ela também estaria fora, no mundo. Veja Derrida, Heidegger: la question de l'Être et l'Histoire, 2013.

${ }^{57}$ Heidegger, Ser e Tempo, 2012, p.131

${ }^{58}$ Heidegger, Ser e Tempo, 2012, p.409

${ }^{59}$ Heidegger, Ser e Tempo, 2012, p.421

${ }^{60}$ Heidegger, Ser e Tempo, 2012, p.213
} 
que-compreende." ${ }^{61}$ Em outra passagem, "o ente só se torna acessível como ente se a compreensão-de-ser é; só se um ente do modo-de-ser do Dasein é, a compreensão-de-ser é possível como ente" ${ }^{\text {62 }}$.

Vai ficando cada vez mais claro a compreensão desta unidade ser-nomundo, Dasein-mundo e que acenamos para a unidade Visão-Manual. A partir dela poderíamos, talvez, pensar a relação Claridade-Apropriação. Heidegger mesmo afirma isso quando nos diz: "esse termo [visão] corresponde à claridade com que foi caracterizada a abertura do "aí" [...] ver que faz vir-ao-encontro o ente em si mesmo não-encoberto, que o torna acessível." ${ }^{\text {63 }}$ Em outra passagem ele novamente nos descreve:

[...] se deu o nome de clareira do Dasein à abertura do ser-em, na qual é pela primeira vez somente possível algo assim como a visão. A visão foi concebida em referência ao modo-fundamental de todo abrir do Dasein, isto é, o compreender, tomado no sentido da genuína apropriação [Zueignung] do ente em relação ao qual o Dasein pode se comportar conforme suas essenciais possibilidades-de-ser. ${ }^{64}$

O termo visão, respeitando a tradição da filosofia orientou-se e se orienta aqui como modo de acesso ao ente e ao ser. Haveria, talvez, uma herança da tradição que toma a visão para apreender, ou seja, do esclarecer, do trazer à luz, da claridade, do mostrar para que possa ser apreendido, descoberto, conhecido em sua totalidade. O próprio autor nos confirma sua herança ao dizer que "a tradição da filosofia orientou-se desde o início primariamente para o 'ver' como modo de acesso ao ente $e$ ao ser. Para salvaguardar a conexão com ela, a visão e o ver podem ser formalizados de modo tão amplo até que se obtenha um termo universal que caracterize em geral todo acesso a ente e ser." ${ }^{, 65}$

Vemos então que a unidade ser-no-mundo estaria intimamente relacionada à unidade Visão compreensiva-Manual. Na medida em que a compreensão que vê deixa o manual conjuntar-se, ela libera - abre - o manual para ser manual, em virtude de uma possibilidade do Dasein. Esta prévia abertura compreensiva se assenta imediatamente em um mundo, a partir do ente que vem ao encontro. Neste sentido, vemos que a compreensão se relaciona/abre um ente e vice-versa. Uma vez que compreender é o mesmo que existir, relação ao ser, e ser é sempre ser de um ente. "O caráter relacional dessas relações do remeter nós o apreendemos

\footnotetext{
${ }^{61}$ Heidegger, Ser e Tempo, 2012, p.423

${ }^{62}$ Heidegger, Ser e Tempo, 2012, p.589

${ }^{63}$ Heidegger, Ser e Tempo, 2012, p.417

${ }^{64}$ Heidegger, Ser e Tempo, 2012, p.479

${ }^{65}$ Heidegger, Ser e Tempo, 2012, p.479
} 
[fassen] como significar. [...] e o todo relacional desse significar, nós o denominamos significatividade." ${ }^{, 66} \mathrm{O}$ em-quê do compreender que se remete e que deixa o manual vir ao encontro no modo de ser da conjuntação é o fenômeno de Mundo. É onde o compreender se assenta, se familiariza, se dirige. Compreensão é compreensão de mundo. A estrutura deste é constituída pela totalidade significativa $^{67}$, que como vimos diz respeito ao caráter relacional do Dasein. A estrutura a que o Dasein se remete é o que Heidegger denomina de mundidade do mundo.

Neste momento fica claro o caráter de abertura ao ser necessário ao Dasein para que toda a estrutura ser-no-mundo possa ser descrita. Pensando esta abertura como um espaço ontológico propriamente dito, vemos que é nele e a partir dele que um ente ganha seu caráter de ser e o próprio Dasein humano também se determina nesta abertura. Tal espaço aberto pela compreensão do Dasein fundamenta o próprio ser deste ente e funciona como estrutura na qual o todo dos entes intramundanos ganham uma fundamentação de ser. O privilégio do Dasein está assentado, sobretudo, nesta abertura ao ser que desvela seu caráter existencial, sua compreensão que descobre todo ente-em-um-mundo. É neste sentido também que esta abertura ganha nome de morada e casa, com um eminnan-morada onde tudo acontece, seja a fundamentação do ente, de qualquer ente, inclusive o próprio Dasein, seja a possibilidade como possibilidade, como o novo que possibilita a quebra de um mundo sedimentado, da totalidadesignificativa, dos preconceitos hauridos e herdados de uma tradição histórica.

Este caráter remissivo-relacional dos entes, desde o Dasein até o ente para o qual ele se dirige, traz uma dinâmica e uma flexibilidade fundamentais. Quebram e destroem as teorias e visões substancialistas e coisificantes herdadas da tradição $^{68}$. Apresentando aos leitores outra maneira de não só encarar os entes com os quais lidamos a todo instante, mas sobretudo, outra maneira de lidar com o próprio Dasein. De que modo esta dinamicidade poderia ser importante no que diz respeito à própria relação com o que se compreende por ser humano? Existiria alguma mudança de postura? Esta mudança também se dá em meios relacionais

\footnotetext{
${ }^{66}$ Heidegger, Ser e Tempo, 2012, p.259

${ }^{67}$ Heidegger, Ser e Tempo, 2012, p.259

${ }^{68}$ Vale acentuar que Heidegger justamente após nos descrever a mundidade do Mundo do ser-nomundo nos apresenta o contraste do mundo de Descartes como extensio (Ser e Tempo, 2012, 265). "Por substância nada podemos compreender a não ser um ente tal que para ser não necessita de nenhum outro ente." (Adam- Tannery apud Heidegger).
} 
práticos? E aqui eu me refiro especificamente à psicologia clínica. Deixo tais perguntas em aberto.

De modo resumido, nas palavras do próprio autor temos:

O Dasein, como ser-no-mundo, já descobriu cada vez um "mundo". Essa descoberta fundada na mundidade do mundo foi caracterizada como pôr-o-enteem-liberdade relativamente a uma totalidade-de-conjuntação. $\mathrm{O}$ deixar conjuntar-se que põe-em-liberdade se efetua no modo de um remeter-se que circunvê, por sua vez fundado em uma prévia compreensão da significatividade. ${ }^{69}$

Neste deixar-ser a priori do Dasein ele põe em liberdade também os outros (parágrafo 26), que não vem ao encontro no modo da presença adiante da mão, nem da manualidade, mas do Dasein-com ${ }^{70}$, ente conforme-ao-Dasein, com os quais eu partilho o mundo. "O ser-em é ser-com ${ }^{71}$ com os outros [...] é ser-“aí"com". ${ }^{72}$ No ser-com os outros já foram abertos. Neste vir-ao-encontro o próprio Dasein pode "encontrar" a si mesmo. Tanto os outros como o si mesmo vem ao encontro a partir do manual de que se ocupa no mundo ${ }^{73}$.

O quarto capítulo se inaugura pela pergunta pelo quem do Dasein, que engloba o quem na cotidianidade, como vimos o modo de acesso a este ente que nós mesmos somos é a partir da cotidianidade cujo modo de ser se funda no sersi-mesmo impessoal. A resposta pelo quem é compreendida ontologicamente como aquilo que subjaz, como subjectum.

Este, como o mesmo em meio à multíplice alteridade, tem o caráter do si-mesmo. Embora se rejeite a ideia da substância-da-alma, do mesmo modo que a coisidade da consciência e a objectidade da pessoa, ainda se pode seguir interpretando o sujeito ontologicamente como algo cujo ser conserva, expressamente ou não, o sentido da presença adiante da mão. ${ }^{74}$

Nesta passagem, o leitor é levado a crer que Heidegger compreenderia o simesmo do Dasein como substância, no entanto, a partir daí, o autor alemão nos leva a pensar que talvez este modo mais imediato de responder pelo Dasein como um eu subjacente, fosse o mais forte e se desvendaria como o "oposto" do que parecia, como um "não eu”. É característico da analítica existencial apresentar o

\footnotetext{
${ }^{69}$ Heidegger, Ser e Tempo, 2012, p.321

70 "Empregamos o termo "Dasein-com" para a designação do ser em relação ao qual os outros entes são deixados-em-liberdade no interior-do-mundo.”( Ser e Tempo, 2012, p.347) O Daseincom é Dasein dos outros - o Dasein é posto em liberdade pelo mundo de um ser-com (Ser e Tempo, 2012, p.349). O mundo dá liberdade ao ente e ao Dasein (Ser e Tempo, 2012, p.335)

${ }^{71} \mathrm{O}$ ser-com possuiria em Heidegger um sentido ontológico-existencial. Subsistiria mesmo quando um outro Dasein não é percebido (Ser e Tempo, 2012, p.349)."Na medida em que o Dasein é, tem ele o modo-de-ser do ser-um-com-o-outro."(Ser e Tempo, 2012, p.361)

${ }^{72}$ Heidegger, Ser e Tempo, 2012, p.345

${ }^{73}$ Heidegger, Ser e Tempo, 2012, p.345-347

${ }^{74}$ Heidegger, Ser e Tempo, 2012, p.333
} 
mais imediato - a lida cotidiana - para mostrar que tal comportamento tendencioso, seria talvez, sustentado por uma instância mais originária, tal duplicidade se revela na relação próprio-impróprio sempre em jogo nesta obra. Neste caso, o eu subjacente (perda do si-mesmo, não-eu, impróprio) se mostraria como o mais imediato, mas mais originário que ele seria um si-mesmo próprio. Deste modo, o "eu" se desvendaria na cotidianidade como a perda-de-si-mesmo. Este "eu" deve ser interpretado existenciariamente. Uma vez que existindo, o Dasein é cada vez seu si-mesmo, eu sou o que cada vez o Dasein é. Neste simesmo do Dasein haveria ainda uma constância (Ständigkeit) e uma não constância $^{75}$. Sobre esta constância Heidegger nos adverte: ela "não concerne à contínua presença adiante da mão de algo, mas ao modo-de-ser do Dasein como ser-com." 76 Nos caracteres do cotidiano ser-um-com-o-outro reside esta constância do Dasein, em um si-mesmo impróprio ${ }^{77}$. Em Seminários de Zollikon, Heidegger nos esclarece quanto a esta constância do si-mesmo.

"O si-mesmo" é aquilo que em todo o caminho histórico do meu Dasein se mantém constantemente o mesmo, justamente no modo do ser-no-mundo, do poder-ser-nomundo. O si-mesmo nunca está presente como substância. A constância do simesmo é singular no sentido de que o si-mesmo pode sempre voltar para si mesmo e sempre se encontra em sua morada como o mesmo. A constância de uma substância só consiste no fato de que ela está sempre presente no decorrer do tempo, mas nada tem a ver com o próprio tempo. A constância do si-mesmo é em si 'temporal', isto é, se temporaliza. Esta mesmidade do Dasein é somente no modo da temporalização. ${ }^{78}$

Esta constância do si mesmo que não está presente como substância, uma vez que se temporaliza, possui uma volta para si mesmo e sempre se encontra em sua morada. Que morada seria essa? Para a qual sempre se volta, para o simesmo? Parece existir certo ponto de apoio, como talvez, um ponto arquimediano para o qual se volta, o si-mesmo, mas que, ao mesmo tempo se temporaliza, pois não se mantém atemporal, presente a si, como algo substancial. Mas seria um "ponto" que se temporaliza, que volta sobre si e que sempre se encontra em sua morada com este mesmo. A morada e o mesmo sempre se dão, mas no modo da temporalização. Este mesmo pode se dar de modo próprio ou impróprio (de modo cotidiano). O mesmo responde pelo quem e só pode ser acessado adequadamente

\footnotetext{
${ }^{75}$ Heidegger, Ser e Tempo, 2012, p.339

${ }^{76}$ Heidegger, Ser e Tempo, 2012, p.369

${ }^{77}$ Heidegger, Ser e Tempo, 2012, p.369 e p.371

${ }^{78}$ Heidegger, Seminários de zollikon [Diálogos com Medard Boss], 2001, p.194
} 
a partir da questão ontológico-existencial ${ }^{79}$. O si mesmo próprio seria acessado a partir da remoção dos encobrimentos cotidianos. Sem o cotidiano me mantenho ainda o mesmo? Um mesmo próprio na morada que agora não estaria mais totalmente absorvido pelas determinações cotidianas. O que sobra deste mesmo? Desta morada? Sobra a abertura ao ser como modo de ser essencial do Dasein como Ser-em.

Vimos que o Dasein com os entes que vem ao encontro, ele se ocupa (Besorge), com os Dasein-com ele se preocupa (Fürsorge). Estes são modos de ser do ser do Dasein que Heidegger chamou de cuidado (Sorge). O autor busca, em toda sua obra Ser e tempo, interpretar o Dasein em sua imediatidade, em sua cotidianidade mediana, em seu na maior parte das vezes. Tal imediatidade faz parte da constituição positiva do Dasein chamada imprópria. Isso significa que na maior parte das vezes, ele está perdido de si mesmo, de modo impróprio. Heidegger nos mostra que toda sua cotidianidade revela o modo de ser ôntico do Dasein, no qual ele se encontra mais próximo no seu dia a dia, e no qual estamos na maior parte das vezes, enquanto o mais distante é o ontológico, o próprio. Vimos que a resposta pelo quem do Dasein levava a uma instância denominada ser-com própria. Este modo de ser próprio estaria oculto para o Dasein, possuindo o caráter de distanciamento. Como responderíamos então pelo quem mais próximo? O quem mais próximo é o impróprio derivado do ser-com, que Heidegger denominou impessoal (Das man). Onde ele não é si-mesmo próprio, pois os outros the retiraram o ser. Dispondo sobre as cotidianas possibilidades de ser do Dasein, "os outros" encobrem sua essência e permanecem neutros ${ }^{80}$. Eles não têm um nome próprio, "não é ninguém determinado e que todos são, não como soma, porém, [prescrevendo] o modo-de-ser da cotidianidade." 81 "É o ninguém ao qual todo Dasein já se entregou. ${ }^{„ 82}$ Tal impessoal possui o caráter da mediania cotidiana que nivela todas as possibilidades de ser, insensível às diferenças e à autenticidade, aliviando-o de modo a retirar do Dasein sua responsabilidade, que só poderá ser adquirida mediante a conquista da essência própria de si mesmo. Apesar do impessoal possuir características que distanciam o Dasein de seu si-mesmo próprio, ele faz parte de sua constituição positiva, ou

\footnotetext{
${ }^{79}$ Heidegger, Ser e Tempo, 2012, p.339

${ }^{80}$ Heidegger, Ser e Tempo, 2012, p.363-364

${ }^{81}$ Heidegger, Ser e Tempo, 2012, p.364

${ }^{82}$ Heidegger, Ser e Tempo, 2012, p.367
} 
seja, é o Dasein cotidiano que articula o contexto de remissão da significatividade. De modo que

o mundo do Dasein dá liberdade ao ente que vem-ao-encontro para uma totalidadede-conjunção que é familiar ao impessoal e cujos limites a mediania do impessoal estabelece. De imediato o Dasein factual está no mundo-com medianamente descoberto. De imediato eu não "sou" "eu", no sentido do si-mesmo próprio, mas sou os outros no modo do impessoal. ${ }^{83}$

O próprio seria aquele que descobriria o mundo propriamente, removendo os encobrimentos e quebrando as contrafações com que o Dasein se fecha para si mesmo. Como podemos ver, o caráter de propriedade do Dasein acena para uma abertura a um fechamento característico do impróprio. No entanto, se engana aquele que pensa que o Dasein próprio abandona por completo sua impropriedade. O que acontece é uma modificação existencial do impessoal como um existencial essencial. O mais próprio possuiria o caráter de não-ser-fechado $\left[\right.$ de aberto] ${ }^{84}$.

Heidegger passa a primeira parte de Ser e tempo tentando apresentar os elementos estruturais do Dasein para mostrar de modo adequado a estrutura do todo deste fenômeno unitário. Para descrever este todo o autor retoma o caráter existencial do Dasein para apresentar seu caráter de abertura, onde ele acontece como ser-no-mundo. É justamente no parágrafo 28 intitulado A tarefa de uma análise temática do ser-em, e início do quinto capítulo - O ser-em como tal, que Heidegger começará a descrever o que se compreende por Da (aí) de um Da-sein (ser-aí). O capítulo é inteiramente dedicado à descrição do ser do "aí", que veremos como a abertura ao ser do ser-em, como espaço de abertura ontológica compreensiva do Dasein. "Só enquanto o Dasein é, isto é, enquanto possibilidade

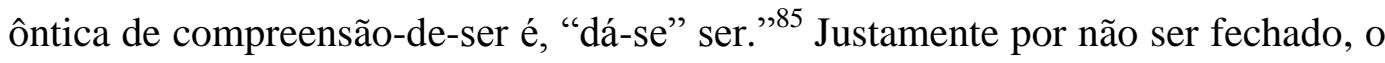
Dasein é marcado por esta abertura originária que podemos compreender como espacialidade existencial-ontológica, uma abertura ao ser do ente, característica do ser-em. "O termo "aí" significa essa essencial abertura. Por meio dela esse ente (o Dasein) é para ele mesmo "aí", unido com o ser- "aí" de mundo." 86 É no aí - na abertura - que une-se o ser "aí" de mundo e o Dasein. Um espaço onde ambos coconstituem. "Existindo, o Dasein é o seu "aí”, o que significa, assim: o mundo é

\footnotetext{
${ }^{83}$ Heidegger, Ser e Tempo, 2012, p.371

${ }^{84}$ Heidegger, Ser e Tempo, 2012, p.379

${ }^{85}$ Heidegger, Ser e Tempo, 2012, p.589

${ }^{86}$ Heidegger, Ser e Tempo, 2012, p.380-381
} 
"aí"; o seu ser- "aí" é o ser-em." ${ }^{87}$ O Dasein traz de casa esta abertura - o seu ai ${ }^{88}$. Será que poderíamos pensar a partir desta afirmação de Heidegger que em primeiro lugar há o aí, a abertura a partir da qual o Dasein estaria para ele mesmo e estaria unido com o ser aberto do mundo? A morada é a abertura, o ser-em é a abertura, o que há é a abertura (ao ser dos entes e de si mesmo). O que há seria esta casa, morada - em - como abertura ontológica onde todos os entes vem ao encontro. Esta abertura conteria em si uma iluminação (claridade), onde o Dasein é iluminado, ele $[$ Dasein $]$ é claridade da clareira ${ }^{89}\left[\right.$ Lichtung $^{90}$, ainda que não a produza. Existencialmente, o Dasein é sua abertura, está na abertura, no fora, tem de ser sua abertura, existindo, ele está no aberto. A abertura do ser-em se mostra como a clareira [Lichtung] do Dasein ${ }^{91}$. Com intuito de aprofundar-se nesta abertura, Heidegger seguirá os capítulos seguintes nos apresentando os dois modos possíveis de abertura do ser-em, do ser do "aí", da abertura do Dasein, o próprio e o impróprio, o ôntico e o ontológico. O espaço existencial de abertura do Dasein (ser-aí) é ôntico-ontológico, uma vez que o próprio Dasein em seu movimento existencial é marcado por uma diferença ôntico-ontológica. Se em Ser e Tempo Heidegger não escreveu explicitamente que o Dasein como compreensão de ser dizia respeito à diferença ontológica, em $O$ problema da transcendência e $O$ problema de Ser e Tempo (1928), conferência um ano depois da publicação de Ser e tempo, ele nos deixa isso claro e explícito:

O ser é diferente do ente - e, em termos absolutos, só esta diferença (Unterschied), esta possibilidade de diferença, proporciona uma compreensão de ser. Dito de outra maneira: na compreensão de ser reside o levar a cabo esta diferenciação de ser e ente. Esta diferença é a que acima de tudo possibilita algo assim como a ontologia. Daí que denominamos esta diferença que acima de tudo possibilita algo assim como a compreensão de ser, a diferença ontológica (ontologische Differenz). ${ }^{92}$

No modo de abertura próprio nós temos três instâncias fundamentais: $a$ disposição, a compreensão e o discurso. E no modo impróprio, outras três: $o$ falatório, a curiosidade e a ambiguidade que formam o que se compreende pela decadência. Faremos uma breve descrição destes elementos, apenas para

\footnotetext{
${ }^{87}$ Heidegger, Ser e Tempo, 2012, p.407

${ }^{88}$ Heidegger, Ser e Tempo, 2012, p.381 2

${ }^{89}$ Esta clareira e este espaço tem uma íntima relação com a verdade, Heidegger, Ser e Tempo, 2012, p.381 [nota de rodapé].

${ }^{90}$ Heidegger, Ser e Tempo, 2012, p.381

${ }^{91}$ Heidegger, Ser e Tempo, 2012, p.479

${ }^{92}$ Heidegger, El problema de la transcendencia y el problema de Ser y tiempo [§10] In. Princípios metafísicos de la lógica, 2007, p.178 [Com exceção das referências aos textos publicados em português, todas as traduções aqui são minhas]
} 
situarmos e familiarizarmos o leitor com estes termos e podermos adentrar a possibilidade de desvelamento desta abertura para o próprio Dasein e a apropriação desta abertura como cuidado.

A disposição (Befindlichkeit) nos fala de um estado de ânimo (stimmung), de certa tonalidade na qual nos encontramos. É um como estamos, é ela que é responsável pela absorção do Dasein-em-um-mundo. Lançado na abertura, no “aí", entregue à responsabilidade de seu ser, o Dasein se encontra "aî" não como uma busca, mas como uma fuga. Este lançado/jogado revela a facticidade na qual nós sempre nos encontramos. A disposição é repentina e abrupta, abrindo o Dasein de maneira total como ser-no-mundo. "A tonalidade afetiva já abriu cada vez o ser-no-mundo como um todo e torna possível pela primeira vez um direcionar-se para ..."93 A disposição é responsável por esta prévia abertura do mundo do ser-em. Conforme a tonalidade, o como nos encontramos, o manual se mostrará a cada vez diferente ${ }^{94}$. Heidegger descreve esta imediatidade pela qual somos tomados de modo claro numa passagem acerca da tristeza.

Uma tristeza se abate sobre um homem com o qual convivemos. Será que tudo se dá apenas de um modo tal que este homem possui um estado relativo a uma vivência? Afora isto, tudo permanece como antes? Ou o que acontece aqui? O homem que se tornou triste se fecha, se torna inacessível, sem com isto ser rude para conosco. Somente isto se dá: ele se torna inacessível. Não obstante, estamos juntos dele como antes. Talvez passemos mesmo a encontrá-lo ainda mais frequentemente e venhamos mais ao seu encontro; ele também não altera nada em seu comportamento com as coisas e conosco. Tudo está como antes, e, porém, tudo está diverso. Não apenas sob este ou aquele aspecto, mas, sem prejuízo do caráter próprio ao que fazemos e no que nos inserimos, o como, no qual estamos, é diverso. ${ }^{95}$

A tonalidade afetiva tem o caráter de uma afetação na qual nós sempre nos encontramos. "O fazer vir ao encontro da ocupação da circunvisão tem o caráter de um ser-afetado [...] pela disposição. ${ }^{96}$ Deste modo, a disposição característica desta abertura própria tem o caráter de uma afetação. Em outra passagem o autor nos descreve: "na disposição reside existenciariamente um abridor ser-referido ao mundo, a partir do qual o afetante pode vir ao encontro." ${ }^{\text {97 }}$ Tal afetabilidade não só faz parte da abertura do Dasein a partir da disposição, mas também pertence à própria questionabilidade deste ente como modo de existir. Já nas primeiras

\footnotetext{
${ }^{93}$ Heidegger, Ser e Tempo, 2012, p.391 [Grifado nosso]

${ }^{94}$ Heidegger, Ser e Tempo, 2012, p.395

${ }^{95}$ Heidegger, Conceitos fundamentais da metafísica (1929/2006), p.79

${ }^{96}$ Heidegger, Ser e Tempo, 2012, p.393

${ }^{97}$ Heidegger, Ser e Tempo, 2012, p.393
} 
páginas de Ser e tempo, Heidegger nos descreve: "a essencial afetabilidade do perguntar [modo de ser do Dasein] por seu perguntando [Ser] pertence ao sentido mais próprio da questão-do-ser." ${ }^{98} \mathrm{O}$ Dasein é a priori um ser afetado por. O Dasein é aberto para, em se questionando como ser afetado. Nestas passagens, poderíamos dizer que é o ser do que vem ao encontro (o ente) que nos afeta. $\mathrm{O}$ Dasein é esta abertura afetada por, na medida em que ele é um ente cuja indeterminabilidade é marca constitutiva. Neste sentido ele se deixa ser afetado, ele tem que se deixar, para poder ser, para poder se determinar. A disposição seria a tonalidade abrupta cuja característica é a afetação e que toma o ser do Dasein a partir de um modo de ser característico do mundo dele.

Resumidamente, as três características principais da disposição são: abrir o Dasein como lançado-em-um-mundo, abrir o todo do ser-no-mundo e abrir o serafetado por um vir-ao-encontro na ocupação circunvisiva. Agora fica um pouco mais clara a fuga que Heidegger apontava como característica da disposição. Ela é o modo de ser em que o Dasein se deixa afetar pelo mundo, ele vai em direção ao mundo, se deixa absorver pelo mundo, afetar-se no mundo, esquivando-se (fugindo) de algo. Veremos mais adiante esta fuga e este algo do qual o Dasein foge.

Outra característica da abertura do Dasein é a compreensão de ser, que como vimos é uma das principais características para compreender a analítica existencial. No em virtude de o Dasein se abre como compreensão, neste em virtude de compreensivo é coaberto a significatividade que nele se funda. "A abertura do compreender, como abertura do em virtude de e da significatividade, é cooriginariamente abertura do completo ser-no-mundo." ${ }^{99}$ É neste compreender que reside o caráter de poder-ser do Dasein. O Dasein é um ser-possível, de ponta a ponta uma responsabilidade lançada, entregue à responsabilidade de si mesmo ${ }^{100}$. O compreender abre o que lhe toca ${ }^{101}$, o que lhe afeta, projetando sobre o em virtude de e sobre a significatividade do que é cada vez seu mundo. Lançado, o Dasein é no modo-de-ser do projetar. É interessante como Heidegger dá ao Dasein este caráter de contínuo lançamento e projeto, de modo que, estamos sempre nos fazendo, nos projetando em possibilidades em virtude das quais nós

\footnotetext{
${ }^{98}$ Heidegger, Ser e Tempo, 2012, p.49

${ }^{99}$ Heidegger, Ser e Tempo, 2012, p.407

${ }^{100}$ Heidegger, Ser e Tempo, 2012, p.409

${ }^{101}$ Heidegger, Ser e Tempo, 2012, p.411
} 
somos. Tal característica foi fundamental para repensar o humano, não mais determinado quididativamente, mas existindo em modos de ser possíveis, jogado em-um-mundo. Esta quebra de determinações dadas ao sujeito será base para o discurso da psicologia Daseinsanalítica ${ }^{102}$.

Heidegger chamou interpretação (Auslegung) o desenvolvimento do compreender. "Na interpretação, o compreender, compreendendo apropria-se do seu compreendido," 103 de modo que as possibilidades projetadas no compreender são elaboradas. $\mathrm{O}$ interpretado interpreta o expressamente compreendido que tem a estrutura do algo como algo. Ao perguntar sobre o compreendido, responde-se: é para... Este, por sua vez, se mostra como seu "como quê", esta é a estrutura do ser-expresso de um compreendido que constitui a interpretação. O como expresso numa interpretação compreensiva é originário na estrutura de abertura do Dasein. Heidegger pede atenção para que não tomemos a interpretação como uma instância que veste uma presença adiante da mão, dizendo arbitrariamente o que ela é ou deixa de ser, mas põe à mostra o ente que vem ao encontro a partir de uma totalidade conjuntativa. Toda interpretação se moveria num prévio compreensivo, caracterizado pela estrutura existencial do prévio do Dasein. Nesse sentido, Heidegger nos pergunta: como produzir resultados científicos, se estaríamos presos em um círculo prévio interpretativo? Evitar o círculo seria pensar num conhecimento histórico que conseguisse recomeçar do zero, evitando o círculo e criando um saber independente. O que seria impossível. Dessa forma, ele responde que tentar evitar o círculo ou sair do círculo, seria compreendê-lo mal, "o decisivo não é sair do círculo, mas nele penetrar de modo correto [rechten]." ${ }^{104}$ A maneira positiva de adentrar neste círculo é não deixar que o prévio seja dado por ocorrência e conceitos populares, mas se assegurar do tema científico mediante a elaboração a partir das coisas elas mesmas ${ }^{105}$.

$\mathrm{O}$ círculo prévio interpretativo diz respeito à própria hermenêutica do Dasein, ao horizonte histórico no qual este ente compreende sentidos de ser. $\mathrm{Na}$ maior parte das vezes estamos imersos num horizonte histórico sedimentado

\footnotetext{
${ }^{102}$ Nós não temos como objetivo descrever a Daseinsanálise, linha da psicologia que tem por base a analítica existencial do Dasein. Veja Dastur, F. e Cabestan, P. Daseinsanalyse: phénoménologie et psychiatrie, Paris: J. vrin, 2011 e em português Dastur, F. e Cabestan, P. Daseinsanalise: fenomenologia e psicanálise, 2015.

${ }^{103}$ Heidegger, Ser e Tempo, 2012, p.421

${ }^{104}$ Heidegger, Ser e Tempo, 2012, p.433

${ }^{105}$ Heidegger, Ser e Tempo, 2012, p.433
} 
(impróprio), ou seja, num círculo prévio interpretativo a partir do qual algo se mostra como algo. Como vimos sair deste círculo é algo que não faria qualquer sentido, é começar a história do zero, o que Heidegger aponta é a possibilidade de entrar de modo correto nele, compreendendo as coisas elas mesmas, seus sentidos originários, abrindo espaço, assim, para outros modos de ser. "O 'círculo' na compreensão pertence à estrutura do sentido," 106 que tem suas raízes no compreender interpretante.

Sentido (Sinn) seria aquilo que articula no abrir que compreende, "é aquilo em-relação-a-quê do projeto, estruturado pelo ter-prévio, pelo ver-prévio e pelo conceito-prévio, a partir de que algo pode ser compreendido como algo."107 O privilégio do Dasein estaria justamente em seu modo de existir, compreendendo sentido, pois só este ente tem sentido, projeta sentido de ser. "Só o Dasein tem sentido, na medida em que a abertura do ser-no-mundo 'pode ser preenchida' pelo ente que nele pode ser descoberto." O sentido é justamente o que sustenta as ações e comportamentos do Dasein, que "preenche" sua abertura e dá base à unidade ser-no-mundo, visão-manual, claridade-apropriação. Sem os sentidos o Dasein não agiria, não se comportaria e nada "preencheria" tal abertura. Ele não está por trás do ser como fundamento, mas ao perguntar pelo sentido, pergunta-se sobre o próprio ser, é ele mesmo que responde pelo ser, pois se encontra na compreensibilidade-projetiva do Dasein. "O "fundamento" só é acessível como sentido, mesmo que ele mesmo seja o abismo da falta-de-sentido."108

O terceiro elemento da abertura do Dasein é o discurso (Rede) como a articulação da compreensibilidade, fundamentando o que se compreende por interpretação e enunciação ${ }^{109}$. O articulado originariamente na interpretação e mais originariamente no discurso é o sentido. De modo que o articulado no discurso é o significado que é sempre provido de sentido, o discurso acontece como articulação significante da compreensibilidade do dispor-se no ser-nomundo. A linguagem aparece como o ser-expresso do discurso. E como fala, característica do discurso, pertence o ouvir e o calar. De maneira nenhuma este discurso diz respeito apenas à linguagem fonética, mas toda significação

\footnotetext{
${ }^{106}$ Heidegger, Ser e Tempo, 2012, p.435

${ }^{107}$ Heidegger, Ser e Tempo, 2012, p.429

${ }^{108}$ Heidegger, Ser e Tempo, 2012, p.431

${ }^{109}$ Modo derivado da interpretação funciona como um quê determinante da presença adiante da mão, modificando o como originário da interpretação compreensiva - hermenêutica.
} 
articulada (por um sentido) é discurso. O ouvir do discurso é fundamental para a apropriação do si mesmo do Dasein. Nas palavras do autor, "para o discurso o ouvir é constitutivo [...] o ouvir constitui inclusive o estar-aberto primário e autêntico do Dasein para o seu poder-ser mais próprio, como um ouvir a voz do amigo que cada Dasein traz junto de si." ${ }^{, 110} \mathrm{O}$ ouvir e o discorrer se fundam no compreender assim como o calar-se, como possibilidade do discorrer autêntico, derruba o falatório impróprio, trazendo a possibilidade de ouvir o amigo que o Dasein traz junto de si e a transparência (visão própria ${ }^{111}$ ) do ser-um-com-outro.

Voltando ao fio condutor da cotidianidade proposto por Heidegger, vamos descrever agora a abertura do modo cotidiano que deve ser interpretada como um fenômeno positivo do ser-no-mundo e possui ainda três instâncias que vão fundar o que Heidegger denominou o fenômeno da decadência.

Como característica do impessoal cotidiano apontamos a fuga de si-mesmo para a perda-de-si-mesmo, bem como um nivelamento mediano. Para compreendermos melhor esta fuga de si mesmo, precisamos descrever o que acontece na perda-do-si-mesmo, assim compreenderemos esta perda que é para onde a fuga se dirige. No falatório (Gerede), primeira instância, o dito, que não se limita a oralidade, é compreendido por todos na mesma mediania valendo apenas que se discorra, difundindo e repetindo o discorrido, sem qualquer apropriação originária dos entes. Fala-se o que todo mundo fala e reproduz o que já está sedimentado. Se mostrando deste modo como um fechamento do ser-si-mesmo e um impedimento do novo. A curiosidade (Neugier) por sua vez, se mostra como segunda instância, e tem como modo a visão característica da cotidianidade. Vimos que a circunvisão é o modo de ver da ocupação, que quando termina o que fazia nem por isso desaparece. A circunvisão fica livre e neste repousar ela busca para si novas possibilidades, não para compreender a relação de ser com o visto, mas para manter-se neste ver como uma incapacidade de permanecer no imediato, inquietando-se, excitando-se, distraindo-se sempre com o novo. Estas características cotidianas impróprias do discurso e da visão desenraizam o Dasein de seu si-mesmo e o absorvem numa perda-de-si-mesmo. De modo que "a

\footnotetext{
${ }^{110}$ Heidegger, Ser e Tempo, 2012, p.461

111 "A visão primariamente relativa à existência e no todo, nós a denominamos a transparência." (Heidegger, Ser e Tempo, 2012, p.417) Transparência diria respeito a uma visão de si mesmo, de sua existência como um todo, enquanto a não transparência estaria relacionada à não compreensão de si como ser-no-mundo.
} 
curiosidade, para a qual nada está fechado, e o falatório, para o qual nada fica sem ser compreendido, [...], dão ao Dasein [...] a garantia de uma 'vida' pretensamente 'vivida'." "112 A terceira característica desta abertura imprópria seria a ambiguidade (Zweideutigkeit), onde tudo parece autenticamente compreendido, mas no fundo não o é, ou não parece, mas no fundo é. Tudo já foi rastreado e suspeitado, como num rastro do que já foi dito, sem no fundo nada dizer. Tudo ocorre e no fundo nada acontece.

Estas três características, brevemente descritas, dizem respeito ao caráter de lançado do Dasein, sua conexão se dá sobre o modo de ser da cotidianidade que Heidegger denominou decadência. Este modo de ser é o mais imediato onde o Dasein está tomado pelo "mundo", mas não significa de modo algum, e Heidegger deixa isso claro em diversos momentos, uma queda de um lugar mais puro. A decadência faz parte do modo como sempre nos encontramos de início e na maioria das vezes. Neste modo, o Dasein se fecha num círculo que se auto atrai, ou seja, sua mobilidade fica como que num redemoinho ${ }^{113}$ impróprio sem se dar conta de suas possibilidades mais próprias. Esta auto atração da cotidianidade por si mesma, vai revelar a fuga e a esquivança característica do lançado. Lançado na cotidianidade o Dasein de início e na maioria das vezes se mantém. Mas o que ocorre que ele se mantém aí? E do que exatamente ele foge?

Chegamos agora ao sexto capítulo no qual fecharemos a primeira sessão da primeira parte de sua obra. Justamente neste ponto Heidegger começará a conectar todos os elementos apresentados buscando a totalidade do todo-estrutural a partir de um olhar fenomenológico unitário $^{114}$. O autor, então se pergunta se haveria nesta abertura que vamos descrever um modo no qual o Dasein estaria aberto para ele mesmo em seu ser, uma disposição compreensiva em que ele ficasse aberto para ele mesmo de um modo privilegiado. Seu objetivo, ele deixa claro: "se a analítica existencial do Dasein deve manter sua função ontológico fundamental, numa clareza de princípio, então para levar a cabo a tarefa prévia de pôr a mostra o ser do Dasein, a analítica deve buscar uma das mais amplas e originárias possibilidades de-abertura que residem no Dasein ele mesmo."115 São três objetivos que se interligam: a função ontológico fundamental da

\footnotetext{
${ }^{112}$ Heidegger, Ser e Tempo, 2012, p.487

${ }^{113}$ Heidegger, Ser e Tempo, 2012, p.501

${ }^{114}$ Heidegger, Ser e Tempo, 2012, p.507

${ }^{115}$ Heidegger, Ser e Tempo, 2012, p.511
} 
analítica; por a mostra o ser do Dasein e buscar uma abertura ampla e originária do Dasein. Deste modo a ampla abertura do Dasein poderia desvelar seu ser como abertura ao ser, levando a analítica deste ente a conquistar sua função ontológico fundamental, nos preparando para a problemática da pergunta pelo sentido de ser em geral ${ }^{116}$. Neste sentido, Heidegger vai recorrer à angústia como uma tonalidade afetiva da disposição que satisfaz a tais exigências de método. Ela fornecerá a originária totalidade-de-ser do Dasein cujo ser se desvendará como Cuidado (Sorge). A raridade da angústia, porém, não retira sua aptidão para assumir uma função metódica fundamental na analítica existencial ${ }^{117}$.

Como vimos na cotidianidade decadente o Dasein foge de si mesmo, de seu poder-ser mais próprio em direção à absorção do mundo. Esse desviar leva para longe do Dasein, de um Dasein próprio ontológico - e por isso, distante. O desvio vai em direção a um Dasein impróprio ôntico - próximo. É só posto diante de si mesmo que se pode fugir de si mesmo. "No decair, é de si mesmo que o Dasein se desvia." 118 Se desvia em direção ao ente no mundo cotidiano impróprio. O que tem neste si mesmo que faz com que o Dasein se desvie em direção ao ente no mundo? Este si mesmo é marcado pela angústia que vai fundar a decadência e o próprio movimento em direção ao ente. Ela fundaria o próprio caráter de afetação deste ente, visto que sem ela, o Dasein, talvez, não se deixaria afetar pelos entes. Ela revela o completamente indeterminado do Dasein, como um estranhamento, pois não se sabe bem o que acontece quando a angústia nos toma. Este estranhamento Heidegger descreve como um não-estar-em-casa (ser-em aberto) que persegue o Dasein ameaçando a perda de sua cotidianidade (seu estar-emcasa). O não ser-em-casa, estranho, indeterminado, angustiante (e ontológico) foge para a familiar absorção dos entes no mundo, para um sentir-se em casa do ser-em decaído (ôntico). O não ser-em-casa expropriado se revela como o modo de ser-em mais originário. Uma vez que o ontológico é mais originário. O Dasein precisa desta estranheza originária para se lançar junto aos entes. E por isso, a angústia é fundadora da decadência.

Tomado pela disposição da angústia, diante do indeterminado angustiante de si mesmo, o Dasein já está distanciado do mundo (total não-significatividade),

\footnotetext{
${ }^{116}$ Heidegger, Ser e Tempo, 2012, p.513

${ }^{117}$ Heidegger, Ser e Tempo, 2012, p.533

${ }^{118}$ Heidegger, Ser e Tempo, 2012, p.519
} 
nenhum ente se liga ao projeto existencial do Dasein, de modo que o que se perde é esta ligadura, esta articulação com o mundo - o sentido. $\mathrm{O}$ ameaçador que se mostra na angústia não está em parte alguma, revelando a própria “abertura de mundo em geral para o ser-em essencialmente espacial"119. O que sobra é a própria imposição do mundo como mundo. A angústia ${ }^{120}$ isola o Dasein ${ }^{121}$ retirando-o da possibilidade de se compreender a partir do mundo cotidiano decadente, ela o mantem como ser-possível, aberto à, um ser-em como poder-ser isolado, puro, lançado, aberto ${ }^{122}$. E justamente aí, isolado, ele abre a possibilidade de seu poder-ser mais próprio "o ser livre para a liberdade do-a-si-mesmo seescolher e se-possuir" ${ }^{123}$. É por isso, que o Dasein busca refúgio nos entes. Sem eles, ou melhor, sem o sentido que compreende ser de um ente, o Dasein se mantém isolado. Num solipsismo, não ausente de mundo, mas que traz o mundo para diante de si, revelando-o como ser-no-mundo. Tal isolamento é justamente o que vai permitir a revelação de sua totalidade, sua unidade existencial como serno-mundo. É quando a abertura se revela que o ser-no-mundo tem a possibilidade de se apreender como um todo. A possibilidade de apreender-se como ser-no-mundo é a apreensão de todas as estruturas existenciais descritas até agora que têm seu centro na abertura $^{124}$ ao ser.

O fenômeno da angústia revelou uma ampla e originária abertura do Dasein, mostrando-o como uma unidade total existente, um ser-no-mundo que lançado decai. Tais caracteres: existencialidade, facticidade e decadência vão revelar o todo do Dasein. Estes elementos não funcionam como uma sobreposição de determinações, mas possuem uma conexão originária que as une em uma unidade de ser. A existencialidade revela que o Dasein em seu ser já é, cada vez, antecipado em relação a si mesmo, estando para além de si, em jogo com o seu

\footnotetext{
${ }^{119}$ Heidegger, Ser e Tempo, 2012, p.523

120 “O caráter de indeterminação daquilo diante de e por que nos angustiamos, contudo, não é apenas uma simples falta de determinação, mas a essencial impossibilidade de determinação.” A respeito da indiferença e da estranheza acerca do modo como nos encontramos abatidos pela angústia, Heidegger nos descreve: "Este afastar-se do ente em sua totalidade, que nos assedia na angústia, nos oprime. Não resta nenhum apoio. Só resta e nos sobrevém - na fuga do ente - este nenhum. A angústia manifesta o nada. [...] a angústia nos suspende porque ela põe em fuga o ente em sua totalidade. Nisto consiste o fato de nós próprios - os homens que somos - refugiarmo-nos no seio dos entes." (Heidegger, Que é metafísica? 1929/1973, p.237) A angústia "emudece qualquer dicção do "é”." (Heidegger, Que é metafísica? 1929/1973, p.238)

${ }^{121}$ Heidegger, Ser e Tempo, 2012, p.525

${ }^{122}$ Heidegger, Ser e Tempo, 2012, p.527

${ }^{123}$ Heidegger, Ser e Tempo, 2012, p.527

${ }^{124}$ Heidegger, Ser e Tempo, 2012, p.639
} 
ser, tendo que ser a cada vez o ser que é seu. Mas “a existencialidade é essencialmente determinada pela facticidade." ${ }^{125}$ Todo ser-aí existe-em-ummundo, o Dasein está entregue a si mesmo, lançado em um mundo (facticidade), como ser-no-mundo. Vimos que o abandono em relação a si está intimamente relacionado ao fenômeno da angústia. É diante do próprio ser-no-mundo aberto pelo fenômeno da angústia em sua totalidade, que o ser-aí se deixa absorver por mundo. $\mathrm{O}$ fenômeno da angústia revela nada menos que a indeterminação deste ente que nós mesmos somos. O Dasein sempre existe-já-sendo-em. Neste em-ummundo o Dasein já está sempre absorvido nos modos da ocupação e preocupação da cotidianidade decadente. Deste modo: o ser do Dasein significa cuidado: "serantecipado-em-relação-a-si-em (-o-mundo) como ser-junto- (ao-ente-do-interiordo-mundo que vem-ao-encontro)" ${ }^{126} \mathrm{O}$ cuidado como totalidade estrutural originária, como unidade de ser do Dasein está em todo e cada comportamento deste ser, funciona como um "a priori" de sua constituição de ser, "anterior" a todo comportamento e pressuposição do Dasein ${ }^{127}$.

A 'universalidade' transcendental do fenômeno do cuidado e de todos os existenciais fundamentais tem, por outro lado, aquela amplitude exigida para que se torne já-dado o solo sobre o qual se move toda interpretação-do-Dasein que seja uma ôntica visão-do-mundo, em que ele se compreende ou como "preocupação-da-vida" (Lebensorge) e indigência ou em um sentido oposto. ${ }^{128}$

Neste ponto de sua obra, Heidegger nos questiona o que sustenta esta unidade total (o cuidado)? ${ }^{129}$

A interpretação ontológica originária deve assegurar-se de trazer o todo do ente temático para o campo prévio - hermenêutico - a partir do qual uma interpretação é possível. É a partir deste campo hermenêutico prévio que todas as estruturas de ser devem ser postas em relevo garantindo a segurança fenomênica. Tal garantia só poderá ser dada a partir do poder-ser próprio que dará originariedade à interpretação existencial, ou seja, garantirá a interpretação das coisas elas mesmas ${ }^{130}$. Esta propriedade acena para a correta entrada no círculo já apontada anteriormente.

Para que possamos compreender a totalidade unitária do Dasein e nos

\footnotetext{
${ }^{125}$ Heidegger, Ser e Tempo, 2012, p.537

${ }^{126}$ Heidegger, Ser e Tempo, 2012, p.539

${ }^{127}$ Heidegger, Ser e Tempo, 2012, p.573

${ }^{128}$ Heidegger, Ser e Tempo, 2012, p.557 (Grifado nosso)

${ }^{129}$ Heidegger, Ser e Tempo, 2012, p.547

${ }^{130}$ Heidegger, Ser e Tempo, 2012, p.641-643
} 
apropriarmos dela, devemos compreender também sua propriedade. Visto que o impróprio é caracterizado como não-todo ${ }^{131}$. A totalidade é mostrada pela possibilidade de chegar ao seu todo, de completar-se. Mas esta completude jamais pode se dar de maneira total, pois ao Dasein pertence sempre algo que "falta", como um ainda-não, que lhe constitui e lhe possibilita ser o projeto-lançado (aberto) existencial que ele é. Como vimos, o Dasein a cada vez tem de ser. Segundo Heidegger, os demais entes podem se completar, por exemplo, o fruto maduro se completaria. Tal afirmação vai ao encontro de sua descrição de que todo ente não-conforme o Dasein não possui o caráter de existente, mas é visto em sua maioria como presença adiante da mão. O chegar-ao-final do Dasein como a possibilidade de sua completude, nunca acontece. A morte, que seria este chegar-ao-final do Dasein, é desde sempre uma possibilidade que o Dasein assume logo que é. Possibilidade essa, intransferível e singular, pois ninguém pode experimentar a morte por ninguém, sendo irremetente, ela coloca o próprio ser do Dasein em jogo ${ }^{132}$. Na medida em que ela se mostra como a possibilidade extrema de não ser mais o aí (aberto) - de não ser mais o Dasein - e, por isso, se desvendaria como a possibilidade mais própria, irremetente e insuperável ${ }^{133}$, em que o Dasein já está sempre lançado.

Vimos, no entanto, que a possibilidade própria se mostra velada na cotidianidade impessoal na qual o Dasein se encontra na maior parte das vezes. Como esta possibilidade própria pode então se desvelar, uma vez que toda possibilidade do Dasein acaba sendo absorvida na decadência imprópria cotidiana? A propriedade, segundo Heidegger, acena para a sustentação da possibilidade como possibilidade, sem atenuação ou encobrimento, possibilitando o ser-para-a-morte próprio. "Projetar-se sobre o poder-ser mais-próprio, significa: poder se compreender a si mesmo, no ser do ente assim desvendado: existir." ${ }^{134} \mathrm{~A}$ possibilidade de compreender a si mesmo se dá no isolamento de si mesmo que a morte apresenta. A existência própria compreende, então, suas possibilidades como finitas, de modo que somente a partir da antecipação de sua possibilidade mais extrema (a morte), pode o Dasein existir como poder-ser todo. Tal

\footnotetext{
${ }^{131}$ Heidegger, Ser e Tempo, 2012, p.645

${ }^{132}$ Heidegger, Ser e Tempo, 2012, p.663

${ }^{133}$ Heidegger também nos descreve o caráter certo e indeterminado da morte, certa de que um dia vai acontecer, mas tendo o seu quando indeterminado, uma vez que não se sabe quando ela chegará.

${ }^{134}$ Heidegger, Ser e Tempo, 2012, p.723
} 
antecipação é possibilitada na angústia, pois só ante o nada da possível impossibilidade de sua existência (a morte) que tal possibilidade extrema pode se abrir como liberdade para a morte. Libertando o Dasein das possibilidades cotidianas impróprias que nos advêm.

Por uma necessidade de comprovação desta propriedade, Heidegger recorre a um testemunho. Afinal, quem poderia testemunhar tal propriedade? A atestação deve vir do ser do Dasein, visto que o que se atesta é o Dasein próprio. O salto da modificação existencial do impessoalmente-si-mesmo para o ser-si-mesmo próprio se dá a partir de uma busca-de-si, um ir em busca de uma escolha, escolher essa escolha, decidir-se por um poder-ser a partir de um propriamente simesmo, que Heidegger vai chamar de ser-resoluto ${ }^{135}$. Perdido no impessoal, o Dasein deve se achar como si mesmo próprio. Para que isso ocorra uma modificação na apreensão do si mesmo deve se dar. Não mais apreendido a partir da cotidianidade decadente, o Dasein deve se apreender originariamente a partir da compreensão da intimação de um apelo, o querer-ter-consciência. Ouvindo os outros - o falatório curioso e ambíguo - o Dasein está perdido no impessoal, outro modo de ouvir deve se dar para que esta escuta decadente seja interrompida. "A possibilidade de tal ruptura reside no ser-intimado sem mediação. O apelo [modus de discurso próprio] rompe o ouvir impessoal, no qual o Dasein não se ouve [...] Aquilo que, apelando dessa forma, dá a compreender é a consciência." 136 O que é discorrido e intimado no apelo? O apelo atinge o impessoalmente si mesmo e o intima ao próprio si-mesmo, ao ser-no-mundo como tal. O discorrido não pode ser nada do mundo cotidiano, deste modo, a consciência que apela discorre silenciosamente, convocando-o para suas possibilidades mais próprias. O Dasein é o próprio apelante e o intimado, não de modo arbitrário, por sua própria vontade, e isto Heidegger se esforça para deixar claro; mas este discurso silencioso vem de mim e além de $\operatorname{mim}^{137}$ : de um mimpróprio, como um apelo que surge do Dasein em seu estranhamento angustiante (disposição) e atravessa despertando o Dasein cotidiano em seu impessoalmentesi-mesmo ${ }^{138}$.

\footnotetext{
${ }^{135}$ Heidegger, Ser e Tempo, 2012, p.741

${ }^{136}$ Heidegger, Ser e Tempo, 2012, p.745 (Grifado nosso)

${ }^{137}$ Heidegger, Ser e Tempo, 2012, p.757

${ }^{138}$ Heidegger, Ser e Tempo, 2012, p.763
} 
A voz da consciência fala de algum modo de dívida $(\text { Shuld })^{139}$, como compreendermos a ideia de dívida a partir da interpretação do Dasein? ${ }^{140 ~ " E m ~}$ toda visão do falso se descobre ao mesmo tempo uma indicação da 'ideia' originária do fenômeno." ${ }^{141}$ Como vimos, este movimento característico de Heidegger, de um derivado em relação a um originário, vai nos conduzir a noção de dívida mais originária. O ser "endividado" cotidiano é muitas vezes compreendido como aquele que tem de pagar uma conta, tem de se haver com, de modo que ele possui o significado de "ser responsável de". Para alcançarmos a originariedade do fenômeno devemos excluir os fenômenos vulgares - cotidianos - de dívida, que dariam a ideia de defeito ou falta de algo característico de um ente presente adiante da mão, tal exclusão é também característica do pensamento heideggeriano. Uma vez que se exclui o vulgar para ir ao encontro do originário. Haveria na ideia de dívida o caráter de um não e de uma responsabilidade que Heidegger vai denominar ser em dívida, isto é, como "ser-fundamento de um ser determinado por um não - isto é, ser-fundamento de uma nulidade."142 Este - não - excluiria a referência a uma possível presença adiante da mão, pertencendo ao sentido existencial do projeto-lançado, tal nulidade - caráter-de-não - revela o lançado como si mesmo e o projeto negativo nos quais o Dasein sempre se mantem existenciariamente. Tal nulidade pertence ao ser-livre do Dasein, livre para as possibilidades que são suas. O Dasein é nulidade de ponta a ponta, seu ser - como cuidado - é marcado por esta negatividade ontológica. Um não que está sempre se lançando e nunca se completa ou deixa de se lançar. O que o apelo dá a compreender é no fundo este ser em dívida, esta nulidade fundamental do Dasein. Só assim, o si mesmo escolhe "o ter consciência como ser-livre para o ser em

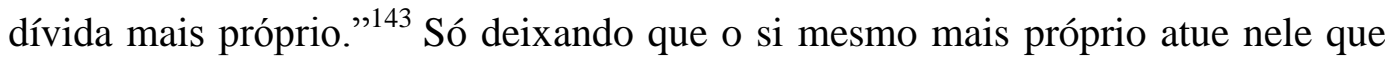
ele pode vir a ser responsável. A responsabilidade de si mesmo está relacionada à possibilidade do Dasein assumir o poder-ser-no-mundo que ele mesmo é, de assumir seu caráter existencial que se encontra velado pelos modos de ser impessoais. Responsável, o Dasein se entrega à responsabilidade desse ser que é o

\footnotetext{
${ }^{139}$ Esta pesquisa se utiliza da tradução de Marcos Casanova do termo Schuld por dívida e não culpa traduzido por Fausto Castilho.

${ }^{140}$ Heidegger, Ser e Tempo, 2012, p.771

${ }^{141}$ Heidegger, Ser e Tempo, 2012, p.771

${ }^{142}$ Heidegger, Ser e Tempo, 2012, p.777

${ }^{143}$ Heidegger, Ser e Tempo, 2012, p.789
} 
dele ${ }^{144}$. Nesse sentido, Haar nos descreve: “estar-em-dívida é ser responsável de um não, de uma negatividade [...] é ser fundamento de um não, é sobretudo ser um fundamento afectado de não." ${ }^{145} \mathrm{E}$ Duarte também nos esclarece acerca da responsabilidade:

Para Heidegger, a compreensão própria da dívida ${ }^{146}$ ontológica que cada um é não o dispensa da responsabilidade de ser e de agir, mas é a condição primeira para que ele seja responsável e "aja em si", arrancando-se da perdição [...] da publicidade impessoal. Para Heidegger, somente o Dasein que se reconhece em seu "ser-paraa-morte" pode resolver-se a agir propriamente, ou seja, pode apropriar-se do seu agir, assumindo responsabilidades para consigo e para com os outros, sem dispor de critérios visando a garantir de uma vez por todas o caráter moral de sua conduta. ${ }^{147}$

Como modo de abertura próprio a compreensão (própria) se caracteriza como este querer-ter-consciência - que se projeta no ser em dívida mais próprio, que no estranhamento de seu isolamento fica-pronto para a angústia (disposição própria), tendo como discurso originário o ser-silencioso (calado), característico do apelo. Estes três momentos vão caracterizar a abertura do Dasein próprio que Heidegger denominou ser-resoluto (Entschlossenheit). Só neste ser resoluto conquistamos "a mais originária, porque própria, verdade do Dasein." ${ }^{148}$ Em relação a que o Dasein resoluto se resolveria? A resposta só poderia ser dada pela resolução ela mesma, afirma Heidegger.

Nosso intuito não será acompanhar o pensamento de Heidegger acerca da essência da verdade, mas pensá-lo sempre em sua relação fundamental com o que ele compreende por humano. Em Ser e Tempo, a verdade estará intimamente ligada ao modo de ser do Dasein como ser-descobridor, ser-verdadeiro ${ }^{149}$. Em seus modos de ser o Dasein descobre o ente que é o descoberto. "O ser-descoberto do ente do-interior-do-mundo se funda na abertura do mundo. Mas a abertura é o modo-de-ser-fundamental do Dasein," $" 150$ como ser-no-mundo. Só com a abertura do Dasein atinge-se o fenômeno mais originário da verdade ${ }^{151}$. "Só se dá verdade

\footnotetext{
${ }^{144}$ Heidegger, Ser e Tempo, 2012, p.527, Veja também Duarte, Vidas em Risco: crítica do presente em Heidegger, Arendt e Foucault. 2010, p.423

${ }^{145}$ Haar, Heidegger e a essência do homem, 1990, p.50

${ }^{146}$ Haar utiliza o termo débito para traduzir Schuld. Mantivemos o termo dívida com o intuito de manter a coerência do texto.

${ }^{147}$ Duarte, Vidas em Risco: crítica do presente em Heidegger, Arendt e Foucault. 2010, p.426

${ }^{148}$ Heidegger, Ser e Tempo, 2012, p.813

${ }^{149}$ Heidegger, Ser e Tempo, 2012, p.609

${ }^{150}$ Heidegger, Ser e Tempo, 2012, p.611

${ }^{151}$ Heidegger, Ser e Tempo, 2012, p.611
} 
na medida em que o Dasein é." ${ }^{152}$ Como ao Dasein pertence a decadência, o ente descoberto pelo ser-descobridor decai, e se dissimula, sendo na não-verdade ${ }^{153}$. O fechamento e o encobrimento fazem parte da constituição positiva do Dasein. Sendo assim, o Dasein é na verdade e na não verdade, "só na medida em que é aberto [descobridor - verdadeiro], o Dasein é também fechado [não verdadeiro]; e na medida em que o ente do interior-do-mundo é cada vez descoberto [verdade] com o Dasein, esse ente, podendo vir-ao-encontro no interior-do-mundo, é encoberto (oculto) ou dissimulado [não-verdade]." 154 Ser e Verdade "são" de igual originariedade na medida em que o Dasein é ${ }^{155}$. Ambos pertencem à constituição essencial do Dasein - a abertura ao ser.

Ainda não atestado e acessível suficientemente em seu ser-todo-próprio, o autor alemão nos pergunta sobre a possibilidade de unir os fenômenos da totalidade do Dasein no ser-para-a-morte próprio e na atestação existencial do serresoluto próprio. Nas palavras do próprio autor, ele nos pergunta: e "se só no antecipar-se para a morte se compreendesse, de modo próprio, isto é, se alcançasse existencialmente toda a 'provisoriedade' factual do resolver?" ${ }^{156} \mathrm{O}$ serresoluto seria antecipador, pois ele "abriga em si o ser-para-a-morte próprio como modalidade existencial possível de sua própria propriedade." ${ }^{157}$ A morte é a impossibilidade da existência, ela é a própria nulidade do Dasein. O Dasein é fundamento lançado - nulo - de sua morte. Esta nulidade do estar em dívida é descoberta no ser-para-a-morte próprio, no fundamento do ser um todo do Dasein. O ser-resoluto antecipador compreende-se própria e totalmente, isto é, originariamente. "Com o fenômeno do ser resoluto fomos conduzidos ante a verdade originária da existência." ${ }^{158}$ Ele é o próprio descobrir e o ficardescoberto. Ele dá a si mesmo a situação hermenêutica factual de modo que ela (a situação) não se deixa calcular como uma presença adiante da mão, mas fica aberta indeterminada livre para resolver-se, aberta à determinabilidade ${ }^{159}$. Só assim ele se conquista como ser responsável pelo poder-ser-no-mundo que ele mesmo é. O ser-resoluto se mantem livre para sua possível e cada vez

\footnotetext{
${ }^{152}$ Heidegger, Ser e Tempo, 2012, p.625

${ }^{153}$ Heidegger, Ser e Tempo, 2012, p.615

${ }^{154}$ Heidegger, Ser e Tempo, 2012, p.615

${ }^{155}$ Heidegger, Ser e Tempo, 2012, p.635

${ }^{156}$ Heidegger, Ser e Tempo, 2012, p.827

${ }^{157}$ Heidegger, Ser e Tempo, 2012, p.835

${ }^{158}$ Heidegger, Ser e Tempo, 2012, p.839

${ }^{159}$ Heidegger, Ser e Tempo, 2012, p.839
} 
factualmente necessária retomada, repetindo o seu si-mesmo, tendendo a manterse constantemente livre para seu poder-ser todo próprio. Ele "sabe da indeterminação que predomina de um extremo a outro no ente que existe."160 A abertura do Dasein mantém-se com igual possibilidade a perda no ser-irresoluto impessoal impróprio. Ambas as possibilidades se mostram certas para o Dasein.

A propriedade e a impropriedade estão sempre em jogo no Dasein, assim como os elementos característicos de cada modo de abertura. Neste sentido, um Dasein não transparente está imerso nos modos de ser cotidianos, tragado pela curiosidade, pela ambiguidade e pelo falatório. Não se questiona e não está livre tampouco responsável em relação ao seu si-mesmo. Mas encontra-se perdido no impessoal. Sem dúvida os elementos de propriedade deste ente se encontram presentes, mas no modo da dissimulação. Por outro lado, ao se revelarem, este modo próprio do ser-si-mesmo dão ao Dasein a transparência e a liberdade do serresoluto singular antecipador, apreendendo-se como fundamento nulo, em dívida, o que acena para a responsabilidade de si mesmo e apreensão de sua totalidade e unidade como cuidado. Neste modo próprio ele também carrega consigo os elementos da impropriedade, mas como uma modificação existencial. Não mais totalmente dissimulada e inquestionada.

Fica mais clara com a descrição da analítica existencial, a unidade de ser do Dasein, deste ente que nós mesmo somos, em que medida a existência está assentada numa abertura ao ser. Justamente por ser aberto ao ser, o Dasein humano, nesta obra, é um ponto arquimediano para a transformação do mundo. A quebra das determinações de mundo históricas e tradicionais que sustentam os comportamentos do Dasein cotidiano acabam abrindo espaço para outro modo do mundo se determinar. Este papel nas obras de Heidegger acaba se deslocando do Dasein para o próprio mundo. Como foi esclarecido, esta pesquisa não vai descrever como Heidegger desenvolve estas transformações, nem vamos apontar os passos deste autor acerca de um chamado primeiro Heidegger para um segundo. O objetivo aqui é apontar em que medida o que Heidegger compreende por Dasein acena para uma quebra na compreensão do homem pela tradição e como o autor passa a descrever o próprio humano em questão. A partir da analítica, pudemos ver que seu caráter existencial assentado sobre sua abertura ao

$\overline{{ }^{160} \text { Heidegger, Ser e Tempo, 2012, p.841 }}$ 
ser é fundamental para esta quebra e para nos questionarmos acerca do modo como nos relacionamos e compreendemos o homem. Neste sentido, a compreensão deste todo existencial do humano chamado de cuidado foi necessária para vermos que cada estrutura deste ente está assentada sobre esta abertura ao ser característica do Dasein, trazendo certa dinamicidade e flexibilidade ao que antes era compreendido pela tradição a partir de características quididativas, substanciais, coisificadas, determinadas atemporalmente. A unidade de ser (cuidado) deste ente está assentada, por sua vez, sobre a temporalidade. E por isso, Heidegger nos descreve nos Seminários de Zollikon que o si-mesmo é temporal e não pode de forma alguma ser tomado como algo presente para além do tempo. Logo o ser do Dasein também se temporaliza.

É importante compreendermos neste ponto de nossa pesquisa os textos que Heidegger descreve diretamente o que e como compreende o humano e alguns dos aspectos que estão em jogo em cada um deles, acenando, de alguma forma, para certo deslocamento do papel do Dasein humano na obra heideggeriana. Ele não deixa de ser o ente privilegiado, mas o peso da transformação de mundo se desloca, não mais como ente resoluto antecipador que abre espaço para a transformação do ser, ele passa a ser pastor e guardião da abertura do ser.

\section{2}

\section{Carta sobre o humanismo: Dasein, próprio e linguagem.}

Em carta Sobre o humanismo (1947/1973), Heidegger fala mais diretamente o que compreende por humano e por humanismo, e ao mesmo tempo coloca seu pensamento diante desta compreensão. Ele vai trabalhar a partir da relação Ser Linguagem (como "depósito" 161 do pensar) - Homem (Dasein humano) nos mostrando o que seria mais digno de ser pensado: a questão acerca do ser. Vamos aos poucos, compreender a importância desta tríplice relação. O pensar, nesta obra, descreve aquilo que consuma a relação ser e homem, pois nele, no pensar, o ser tem acesso à linguagem. Ele oferece a relação ser-homem ao ser "como aquilo que a ele próprio foi confiado pelo ser." ${ }^{162}$ Sobre a relação ser linguagem - pensar, Heidegger nos esclarece que "a única tarefa do pensar é

\footnotetext{
${ }^{161}$ Heidegger, Sobre o humanismo, 1973 , p.370

162 Heidegger, Sobre o humanismo 1973, p.347
} 
trazer à linguagem, sempre novamente, este advento do ser." ${ }^{163}$ Em outra passagem, o autor nos diz que "o pensar traz à linguagem, em seu dizer, apenas a palavra pronunciada do ser." ${ }^{164}$ Nesta relação, a "linguagem é a casa do ser,"165 “casa da verdade do ser"166. Aos poucos, vai ficando mais claro esta relação pensar - linguagem - ser, na medida em que linguagem é a casa da verdade do ser e o pensar traria para a linguagem o advento do ser, depositando na linguagem este advento. Onde o homem entraria nesta relação? O homem habita na linguagem, na medida em que a linguagem é a casa do ser. Este morar é a essência do ser-no-mundo ${ }^{167}$. O autor nos recorda da relação do Ser-em com o morar em Ser e Tempo ${ }^{168}$. Dessa forma, vemos que o pensar traz para a linguagem, onde habita o homem, a pronunciação do ser, o dizer do ser, o advento do ser. O pensar diz e no seu dizer pertence uma saga/tradição/dizer (Sage), mais adequada, mais livre ao que constitui a essência da questão em relação às ciências, uma vez que ele (o pensar) deixa que o ser seja ${ }^{169}$. A metafísica e as ciências pensam o ser como ente esquecendo-se do ser e assim, acabam por esquecer e, talvez, impedir que o homem atinja sua originária relação com o ser. As ciências humanas, logo, o humanismo não questionaria a relação do ser com o ser humano ${ }^{170}$. E acabariam pressupondo a essência do humano, ou seja, determinando o homem antes mesmo dele ser. Não seria, de certo modo, esta prédeterminação que está em jogo nas categorias dos manuais do CID -10 (Classificação Estatística Internacional de Doenças e Problemas Relacionados com a Saúde) ou do DSM-V (Manual Diagnóstico e Estatístico de Transtornos Mentais)? Já o pensamento do ser, dócil a voz do ser, pensa o que lhe foi destinado ${ }^{171}$. Ele pensa o ser e pertence ao ser, pois é requisitado por ele. É neste sentido que Heidegger vai dizer que hoje não se pensa. É justamente à este pensamento do ser que ele está querendo nos chamar a atenção. Um pensamento que veremos ser destinal e, por isso, historial. "O ser é como o destino do pensar. O destino, porém, é em si historial. Sua história já

\footnotetext{
${ }^{163}$ Heidegger, Sobre o humanismo 1973, p.372

${ }^{164}$ Heidegger, Sobre o humanismo 1973, p.371

${ }^{165}$ Heidegger, Sobre o humanismo 1973, p.347.

${ }^{166}$ Heidegger, Sobre o humanismo 1973, p.350

${ }^{167}$ Heidegger, Sobre o humanismo, 1973, p.370

${ }^{168}$ Heidegger, Sobre o humanismo, 1973, p.370

${ }^{169}$ Heidegger, Sobre o humanismo, 1973, p.370

${ }^{170}$ Heidegger, Sobre o humanismo, 1973, p.351

${ }^{171}$ Heidegger, Que é metafísica? [introdução] 1949/1973, p.256
} 
chegou à linguagem, no dizer dos pensadores." ${ }^{172}$ Em outra passagem, ele também relaciona os pensadores ao destino do ser, como os que participam da verdadeira questão: a questão do ser. "A disputa entre pensadores é a "disputa amorosa" da questão mesma. Ela auxilia-os alternadamente a penetrar na simples participação no mesmo, a partir do qual eles encontram a docilidade no destino do ser."173 Talvez, Heidegger esteja sugerindo que estes pensadores para pensarem o ser, teriam ouvido a voz do ser, teriam, talvez, experienciado a angústia (abertura privilegiada ao ser) e, assim, experienciado o próprio ser. Talvez, seja mesmo isso que ele esteja sugerindo nas passagens a seguir: "o pensamento suscitado pelo ente enquanto tal, que por isso representa e esclarece o ente [pensamento da metafísica], será substituído [quando o pensamento se tornar mais pensamento] por um pensamento instaurado pelo próprio ser e por isso dócil à voz do ser."

"Somente o homem, em meio a todos os entes experimenta [pela disposição da angústia], chamado pela voz do ser, a maravilha de todas as maravilhas: que o ente é. [...] A clara coragem para a angústia essencial garante a misteriosa possibilidade da experiência do ser. [...] Ela [a coragem da angústia] pensa apenas aquilo que apareceu ao pensamento ocidental, desde o começo, como aquilo que deve ser pensado e permaneceu, entretanto esquecido: o ser. Mas o ser não é produto do pensamento. Pelo contrário, o pensamento essencial é um acontecimento provocado pelo ser." ${ }^{175}$

A linguagem como casa e habitação do ser é onde mora o homem e os guardas desta casa são os pensadores e os poetas, pois são eles que consumariam a manifestação do ser. Podemos dizer de certa forma, que são eles que pensam, que participam da questão mesma: a questão do ser. Pois levam a manifestação do ser para a linguagem e nela a conservam ${ }^{176}$. O pensar seria o engajamento para o ser e pelo ser em favor da verdade do ser ${ }^{177}$. Ele pertence ao ser e escuta o ser, sendo requisitado por ele. O ser ao imperar sobre o pensar, ao encarregar-se sobre o destino do pensar, impera, assim, sobre a essência do homem, ou seja, sobre sua relação com o $\operatorname{ser}^{178}$. O que Heidegger começa a acenar neste ponto do texto é para certo esvaziamento da linguagem, já indicado em Ser e tempo pelo próprio autor $^{179}$, ameaçando assim à essência do homem, jogando-o ao domínio da

\footnotetext{
${ }^{172}$ Heidegger, Sobre o humanismo 1973, p.372

${ }^{173}$ Heidegger, Sobre o humanismo, 1973, p.358

${ }^{174}$ Heidegger, Que é metafísica? [introdução], 1949/1973, p.256

${ }^{175}$ Heidegger, Que é metafísica? [posfácio], 1943/1973, p.247 (Grifado nosso)

${ }^{176}$ Heidegger, Sobre o humanismo 1973, p.347

${ }^{177}$ Heidegger, Sobre o humanismo 1973, p.347

${ }^{178}$ Heidegger, Sobre o humanismo 1973, p.349

${ }^{179}$ Heidegger, Sobre o humanismo, 1973, p.349
} 
subjetividade, na incondicional objetivação de tudo e com isso, na inverdade do ser.

Vamos abrir um espaço para tentar compreender o que Heidegger entende por verdade como verdade do ser. Após a dita virada heideggeriana, haverá um deslocamento do papel do Dasein, não mais como o ente resoluto antecipador da morte que, ao se conquistar abriria espaço para uma possível transformação de mundo, mas o mundo mesmo passa a se transformar a partir do próprio acontecimento do ser. Nesse sentido, o Dasein continua com um papel privilegiado, mas não carrega mais o peso desta abertura às transformações possíveis, sendo agora o pastor e guardião deste espaço de abertura do ser. Dessa forma, a verdade também acaba sendo deslocada, não mais dependente da abertura do Dasein, ela agora passa a estar relacionada à história do ser, a essência da verdade como a verdade da essência, das essencializações históricas, dos desdobramentos da interpretação do ente na totalidade. Vamos descrever brevemente como Heidegger nos mostra esta relação.

A verdade do ser, em A essência da verdade (1943/1973) acena para a manifestação do ser no desvelamento (alétheia). Esta essência desveladora seria a própria verdade do ser $^{180}$. Desvelamento este que permanece velado para as ciências e para a metafísica. Ele superaria a metafísica, mas não a rejeitaria ${ }^{181}$. Buscando pensar o chão, os fundamentos a partir dos quais se desenvolveria a própria filosofia e a metafísica. A verdade para a metafísica apareceria, dessa forma, velada, uma vez que esta está ligada apenas ao ente e desconsidera por completo o ser. Ela apareceria derivada na forma do conhecimento e da enunciação (veritas) ${ }^{182}$. Veritas seria a definição tradicional da essência da verdade como adequação e conhecimento, como conformidade e concordância ${ }^{183}$. Para que algo concorde, um enunciado com a coisa, por exemplo, já seria necessário um comportamento tal em que algo se manifeste e assim que algo se conforme com o enunciado. Nesse sentido, Heidegger conclui, "então aquilo que torna possível a conformidade possui um direito mais original de ser considerado

\footnotetext{
${ }^{180}$ Heidegger, Que é metafísica? [introdução], 1949/1973, p.253

${ }^{181}$ Heidegger, Que é metafísica? [introdução], 1949/1973, p.254

${ }^{182}$ Heidegger, Que é metafísica? [introdução], 1949/1973, p.255 Concepção tradicional da essência da verdade já descrita em Ser e Tempo, 2012, p.595

${ }^{183}$ Heidegger, Da essência da verdade, 1973, p.331-332
} 
como a essência da verdade." ${ }^{184}$ É a partir daí que Heidegger abre um espaço para pensar a verdade a partir do desvelamento (Alétheia), a partir do desvelamento do ser. Desvelamento que marcaria a possibilidade de toda medida, de uma concordância, de um cálculo, marcaria também o modo como o ente se desvela ao homem. O modo como o ente se desvela revelaria ainda a história da verdade do ser. Nas palavras do autor:

O desvelamento inicial do ente em sua totalidade [da questão do ser do ente ${ }^{185}$ ], a interrogação pelo ente enquanto tal [primeiro pensador que se pergunta o que é o ente, primeiro que é tocado pelo desvelamento do ente, quando o ente é pela primeira vez experimentado em seu desvelamento, em sua totalidade, ele se revela como physis] e o começo da história ocidental [somente onde o ente é mantido em seu desvelamento, quando tal sustentação é compreendida à luz da pergunta pelo ente enquanto tal, começa a história] são uma e mesma coisa; eles se efetuam ao mesmo "tempo", mas este tempo, em si mesmo não mensurável, abre a possibilidade de toda medida. ${ }^{186}$

Este desvelamento (do ser do ente, da verdade do ser e da história ocidental) é, contudo, marcado por uma dissimulação, um velamento no qual cotidianamente estamos, ele é mais antigo ${ }^{187}$ que o desvelamento. Estamos esquecidos do ente em sua totalidade, imersos em cálculos e projetos sem questionar a essência do que dá estas medidas, sem questionar a verdade do ser. "O desvelamento do ente enquanto tal é, ao mesmo tempo e em si mesmo, a dissimulação do ente em sua totalidade." ${ }^{188}$ Nesse sentido, Heidegger conclui, "Verdade significa o velar iluminador enquanto traço essencial do ser (Seyn) [diferença entre ser e ente pensa a verdade da essência, das presentificações do ser ${ }^{189}$ ]. [...] o velar iluminador é, quer dizer, faz com que se desdobre (Wesen) [essencialize] a concordância entre conhecimento e ente." ${ }^{190}$ Em outra passagem ele interliga verdade do ser, em seu desvelamento e velamento e história do ser, "o evento da história se desdobra em ser como o destino da verdade do ser. [...] Ao destino

\footnotetext{
${ }^{184}$ Heidegger, Da essência da verdade, 1973, p.334

${ }^{185}$ Heidegger, Da essência da verdade, 1973, p.341

${ }^{186}$ Heidegger, Da essência da verdade, 1973, p.336 (Grifado nosso)

${ }^{187}$ Heidegger, Da essência da verdade, 1973, p.337

${ }^{188}$ Heidegger, Da essência da verdade, 1973, p.341

189 “O pensamento metafísico só pensa o ente e não o ser, precisamente por que o ser significa para ele somente a presença daquilo que é presente, a entidade, e não o acontecimento [l'événement] da presença advindo em benefício da aparição do ente." Dastur, Heidegger, Derrida et la question de la différence, In. Derrida, la tradition de la philosophie, 2008, p.101

${ }^{190}$ Heidegger, Da essência da verdade, 1973, p.343
} 
chega o ser, na medida em que ele, o ser, se dá. Mas isto significa, quando pensando com docilidade ao destino: ele dá-se e recusa-se simultaneamente."191

Nesse sentido, história do ser e verdade do ser como desdobramento da verdade da essência se interligam no que Heidegger chamou de virada. "A resposta à questão da essência da verdade é a dicção de uma viravolta ${ }^{192}$ no seio da história do ser (Seyn). Porque ao ser pertence o velar iluminador, aparece ele originariamente à luz da retração que dissimula. O nome desta clareira é: alétheia." ${ }^{193}$ Em Ser e Tempo trataria-se de algo precursor e, talvez, ainda desajeitado, mas parte de um caminho [da interpretação do ser] que ainda não foi desencadeado, mas preparado pela própria investigação de Ser e Tempo. Nesse sentido Heidegger faz apelo para que continuemos como viajadores neste caminho para a vizinhança do ser ${ }^{194}$. Assim o autor nos descreve:

O que fica para dizer poderia eventualmente transformar-se num estímulo para levar a essência do homem a atentar, com seu pensar, para a dimensão da verdade do ser que perpassa com seu domínio. Isso só poderia acontecer em favor da dignidade do ser $[\ldots]$ e não por causa do homem. ${ }^{195}$

A partir destes parágrafos iniciais, podemos perceber que o autor alemão vai apontar alguns pontos importantes em Sobre o humanismo que vamos destacar para que sejam pontos a serem lembrados ao longo desta parte do texto.

- A tríplice relação: pensar (linguagem como este depósito de acolhimento do pensar: "O pensar [...] deposita seu dizer do ser na linguagem." ${ }^{196}$ ) - homem (humano) - ser;

- Ao domínio da subjetividade e da consequente objetivação de tudo como um não pensar. Uma vez que não se consuma o ser com a essência do homem e com isso a linguagem cai sob a ditadura da opinião pública. Então, hoje não se pensa e a linguagem está decaída. A partir dessa compreensão, como o homem (humano) se encontraria hoje?;

\footnotetext{
${ }^{191}$ Heidegger, Sobre o humanismo, 1973, p.358

${ }^{192}$ Em carta Sobre o humanismo, o autor retoma o texto a essência da verdade e nos diz "a conferência Sobre a Essência da Verdade, pensada e levada a público em 1930, mas apenas impressa em 1943, oferece certa perspectiva sobre o pensamento da viravolta de Ser e Tempo para Tempo e Ser [Terceira Seção da primeira parte de Ser e Tempo que foi retida]. Esta viravolta não é uma mudança do ponto de vista de Ser e Tempo; mas, nessa viravolta, o pensar ousado alcança o lugar do âmbito a partir do qual Ser e Tempo foi compreendido e, na verdade, compreendido a partir da experiência fundamental do esquecimento do ser." (Heidegger, Sobre o humanismo, 1973, p.354)

${ }^{193}$ Heidegger, Da essência da verdade, 1973, p.343

${ }^{194}$ Heidegger, Sobre o humanismo, 1973, p.363

${ }^{195}$ Heidegger, Sobre o humanismo, 1973, p.355

${ }^{196}$ Heidegger, Sobre o humanismo, 1973, p.371
} 
- A perda deste genuíno pensar e a queda (esvaziamento) da linguagem provém de uma ameaça à própria essência do homem. O homem não compreende sua essência e assim, tampouco, o pensar e a linguagem;

- Ser e tempo já continha uma indicação para a dimensão essencial da linguagem (parágrafo 34) e para a essência do homem;

- Existe uma relação ainda não esclarecida entre destino do pensar e História do ser.

A linguagem esvaziada (decaída) no pensamento metafísico recusa-se a pensar-se como casa do ser, casa da verdade do ser e abandona-se como instrumento de dominação do ente. Como já apontado, haveria um domínio da subjetividade que objetiva tudo, controlando e calculando a partir de leis causais ${ }^{197}$. A maneira de se "salvar", podemos dizer, seria encontrar o caminho para a proximidade do ser, escutando novamente o apelo do ser, pois só assim ele [o homem] será gratificado para residir na casa e na verdade do ser. Só assim conseguiremos pensar e sermos [nós] guardiões dessa casa. Heidegger, neste ponto do texto retoma o cuidado (unidade de ser do Dasein humano já trabalhado em Ser e tempo) como uma recondução do homem à sua essência. Para que o homem se torne humano, deve ele meditar e cuidar "para que o homem seja humano e não des-humano, inumano, ou seja, fora de sua essência." ${ }^{198}$ Hoje viveríamos uma desumanização, na medida em que o homem se encontra fora de sua essência, descuidado, ele, hoje, não pensa o ser, não escuta o apelo do ser e não se encontra no caminho para a proximidade do ser. A humanidade do homem repousa justamente em sua essência, que como vimos é a própria relação com o ser, sua proximidade com o ser, consumada no pensar. Esta proximidade diz respeito ao seu caráter mais próprio, a essência mesma do homem: a relação com o ser, a abertura ao ser.

Neste ponto da carta, Heidegger começa a se aproximar mais diretamente da pergunta realizada por Jean Beaufret: Como tornar a dar sentido à palavra "humanismo"? Para o autor alemão "todas elas [as diferentes espécies de humanismos] coincidem nisto que a humanitas do homo humanus é determinada a partir do ponto de vista de uma interpretação fixa da natureza, da história, do mundo, do fundamento do mundo, e isto significa, desde o ponto de vista do ente

\footnotetext{
${ }^{197}$ Heidegger, Sobre o humanismo 1973, p.350

${ }^{198}$ Heidegger, Sobre o humanismo 1973, p.350 (Grifado nosso)
} 
em sua totalidade." ${ }^{\prime 199}$ A determinação da essência do homem já pressuporia, nos diversos humanismos, a interpretação do ente, sendo assim metafísica. Pressuporia como óbvia, desde os primeiros humanismos (romano), a "essência" universal do homem, o homem como animal rationale ${ }^{200}$ que é animal metaphysicum $^{201}$. O que se perde aí é a própria relação do ser humano com o ser, na medida em que o ser é determinado aprioristicamente na interpretação do ente. Ou seja, toma-se o ser como ente, questão já apontada em Ser e Tempo, e esquecese da diferença entre ambos ${ }^{202}$. Heidegger assim, critica a interpretação a priori do homem como animal racional em todos os humanismos, não para negá-lo ou apontá-lo como falso, mas para acenar para seus limites metafísicos e questionálos. Limites estes já acenados em Ser e tempo ${ }^{203}$. Compreendendo a essência do homem poderíamos, talvez começar a meditar sobre o pensamento do ser e a possibilidade de uma linguagem como casa do ser e depósito de seu pensar.

Como não se questiona acerca do ser e da diferença entre ser e ente, tampouco se questiona acerca do pertencimento entre a essência do homem e a verdade do ser. A metafísica e as ciências humanas estão fechadas para o fato de que o homem desdobra seu ser em sua essência, enquanto recebe o apelo do ser ${ }^{204}$. "A história do ser sustenta e determina cada condition e situation humaine."205 Vai ficando mais claro em que medida o ser destinado marca historialmente a essência dos homens. Uma vez que o homem é o ente que está posto (exposto) na clareira do ser (na verdade do ser) - (na abertura do ser). Para este modo de ser Heidegger denominou a ecsistência do homem ${ }^{206}$. Este estar postado para o ser, estar em relação com o ser só é próprio do homem ${ }^{207}$. Só o homem está “iniciado no destino da ec-sistência." ${ }^{208}$ Para explicar o que Heidegger compreende por ecsistência, o autor retoma sua frase em Ser e Tempo, em que diz que "a essência do Dasein reside em sua existência." A frase diz: "o homem desdobra-se assim em

\footnotetext{
${ }^{199}$ Heidegger, Sobre o humanismo 1973, p.351

${ }^{200}$ Heidegger, Sobre o humanismo, 1973, p.351

${ }^{201}$ Heidegger, Que é metafísica? [introdução], 1949/1973, p.370

${ }^{202}$ Heidegger, Sobre o humanismo 1973, p.352

${ }^{203}$ Heidegger, Sobre o humanismo 1973, p.351

204 "Este chamado [apelo] vem como o lance do qual se origina a condição de ser-jogado [lançado] do Dasein." Heidegger, Sobre o humanismo, 1973, p.361-362

${ }^{205}$ Heidegger, Sobre o humanismo 1973, p.347

${ }^{206}$ Heidegger, Sobre o humanismo 1973, p.352

207 "Somente o homem, em meio a todos os entes experimenta [pela disposição da angústia], chamado pela voz do ser, a maravilha de todas as maravilhas: que o ente é." (Heidegger, Que é metafísica? [posfácio], 1943/1973, p.247

${ }^{208}$ Heidegger, Sobre o humanismo 1973, p.352
} 
seu ser (west) que ele é a 'aí', isto é, a clareira do ser." ${ }^{209}$ Estar inserido na clareira do ser, faz do homem o único ente a possuir linguagem ${ }^{210}$, uma vez que "linguagem é advento iluminador-velador do próprio ser." ${ }^{211}$ E por isso, também, ele seria o único ente que poderia pensar.

O homem é o ente que sustenta o Dasein como ec-sistente, tomando sob seu cuidado o aí, enquanto a clareira do ser e assim, sustenta o próprio Dasein ${ }^{212}$. Sustentar o Dasein seria tomar sob seu cuidado o Da, não sustentá-lo seria viver no descuido decaído como se não fosse Dasein. Por ser o ente exposto à verdade do ser, ele ec-siste e assim, sustenta o Dasein. O que Heidegger parece acenar é para a possibilidade de "levar a essência do homem a atentar, com seu pensar, para a dimensão da verdade do ser" ${ }^{213}$. E assim ele continua, "isto [levar a essência do homem à verdade do ser] só poderia acontecer em favor da dignidade do ser e em benefício do Dasein, que o homem, ec-sistindo, sustenta". ${ }^{214}$ Para atingirmos a verdade e a dignidade do ser, devemos esclarecer [de uma vez] como o ser se dirige ao homem e como o requisita. Heidegger retoma a frase de Ser e tempo "a 'substância' do homem é a ec-sistência" e nos descreve que tradicionalmente pensou-se "a ec-sistência do homem é sua substância." Mas como já mostrado em Ser e Tempo, o humano não se mostra de maneira atemporal a partir de um modo de ser substancial, mas ele é marcado pelo caráter de poderser-em-um-mundo. Deste modo, Heidegger acrescenta: a frase "não diz outra coisa que: o modo como o homem se presenta em sua própria essência ao ser é a ec-stática in-sistência na verdade do ser."215 O que está em jogo com seu caráter de poder-ser e com a ec-stática in-sistência na verdade do ser não é rejeitar as interpretações humanísticas do homem, mas pensar que elas acabam por não "experimentar a dignidade propriamente dita do homem." ${ }^{216}$ Heidegger, então se posiciona e nos diz que já em Ser e Tempo havia um contra humanismo, pois o pensamento tradicional ainda não pensou a humanitas do homem de modo suficientemente alto $^{217}$. Respondendo, de uma vez, pela dignidade do homem, o

\footnotetext{
${ }^{209}$ Heidegger, Sobre o humanismo 1973, p.353

${ }^{210}$ Heidegger, Sobre o humanismo 1973, p.354

${ }^{211}$ Heidegger, Sobre o humanismo 1973, p.354

${ }^{212}$ Heidegger, Sobre o humanismo 1973, p.354

${ }^{213}$ Heidegger, Sobre o humanismo 1973, p.355

${ }^{214}$ Heidegger, Sobre o humanismo 1973, p.355

${ }^{215}$ Heidegger, Sobre o humanismo 1973, p.355

${ }^{216}$ Heidegger, Sobre o humanismo 1973, p.355 (Grifado nosso)

${ }^{217}$ Heidegger, Sobre o humanismo 1973, p.356
} 
autor deixa claro que a essência do homem não seria a substância do ente como seu sujeito, o modo como o ente se presenta e ausenta não decide o homem, mas o que está em jogo é o modo como o ente penetra na clareira do ser. "O advento do ente repousa no destino do ser." ${ }^{218} \mathrm{O}$ homem é aquele [o único ente] que correspondendo à verdade do ser, penetrando em sua clareira, ele a vigia e a protege, sendo assim, o pastor do ser $^{219}$. É interessante notar que Heidegger traça um paralelo entre este pastorear o ser cuja responsabilidade é do homem e a existência experimentada como cuidado (Sorge) em Ser e Tempo, ou seja, como ser resoluto antecipador. Nas palavras do autor: "o homem é o pastor do ser. É somente nesta direção que pensa Ser e Tempo, quando é experimentada a existência ecstática como "o cuidado"(vide $\$ 44$, p.266 ss.)."220

Existe assim, uma proximidade entre Ser e homem cuja relação é essencial para Heidegger, uma vez que para pensar o ser, para pensar a questão acerca do ser, o homem é o ente que permitiria tal acesso, pela proximidade, pela pertença que culmina em seu privilégio ôntico-ontológico, já atestado em Ser e tempo. Dessa forma, o autor alemão vai retomar esta proximidade e assim nos descreve que apesar de parecer mais distante, o ser é o mais próximo. O mais próximo como aquele para o qual o homem se atém primeiro, é o ente, como descrevemos em Ser e tempo. Mas o ater-se primeiro ao ente é, na verdade, o mais distante e o mais próximo do próximo é o ser, a proximidade mesma é a verdade do $\operatorname{ser}^{221}$ na qual o homem está sempre posto. Parece ser nesse sentido que Heidegger em Seminários de Zollikon (seminário de 1964) nos esclarece "os fenômenos ontológicos são, pois, hierarquicamente os primeiros, mas, para serem pensados e vistos, são posteriores." 222 A partir deste esclarecimento de proximidade e distanciamento já apresentados antes, o autor retoma os termos inautenticidade (impróprio) e autenticidade (próprio) explorados em Ser e tempo e compreendidos erroneamente como uma filosofia moral ou antropológica. $\mathrm{O}$ autor, então nos adverte que o que está em jogo nestes termos é a própria relação ec-stática do ser humano com a verdade do ser, sendo a dimensão ôntica - inautêntica - a pretensamente mais próxima de nós, mas na verdade é a mais distante e a

\footnotetext{
${ }^{218}$ Heidegger, Sobre o humanismo 1973, p.356

${ }^{219}$ Heidegger, Sobre o humanismo 1973, p.356

${ }^{220}$ Heidegger, Sobre o humanismo 1973, p.356

${ }^{221}$ Heidegger, Sobre o humanismo 1973, p.357

${ }^{222}$ Heidegger, Seminários de Zollikon, 2001, p.36
} 
dimensão ontológica sendo a mais próxima do próximo, pois diz respeito à própria essência do Dasein humano. Assim, a decadência inautêntica descrita na obra Ser e tempo nada mais é do que o estar posto em relação ao ser no modo da inverdade, no modo do esquecimento do $\operatorname{ser}^{223}$, no modo do esquecimento do que nos é mais próximo e próprio, no modo da desumanização.

O mais essencial nesta relação com o ser que é a essência do homem, não é o homem propriamente dito, mas o ser, como a dimensão do elemento ec-stático da ec-sistência ${ }^{224}$. O ser é o que se dá, também já descrito em Ser e tempo ${ }^{225}$, o que está em jogo neste dar-se é o próprio destino do ser, "cuja história se manifesta na linguagem pela palavra dos pensadores essenciais. ${ }^{226}$ Por isso, o pensar seria historial, diz respeito à história do ser e a sua relação junto aos homens como àqueles que são determinados por esta história, este destino, este pensar e esta linguagem - do ser. Em Ser e tempo fala-se somente enquanto o Dasein é, dá-se ser, isto significa "somente enquanto se manifesta a clareira do ser, este se transporta ao homem." 227 Tal manifestação da clareira é a destinação do próprio ser que se transporta ao homem. Tal manifestação acontece a partir do projeto ec-stático que é projeto lançado, jogado pelo próprio $\operatorname{ser}^{228}$. O homem está nesta condição de jogado (lançado) como pastor do ser ${ }^{229}$, ele mora nesta proximidade, nesta clareira do ser, uma vez que ele está sem morada, ele está apatriado, pois esqueceu o ser. Heidegger toma o termo pátria a partir da conferência sobre a elegia de Hölderlin "Retorno", onde este, segundo o autor, estaria pensando um reencontro com o lugar essencial, "a partir da condição de fazerem parte do Ocidente. ${ }^{230}$ Entendendo este ocidente não como oposto ao oriente, nem como Europa, mas como "perspectiva da história universal a partir da proximidade com a origem." 231 Origem é pensada aqui como o essencial, como a pátria da morada histórica, sendo a própria proximidade do ser. Só experimentando a verdade do ser, isto é, esta proximidade, se poderia superar a

\footnotetext{
223 "O esquecimento da verdade do ser, em favor da agressão do ente impensado em sua essência, é o sentido da "decadência" nomeada em Ser e Tempo." (Heidegger, Sobre o humanismo 1973, p.357)

${ }^{224}$ Heidegger, Sobre o humanismo 1973, p.357

${ }^{225}$ Heidegger, Sobre o humanismo 1973, p.357

${ }^{226}$ Heidegger, Sobre o humanismo 1973, p.358

${ }^{227}$ Heidegger, Sobre o humanismo 1973, p.359

${ }^{228}$ Heidegger, Sobre o humanismo 1973, p.359

${ }^{229}$ Heidegger, Sobre o humanismo 1973, p.361-362

${ }^{230}$ Heidegger, Sobre o humanismo 1973, p.359

${ }^{231}$ Heidegger, Sobre o humanismo 1973, p.359 (Grifado nosso)
} 
apatricidade como este abandono do ser. Somos apatriados, pois só pensamos o ente, o ser como ente, e este abandono tornou-se desde a antiguidade um destino do mundo ${ }^{232}$. Por isso, Heidegger apontando a pátria está apontando para o caráter do homem morar na vizinhança do $\operatorname{ser}^{233}$, próximo ao ser. Este seria justamente o humanismo digno de ser pensado, aquele que pensa a humanidade do homem a partir da proximidade do ser, a partir da proximidade com a origem. O que Heidegger tem em mente não é de modo algum pensar o inumano e isto ele deixa claro ao longo do texto em diversos momentos, mas o importante seria abrir outras perspectivas ${ }^{234}$ acerca do pensar sobre o humano. Reconhecendo os limites da metafísica e com isto, das ciências e da psicologia, apontando outras perspectivas a partir do pensamento do ser. Não é à toa que este texto é de suma importância para pensarmos a relação com os homens a partir do pensamento de Heidegger. Junto a analítica existencial de Ser e tempo, constantemente retomada neste texto, vamos aos poucos compreendendo em que medida o autor abre um outro espaço para se pensar o que compreendemos por homem. Não mais a partir dos humanismos que tomariam o homem a partir de uma interpretação fixa desde o ponto de vista da conquista e dominação do ente na totalidade ${ }^{235}$, mas um humanismo que pudesse pensar a mais alta dignidade humana, ou seja, a partir de sua essência, de sua proximidade ao ser, de sua abertura ao ser. O homem está jogado, "postado 'na' abertura do ser" ${ }^{, 236}$, no mundo, como ec-sistente. Pensar o homem é pensar esta proximidade e, com isso, pensar o próprio ser. Por isso, Heidegger afirma: "pensar a verdade do ser significa, ao mesmo tempo: pensar a humanitas do homo humanus." ${ }^{237}$ Existe, assim, uma relação irredutível entre homem e ser, que é transpassada pelos elementos já apontados aqui tais como verdade, linguagem e pensar. Poderíamos talvez, dizer, que o

\footnotetext{
${ }^{232}$ Heidegger, Sobre o humanismo 1973, p.360

${ }^{233}$ Heidegger, Sobre o humanismo 1973, p.3362

${ }^{234}$ Heidegger, Sobre o humanismo 1973, p.364

${ }^{235}$ Heidegger, Sobre o humanismo 1973, p.351. Tal perspectiva seria característica do pensamento moderno e Heidegger deixa claro em seu texto $O$ tempo da imagem no mundo (1938). "Quanto mais abrangente e inexoravelmente o mundo estiver à disposição como conquistado, quanto mais objectivamente aparecer o objecto, tanto mais subjectivamente, isto é, tanto mais manifestamente se erguerá o subjectum, tanto mais irresistivelmente a consideração do mundo e a doutrina do mundo se transformará numa doutrina acerca do homem em antropologia. Não é de admirar que só onde o mundo se torna imagem surja o humanismo. Mas se não era possível, no grande tempo do mundo grego, qualquer coisa como uma imagem do mundo, então também não podia vigorar um humanismo." (Heidegger, O tempo da imagem no mundo, In. Caminhos de Floresta, 2002, p.116)

${ }^{236}$ Heidegger, Sobre o humanismo 1973, p.366 (Grifado nosso)

${ }^{237}$ Heidegger, Sobre o humanismo 1973, p.367 (Grifado nosso)
} 
pensamento e a prática psicológicos que queiram ser dignos do homem devem, segundo o pensamento heideggeriano, se aproximar do mais próximo - o ser. É interessante que é neste texto que Heidegger acena para a possibilidade de se pensar uma ética. Não vamos nos aprofundar no que poderia ser uma ética heideggeriana, mas sem dúvida ela estaria intimamente relacionada ao pensamento do ser, aos destinos historiais e a essência do homem como esta proximidade ao ser, o estar posto diante do ser, da abertura ao ser como um existente.

Foi possível, dessa forma, expormos a relação homem - pensar - linguagem - ser. Pensar um humanismo digno, um pensamento sobre o humano alto o suficiente e uma relação com o humano mais autêntica, só seria possível se partíssemos de sua (do homem) proximidade com o ser. O pensar que pensa é aquele que consuma a essência do homem junto à relação do ser, o pensar que pensa deposita o dizer do ser na linguagem. Heidegger parece assim fazer um apelo para que pensemos, meditemos sobre esta relação Ser-homem que, talvez, possa apenas ser sustentada e suscitada pela tomada do cuidado apontada em Ser $e$ tempo. O ser chega para a linguagem, onde habita o ser, com o pensar, um pensar (do ser) que sulca a linguagem. Sulca de modo quase invisível, destinal e historial a partir do dizer dos pensadores ${ }^{238}$. É a partir da compreensão da essência do (homem) humano e sua relação com a linguagem, verdade e destino do ser que o sub capítulo a seguir irá abordar um diálogo de Heidegger junto à psicoterapeutas com o intuito de repensar como seria possível compreender uma psicologia com base na analítica existencial e na relação humano-ser.

\section{3}

\section{Seminários de Zollikon: o diálogo direto com a psicologia}

O existir humano nunca é um objeto presente num lugar qualquer e não é um objeto encerrado em $\mathrm{si}^{239}$. É com esta sentença que Heidegger inicia seu seminário em 1959 que vai até 1969 junto a psicólogos e psiquiatras. Seu intuito era mostrar a eles o quanto as teorias psicológicas da época estariam assentadas sobre bases insuficientes para a compreensão do existir humano. Insuficientes, na

\footnotetext{
${ }^{238}$ Heidegger, Sobre o humanismo, 1973, p.372

${ }^{239}$ Heidegger, Seminários de Zollikon, 2001, p.33
} 
medida em que fecham o ser do homem em algo já dado, predicado, substancializado e muitas vezes, calculado e controlado por conexões causais. E por isso, o autor alemão nos diz: "todas as representações encapsuladas objetivantes de uma psique, um sujeito, uma pessoa, um eu, uma consciência, usadas até hoje na Psicologia e na Psicopatologia, devem desaparecer na visão Daseinsanalítica em favor de uma compreensão completamente diferente." 240 Daseinsanalise $^{241}$ seria a visão que leva em conta o existir humano a partir de sua íntima relação com o ser.

Desde Descartes o ser homem vem sido tomado como sujeito de representações e os objetos como coisas representadas. Tal concepção, característica da época moderna acabaria lidando com o humano de uma maneira pré-determinada e preconceituosa, na medida em que o ser-homem se determinou como sujeito de representações, consciente e dotado de faculdades tais e tais e o mundo como imagem, como totalidade destas representações. A concepção moderna do homem e do mundo é bem descrita por Heidegger em seu texto $O$ tempo da imagem no mundo (1938), neste o autor nos descreve que "toda a metafísica moderna, incluindo Nietzche, mantém-se na interpretação do ente e da verdade traçada por Descartes. " 242 Em outra passagem, ele acentua que "o homem [moderno] torna-se centro de referência enquanto tal. Mas isso só é possível quando se transforma a concepção do ente na totalidade." ${ }^{243}$ Para esclarecer ainda mais esta concepção moderna de interpretação do ente a passagem a seguir é fundamental:

Onde o mundo se torna imagem, o ente na totalidade está estabelecido como aquilo para o que o homem se prepara, como aquilo que por isso, correlativamente, ele quer trazer para e ter diante de si e, assim, pôr diante de si num sentido decisivo. Imagem do mundo, compreendida essencialmente, não quer, por isso, dizer uma imagem que se faz do mundo, mas o mundo concebido como imagem. $\mathrm{O}$ ente na totalidade é agora tomado de tal modo que apenas e só é algo que é, na medida em que é posto pelo homem representador-elaborador. Onde se chega à imagem do mundo, cumpre-se uma decisão essencial sobre o ente na totalidade. O ser do ente é procurado e encontrado no estar-representado do ente. Contudo, onde quer que o ente não seja interpretado neste sentido, o mundo também não poderá surgir na

\footnotetext{
${ }^{240}$ Heidegger, Seminários de Zollikon, 2001, p.33

${ }^{241}$ Como já explicitado em nota, esta pesquisa não vai dialogar com o que se entende por Daseinsanalise, visto que este texto se limitou a apresentar um diálogo entre o modo como Heidegger compreende o humano e o modo como Derrida compreende o humano. Bem como uma desconstrução derridiana acerca dos limites do pensamento heideggeriano.

${ }^{242}$ Heidegger, O tempo da imagem no mundo, In. Caminhos de Floresta, 2002, p. 110

${ }^{243}$ Heidegger, O tempo da imagem no mundo, In. Caminhos de Floresta, 2002, p.111
} 
imagem, não poderá haver nenhuma imagem do mundo [como é o caso do mundo grego $^{244}$ e do mundo medieval, por exemplo]..$^{245}$

As teorias psicológicas e aquelas que se voltam ao estudo do que se compreende por homem teriam, dessa forma, se sustentado nesta concepção de humano e de mundo, concepção esta que teria herdado, sobretudo, uma metodologia com base nas ciências naturais, onde os objetos são passíveis de representação em sua objetidade e caracterizados pela mensurabilidade ${ }^{246}$. A ciência teria tomado ser por ente, negligenciando por completo o mais fundamental: a questão acerca do sentido de ser. Questões estas já apontadas em sua obra Ser e tempo. O mais importante seria a diferenciação entre ser e ente. A existência dos homens teria como base esta diferenciação ${ }^{247}$. Base esta negligenciada pela psicologia e pela ciência. $\mathrm{O}$ autor alemão deixa claro que ele não tem o intuito de abandonar a ciência, o que está em jogo são os limites nos quais ela se mostra. Limites estes ainda inquestionados, uma vez que seu alargamento pressupõe a compreensão da abertura ao ser do ente e a compreensão da diferenciação entre ser e ente como a mais fundamental.

Heidegger observa a necessidade de se meditar sobre estes limites das ciências. Na medida em que, tomando ser por ente, as ciências visariam algo já dado, já determinado aprioristicamente e com isso uma restrição deste algo. No caso do humano, a determinação deste ente já seria dada antes mesmo dele existir. O que se perderia nisso seria o próprio ser do homem e seus modos possíveis de

\footnotetext{
${ }^{244}$ Para esclarecer a diferença entre o mundo e o homem grego e moderno, Heidegger nos descreve que na concepção grega "é o homem o que é contemplado pelo ente, o que é reunido pelo que se abre ao que, nele, vem-à-presença. Ser contemplado pelo ente, estar envolvido e retido no seu aberto e, assim, ser suportado por ele, estar enredado nas suas oposições e marcado pela sua discrepância: tal é a essência do homem, no grande tempo grego. Daí que este homem, para cumprir a sua essência tenha que reunir e salvar, apanhar e guardar aquilo que se abre no seu estaraberto, e permanecer exposto a toda esta confusão que se desintegra. O homem grego é enquanto aquele que percepciona o ente; daí que, no mundo grego, o mundo não se possa tornar imagem. [...] Diferenciando-se do percepcionar grego, o representar moderno, cujo significado é expresso aproximadamente pela palavra repraesentatio, quer dizer algo muito diferente. Re-presentar significa aqui trazer para diante de si o que-está-perante enquanto algo contraposto, remetê-lo a si, ao que representa, e, nesta referência, empurrá-lo para si como o âmbito paradigmático. Onde tal acontece, é o homem que, sobre o ente, se põe como imagem. Mas na medida em que o homem, deste modo, se põe como imagem, ele põe a si mesmo em cena, isto é, no círculo aberto do que é universal e publicamente representado. Com isso, o homem põe-se a si mesmo como a cena, na qual o ente doravante se tem de re-presentar presentificar [präsentieren], isto é, ser imagem. O homem torna-se no que representifica [Repräsentant] o ente, no sentido do que é objectivo." Heidegger, O tempo da imagem no mundo, In. Caminhos de Floresta, 2002, p.114-115

${ }^{245}$ Heidegger, O tempo da imagem no mundo, In. Caminhos de Floresta, 2002, p.112-113

${ }^{246}$ Heidegger, Seminários de Zollikon, 2001, p.124

${ }^{247}$ Heidegger, Seminários de Zollikon, 2001, p.45
} 
determinação. Á respeito da ciência contemporânea que busca apontar a necessidade de certeza, controle e segurança, Heidegger nos questiona "o que se pode calcular de antemão, antecipadamente, o que pode ser medido é real e apenas isso. Até onde isto nos leva perante uma pessoa doente? Fracassamos!"248 Relacionar-se a partir do cálculo e da mensurabilidade, quais os limites dessa relação na compreensão do humano? Do doente? Da loucura?

O Dasein não pode ser compreendido a partir da objetivação, mas ele é o ente que se mantém aberto em "um âmbito de poder-apreender as significações daquilo que aparece e que se lhe fala a partir da clareira." ${ }^{249}$ O que estaria em jogo na objetivação do homem seria a admissão do ser humano como conexão causal e explicável perante os demais. Para Heidegger, tomar o homem como objeto, como coisa seria justamente deixar escapar a própria existência do humano em detrimento de um modo restrito de apreensão dele.

Podemos perceber que a crítica de Heidegger nos leva a pensar que com base na ciência moderna, a psicologia teria tomado o homem também como objeto, algo presente adiante da mão e, com isso teria negligenciado a pergunta de como e o que determina o homem como homem ${ }^{250}$, esquecendo-se da própria essência do homem. Segundo o autor, a mensuração característica deste pensamento (da ciência moderna) só é possível quando a coisa é pensada como objeto e representada em sua objetidade. Na ciência moderna o sujeito coloca a si mesmo como objeto e a verdade como certeza e objetividade. Uma vez que esta concepção busca assegurar-se da previsibilidade da natureza, incluindo o próprio humano como objeto desta previsibilidade. A natureza, o homem, poderíamos dizer tudo o que se mostra, já é colocado como objeto de uma previsibilidade universal. A "verdade não significa aqui, pois, manifestação [Offenbarkeit] do diretamente presente; a verdade é definida como aquilo que pode ser verificado de modo claro, óbvio, seguro e indubitável, isto é, certo para o eu que representa."251 O critério desta verdade como certeza seria a evidência que alcançamos quando chegamos ao indubitável $^{252}$ e aqui Heidegger deixa claro que está dialogando com Descartes. Então ele nos pergunta, mas seria o medir passível de mensuração? O

\footnotetext{
${ }^{248}$ Heidegger, Seminários de Zollikon, 2001, p.47

${ }^{249}$ Heidegger, Seminários de Zollikon, 2001, p.33

${ }^{250}$ Heidegger, Seminários de Zollikon, 2001, p.176

${ }^{251}$ Heidegger, Seminários de Zollikon, 2001, p.132

${ }^{252}$ Heidegger, Seminários de Zollikon, 2001, p.132
} 
próprio medir não teria sido colocado em xeque ${ }^{253}$. E ainda, em que medida, podemos mensurar tudo? Como medir as lágrimas? ${ }^{254} \mathrm{Ou}$ a tristeza? ${ }^{255} \mathrm{Se}$ há coisas que não podem ser medidas, a mensuração torna-se impertinente ${ }^{256}$.

A partir do que Heidegger parece nos propor e ao mesmo tempo nos alertar vamos dar ênfase aos seguintes pontos que nos dizem respeito aqui:

- A pretensão das ciências naturais e consequentemente as práticas e teorias psicológicas nela assentada, "a ciência como tal não é rejeitada de nenhuma maneira. Só a sua pretensão ao absoluto, a ser o parâmetro de todas as verdades, é julgada pretensiosa" ${ }^{257}$;

- A ameaça do ser-homem do homem ocidental poder sucumbir ${ }^{258}$,

- A possibilidade de abrir outros caminhos do ente de maneira diferente ${ }^{259}$; não mais limitando e reduzindo a presença do ente à sua relação com o homem que representa no sentido de objetidade.

Para nos aproximarmos dessas questões que Heidegger nos chama a atenção, precisamos entender a mensurabilidade, o objeto e o sujeito a partir da história do pensamento, uma vez que a objetidade é uma certa modificação da presença $^{260}$ (do ser) das coisas. A presença não é mais tomada como o que é dado a partir de si mesmo (como nos gregos), mas como aquilo que se contrapõe a mim como sujeito pensante, como é objetivado para dentro de mim. Descartes teria chegado a sua posição a partir da vontade de construir algo seguro e não a partir de uma relação fundamental direta com aquilo que é ou com a questão do ser. Para Heidegger, ele estaria numa oposição com a concepção grega ${ }^{261}$. "O traço fundamental correspondente do método grego é a conservação e a "salvação" dos

\footnotetext{
${ }^{253}$ Heidegger, Seminários de Zollikon, 2001, p.134

${ }^{254}$ Heidegger, Seminários de Zollikon, 2001, p.108

${ }^{255}$ Heidegger, Seminários de Zollikon, 2001, p.109

${ }^{256}$ Heidegger, Seminários de Zollikon, 2001, p.166

${ }^{257}$ Heidegger, Seminários de Zollikon, 2001, p.136

${ }^{258}$ Heidegger, Seminários de Zollikon, 2001, p.129

${ }^{259}$ Heidegger, Seminários de Zollikon, 2001, p.133

260 "Presença é a determinação do ser do ente desde a antiguidade." (Heidegger, Seminários de Zollikon, 2001, p.196) Nós não vamos nos debruçar sobre como Heidegger compreende estas modificações do ser dos entes, da presença, da antiguidade até hoje. É importante termos em mente o que está em jogo para ele e como estas modificações aparecem em seu pensamento relacionada ao papel do humano em suas obras. Reconhecemos a necessidade de um estudo mais aprofundado das épocas Heideggerianas, seus motivos e suas derivações, mas isso não será desdobrado aqui. Uma vez que precisamos delimitar e seguir com nosso tema: a compreensão do homem para Heidegger, seu caráter existencial como abertura ao ser em contraposição aos limites das teorias tradicionais acerca do humano.

${ }^{261}$ Heidegger, Seminários de Zollikon, 2001, p.136
} 
fenômenos que se mostram, deixados intocados e incólumes, o puro deixar-estarpresente daquilo que se mostra." ${ }^{262}$ Não haveria objeto nem sujeito na idade média tampouco na antiguidade grega, Heidegger já havia deixado isto claro em sua obra "O tempo da imagem no mundo". A experiência de algo presente na Grécia se dava como algo que brota a partir de si e em si mesmo (phisis) ${ }^{263}$. O que teria mudado dos gregos até agora? "Trata-se aqui só de uma mudança do uso da linguagem? Não. Trata-se de algo inteiramente diferente. Nada menos do que uma mudança radical da posição do homem diante do ente. ${ }^{, 264}$ Em outra passagem ele também nos esclarece: "A ciência moderna é baseada nesta mudança da experiência da presença do ente para a objetidade." 265

Mas como podemos compreender melhor esta posição diante do ente? Seria esta posição a própria essência do que se compreende por ser-homem? Seria esta a característica fundamental do Dasein, daquilo que compreendemos por homem? O ser humano é justamente esta abertura para o ente, para o ser do ente, no desocultamento do que está presente. Com relação ao lidar dos médicos, psiquiatras e psicólogos, Heidegger nos adverte que é importante que entendamos que "existem numerosos modos de presença daquilo que se dirige ao Dasein a partir do aberto de seu mundo. [...] O ser só pode ser experienciado em e pela presença de um ente". ${ }^{266}$ O que o autor alemão parece ter em mente seria chamar a atenção para o caráter de abertura característico do existir. É justamente por ser aberto que algo pode ser liberado para ser como algo. O uso (Gebrauch) deste algo liberaria a mesa como mesa, por exemplo. "O através do qual algo aparece e se mostra à sua maneira, é o aberto, o livre."267

Vai ficando mais claro em que medida a abertura ao ser, ao ser de um ente, que torna presente o ente, é fundamental para compreendermos a essência do Dasein humano. Estando aqui, que é um estar-lá, torno presente, executo o tornar presente e tenho por essência um estar junto aos entes. "Este 'estar junto de' do nosso estar aqui junto das coisas tem o traço fundamental do estar-aberto para a coisa presente, com que se está. [...] O estado de abertura para o presente é o

\footnotetext{
${ }^{262}$ Heidegger, Seminários de Zollikon, 2001, p.136

${ }^{263}$ Heidegger, Seminários de Zollikon, 2001, p.124

${ }^{264}$ Heidegger, Seminários de Zollikon, 2001, p.144 (Grifado nosso)

${ }^{265}$ Heidegger, Seminários de Zollikon, 2001, p.126

${ }^{266}$ Heidegger, Seminários de Zollikon, 2001, p.175 (fala de Heidegger taquigrafada por Medard Boss)

${ }^{267}$ Heidegger, Seminários de Zollikon, 2001, p.37 (vimos esta liberação de algo como algo também em Ser e tempo a partir da totalidade conjuntural)
} 
traço fundamental do ser humano. Mas o estado de abertura para o ente traz em si diversas possibilidades. ${ }^{, 268}$ Este estado de abertura do homem para o ente é fundamental para a compreensão do ser-homem e passa despercebido pelas teorias psicológicas $^{269}$. Sem a interpelação pelo ente na abertura do Dasein, o homem não existiria. Isso significa que um stress, exemplo trabalhado por Heidegger nesta obra (mas podemos pensar qualquer dito sintoma, patologia ou distúrbio) só poderia surgir a partir do existente como ser aberto e interpelado por (um ente). A interpelação do ente se dá no mundo em que ele está cotidianamente.

Fica cada vez mais claro, que Heidegger, nestes seminários, busca chamar a atenção para o estado de abertura do Dasein ao ser do ente e suas diversas possibilidades de essencialização e determinação na história do ser. Como vimos, "a história do ser sustenta e determina cada condition e situation humaine." ${ }^{270} \mathrm{E}$ "O advento do ente [todo ente, inclusive o homem] repousa no destino do ser."271 Se nestes seminários ele não se debruça completamente sobre os destinos do ser, não podemos dizer que ele tampouco os ignora. Como já apontado em nota, esta pesquisa não vai desmembrar a temática heideggeriana sobre os destinos do ser, mas ao mesmo tempo nós também não podemos passar como se ela não nos (nós - Dasein aberto ao ser) dissesse respeito. A analítica do Dasein fundamentada, sobretudo na compreensão de ser deste ente está em última instância determinada pela história do ser.

Na história da determinação do ente teríamos 3 estágios: 1. ser do ente como [hipokeimenon] - que consiste naquilo que brota a partir de si mesmo e o fabricado pelo homem [Antiguidade grega]; 2. o ser do ente como possibilidade de criação [Geschoepflichkeit] [Idade média]; [e] 3. o objeto [objekt] ou o objeto [Gegenstand] determinado pelo eu-sujeito [Modernidade]. ${ }^{272}$

A historicidade humana pertence ao destino do ser na medida em que o Dasein humano em sua essência é relação com o ser, abertura ao ser, nesse sentido, é clara a determinação humana a partir da história do ser. O que hoje se compreende pelo ser do homem não foi o mesmo na idade média, nem na grega. O ser do homem seria sustentado e determinado pela história do ser. Medard Boss taquigrafou testemunhos de Heidegger e em um deles, o autor nos esclarece:

\footnotetext{
${ }^{268}$ Heidegger, Seminários de Zollikon, 2001, p.100 (Grifado nosso)

${ }^{269}$ Heidegger, Seminários de Zollikon, 2001, p.101

${ }^{270}$ Heidegger, Sobre o humanismo 1973, p.347

${ }^{271}$ Heidegger, Sobre o humanismo 1973, p.356

${ }^{272}$ Heidegger, Seminários de Zollikon, 2001, p.145 (ver também p.143) - seminário de 23/11/1965.
} 
A determinação da essência de qualquer coisa compõe-se de três determinações. Primeiramente, é necessária a determinação daquilo como o que algo é. Em relação ao Da-sein humano, a resposta é: como ser-no-mundo, como se relacionar com o que está presente. Sob este título cabe a descrição para que se possa saber na verdade, do que se trata. À segunda sub-determinação refere-se à condição da possibilidade de ser assim. Aplicada ao Da-sein esta condição da possibilidade de ser como Da-sein é: a compreensão do ser. A terceira sub-determinação refere-se àquilo em que esta condição da possibilidade está fundada por sua vez: em relação ao Da-sein humano: no destino do ser. Se não fosse destinado ser ao Da-sein, também não haveria compreensão do ser. ${ }^{273}$

É interessante que esta obra, um tanto quanto negligenciada no campo da filosofia, trabalha em cima de seminários construídos, pensados e revisados pelo autor ao longo de mais de dez anos. É assim que Boss nos conta na passagem a seguir,

eu mesmo [Boss] transcrevi palavra por palavra cada afirmação de Martin Heidegger, imediatamente depois ditava o texto taquigrafado para um gravador e minha secretária datilografava-o. $\mathrm{O}$ texto era então enviado regularmente a $\mathrm{M}$. Heidegger em Friburgo. Ele o corrigia com o maior cuidado, acrescentava aqui e ali pequenas, às vezes, também maiores observações em sua letra gótica e o devolvia para mim assim, corrigido e complementado. Finalmente, eu mandava imprimir os registros pela própria mão de Martin Heidegger, e, com isso, plenamente autorizados e passados a limpo, eram encaminhados a cada seminarista [...] Entre os seminários sobravam a Martin Heidegger e a mim muitas horas para amplas conversas a dois. Com o tempo, tive a ideia de taquigrafar também esses depoimentos de Martin Heidegger. [...] Esta coleção forma a segunda parte deste livro. ${ }^{274}$

Nesse sentido, esta obra abarca o pensamento de Heidegger já nos seus últimos anos, mas retoma constantemente a obra Ser e tempo como fundamental para pensar o Dasein humano relacionando sua analítica a temas tardios no pensamento do autor alemão, tais como: os destinos do ser e a linguagem do ser. Nós não vamos adentrar a fundo em todos os temas do pensamento tardio de Heidegger, não vamos nos debruçar sobre a problemática da interpretação do ser como a incondicional vontade da subjetividade cuja hegemonia marcaria toda a modernidade, ao menos de Descartes à Hegel e à Nietzsche. Mas nossa problemática mais do que descrever como Heidegger compreende a subjetividade nas épocas, ou nas vozes da época como uma afirmação da vontade como forma de interpretação do ser, é descrever e pensar o papel do humano em seu pensamento, a relação do homem com o existir e com sua abertura em

\footnotetext{
${ }^{273}$ Heidegger, Seminários de Zollikon, 2001, p.233-234 (Grifado nosso)

${ }^{274}$ Boss M., Prefácio à primeira edição, In. Heidegger, Seminários de Zollikon, 2001, p.12-14 (Grifado nosso)
} 
contraposição ao fechamento e ao preconceito da tradição e da ciência, sobretudo da psicologia, acerca do pensar e do se relacionar com o humano.

O tema da linguagem também trabalhado em carta Sobre o humanismo é aqui retomado e relacionado novamente ao Dasein humano. A linguagem do ser falaria ao homem a partir do estar aberto ao ente, do "é" do ente como ente, que pode se mostrar de múltiplos modos. Heidegger nos descreve: "o homem diferencia-se do animal apenas por poder “dizer", isto é, por ter uma linguagem. [...] o falar humano é um dizer." ${ }^{275} \mathrm{O}$ dizer torna visível algo, ele mostra, deixa ver "é um deixar ver do ente como um ente sendo assim e assim. O ser humano está, pois, na abertura do ser, no desocultamento do que está presente. Este é o fundamento para a possibilidade, e mesmo para a necessidade, para a essencial necessidade do dizer; para o fato de que o homem fala." ${ }^{276} \mathrm{O}$ deixar mostrar do dizer passa sempre pela linguagem. A interpelação do ente que vem ao encontro já é pré-delineada na linguagem ${ }^{277}$. Através dela já pré-compreendo isso ou aquilo. Linguagem é a abertura de "diversas maneiras pelo homem, daquilo que é."278 Fica um pouco mais clara a relação da linguagem com ser e com a essência do Dasein na passagem a seguir:

Ser-lançado e compreensão co-pertencem mutuamente numa união [fazem parte da abertura do Dasein], cuja unidade é determinada pela linguagem. Linguagem deve ser pensada aqui como dizer [Sagen], no ente como ente, quer dizer, a linguagem se mostra com referência ao ser. Somente baseado na unidade de ser lançado e compreensão pela linguagem como tradição [Sage] é que o homem é interpelável pelo ente em geral. ${ }^{279}$

Em seguida Heidegger, ainda com relação ao exemplo do stress nos diz que "o stress [e podemos pensar outros modos de ser do existente] situa-se na existência humana determinada pelo ser lançado, pela compreensão e a linguagem [do ser]." ${ }^{280}$ Talvez fique um pouco mais clara a passagem taquigrafada de Medard sobre a possibilidade de determinação da essência de algo, que dependeria do Dasein, como ser-no-mundo (ser-lançado no mundo ${ }^{281}$ ), da

\footnotetext{
${ }^{275}$ Heidegger, Seminários de Zollikon, 2001, p.115

${ }^{276}$ Heidegger, Seminários de Zollikon, 2001, p.117 (Grifado nosso)

${ }^{277}$ Heidegger, Seminários de Zollikon, 2001, p.157

${ }^{278}$ Heidegger, Seminários de Zollikon, 2001, p.165

${ }^{279}$ Heidegger, Seminários de Zollikon, 2001, p.165

${ }^{280}$ Heidegger, Seminários de Zollikon, 2001, p.166

${ }^{281}$ Passagem esclarecedora: "O homem é e é homem enquanto é o ec-sistente. Ele está postado, num processo de ultrapassagem, na abertura do ser, que é o modo como o próprio ser é; este jogou [lançou] a essência do homem, como um lance, no "cuidado" de si. Jogado [lançado] desta maneira, o homem está postado "na" abertura do ser. "Mundo" é a clareira do ser na qual o homem
} 
compreensão de ser como essência deste ente, e a linguagem do ser em que o ser fala e se destina aos homens. Novamente a passagem abaixo:

A determinação da essência de qualquer coisa compõe-se de três determinações. Primeiramente, é necessária a determinação daquilo como o que algo é. Em relação ao Da-sein humano, a resposta é: como ser-no-mundo [ser lançado em um mundo], como se relacionar com o que está presente. Sob este título cabe a descrição para que se possa saber na verdade, do que se trata. À segunda sub-determinação referese à condição da possibilidade de ser assim. Aplicada ao Da-sein esta condição da possibilidade de ser como Da-sein é: a compreensão do ser. A terceira subdeterminação refere-se àquilo em que esta condição da possibilidade está fundada por sua vez: em relação ao Da-sein humano: no destino do ser [destino da linguagem do $\operatorname{ser}^{282}$. Se não fosse destinado ser ao Da-sein, também não haveria compreensão do ser. ${ }^{283}$

E como pensarmos a maneira de se relacionar e de pensar acerca dos humanos? Em Ser e tempo, a metodologia para a própria analítica existencial, base da ontologia fundamental, era a fenomenologia. Nesta obra, ela é retomada no seminário em 1965 como a visão que constituiria $a$ contribuição fundamental $^{284}$ às pesquisas fisio-psicológicas. Em outra passagem o autor nos descreve "precisamos aprender a desviar da maneira de representar científicanatural e psicológica e abordar o modo de pensar fenomenológico. Este último exige, ao mesmo tempo, que conservemos a visão da tradição ${ }^{285}$,", uma vez que ela marca as determinações consideradas naturais. Como a passagem acerca do círculo hermenêutico em Ser e tempo, em que ele nos descreve que "o decisivo não é sair do círculo, mas nele penetrar de modo correto [rechten]. ${ }^{, 286}$ A maneira positiva de adentrar neste círculo seria, como vimos, não deixar que o prévio seja dado por ocorrência e conceitos populares [da tradição], mas assegurar a ciência a partir das coisas elas mesmas ${ }^{287}$ [utilizando o método fenomenológico das coisas elas mesmas]. A fenomenologia vai falar do que se mostra, ela pede apenas que vejamos este mostrar, sem conclusões precipitadas e sem reconduzi-los a qualquer coisa, devemos evitar relacioná-los, considerando os fenômenos em seu próprio

penetrou na condição de ser-jogado [lançado] de sua essência. O "ser-no-mundo" nomeia a essência da ec-sistência, com vistas à dimensão iluminada, desde a qual desdobra seu ser o "ec" da ec-sistência." (Heidegger, Sobre o humanismo, 1973, p.366)

282 "É a linguagem a casa do ser manifestada e apropriada pelo ser e por ele disposta." (Heidegger, Sobre o humanismo, 1973, p.357) Em outra passagem, "O ser é como o destino do pensar. O destino, porém, é em si historial. Sua história já chegou à linguagem, no dizer dos pensadores." (Heidegger, Sobre o humanismo, 1973, p.372)

${ }^{283}$ Heidegger, Seminários de Zollikon, 2001, p.233-234

${ }^{284}$ Heidegger, Seminários de Zollikon, 2001, p.102

${ }^{285}$ Heidegger, Seminários de Zollikon, 2001, p.86

${ }^{286}$ Heidegger, Ser e Tempo, 2012, p.433

${ }^{287}$ Heidegger, Ser e Tempo, 2012, p.433 
conteúdo e essência ${ }^{288}$. Justamente por que o fenômeno está relacionado ao que se mostra, é que podemos dizer que ele só pode se mostrar no âmbito da linguagem ${ }^{289}$. Na medida em que mostrar é dizer e algo só pode ser dito através da linguagem, que é linguagem do ser. O que Heidegger tenta nos chamar a atenção é para a cegueira diante dos fenômenos, onde o pensamento das ciências humanas herdado pelo pensar moderno calcula e mensura sem visão contando com os efeitos para dominação e controle. E não é isso que de certa forma acontece no campo da psicologia? Cada vez mais queremos dominar e controlar o dito humano, determinando e delimitando o que ele é, o que pode ser e como se mostra. Assim acontece com os humanos ditos normais, mas também com as patologias e distúrbios psicológicos. O que acaba se perdendo é o próprio fenômeno em questão. Por isso, ele nos descreve que "apenas uma coisa importa, aceitar simplesmente aquilo que se mostra no fenômeno do tornar presente e nada a mais., 290

Heidegger aos poucos nos descreve a partir de determinados modos de ser dos homens, como o fechamento e a restrição da visão científico natural não poderia compreender o fenômeno em questão. E assim nos apresenta direções para as quais o saber psicológico poderia se encaminhar. O que estaria em jogo numa relação com um homem triste, por exemplo? Não poderia ser o cálculo nem a mensuração de sua tristeza, buscando controlar os efeitos dela sobre o próprio homem, mas sim o modo como este homem triste é solicitado e como sua relação consigo mesmo e com o mundo estaria modificada ${ }^{291}$. Ou seja, o importante seria pensar o modo como o humano é interpelado e como ele se relaciona com este modo de interpelação. Em outra passagem, o autor nos descreve a direção para onde o saber psicológico poderia caminhar, acentuando, dessa forma, a importância dos que se relacionam com os humanos enfermos de se situarem historicamente.

Quem se dedica hoje em dia à profissão de ajudar as pessoas psiquicamente enfermas, deve saber o que acontece; deve saber onde está historicamente; precisa esclarecer-se diariamente que aqui está operando um destino antigo do homem europeu; ele precisa pensar de maneira histórica e abandonar a absolutização

\footnotetext{
${ }^{288}$ Heidegger, Seminários de Zollikon, 2001, p.113

${ }^{289}$ Heidegger, Seminários de Zollikon, 2001, p.91

${ }^{290}$ Heidegger, Seminários de Zollikon, 2001, p.101

${ }^{291}$ Heidegger, Seminários de Zollikon, 2001, p.109
} 
incondicional do processo em cujo rastro o ser-homem do homem ocidental ameaça sucumbir. ${ }^{292}$

É neste sentido que ele nos diz que "só no diálogo com a tradição esclarecem-se as questões, freia-se o arbítrio." ${ }^{293}$ Uma escolha livre, como se compreenderia tradicionalmente o livre arbítrio, por exemplo, escolhe entre A e B, sem levar em consideração o caráter histórico da possibilidade de colocação destas escolhas. Mas um mundo, um campo histórico específico já nos diria as escolhas que podemos tomar, ou seja, o campo histórico é que torna possível a escolha entre A e B. Dessa forma, um diálogo com a tradição é de alguma forma, compreender o destino histórico que está operando, no qual estaríamos inseridos. Pensar, é pensar este destino histórico, este destino do ser. Fica mais claro talvez, quando descrevemos que o ser chega para a linguagem, morada do ser, com o pensar, um pensar (do ser) que sulca a linguagem. Sulca de modo quase invisível, destinal e historial a partir do dizer dos pensadores ${ }^{294}$. Dialogar com a tradição seria de certo modo ouvir o dizer dos pensadores, que falam a partir história do ser. Isso seria pensar de maneira histórica, levando em conta o destino antigo que se opera no ocidente. Por isso Heidegger nos diz que é raro um médico que pensa $^{295}$ e que não esteja disposto a dar lugar aos técnicos científicos. Àqueles herdeiros da ciência moderna que se deixada a seu destino culminará na autodestruição do homem ${ }^{296}$.

Em passagens taquigrafadas por Medard Boss vemos a tentativa de Heidegger em se aproximar, ainda que de maneira breve, da práxis psicológica. $\mathrm{O}$ autor alemão fala da compreensão das alucinações e de sua necessidade em compreender o mundo em que o paciente se encontra, sem ficar diferenciando o "real" do "irreal" ${ }^{297}$. Acentua também a necessidade do querer médico estar voltado para o existir como abertura ao ser, relação com o ser e não para o alcance de objetivos ${ }^{298}$, como acontece com os saberes psicológicos baseados na ciência moderna. Tomar o homem como objeto de um saber científico é ter o homem como algo mais polido, como uma máquina e não um homem mais sadio. Por fim

\footnotetext{
${ }^{292}$ Heidegger, Seminários de Zollikon, 2001, p.129 (Grifado nosso)

${ }^{293}$ Heidegger, Seminários de Zollikon, 2001, p.63

${ }^{294}$ Heidegger, Sobre o humanismo, 1973, p.372

${ }^{295}$ Heidegger, Seminários de Zollikon, 2001, p.129

${ }^{296}$ Heidegger, Seminários de Zollikon, 2001, p.121

${ }^{297}$ Heidegger, Seminários de Zollikon, 2001, p.176

${ }^{298}$ Heidegger, Seminários de Zollikon, 2001, p.180
} 
acentuamos que o autor alemão sugere a necessidade do próprio pesquisador experienciar a si mesmo como Da-sein, só assim poderá ter êxito e iluminar toda a pesquisa do ser humano sadio e doente ${ }^{299}$.

Vai ficando cada vez mais claro o modo como Heidegger compreende o humano e em que medida a abertura ao ser e a relação com o ser características essenciais da existência são base para colocar os limites, repensar e destruir o modo como ciências tradicionais, inclusive as psicológicas, lidariam com o homem até hoje. Ao buscar alargar tais limites, Heidegger repensa o humano e o modo como podemos nos relacionar com ele, a partir de sua existência (relação: Dasein humano - Ser; como irredutível). Este alargamento não seria uma substituição de um modo de pensar por outro, mas acena para toda uma reconfiguração nesta lida, uma vez que, o mundo, a linguagem, a verdade, a relação, os homens e as coisas passam a ser pensadas a partir desta relação SerDasein, a partir da abertura ao ser e da existência como essência fundamental deste ente.

\section{4 \\ Diferença ontológica}

Como pudemos ver a diferença ontológica de Heidegger em sua obra Ser e tempo está assentada sobre o Dasein, uma vez que este é o ente privilegiado ôntico-ontológico que pode compreender o ser dos entes. A partir deste privilégio o Dasein passa a ser responsável pela transformação de mundo. Com os anos, a diferença - entre ser e ente - acaba sendo deslocada também para o mundo, retirando do autêntico (próprio) Dasein a responsabilidade para as transformações e para a abertura de novos caminhos. Neste sentido, torna-se importante tentarmos nos debruçar sobre o que Heidegger chamará de diferença após este deslocamento, uma vez que o que é perseguido nas conferências apresentadas a seguir somado a conferência Que é isso - a filosofia? (1955) seria, segundo Stein, "a questão do ser no horizonte da diferença ontológica." ${ }^{300}$ As conferências sobre as quais nos debruçaremos mais são: Identidade e diferença que contém uma conferência de 1957 O princípio de identidade e uma análise reelaborada do

\footnotetext{
${ }^{299}$ Heidegger, Seminários de Zollikon, 2001, p.236

${ }^{300}$ Stein, E. Nota do tradutor. In. Conferências e escritos filosóficos, 1973, p.208
} 
seminário de inverno de 1957 intitulada A constituição Onto-teo-lógica da Metafísica. Estes textos, ainda segundo Stein ${ }^{301}$, seriam em um segundo momento, iluminados quando compreendidos a partir da analítica existencial. É importante acentuarmos que apesar de Ser e tempo ter sido publicado em 1927, no que alguns consideram como uma primeira fase de Heidegger, ele é, todavia, retomado em muitas obras trazidas nesta pesquisa e mesmo em diversas obras tardias e também considerado como ponto de referência, por ser uma obra capital do autor, por muitos comentadores. A analítica existencial e a abertura do Dasein como ente privilegiado que existe e compreende ser continuará sendo um ponto chave de nossa pesquisa com relação ao que se compreende por humano em Heidegger $^{302}$. O que está em jogo nas obras tardias, mais propriamente a partir dos anos trinta ${ }^{303}$, está relacionado ao modo como o autor encara e acena para uma transformação de mundo não mais dependente apenas da singularização do Dasein. Em Ser e tempo o mundo em si mesmo não experimentaria uma inconsistência, não revelando, assim, nenhuma tendência para a transformação, apenas o Dasein inseriria uma instabilidade devido a sua incompletude ontológica $^{304}$. A mudança no pensamento de Heidegger acerca desta transformação e do deslocamento no pensamento do autor é muito bem descrita por Casanova na passagem a seguir.

Se em Ser e Tempo Heidegger buscava pensar por um lado o Dasein humano como um ente central no projeto de uma ontologia fundamental, em virtude de seu caráter privilegiado em termos ônticos e ontológicos [diferença ontológica], isto é, em virtude do fato de os seus modos de ser sempre implicarem uma relação com o

301 Stein, E. Nota do tradutor. In. Conferências e escritos filosóficos, 1973, p.207
${ }^{302}$ Veja Heidegger em Introdução a metafísica (1999), texto de 1935 , “a compreensão de ser,
embora indeterminada, possui para a nossa existência a suprema eminência, porquanto aí vai e se
afirma o poder, no qual se funda simplesmente a possibilidade essencial de nossa existência. [...]
Essa compreensão de ser e, mais ainda, o Ser mesmo constitui, portanto o que há de mais digno de
ser posto em questão (das Fragwürdigste) em tôda a investigação. A autenticidade de nossa
investigação se mede assim, quanto mais imediata e diretamente nos mantivermos fiéis ao que é
mais digno de ser investigado, a saber, o fato de que o Ser é para nós a compreensão (das
Verstandene) inteiramente indeterminada e, ao mesmo tempo, sumamente determinada. [...] Ora,
que compreendemos o Ser, não é apenas real mas também necessário. Sem essa abertura do ser
não poderíamos, de forma alguma, ser "homens". [...] Se, porém, o homem está na existência, é
uma condição necessária que ele possa estar presente ao Ser (da-sein), i.é que ele compreenda o
Ser. Enquanto isso for necessário o homem será também Historicamente real. [...] A
determinação, em que lhe compreendemos o significado indeterminado, pode-se, ao contrário,
delimitar univocamente (eindeutig), e não só, como algo acessório, mas, como a determinação,
que, sem o sabermos, nos domina desde o fundamento de nosso ser." (pp.110-112)
303 Casanova, M. Pensamento em transição: Heidegger e o outro início da filosofia In.
Fenomenologia hoje IV: fenomenologia, ciência e técnica, 2013 p.272
304 Casanova, M. Pensamento em transição: Heidegger e o outro início da filosofia In. Fenomenologia hoje IV: fenomenologia, ciência e técnica, 2013. p.288-289. 
ser e envolverem da mesma forma originariamente uma compreensão do ser do ente e do sentido de ser que sustenta os campos ônticos, a "viragem" consiste [obras tardias], por outro lado, propriamente na tentativa de pensar diretamente o $D a$ [o mundo], ao invés de descrever as transformações das ontologias históricas com base nas crises singularizantes [do ser-resoluto] do Dasein - esse parece ser o verdadeiro sentido da "hermenêutica da facticidade". ${ }^{305}$

Nossa tentativa em nos aproximarmos do que o autor alemão compreende por este deslocamento da transformação do Dasein para o $D a$, a partir da chamada viragem acarretará uma mudança de posição do próprio humano nas obras heideggerianas ele passa assim a ter como papel ser pastor e guardião do ser, da clareira do ser. Junto deste deslocamento, a diferença ontológica também passa a ser pensada não mais apenas no Dasein, mas acena para o próprio ser, para a própria retração do ser. Os caracteres existenciais, bem como sua unidade como cuidado não seriam negligenciadas, mas tomariam outro lugar na obra de Heidegger, apontando para outra postura do Dasein. Não é que o Dasein não pode mais se apropriar de si mesmo como ente resoluto antecipador, a questão é que esta singularização não garante a transformação do mundo. O que está em jogo agora é a possibilidade de acolhimento desta transformação como guardião do ser.

A diferença ontológica é [...] o modo a partir do qual a totalidade do ser se dá e o seu caráter mostra imediatamente uma facticidade inexorável. Se um Dasein, no sentido de ser um ente que participa do acontecimento do ser, implica se encontrar sempre já em meio à diferença ontológica. ${ }^{306}$

O autor no texto A Constituição Onto-teo-lógica da Metafísica ${ }^{307}$, busca pensar o que teria sido impensado (a diferença) a partir do que ele chama de o passo de volta (Rück-gang). Só realizando este passo do pensar ${ }^{308}$ poderemos estabelecer um diálogo com o todo da história da filosofia ${ }^{309}$, com a história do

\footnotetext{
305 Casanova, M. Pensamento em transição: Heidegger e o outro início da filosofia In. Fenomenologia hoje IV: fenomenologia, ciência e técnica, 2013. p.272-273

306 Casanova, M. Pensamento em transição: Heidegger e o outro início da filosofia In. Fenomenologia hoje IV: fenomenologia, ciência e técnica, 2013. p.284

${ }^{307}$ Este texto possui um diálogo com Hegel, uma vez que este autor seria para Heidegger a consumação do pensamento metafísico de esquecimento da diferença, junto à Nietzsche e também pelo fato de estar relacionado ao encerramento dos seminários de inverno sobre a ciência da lógica de Hegel. Esta pesquisa, entretanto, não vai abordar este diálogo, visto que o importante é entendermos o que Heidegger compreende por diferença após os anos 50 e sua relação com o que compreende por homem.

308 Talvez possamos compreender este pensar, este movimento do pensamento, como um movimento que pensa a essencialização do ser. Como a consumação da relação do ser com a essência do homem. Veja Sobre o humanismo,1973, p.347.

${ }^{309}$ A relação da diferença com a filosofia é trabalhada na conferência Que é isto - a filosofia? A filosofia, a identidade e a diferença estariam imbricadas numa relação circular, segundo Stein, na medida em que "não há filosofia sem as questões de identidade e diferença ontológicas; mas também não se levantam estas questões sem a filosofia." Ainda Stein, "o ser somente é ser porque
} 
pensamento e com a essência da verdade, tornando-a digna de ser pensada ${ }^{310}$. Esta ousada experiência ${ }^{311}$ do passo (palavras do autor) conduz para fora do que foi pensado na filosofia, recua diante do ser, vai do impensado (diferença enquanto tal) ao que deve ser pensado (esquecimento da diferença - velamento da diferença $)^{312}$. Seria uma interpretação falsa tomar o passo de volta como um passo isolado do pensamento ou como um retorno aos primeiros pensadores. O que está em jogo nele diz respeito ao próprio movimento do pensamento, dialogando com a totalidade essencial do pensamento ocidental, se movimentando para dentro da metafísica e para fora dela.

Para Heidegger [...] a metafísica se afastou deste começo [da filosofia], esquecendo a questão da diferença, dando em consequência, uma resposta equívoca à questão da identidade. Retornar a estas questões pelo passo de volta é revolver o solo em que mergulham as raízes da metafísica ocidental. ${ }^{313}$

Para isso, temos que ter em mente que o objeto (Sache) do pensamento é o ser e que a metafísica é onto-teológica, nesse sentido Heidegger nos descreve:

$\mathrm{Na}$ aula inaugural, "Que é metafísica?" (1929), a metafísica é, por isso, determinada como a questão do ente enquanto tal $e$ no todo. A omnitude deste todo é a unidade do ente que unifica enquanto fundamento pro-dutor. Para aquele que sabe ler, isto significa: A metafísica é onto-teo-logia. ${ }^{314}$

Após vinte anos, em 1949 o autor retoma o texto Que é metafísica? e elabora uma introdução, nela ele nos esclarece:

A metafísica, porém, representa a entidade do ente de duas maneiras: de um lado a totalidade do ente enquanto tal, no sentido dos traços mais gerais (òn kathólou, koinón); de outro, porém, e ao mesmo tempo, a totalidade do ente enquanto tal, no sentido do ente supremo e por isso divino (òn kathólou, akrótaton, theion). [...] Pelo fato de representar o ente enquanto ente é a metafísica em si a unidade destas duas concepções da verdade do ente, no sentido do geral e do supremo. De acordo com sua essência ela é, simultaneamente, ontologia no sentido mais restrito e teologia. A essência ontoteológica da filosofia propriamente dita (próte

é em si mesmo identidade e diferença; a tarefa da filosofia é questionar o ser nesta dimensão, porque dela brota sua própria possibilidade." Ambas as passagens em Stein, E. Nota do tradutor. In. Conferências e escritos filosóficos, 1973, p.209. Não vamos adentrar a fundo o texto Que é isto - a filosofia, mas vamos tangenciá-lo constantemente por se tratar de uma conferência da década de 50 e cuja temática, Stein concordaria, trataria da questão do ser no horizonte da diferença ontológica.

${ }^{310}$ Heidegger, A constituição Onto-teo-lógica da Metafísica In. Identidade e diferença, 1973, p.390.

${ }^{311}$ Heidegger, A constituição Onto-teo-lógica da Metafísica In. Identidade e diferença, 1973, p.390.

${ }^{312}$ Heidegger, A constituição Onto-teo-lógica da Metafísica In. Identidade e diferença, 1973, p.391

${ }^{313}$ Stein, E. Nota do tradutor. In. Conferências e escritos filosóficos, 1973, p.209

${ }^{314}$ Heidegger, A constituição Onto-teo-lógica da Metafísica In. Identidade e diferença, 1973, p.392. Num diálogo com Hegel e Fichte ele nos apresenta tal conclusão. 
philosophía) deve estar, sem dúvida, fundada no modo como lhe chega ao aberto o ón, a saber, enquanto ón. ${ }^{315}$

Segundo Casanova ${ }^{316}$, Heidegger teria visto que a metafísica indaga o ser do ente enquanto ente [já visto e apontado em Ser e tempo] e por isso seria ontologia. O que Heidegger faz é justamente indagar o ser como tal [pergunta fundamental]. A maneira de colocar a questão traria a diferença entre a ontologia metafísica e a ontologia heideggeriana. A metafísica compreende o ser do ente como ente partindo de uma pre-compreensão das essências, e o ente acaba sendo determinado como estabilidade e presença, desconsiderando por completo a finitude do ser e do Dasein humano. Pressupor a presença seria algo infundado, uma vez que o ser não seria presencial e não poderia assim se fundar como presença constante. A presença seria, assim, uma tentativa de esquecimento da diferença ontológica. O que passa a estar em jogo são as presentificações do ser, o modo como a presença se presentifica. Para Dastur, haveria dois momentos, dois textos de Heidegger, em que

um [...] Heidegger se demora ao interior da metafísica, mostraria como a presença temporal dos entes viria de um pensamento mais original, aquele do ser ele mesmo como presença (Anwesenheit), e um outro pelo qual a determinação de ser como presença se tornaria ela mesma problemática e definiria em tanto que tal o limite do modo ocidental do pensamento, abrindo assim a possibilidade de pensar o ser segundo uma outra dimensão que aquela da presença, como retiro ou ausência. ${ }^{317}$

A questão que surge para Heidegger da tomada da metafísica como ontoteológica é como se originaria tal constituição (a essência desta constituição)? Como a filosofia [ontológica] em seu livre engajar-se no ente exige e determina como Deus entra nela? Assumir a pergunta pela origem da constituição ontoteológica da metafísica é justamente realizar o passo de volta ${ }^{318}$.

A partir de um diálogo com o todo da história da filosofia e com Hegel, no horizonte de seu olhar ${ }^{319}$, Heidegger tenta se aproximar de tais respostas. Assim, ele nos descreve como o pensamento - como "lógica" pensado a partir das "logias" (onto-logia, teo-logia, psico-logia...) - "explora e funda o ente enquanto

\footnotetext{
${ }^{315}$ Heidegger, Que é metafísica? [introdução], 1949/1973, p.259

316 Casanova, M. Pensamento em transição: Heidegger e o outro início da filosofia In. Fenomenologia hoje IV: fenomenologia, ciência e técnica, 2013. p.281-283

${ }^{317}$ Dastur, Heidegger, Derrida et la question de la différence, In. Derrida, la tradition de la philosophie, 2008, p.89.

${ }^{318}$ Heidegger, A constituição Onto-teo-lógica da Metafísica In. Identidade e diferença, 1973, p. 393

${ }_{319}$ Heidegger, A constituição Onto-teo-lógica da Metafísica In. Identidade e diferença, 1973, p.393
} 
tal e no todo a partir do ser como fundamento (lógos)." ${ }^{320}$ O Ser "desde a aurora de seu desocultamento, interpela, através de seu caráter de lógos ${ }^{321}$, de fundamento fundante, o pensamento e lhe impõe a tarefa de fundamentar." ${ }^{322}$ Ele se manifestando como pensamento, se desoculta como o fundamento que a si mesmo explora e funda. Ser pensado aqui como fundamento fundante através de seu caráter de logos impõe ao pensamento a tarefa de fundamentar no todo. Isso significa explorar o ente enquanto tal e o fundar no seu todo. Como vimos o ser é objeto do pensamento, nesse sentido, ele, segundo a natureza do fundamento, só poderia ser radicalmente pensado quando o fundamento fosse representado como o primeiro fundamento, como causa sui. Designamos assim, o conceito metafísico de Deus. A metafísica em direção a este último e primeiro fundamento deveria ultrapassar tudo em direção de Deus. Apesar deste esclarecimento parecer tocar algo certo, para o autor seria ainda insuficiente para pensar a essência da metafísica, pois ela deve ser pensada a partir da unidade teológica-ontológica. E não partindo apenas de uma delas. Sobre esta unidade onto-teo-lógica, Carneiro Leão nos descreve:

A essencialização do pensamento ocidental, em que a existência do ocidente toma consciência de si mesma, é absorventemente lógica no sentido de edificada na interdependência de fundamento e fundado. E por ser lógica é de modo igual ôntica e teísta. É igualmente ôntica, porque o ser é o fundamento do ente "on". É igualmente teísta, porque, por necessidade da própria fundamentação, o ente só será realmente fundamentado, se se fundar num último fundamento, que exclua a possibilidade e necessidade de ulterior fundamentação. Esse fundamento supremo é absoluto, o theos. Assim, tendo principiado com o esquecimento do Ser, a história da metafísica desdobra em todos os períodos de seu desenvolvimento numa multiplicidade de formas essa constituição onto-teo-léogica. ${ }^{323}$

Heidegger então, nos questiona: como surgiria, então, o comum-pertencer da ontologia e da teologia? Até agora foi impensada a origem desta unidade, da diferença do diferente que as unifica. Tal unidade não ocorreria de modo a que cada uma teria sua independência em relação à outra, ou seja, elas não seriam autônomas. Elas se co-fundamentam e estão assentadas na impensada diferença.

\footnotetext{
${ }^{320}$ Heidegger, A constituição Onto-teo-lógica da Metafísica In. Identidade e diferença, 1973, p.394

${ }_{321}$ Para a relação Logos - ser - aurora do desocultamento [grego] Veja Heidegger, Introdução à metafísica, capítulo IV: A delimitação do ser, (1999). Veja também Que é isto - a filosofia? (1955/1973) - "aos gregos se manifesta a essência da linguagem como lógos." p.221

${ }^{322}$ Heidegger, A constituição Onto-teo-lógica da Metafísica In. Identidade e diferença, 1973, p.393

${ }^{323}$ Carneiro Leão, Itinerário do pensamento de Heidegger In. Introdução à metafísica, 1999, p.17
} 
"Na unidade do ente enquanto tal em geral e supremo repousa a constituição da essência da metafísica.",324

Para conseguirmos nos aproximar da essência da metafísica, de sua unidade constitutiva onto-teológica e do pensamento ocidental, para então pensarmos o lugar do dito humano nesta essencialização da metafísica e sua relação com a diferença ontológica, Heidegger discorre sobre o ser como aquele que não pode ser pensado senão na sua diferença com o ente, e o ente em sua diferença com o ser. Ser é sempre ser de um ente e ente é ente do ser. Ente e ser só podem ser encontrados no seio desta diferença. Tanto ser quanto ente seriam encontrados a partir da diferença ${ }^{325}$. A diferença se torna então objeto de sua análise ${ }^{326}$ e pode ser confrontada a partir do passo de volta, pois assim liberaria seu objeto do pensamento, o ser da diferença. Podemos então afirmar que, segundo o autor, o ser e o ente não se "fundem", mas mantem-se separados num entre em que sua unidade ser e ente é conservada. Ser é o que sobrevém desocultando (desvelando) e ente se mostra como advento que se oculta no presente. A diferença de algum modo separa e mantém, conservando sua unidade e a possibilidade de acontecerem (ente e ser) como fenômenos. A diferença é decisão (Austrag) onde impera o desocultamento e ocultamento de ambos - ser e ente - sobrevento e advento, separando-os e unindo-os em constituições específicas ao longo da História do ser.

O ser é o sobrevento que desoculta o ente e assim desvela aquilo que oculta: o advento do ente. Chega-se então a uma solução, que logo se torna dis-solução; por isso traduzo Austrag por de-cisão, que significa a insuprimível diferença entre ser e ente. Por causa disso a identidade heideggeriana é dinâmica. ${ }^{327}$

O interessante é que neste ponto do seminário Heidegger nos faz compreender melhor a história do pensamento ocidental, quando nos diz que o ser se dá com este ou aquele cunho Historial, ele se determina a partir do modo como se revela. Modo este, Historialmente destinado, também chamado de Epocal que "para nós somente acontece e impera se o liberamos para aquilo que, do que foi e

\footnotetext{
${ }^{324}$ Heidegger, A constituição Onto-teo-lógica da Metafísica In. Identidade e diferença, 1973, p.395.

${ }^{325}$ Heidegger, A constituição Onto-teo-lógica da Metafísica In. Identidade e diferença, 1973, p.395-396.

${ }^{326}$ Heidegger, A constituição Onto-teo-lógica da Metafísica In. Identidade e diferença, 1973, p. 395

${ }^{327}$ Stein, E. Nota do tradutor [Nota 6]. In. Conferências e escritos filosóficos, 1973, p.396
} 
continua sendo, lhe é próprio" ${ }^{328}$. A proximidade com este cunho Epocal se daria por uma lembrança, "para a experiência de cada cunho da diferença do ser do ente ao qual corresponde uma interpretação do ente enquanto tal"329, como physis, lógos, hén, idéa, enérgeia, substancialidade, objetividade, subjetividade, vontade, vontade de poder, vontade de vontade ${ }^{330}$. E assim ele nos aponta a possibilidade de pensarmos algo comum, talvez uma unidade que perpassasse os destinos Historiais do ser. Nas palavras dele: “Talvez se manifeste mesmo pela discussão da diferença de ser e ente, na de-cisão [na diferença], algo comum, que perpassa o destino do ser desde o começo até sua plenitude" ${ }^{\text {331 }}$. Heidegger reconhece a dificuldade de se pensar esta generalidade, se é que podemos chamá-la assim. Mas nos aponta a possibilidade de se pensar uma história do pensamento que seria História do ser e da essência da metafísica enquanto esta dação de ser manifestada em interpretações do ente enquanto tal. Manifestadas pela discussão da diferença entre ser e ente na decisão, como ultrapassagem - sobrevento (transcendência) do ser e advento (presentar) do ente ${ }^{332}$. Assim, Heidegger nos pergunta, como pensar a diferença como decisão? Em que medida a constituição onto-teo-lógica da metafísica tem sua origem essencial na decisão que inicia a história da metafísica e perpassa suas épocas ${ }^{333}$ ? A decisão é deste modo, essência da diferença e origem da história da metafísica ${ }^{334}$, perpassando suas épocas, mas se mantendo velada como decisão, esquecida. Heidegger nos adverte que este esquecimento (da decisão) subtraído faz parte da diferença e vice-versa ${ }^{335}$.

Pensando o ser a partir do fenômeno no qual ele se revela como lógos, Heidegger tenta esclarecer ao leitor, esta relação que é unida e separada entre ser e

\footnotetext{
${ }^{328}$ Heidegger, A constituição Onto-teo-lógica da Metafísica In. Identidade e diferença, 1973, p.397

${ }^{329}$ Heidegger, A constituição Onto-teo-lógica da Metafísica In. Identidade e diferença, 1973, p.397

${ }^{330}$ Heidegger, A constituição Onto-teo-lógica da Metafísica In. Identidade e diferença, 1973, p.397

${ }^{331}$ Heidegger, A constituição Onto-teo-lógica da Metafísica In. Identidade e diferença,1973, p.397. (Grifado nosso).

${ }^{332}$ Heidegger, A constituição Onto-teo-lógica da Metafísica In. Identidade e diferença, 1973, p.397

${ }^{333}$ Heidegger, A constituição Onto-teo-lógica da Metafísica In. Identidade e diferença, 1973, p.397

${ }^{334}$ Heidegger, A constituição Onto-teo-lógica da Metafísica In. Identidade e diferença, 1973, p. 397

${ }^{335}$ Heidegger, A constituição Onto-teo-lógica da Metafísica In. Identidade e diferença, 1973, p.391
} 
ente. Como um circular, a decisão é ente e ser, um em torno do outro ${ }^{336}$. A decisão é circular. Isso fica claro quando vemos que o ser como lógos é o fundamento, ser como fundante e o ente como fundado que fundamenta o ser, por isso a circularidade. Logos que funda no geral e no supremo, no universal e no único: onto - teo - lógica. A Metafísica corresponde ao ser do lógos ${ }^{337}$, a lógica é determinada pelo diferente da diferença, pela união: onto-teo-lógica. Ela, a metafísica, se volta para o ente no todo e com isso para o diferente da diferença, a união do geral e do supremo ${ }^{338}$, onto - teo. O que acontece é que não se leva em consideração a diferença como diferença, que permanece esquecida, não lembrada. O pensamento da metafísica é a partir da decisão que une e separa e permanece engajado na diferença como tal impensada ${ }^{339}$. "Durante todo o decurso da história do Ocidente a diferença constitui sempre o fundamento esquecido e não pensado de todo o pensamento metafísico." 340 A decisão consuma a diferença entre ser e ente (separados e unidos) como onto-teológica, nos trazendo como destinos deste ocultamento da decisão ${ }^{341}$ interpretações distintas do ser do ente.

Esta breve análise, segundo o autor, mostra um caminho possível para respondermos à questão como Deus entra na filosofia? Ele entra a partir da própria essência da metafísica, pela decisão - “insuprimível di-ferença entre ser e ente." ${ }^{342}$ Ela, a decisão, é essência da própria diferença sustentada e consumada $^{343}$. Ela (a diferença - entre ser e ente) constitui o traçado básico no edifício da metafísica ${ }^{344}$. A decisão dá como resultado ser como fundamento que necessita de fundamentação, causa sui. Nome adequado para Deus na filosofia.

Este seria o passo de volta, para dentro e para fora da essência da metafísica, para fora do esquecimento da diferença e para dentro do destino do ocultamento

\footnotetext{
${ }^{336}$ Heidegger, A constituição Onto-teo-lógica da Metafísica In. Identidade e diferença, 1973, p. 398

${ }^{337}$ Heidegger, A constituição Onto-teo-lógica da Metafísica In. Identidade e diferença, 1973, p.398

${ }^{338}$ Heidegger, A constituição Onto-teo-lógica da Metafísica In. Identidade e diferença, 1973, p.398

${ }^{339}$ Heidegger, A constituição Onto-teo-lógica da Metafísica In. Identidade e diferença, 1973, p.399

${ }^{340}$ Carneiro Leão, Itinerário do pensamento de Heidegger In. Introdução à metafísica, 1999, p.13

${ }^{341}$ Heidegger, A constituição Onto-teo-lógica da Metafísica In. Identidade e diferença, 1973, p.398

${ }^{342}$ Ernildo stein In. Heidegger, A constituição Onto-teo-lógica da Metafísica In. Identidade e diferença, 1973, p.396 [nota 6 de pé de página]

${ }^{343}$ Heidegger, A constituição Onto-teo-lógica da Metafísica In. Identidade e diferença, 1973, p.399

${ }^{344}$ Heidegger, A constituição Onto-teo-lógica da Metafísica In. Identidade e diferença, 1973, p.399
} 
da decisão, ocultamento que se subtrai, que não se deixa revelar. Este passo do pensamento pode tornar-se autêntico, não sabemos como, nem quando, nem onde. Esta autenticidade pode abrir novos caminhos e aponta, segundo Heidegger, para a compreensão do acontecimento apropriação ${ }^{345}$.

Surge neste momento um problema apontado por Heidegger, as palavrasguias da metafísica como ser e ente, fundamento-fundado nascem como o diferente da diferença - a união. "A origem da diferença não mais se deixa pensar no horizonte da metafísica." ${ }^{346}$ Nossa dificuldade estaria, assim, na linguagem. Nossas linguagens (ocidentais) são línguas metafísicas. $\mathrm{O}$ "é" conteria todo o destino do $\operatorname{ser}^{347}$. Desse modo, ele nos questiona, seria possível pensar outro modo de dizer? Um não dizer que diz? Esperando que, talvez, a semente deste seminário "possa à sua maneira, pouco importa quando, nascer e frutificar."348

Nesta mesma compilação, Identidade e diferença, temos a conferência $O$ princípio de identidade (1957) no qual Heidegger nos esclarece o acontecimento apropriação. Como ele nos descreve que o passo do pensamento (o passo de volta) se tornaria autêntico a partir do acontecimento apropriação, o autor nos obriga, assim, a buscarmos uma claridade do termo. Não vamos nos aprofundar em todas as minúcias que este texto pode suscitar, mas vamos tentar esclarecer o que Heidegger teria compreendido pelo acontecimento apropriação e assim pensarmos sua relação com a diferença aqui abordada e o papel do humano nesta imbricação. Fica claro o deslocamento do ser resoluto como transformador de mundo para a necessidade de compreensão do acontecimento apropriação para esclarecermos nas obras tardias como Heidegger apresentou a transformação de mundo. Segundo Casanova,

a analítica existencial sobrecarrega de fato, o Dasein, com um peso que conceitualmente ele jamais seria capaz de suportar. Quase como um Atlas que leva o mundo sobre as costas, o Dasein se torna em Ser e tempo o ponto arquimediano da transformação de mundo, algo pelo que é compelido a responsabilizar-se. A atribuição de uma carga excessiva consignada ao Dasein impõe, desta maneira, a

\footnotetext{
${ }^{345}$ Heidegger, A constituição Onto-teo-lógica da Metafísica In. Identidade e diferença, 1973, p.399

${ }^{346}$ Heidegger, A constituição Onto-teo-lógica da Metafísica In. Identidade e diferença, 1973, p.399 (Grifado nosso)

${ }^{347}$ Heidegger, A constituição Onto-teo-lógica da Metafísica In. Identidade e diferença, 1973, p. 400 .

${ }^{348}$ Heidegger, A constituição Onto-teo-lógica da Metafísica In. Identidade e diferença, 1973, p.400
} 
Heidegger uma revisão, que se realiza completamente na direção da noção de "acontecimento apropriador". ${ }^{349}$

Seu texto inicia-se pelo questionamento do que seria o princípio da identidade, título da conferência. Ordinariamente o tomamos a partir da fórmula $\mathrm{A}=\mathrm{A}$, mas não poderíamos pensar numa tautologia como planta é planta, planta $=$ planta. O que está em jogo neste princípio seria a devolução de cada coisa a si mesmo. "Cada coisa ela mesma é a si mesma devolvida [...] em cada identidade reside a relação 'com', portanto uma mediação [...] a união na unidade." ${ }^{350}$ Tal princípio ainda não responderia pela identidade, uma vez que pressupõe o seu significado. Na fórmula A é A o "é" falaria do ser do ente, em cada ente uma identidade, uma unidade consigo mesmo ${ }^{351}$. Em toda parte do pensamento ocidental-europeu somos interpelados pela identidade como unidade, o que garantiria os fenômenos e a própria ciência. "O princípio da identidade fala do ser do ente." 352

O ser do ente, segundo Heidegger, teria chegado primeiro em Parmênides, numa de suas proposições: “o mesmo, pois tanto é apreender (pensar) como também ser." ${ }^{353}$ Ser e pensar seriam nesta sentença coisas diferentes, mas pensadas como o mesmo, como uma unidade. E que o autor alemão teria interpretado como um comum-pertencer (Zusammengehörigkeit) em que ser e pensar estão. Imbrincados numa reciprocidade pertencem e fazem parte de uma identidade, de um mesmo. Heidegger deu ênfase ao pertencer do - comumpertencer - em que a comunidade, o comum, a unidade é experimentada a partir do pertencimento e não o contrário.

Compreendendo o pensar como uma característica do homem Heidegger aponta uma reflexão possível sobre um comum-pertencer que se refere a homem e Ser. O homem é um ente e, dessa forma, faz parte da totalidade do $\mathrm{Ser}^{354}$, está inserido no ser e como privilegiado é o único que se relaciona com o Ser, está aberto, como pensante, para o Ser. Ele corresponde ao Ser e esta

\footnotetext{
349 Casanova, M. Pensamento em transição: Heidegger e o outro início da filosofia In. Fenomenologia hoje IV: fenomenologia, ciência e técnica, 2013. p.275-276.

${ }^{350}$ Heidegger, O princípio da identidade In. Identidade e diferença, 1973, p.377 (Grifado nosso)

${ }^{351}$ Heidegger, O princípio da identidade In. Identidade e diferença, 1973, p.378

${ }^{352}$ Heidegger, O princípio da identidade In. Identidade e diferença, 1973, p.378

${ }^{353}$ Heidegger, O princípio da identidade In. Identidade e diferença, 1973, p.378

${ }^{354}$ Heidegger, O princípio da identidade In. Identidade e diferença, 1973, p.380
} 
correspondência é o homem ${ }^{355}$. O ser se presenta, em sentido primordial, ao homem ${ }^{356}$, ele é quando aborda o homem pelo apelo, pois só o homem propicialhe o advento [do ente] como presentar ${ }^{357}$. Há um pertencer recíproco a partir do qual homem e ser recebem as determinações de sua essência, que foram compreendidas pela filosofia. "Heidegger coloca então o acento sobre o retiro do ser e se dirige até um pensamento do Ereignis, do acontecimento apropriando o homem e o ser." 358 Neste sentido, Stein nos descreve que "em $O$ princípio de identidade, esta questão [questão do Ser no horizonte da diferença ontológica] é o ponto de partida para uma análise da relação entre Ser e homem."

Como penetrarmos, então, no comum-pertencer: Pensar (Homem) - ser? A resposta de Heidegger vai em direção a uma não mediação, uma vez que a mediação, como vimos, já faria parte de um comum-pertencer, de uma unidade, de uma relação com, de uma identidade. Dessa forma, a não mediação se daria por um salto que se distancia do pensamento que representa, que fundamenta. Um salto no abismo (sem fundamento). Este salto não mediado salta no pertencer, dispensando a reciprocidade homem e ser e instaurando a constelação de ambos. Nela que ambos atingem suas essências, "entregues como propriedade a partir de um gesto que dá ${ }^{360}$, dispondo e harmonizando a experiência do pensar.

Em que constelação estaríamos? O autor nos questiona. Estaríamos no que Heidegger chama de essência da técnica ${ }^{361}$, o autor não pensa a técnica apenas como um negócio do homem, mas como um destino ontológico-historial. O apelo

\footnotetext{
${ }^{355}$ Heidegger, O princípio da identidade In. Identidade e diferença, 1973, p.380

${ }^{356}$ Mais à frente desta pesquisa veremos que o homem é propriedade ao Ser e o Ser apropriado ao homem. De forma que, o Ser se presenta ao homem e ao homem se presenta o ser. "Se, porém, o homem está na existência, é uma condição necessária que ele possa estar presente ao Ser (da-sein), i.é que ele compreenda o Ser.” Heidegger, Introdução à metafísica, 1999, p.111.

${ }^{357}$ Heidegger, O princípio da identidade In. Identidade e diferença, 1973, p.380

${ }^{358}$ Dastur, Heidegger, Derrida et la question de la différence, In. Derrida, la tradition de la philosophie, 2008, p.101

${ }^{359}$ Stein, E. Nota do tradutor. In. Conferências e escritos filosóficos, 1973, p.208

${ }^{360}$ Heidegger, O princípio da identidade In. Identidade e diferença, 1973, p.381

361 “A técnica é em sua essência, um destino ontológico-historial da verdade do ser, que reside no esquecimento. A técnica não remonta, na verdade, apenas com seu nome até a tékhne dos gregos, mas ela se origina ontológico-historialmente da tékhne como um modo do aletheúein, isto é, do tornar manifesto o ente. Enquanto uma forma da verdade, a técnica se funda na história da Metafísica. Esta é uma forma privilegiada da história do ser e a única na qual, até agora, podemos ter uma visão do conjunto." (Heidegger, Sobre o humanismo, 1973, p.361) Esta passagem busca apenas apresentar brevemente a relação da técnica como um destino historial no qual o homem participa. Não vamos nos aprofundar no modo como ela aconteceu, nem os motivos pelos quais Heidegger a considera privilegiada. Para compreensão da essência da técnica veja também Heidegger, Serenidade, 1955/2001 e Heidegger, A questão da técnica 1953/2007.
} 
do ser (como destino do ser) fala na essência da técnica ${ }^{362}$. Nela tanto o ser quanto o homem pertencem, são provocados (pela Gestell - arrazoamento), chamados à razão para "armazenar o ente que aborda como o fundo de reserva para seu planificar e calcular e a realizar esta exploração indefinidamente." ${ }^{363}$ Neste processo de provocação - arrazoamento - ouvimos o confronto de homem e ser e a interpelação que determina a constelação de nossa época. "O arrazoamento nos agride diretamente em toda a parte." ${ }^{364}$ Sobre este apelo do ser Carneiro Leão nos descreve que o apelo e o destino do ser

são o fundamento em que se essencializa a diferença irredutível e a referência necessária entre o ente e seu ser. Provém da iluminação dessa identidade e diferença e se dirigem ao homem em cuja existência se instaura a diferença referente [ente e ser]. Ora, de vez que a palavra grega, logos, significa o fundamento em virtude do qual alguma coisa pode ser colhida e recolhida como isso ou aquilo, Heidegger chama a diferença referente, em cujo fundamento o ente se essencializa em seu ser, de diferença ontológica. ${ }^{365}$

Haveria então, um comum-pertencer do homem e do ser, sob a forma de uma constelação chamada técnica que determina nossa época e nos agride em toda a parte. Só podemos penetrar nela a partir de uma não mediação, de um salto no abismo sem fundamento, no pertencimento desta constelação. O comumpertencer homem e ser fala de como o homem é propriedade ao ser e o ser apropriado ao homem. Esta experiência de apropriação de um e outro é o que Heidegger chama de acontecimento-apropriação. A partir de um jogo de palavras entre Er-eignen (acontecer) e Er-äugnen (descobrir com o olhar apropriar). Segundo Casanova, o acontecimento apropriador seria "o lugar onde se constitui a experiência sempre e a cada vez histórica do ver o ente enquanto ente." ${ }^{366}$ Casanova nos chama a atenção para o acento sobre a raiz Eigen (próprio) em relação com Ereignis, que teria permanecido em Ser e tempo e em seus escritos posteriores ${ }^{367}$. O próprio (Eigen) aqui, não seria mais como em Ser e tempo uma reconquista de uma relação autêntica com seu poder-ser, superando a impessoalidade dos sentidos e significados fornecidos pelo mundo. Mas o próprio

\footnotetext{
${ }^{362}$ Heidegger, O princípio da identidade In. Identidade e diferença, 1973, p.382

${ }^{363}$ Heidegger, O princípio da identidade In. Identidade e diferença, 1973, p.382

${ }^{364}$ Heidegger, O princípio da identidade In. Identidade e diferença, 1973, p.382. (Grifado é nosso)

${ }^{365}$ Carneiro Leão, Itinerário do pensamento de Heidegger In. Introdução à metafísica, 1999, p.13

366 Casanova, M. Pensamento em transição: Heidegger e o outro início da filosofia In. Fenomenologia hoje IV: fenomenologia, ciência e técnica, 2013. p.277 (Grifado nosso)

367 Casanova, M. Pensamento em transição: Heidegger e o outro início da filosofia In. Fenomenologia hoje IV: fenomenologia, ciência e técnica, 2013. p.277
} 
no acontecimento apropriador acontece quando o homem recebe o seu próprio a partir do acontecimento mesmo, deixando-se se apropriar por ele ${ }^{368}$. Ou seja, o próprio aconteceria quando o homem salta no pertencimento homem-ser, no acontecimento apropriação, recebendo dele o seu próprio. Este salto poderia ser pensado como o recebimento do próprio, em que ser e homem atingiriam suas essências. O que se esperaria como possibilidade hoje é a superação e aprofundamento do arrazoamento, da técnica, encontrando mais autenticamente o caminho para o acontecimento-apropriação. Onde ser e homem seriam pensados de modo essencial, atingiriam suas essências e conquistariam seu caráter historial, perdendo aquelas determinações que a metafísica lhes emprestou ${ }^{369}$.

No acontecimento-apropriação fala a possibilidade de ele poder superar e realizar em profundidade o simples imperar do arrazoamento num acontecer mais originário. Uma tal superação e aprofundamento do arrazoamento, partindo do acontecimento apropriação e nele penetrando, traria a redenção historial - portanto, jamais unicamente factível pelo homem - do universo técnico, de sua ditadura, para pô-lo a serviço no âmbito através do qual o homem encontra mais autenticamente o caminho para o acontecimento apropriação. ${ }^{370}$

Fica claro nesta passagem que uma possível superação da constelação que hoje nos encontramos, a técnica, e uma possível redenção historial não se dariam de forma alguma, apenas por meio de uma singularização do Dasein humano antecipador resoluto. Mas o que acontece agora para o homem é a possibilidade de penetrar neste pertencimento do acontecimento apropriação. Uma transformação possível não se daria por meio do homem, mas pelo próprio acontecer, é ele que poderia superar a ditadura técnica na qual nos encontramos, nos desapropriando dela e nos entregando ao que nos é mais próprio. Ao homem caberia a dócil participação, o suportar da clareira ${ }^{371}$, o manter-se aberto, saltando no acontecimento apropriação onde a linguagem fala como a casa do $\operatorname{ser}^{372}$. Como vimos, a linguagem é a casa do ser, onde o ser fala, uma vez que o pensar (do ser $)^{373}$ “deposita seu dizer do ser na linguagem como habitação da ec-sistência"374 do homem. Como habitante desta morada do ser (a linguagem), entregues "à

\footnotetext{
368 Casanova, M. Pensamento em transição: Heidegger e o outro início da filosofia In. Fenomenologia hoje IV: fenomenologia, ciência e técnica, 2013. p.278

${ }^{369}$ Heidegger, O princípio da identidade In. Identidade e diferença, 1973, p.383

${ }^{370}$ Heidegger, O princípio da identidade In. Identidade e diferença, 1973, p.383 (Grifado nosso)

${ }^{371}$ Heidegger, Seminários de Zollikon, 2001, p.293

${ }^{372}$ Heidegger, O princípio da identidade In. Identidade e diferença, 1973, p.384

${ }^{373}$ Heidegger, Sobre o humanismo, 1973, p.348

${ }^{374}$ Heidegger, Sobre o humanismo, 1973, p.371
} 
linguagem como propriedade, residimos no acontecimento apropriação.” ${ }^{\text {„375 Ao }}$ homem caberia, assim, pastorear, resguardar este espaço de morada, entregue ao ser, recebendo assim seu chamado, seu apelo para guardar a verdade do $\operatorname{ser}^{376}$ que é também resguardar a essência do humano ${ }^{377}$. Lembrando que ao dizer que o homem é pastor do ser, Heidegger nos diz que este pastorear diz respeito à experiência da existência como cuidado apontada em Ser e tempo ${ }^{378}$. Talvez, o cuidado antecipador resoluto é aquele que ouve o apelo do ser e resguarda sua morada. Só assim, talvez, o homem alcance o autêntico pertencimento e caminho do acontecimento apropriação. Vale acentuar que apesar do deslocamento de papel do Dasein humano, Heidegger parece manter a analítica do Dasein, o cuidado como unidade de ser deste ente e apropriação de si mesmo como abertura ao ser, como um ponto importante para pensarmos o homem.

O autêntico comum-pertencer como acontecimento apropriação é o que poderia resultar do passo de volta que descrevemos a pouco. Passo do pensamento em direção à diferença impensada, ao esquecimento da diferença, à decisão que mantém unidos e separados na irredutível diferença - ente e ser, advento e sobrevento. Sobre o Acontecimento apropriação, Heidegger nos descreve.

Supondo que nos aguarde a possibilidade de que o arrazoamento, recíproca provocação de homem e ser para o cálculo do que é calculável, nos convoque e se nos explicite como acontecimento apropriação que desapropria homem e ser entregando-os àquilo que lhes é próprio, então estaria livre o caminho em que o homem experimenta de maneira mais originária o ente, a totalidade do moderno universo da técnica, da natureza e da história e, antes de todos, o ser deles. ${ }^{379}$

É no acontecimento apropriação que podemos verificar a essência da identidade, não mais como tradicionalmente pensada a partir de um traço do $\operatorname{ser}^{380}$, como fundamento do ente, mas como identidade de ser e pensar que brota do comum-pertencer como acontecimento-apropriação. $\mathrm{O}$ autor alemão nos questiona, podemos nós penetrar na origem da identidade? A penetração exige um salto, o acontecimento apropriação da onde brota a essência da identidade entre

\footnotetext{
${ }_{375}^{375}$ Heidegger, O princípio da identidade In. Identidade e diferença, 1973, p.384

${ }^{376}$ Heidegger, Sobre o humanismo, 1973, p.361

${ }^{377}$ Heidegger, Sobre o humanismo 1973, p.367 e "Na medida em que nossa essência está entregue à linguagem como propriedade, residimos no acontecimento apropriação." Heidegger, O princípio da identidade In. Identidade e diferença, 1973, p.384

${ }^{378}$ Heidegger, Sobre o humanismo 1973, p.356

${ }^{379}$ Heidegger, O princípio da identidade In. Identidade e diferença, 1973, p.384

${ }^{380}$ Identidade pensada como estático traço do ser, em direção de um télos (fim), de uma síntese suprema (Hegel) ou em direção da arkhé (começo), do fundamento. (Stein, E. Nota do tradutor [Nota 2]. In. Conferências e escritos filosóficos, 1973, p.379
} 
ser e pensar, entre homem e ser, da identidade enquanto tal. Um salto para a origem da identidade. Ou seja, somente a partir do atingimento de nossa essência e da essência do ser poderíamos penetrar na origem da identidade. Este salto "é marcado por uma dinâmica repentina e abrupta, um movimento instantâneo de rearticulação da historicidade do ser, em uma palavra, um instante de decisão

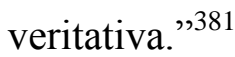

O abismo saltado, o sem fundamento, onde não mais se pensa o ser como fundamento do ente, é o próprio acontecimento apropriação, nele vibra a linguagem em que está nossa essência e a casa do ser. É neste salto no pertencimento homem-ser, homem-pensar, que o homem, como pastor do ser, pode encaminhar-se e ser convocado pelo acontecimento apropriação. Agora não mais, como em Ser e tempo, em que era no homem singular que havia a possibilidade de transformações históricas, agora, cabe à convocação do acontecimento apropriação esta possibilidade, na medida em que o homem pode experienciar-se como cuidado, como pastor do ser e sustentar este espaço para a convocação deste acontecimento. Segundo Dastur, depois da virada Heidegger tenta pensar "a diferença não mais achando sua origem na transcendência do Dasein, mas como uma dimensão pertencente ao ser mesmo, como esta dupla dobra do ser e do ente que os torna inseparáveis um e outro." ${ }^{\text {„32 }}$ Ela nos diz que Heidegger vai pensar o retiro do ser que advém ao mesmo tempo e com a aparição do ente, o ser mesmo é pensado como proveniente da diferença ${ }^{383}$. E não mais como presença daquilo que é presente, a entidade ${ }^{384}$.

O acontecimento apropriação, o atingimento das essências - homem e ser, a penetração neste comum-pertencer homem e ser marcaria o movimento de rearticulação da historicidade do ser e do próprio homem. A penetração neste autêntico acontecimento apropriação onde vibra a linguagem poderia assim, resguardar uma abertura às transformações da história do ser e do próprio homem. Uma nova vibração da linguagem do ser poderia acontecer. Então aos homens e, talvez, mais ainda àqueles que são os guardas da casa do ser, os pensadores e

381 Casanova, M. Pensamento em transição: Heidegger e o outro início da filosofia In. Fenomenologia hoje IV: fenomenologia, ciência e técnica, 2013. p.279

${ }^{382}$ Dastur, Heidegger, Derrida et la question de la différence, In. Derrida, la tradition de la philosophie, 2008, p.102

${ }^{383}$ Dastur, Heidegger, Derrida et la question de la différence, In. Derrida, la tradition de la philosophie, 2008, p.103

${ }^{384}$ Dastur, Heidegger, Derrida et la question de la différence, In. Derrida, la tradition de la philosophie, 2008, p.101 
poetas $^{385}$ esperam, resguardam um outro dizer, talvez, um dizer que não diz. A partir daí Heidegger nos questiona:

Podemos nós então pensar que a penetração na origem essencial da identidade pelo pensamento [pelo passo de volta - passo do pensar] se deixa realizar num dia? Precisamente pelo fato de esta penetração exigir um salto, ela precisa de seu tempo, o tempo do pensamento, que é bem outro do que aquele do cálculo [característico da essência da técnica - constelação - época na qual nos encontramos] que hoje em dia, por toda a parte, mantém tenso nosso pensamento. [...] somente se nos voltarmos pensando [passo de volta] para o já pensado, seremos convocados para o que ainda está para ser pensado [esquecimento da diferença] ${ }^{386}{ }^{387}$

Como vimos, o caminho do passo de volta do pensamento vai em direção a possibilidade deste acontecimento-apropriação entre ser e homem como ser pensante, logo, entre ser e pensar. Para isso, descrevemos que o que se exige é um salto, não em direção ao ser como fundamento, mas ao sem fundamento, ao abismo da diferença, cuja essência reside na decisão onde se consuma e impera a diferença entre ser e ente, separando-os e unindo-os, onde se inicia a história da metafísica, sua constituição onto-teológica, perpassando suas épocas e marcando a história do ser e do homem. "A constituição onto-teológica da metafísica emerge do imperar da diferença que sustenta separados e unidos ser como fundamento e ente como fundado-fundamentante, sustentação que a de-cisão consuma." 388 É no passo de volta que estabelecemos um diálogo com o pensamento, é a partir dele que o passo autêntico como acontecimento-apropriação entre ser e pensar - ser e homem, pode se dar. É neste salto que pode se abrir a possibilidade de novos caminhos e a transformação de mundo, da História do ser e da relação com o homem.

Quando o salto "na diferença ontológica [acontece], o fundamento não é mais pensado como a condição incondicionada, como a presença absolutamente constante do ser, mas como 'acontecimento apropriador'." 389 Não podendo mais perguntar pelo ser como se ele fosse um ente, Heidegger teria encontrado no

385 Heidegger, Sobre o humanismo,1973, p.347. Vale acrescentar que Heidegger acena para
diferenças entre o poetar e o pensar que não vamos desenvolver neste texto. Como acréscimo de
leitura veja Heidegger, Que é metafísica? [posfácio], (1943/1973), p.249
${ }_{386}$ Como vimos o passo de volta, passo do pensar, é justamente o movimento que "vai do
impensado, diferença enquanto tal, para dentro do que deve ser pensado. Isto é o esquecimento da
diferença." Heidegger, A constituição Onto-teo-lógica da Metafísica In. Identidade e diferença,
1973, p.391
${ }_{387}$ Heidegger, O princípio da identidade In. Identidade e diferença, 1973, p.385
388 Heidegger, A constituição Onto-teo-lógica da Metafísica In. Identidade e diferença, 1973,
p.399
${ }_{389}^{399}$ Casanova, M. Pensamento em transição: Heidegger e o outro início da filosofia In. Fenomenologia hoje IV: fenomenologia, ciência e técnica, 2013. p.285 
acontecimento a resposta para o modo como o ser se essencia, se presentifica em interpretações (determinações) possíveis e históricas do ser do ente. Isso significa que "toda determinação do ser do ente [determinação do "é" dos entes em geral] depende de um horizonte ontológico predeterminado que forneça para ela uma medida originária." ${ }^{390}$ A partir desta passagem, Casanova num diálogo com a obra heideggeriana Contribuições ${ }^{391}$ nos descreve acerca do essenciar-se do ser de modo a nos esclarecer.

O essenciar-se do ser se articula de duas formas [...] ele implica a determinação do ente na totalidade [...] o descerramento [abertura] de um horizonte ontológico transcendental e globalizante do qual provém, sobretudo, a medida do "é" dos entes que se mostram nesse horizonte. Heidegger se vale do termo "clareira" (Lichtung) para designar tal horizonte, entendido como o espaço no qual o Dasein humano habita. [...] [O segundo momento do essenciar-se] O descerramento do ser do ente na totalidade não inclui somente a abertura do ente, mas também a presença de algo que resiste a essa abertura. ${ }^{392}$

No descerramento (abertura) do ser algo sempre resiste, se oculta, se afundando no abismo da diferença. Na passagem a seguir, também de Casanova, fica mais claro este desvelamento e velamento (retração) no acontecimento apropriativo.

A noção heideggeriana de "acontecimento apropriativo" implica um movimento duplo de desvelamento e retração. O ser se essencia na medida em que se doa como determinação do ente na totalidade, mas ao mesmo tempo detém sua infinita diferença, de modo que, nessa determinação mesma, surge um aceno à retração do ser, impedindo uma plena identificação entre o ser e a determinação do ente. Toda determinação do ser do ente na totalidade se mostra, portanto, como uma determinação possível, histórica. ${ }^{393}$

No acontecimento apropriativo não é apenas o Dasein humano que é marcado por uma incompletude constitutiva (como em Ser e tempo), mas o ser mesmo passa a estar próximo desta negatividade ontológica, apontando a própria incompletude do mundo (do $D a$ ). A impossibilidade de fundamentação da totalidade às últimas consequências revela a impossibilidade de podermos ter a

\footnotetext{
390 Casanova, M. Pensamento em transição: Heidegger e o outro início da filosofia In. Fenomenologia hoje IV: fenomenologia, ciência e técnica, 2013. p.286

${ }^{391}$ Não vamos nos debruçar sobre a obra Contribuições, obra de fundamental importância para a compreensão do acontecimento apropriativo, do pensamento em transição e do outro início, uma vez que nosso objetivo é esclarecer a diferença ontológica pensada nas conferências citadas e o deslocamento da posição do homem. Neste sentido, esclarecemos e introduzimos o pensamento a diferença ontológica pensada a partir da história do ser e consequentemente do Dasein humano.

392 Casanova, M. Pensamento em transição: Heidegger e o outro início da filosofia In. Fenomenologia hoje IV: fenomenologia, ciência e técnica, 2013. p.287

393 Casanova, M. Pensamento em transição: Heidegger e o outro início da filosofia In.
} Fenomenologia hoje IV: fenomenologia, ciência e técnica, 2013. p.289 
determinação da totalidade a partir de uma noção de presença e de estabilidade. As determinações são históricas e, talvez, pudéssemos dizer mundanas. História do ser - determinações de ser - determinações de Mundo - determinação dos entes - determinação do homem. Neste repertencimento Ser - Homem pode pelo acontecimento apropriativo reconfigurar tais determinações. Casanova novamente nos esclarece:

Heidegger busca responder a questão de como se podem fundar historicamente as determinações do ser do ente na totalidade por meio da noção de "acontecimento apropriador". A abertura própria do ser se dá sempre junto à retração do ser no abismo de sua diferença e não permite, assim, uma definição última da presença do ser. $^{394}$

Em outra passagem, Casanova novamente conecta o acontecimento apropriador à fundação de épocas históricas, ou seja, "sobre o momento no qual a constituição ontológica é entendida como medida para os fenômenos ônticos em geral [e aqui o homem como ente está incluído], no qual o instante de abertura do ser do ente na totalidade se dá." ${ }^{395}$ A noção de acontecimento apropriador parte da temática das determinações históricas que já teriam ocorrido, e que seriam vistas como desapropriação do ser e do Dasein, uma vez que tomam o ser como ente e o Dasein como algo substancial e como animal racional. Interrogar a metafísica como tal, a história da metafísica, traria a necessidade de pensar algo fora de seu horizonte. E dessa forma, faria sentido à espera heideggeriana da superação e aprofundamento do horizonte epocal no qual estamos (da técnica) e o resguardo da semente do seminário A constituição Onto-teo-lógica da Metafísica quando ele nos descreve a esperança para que ela (a semente) "possa à sua maneira, pouco importa quando, nascer e frutificar."396

Fica mais claro a partir destas conferências da década de 50, em que medida o papel do homem se desloca no pensamento heideggeriano e com isso também a abertura ao ser. A abertura ao ser e a diferença ontológica não recaem (apenas) no homem de modo a possibilitar às transformações de mundo. Mas agora, o mundo, o Da, também passa a ser pensado a partir desta diferença. A história seria resultado de um apelo do ser instaurando o que se entende pela História do ser ou

\footnotetext{
${ }^{394}$ Casanova, M. Pensamento em transição: Heidegger e o outro início da filosofia In. Fenomenologia hoje IV: fenomenologia, ciência e técnica, 2013. p.294

${ }^{395}$ Casanova, M. Pensamento em transição: Heidegger e o outro início da filosofia In. Fenomenologia hoje IV: fenomenologia, ciência e técnica, 2013. p.297-298

${ }^{396}$ Heidegger, A constituição Onto-teo-lógica da Metafísica In. Identidade e diferença, 1973, p.400
} 
Épocas da Verdade do ser, como o Ser se ilumina num determinado horizonte. É assim que o autor alemão vai compreender a dação historial do ser: "physis, logos, hén idéa, energéia, substancialidade, objetividade, subjetividade, vontade, vontade de poder, vontade de vontade." ${ }^{397}$ Este modo destinal em que o ser se dá, acontece, "se determina por si próprio, através do modo como se revela. Este modo, entretanto, é historialmente destinado, é um cunho sempre epocal que para nós somente acontece e impera se o liberamos para aquilo que, do que foi e continua sendo, lhe é próprio." ${ }^{398}$ Como vimos, esta liberação vai em direção à diferença impensada. O papel do Dasein humano é deslocado, mas nem por isso deixa de ser privilegiado. O homem não passa a ser algo presente como uma substância, ele continua sendo aberto ao ser e participando da abertura do ser. Fica clara esta relação de estar na abertura e da própria abertura do ser do homem na passagem a seguir retirada dos Seminários de Zollikon de 1965.

Em Ser e tempo, a questão do ser determina tudo, isto é, a questão em que medida o ser (presença) tem seu estado de abertura no tempo. Mas como o homem só pode ser homem compreendendo o ser, isto é, estando na abertura do ser, o ser homem como tal é assinalado [privilegiado] pelo fato de ele mesmo ser esta abertura à sua maneira. ${ }^{399}$

Para pensarmos uma relação no que diz respeito à psicologia e os humanos seria, para o autor alemão, necessário ir ao encontro deste pensamento, deste movimento do pensar, do passo de volta, de um lembrar da esquecida diferença e com isso, do próprio movimento de destinação do Ser como História do Ser. E não seria de certo modo isso que Heidegger fala no Seminário de Zollikon de 8 de julho de 1965:

Quem, pois, [...] ainda quiser conservar alguma reflexão, quem se dedica hoje em dia à profissão de ajudar as pessoas psiquicamente enfermas, deve saber o que acontece; deve saber onde está historicamente; precisa esclarecer-se diariamente que aqui está operando um destino antigo do homem europeu; ele precisa pensar de maneira histórica e abandonar a absolutização incondicional do progresso em cujo rastro o ser-homem ocidental ameaça sucumbir. ${ }^{400}$

Sem dúvida Heidegger está pensando a possibilidade de outros dizeres. Ele atrela estes destinos à História do Ser, à história metafísica e à história ocidental. Como se os limites de um dito ocidente se dessem pela diferença entre ser e ente,

\footnotetext{
${ }^{397}$ Heidegger, A constituição Onto-teo-lógica da Metafísica In. Identidade e diferença, 1973, p.397

${ }^{398}$ Heidegger, A constituição Onto-teo-lógica da Metafísica In. Identidade e diferença, 1973, p.397

${ }_{399}$ Heidegger, Seminários de zollikon, 2001, p.147

${ }^{400}$ Heidegger, Seminários de zollikon, 2001, p.129 (Grifado nosso)
} 
entre os destinos do ser e o "é" contido em cada um deles. Estes limites se dariam pela diferença subtraída e assim (im)pensada, destinada, manifestada a partir da consumação da decisão que une e separa algo como ente e ser. O pensar seria um pensar de uma história do pensamento que seria História do ser e da essência da metafísica enquanto esta dação de ser manifestada em interpretações do ente enquanto tal, interpretações estas que Heidegger nomeará a partir das vozes de grandes pensadores: physis, lógos, hén, idéa, enérgeia, substancialidade, objetividade, subjetividade, vontade, vontade de poder, vontade de vontade. O que ganha voz no pensamento de Heidegger é a própria diferença como este abismo de retração do ser. Ele, o ser, não mais pode ser visto apenas como presença total, mas ao mesmo tempo que determina e se manifesta em interpretações do ente, se retrai no abismo da diferença que os sustenta (ser e ente). O que talvez pudéssemos questionar é se estas delimitações seriam tão claras? Seria a história do ser marcada pela subtração e esquecimento da diferença enquanto tal, da diferença entre ser e ente, como algo insuprimível ${ }^{401}$ ? Seria a história do ser a nossa história? Nossa? A espera por outros dizeres estaria fora de nossa época e das épocas já vividas? Estaríamos nós fadados aos destinos e as épocas do ser? Quem estaríamos? Pensar tais limites entre ser e ente nos coloca questões antes, talvez, nunca trazidas pelo pensamento; mas dizer que estas questões abarcam toda a história da metafísica? A nossa história humana? Ou talvez apenas a história do nosso ocidente?

Como pensar este nós a partir de uma medida ontológica de interpretação do ente enquanto tal? Seria esta medida total? Ainda que o ser se retraia, ainda estaríamos determinados por horizontes delimitados por este jogo entre ser e ente, estes limites (medidas) que marcam e delimitam (nossa) história, a história do ocidente? A retração do ser, não mais como presença constante, marcaria, talvez a possibilidade de outra época, de outra clareira, outra determinação possível do ente na totalidade. Mas ainda estamos (nós) marcados pela diferença que sustenta, une e consuma a diferença entre ser e ente. Ainda nos limites de tal diferença nomeada, demarcada. Será que conseguimos nos aproximar destes limites? Podemos fazê-los tremer? Alargá-los? O capítulo seguinte vai buscar acenar para

\footnotetext{
${ }^{401}$ Ernildo Stein In. Heidegger, A constituição Onto-teo-lógica da Metafísica In. Identidade e diferença, 1973, p.396 [nota 6 de pé de página]
} 
este alargamento a partir do pensador Jacques Derrida tendo em vista o que chamamos de humano a partir do pensamento do rastro (Trace).

Vimos assim que neste segundo capítulo pudemos desenvolver inicialmente a analítica existencial do Dasein tendo em vista seus elementos estruturais com o intuito de tentarmos repensar a essência do humano a partir da abertura ao ser como essência da existência humana apresentada já em Ser e tempo. A noção de cuidado como unidade essencial deste ente que nós mesmos somos e a possibilidade de conquista de seu carater de poder-ser-no-mundo como Dasein antecipador-resoluto dão a este ente uma outra relação com a responsabilidade sobre si mesmo e sobre os demais entes, uma vez que ele não se encontra mais fechado para sua própria essência existencial, mas se conquista como poder-serno-mundo. Como modo de ser possível ele também pode novamente decair no modo de ser impessoal cotidiano. Após a apresentação dos elementos necessários para se compreender a unidade essencial do Dasein humano. Tentamos desdobrar a maneira como Heidegger passa a compreendê-lo nos textos mais tardios e os elementos que entram em jogo neste pensamento após a década de trinta, apresentando em seguida um diálogo entre o autor e psicoterapeutas sobre o humano e seu caráter mais próprio.

Num texto sobre o humanismo desenvolvido em carta Sobre o humanismo (1947) Heidegger se posiciona mais claramente acerca da necessidade de atentarmos para o esvaziamento da linguagem e do pensar [do ser] o que ameaçaria a essência do Dasein humano. Esquecidos do ser, estamos perdidos e desumanizados, uma vez que não compreendemos nossa própria essência. A essência do humano e o pensamento dos destinos do ser se relacionam nesta obra de forma mais clara e direta que em Ser e tempo. Os destinos do ser determinam cada condição humana. Os humanismos característicos de um pensamento moderno não levam em conta o ser, os destinos do ser, a verdade do ser, nem a essência do humano como existência - abertura ao ser. Todos estes elementos se encontram imbricados nesta obra e são desenvolvidos tendo em vista que o humano a partir da virada heideggeriana teria perdido seu papel singular arquimediano de transformação do mundo para ser pensado como pastor e guardião do ser. Em Seminários de Zollikon desenvolvemos um diálogo mais claro com a psicoterapia e com a possibilidade de se compreender este humano a partir de sua essência existencial como compreensão e abertura ao ser 
determinada a partir dos destinos do ser. É nesse sentido que Heidegger nos (nós profissionais que tratam dos psiquicamente enfermos) chama a atenção para que pensemos sobre o ser, sobre o esquecimento do ser, sobre o destino que perpassa a Europa e para que possamos compreender o humano como humano e não desumano. Acenando, assim, para a necessidade destes profissionais se tomarem como Dasein para a compreensão da saúde e da enfermidade.

Com o deslocamento do papel do Dasein humano nas obras de Heidegger a negatividade ontológica passa a ser pensada a partir do próprio mundo tendo em vista a noção de acontecimento apropriador e da diferença ontológica. Nesta parte final do capítulo tentamos abordar, ainda que brevemente, como Heidegger passa a compreender as transformações de mundo a partir de interpretações do ser do ente. Interpretações nomeadas a partir das vozes de grandes pensadores: physis, lógos, hén, idéa, enérgeia, substancialidade, objetividade, subjetividade, vontade, vontade de poder, vontade de vontade. Onde o Ser se dá e se retrai, se essenciando (presentificando) em interpretações possíveis (históricas) do ser do ente. A partir deste segundo capítulo vamos abrir um espaço para repensar e desdobrar este nós - Dasein humanos cuja essência é marcada pela abertura ao ser. Repensando, sobretudo, os possíveis limites das interpretações do ser do ente em um destino histórico do ser cuja medida ontológica determina todos os entes inclusive nós Dasein humano. 


\section{3}

\section{Derrida: diálogos com Heidegger}

Este capítulo tem como objetivo apresentar uma leitura de Derrida sobre Heidegger tendo em vista nossa temática acerca do repensar sobre o humano. Derrida é um autor do pensamento do rastro, do pensamento da desconstrução. A partir de suas leituras e de sua história ele acena para um alargamento, uma desconstrução do pensamento tradicional, fazendo tremer as bases e os limites que os sustentavam. Apontando, muitas vezes, para aqueles que não estariam incluídos dentro das bordas dos textos e dos discursos dos pensadores. Pois, justamente neste movimento de fechamento acabariam excluindo outros que estão fora, demarcando os limites de seu entre. Derrida é um leitor de Heidegger por quem tem grande admiração e respeito. Nesse sentido, ele nos traz à necessidade de passarmos pelo pensamento do autor alemão para podermos desdobrar o pensamento dele mesmo.

Mas no momento em que alguém expõe/esclarece Heidegger de modo crítico ou desconstrutivo, não deve também reconhecer uma certa necessidade de seu pensamento, seu caráter inaugural em tantos aspectos e sobretudo aquilo que tem de porvir para nós em seu deciframento? ? $^{402}$

\section{1}

\section{Metafísica da presença: logocentrismo}

O objetivo deste subcapítulo será descrever e pensar o que Derrida compreende acerca do que ele chama de logocentrismo e em que medida este estaria relacionado ao que ele chama de metafísica da presença, do próprio e da identidade. O logocentrismo é um ponto central no pensamento derridiano e base para pensarmos sua relação com o que compreendemos por humano. Em sua obra De la Gramatologie (1967), entre as primeiras e mais importantes, podemos começar a trilhar seu caminho a partir do problema da linguagem e do que ele chama de écriture, traduzido como escritura. Haveria hoje uma inflação do "signo" linguagem, na medida em que o problema da linguagem nos invadira, mas esta inflação seria a "inflação do próprio signo, a inflação absoluta, a inflação

\footnotetext{
${ }^{402}$ Derrida, Heidegger, l'enfer des philosophes in. Point de suspension, (1987/1992), p.196
} 
mesma." ${ }^{403}$ Assim, o autor nos diz que tudo se passa como se o conceito ocidental de linguagem, e aqui estamos apontando a língua fonética em geral, fosse tomado como uma linguagem primeira, mais fundamental e original e a escrita fosse, assim, algo derivado dela. O que Derrida tenta assinalar é que o logos e a phoné sempre estiveram intimamente e originariamente relacionados, ou seja, existiria uma proximidade entre phoné e logos que denunciaria uma relação com o sentido, com o dizer e a reunião. Uma vez que a $v^{4} z^{404}$ seria produtora do primeiro significante e estaria, então, mais próxima do significado, do sentido e, assim, da verdade. Na medida em que se ouve o que se diz, existe uma proximidade ("reunião") entre o dito e ouvido, marcando um sentido, um significado, Um. Dessa forma, à escrita restaria uma posição mais derivada, um significante não originário. Nesse sentido, Derrida nos descreve: "Tal noção [de signo e de sua distinção entre significado e significante] permanece, portanto, na deiscência deste logocentrismo que é também um fonocentrismo ${ }^{405}$ : proximidade absoluta da voz e do ser, da voz e do sentido do ser, da voz e da idealidade do sentido." ${ }^{406}$ Seria esta diferença entre significado e significante que pertenceria a história da metafísica e marcaria as diversas oposições e distinções como o sensível e inteligível... Onde o inteligível seria na época medieval, por exemplo, o logos absoluto e, talvez, por isso, Derrida nos diz que "o signo e a divindade têm o mesmo local e a mesma data de nascimento." ${ }^{407}$ Poderíamos questioná-lo dizendo que o signo teria sido tematizado recentemente, cerca de um século, e não poderia estar de modo algum neste lugar de marca da história da metafísica. O que está em jogo aqui, e Derrida deixa claro, é a própria diferança (differánce) apagada, não se trata de colocá-la como um conceito que deve ser posto no lugar da verdade presente ou pensarmos o signo como algo de que devemos nos livrar. Mas o gesto do jogo é o gesto do que Derrida compreende como escritura, uma derivação, talvez, mas não de algo mais original, mas como seu próprio movimento em jogo.

\footnotetext{
${ }^{403}$ Derrida, Gramatologia, 2004, p.7

${ }^{404}$ Derrida retoma Aristóteles (Gramatologia, 2004,p.13 e 14)

${ }^{405}$ Nós vamos notar e Derrida nos adverte que “já se pressente portanto que o fonocentrismo se confunde com a determinação historial do sentido do ser em geral como presença, [...] o logocentrismo seria, portanto, solidário com a determinação do ser do ente como presença. Na medida em que um tal logocentrismo não está completamente ausente do pensamento heideggeriano, talvez, ele ainda o retenha nesta época da onto-teologia, nesta filosofia da presença, isto é na filosofia." (Derrida, Gramatologia, 2004, p.15)

${ }^{406}$ Derrida, Gramatologia, 2004, p.14

${ }^{407}$ Derrida, Gramatologia, 2004, p.16
} 
E por isso, a escritura aqui compreenderia a própria linguagem, não mais pensada como decaída, mas uma origem que se apaga a si mesma na sua própria produção: origem da origem. Um apagamento a afetar-se desde o início do jogo.

O advento da escritura é o advento do jogo: o jogo entrega-se hoje a si mesmo, apagando o limite a partir do qual se acreditou poder regular a circulação dos signos, arrastando consigo todos os significados tranquilizantes, reduzindo todas as praças-fortes, todos os abrigos do fora-de-jogo que vigiavam o campo da linguagem. Isto equivale, com todo rigor, a destruir o conceito de "signo" e toda sua lógica. Não é por acaso que esse transbordamento sobrevém no momento em que a extensão do conceito de linguagem apaga todos os seus limites. Como veremos: esse transbordamento ${ }^{408}$ e esse apagamento têm o mesmo sentido, são um único e mesmo fenômeno. ${ }^{409}$

Mas como podemos nos aproximar um pouco mais do que Derrida chama de signo $^{410}$ ? Veremos aos poucos sua relação com a escritura e a diferança. Segundo Derrida, podemos compreender usualmente por signo o colocar-se em lugar da coisa presente, do ente-presente. O signo representaria, então, o presente na sua ausência, uma vez que o signo é usado quando não podemos mostrar/tomar a coisa presente. Significamos quando não temos a coisa. Derrida então nos diz "o signo seria a presença diferida." ${ }^{411} \mathrm{O}$ signo viria como uma coisa secundária e derivada substituir a presença original da coisa que estaria ausente. Questionar a derivação do signo seria questionar a autoridade da presença (ou seu oposto simétrico: a ausência) e mostrar que a diferança seria, talvez, mais "originária", uma origem sem origem, na medida em que origem, arquia, telos ... fazem parte da lógica da presença. Questionar a autoridade da presença seria questionar-se acerca do limite que nos levou "a formar o sentido do ser em geral como presença e ausência nas categorias do ente ou da ente(i)dade [étantité e não entité]." ${ }^{.412} \mathrm{O}$ próprio Derrida sugere que esta questão nos levaria a questão heideggeriana e que, talvez, a diferança nos reconduziria a própria diferença ôntico-ontológica ${ }^{413}$.

Aos poucos vamos ver como a diferança e a escritura estão intimamente relacionadas. Derrida dedica um texto apresentado numa Conferência na

\footnotetext{
${ }^{408}$ Talvez fique mais claro o que Derrida chamou de inflação da linguagem, do signo. Uma inflação que transborda e se apaga. "Não é por acaso que esse transbordamento sobrevém no momento em que a extensão do conceito de linguagem apaga todos os seus limites." Derrida, Gramatologia, 2004, p.8

409 Derrida, Gramatologia, 2004, p.8 (Grifado nosso)

${ }^{410}$ Derrida tem um extenso diálogo com a semiologia e a linguística, sobretudo com Saussure. No entanto, não vamos nos aprofundar nesta relação que, apesar de muito rica, não é nosso foco. Veja Gramatologia (1967/2004), A Diferença (1968/1991),

411 Derrida, A Diferença In. Margens da filosofia, 1991, p.40

412 Derrida, A Diferença In. Margens da filosofia, 1991, p.41

${ }^{413}$ Derrida, Gramatologia, 2004, p.29
} 
Sociedade Francesa de Filosofia (1968) intitulado A diferença onde ele nos esclarece acerca deste "termo"- différance - tão frequente em seu pensamento. Vamos por isso, também nos debruçar rapidamente sobre ele para o compreendermos e o entregarmos novamente a marcha do nosso texto, deixando um pouco mais claro o que com ele estava em jogo. A palavra differánce possui em si a troca (na língua francesa) da letra $a$ pela letra $e$, esta diferença gráfica permanece gráfica, uma vez que não se ouve a diferença entre elas (différence e différance) e tampouco se entende (entendre: ouvir ou compreender na língua francesa) esta diferença. Esta marca (troca do $a$ pelo $e$ ) muda e silenciosa, é o túmulo do próprio no qual se produz a própria diferança. ${ }^{414}$ Túmulo que não pode ser ressoado, a não ser que no discurso seja acentuado tal diferença ( $a$ e $e$ ). Este silêncio, este inaudível nos remete a uma ordem que não pertence mais às oposições metafísicas: sensível - inteligível, por exemplo, mas que resiste a ela, resiste por que a sustenta, "anuncia-se num movimento de diferança (com um a) entre duas diferenças ou entre duas letras, diferança que não pertence nem a voz nem a escrita no sentido corrente" ${ }^{\text {415 }}$. Veremos aos poucos que a diferança não pode ser exposta, pois não se manifesta nem se torna presente, não sendo, dessa forma, um ente e, nesse sentido, tampouco podemos dizer que a diferança $e$, visto que ela não é ente, não é presente, não tem essência nem existência. É irredutível a reapropriação e, por isso, túmulo do próprio, dela não se apropria, de modo que o próprio não se alcança, mas transborda e se apaga neste feixe de diferança. Não tem começo nem fim, não sendo teleológica, dificultando saber por onde começar a traçar sua tessitura e entrelaçamento. Derrida inclusive nos mostra que ela deverá - poderá ser superada, assim ele nos descreve, a "diferança pode muito bem, deverá um dia ser superada, prestar-se por si mesma, se não a sua própria substituição, pelo menos ao seu encadeamento numa cadeia que na verdade, ela não terá jamais governado." ${ }^{\text {416 }}$ Não governa pois não tem a si mesmo como um fim e tampouco se apropria de si, não sendo da ordem da reunião, nem do pertencimento, nem do Um (da unidade). Ela é polissêmica e remetente, na medida em que remete, se endereça, reenvia às diferentes significações. Não é ativa nem passiva, carregando na própria palavra (différance) a terminação ance

\footnotetext{
${ }^{414}$ Derrida, A Diferença In. Margens da filosofia, 1991, p.35

${ }^{415}$ Derrida, A Diferença In. Margens da filosofia, 1991, p.36

${ }^{416}$ Derrida, A Diferença In. Margens da filosofia, 1991, p.38
} 
que em francês fica entre a passividade e a atividade. ${ }^{417}$ A diferança não é um conceito nem uma palavra, não sendo autorreferente, mas refere-se à, "é" e faz parte do jogo de diferenças como efeitos, na medida em que os efeitos ou diferenças como efeitos não surgem do nada, prontos, neutros, puros, mas estão inscritos no próprio jogo, que é também o jogo da escritura descrito na passagem anterior. Jogo no qual quem perde ganha e quem ganha perde. Uma vez que não há em si puro, nem rompimento total, tampouco destruição total ou morte absoluta, não há, por isso, próprio. Veremos que escritura e diferança andam de mãos dadas. As duas passagens a seguir nos esclarecem acerca da diferança: "Designaremos por diferança o movimento pelo qual a língua, ou qualquer outro código, qualquer esquema de reenvios em geral se constitui "historicamente" como tecido de diferenças." ${ }^{418}$

O que se escreve diferança será, portanto, o movimento de jogo que "produz", por meios do que não é simplesmente uma atividade, estas diferenças, estes efeitos de diferença. Isto não significa que a diferança que produz as diferenças seja anterior a elas, num presente simples e, em si, imodificado, indiferente. A diferança é a "origem" não-plena, não-simples, a origem estruturada e diferente das diferenças. O nome de "origem", portanto, já não lhe convém. ${ }^{419}$

Voltemos um pouco à relação fala - escrita, trabalhada por Derrida. Num diálogo com Saussure, no qual não vamos nos aprofundar, o autor francomagrebino mostra em que medida a escrita estaria sempre numa posição secundária, derivada e representativa da língua falada que, por sua vez, seria original e plena. Derrida acentua que já havia em Platão ${ }^{420}$ e Aristóteles este modelo de escritura fonética e da linguagem de palavras que será retomado por Saussurre. A definição de Aristóteles já nos mostraria o que Derrida chama do privilégio da fala sobre a escrita: “Os sons emitidos pela voz são os símbolos dos estados da alma, e as palavras escritas, os símbolos das palavras emitidas pela voz." A estrutura fonética refletiria e nos serviria para uma episteme em geral, ligando conhecimento, consciência, fala, logos, verdade. A fala é colocada num lugar natural, originário enquanto a escrita seria representativa da fala e viria como que de fora usurpar, transformar de maneira negativa, desnaturalizar o dentro da fala, sua natureza originária que nos seria tão próxima e própria.

\footnotetext{
${ }^{417}$ Derrida, A Diferença In. Margens da filosofia, 1991, p.40

${ }^{418}$ Derrida, A Diferença In. Margens da filosofia, 1991, p.43 (Grifado nosso)

${ }^{419}$ Derrida, A Diferença In. Margens da filosofia, 1991, p.43

${ }^{420}$ Derrida aponta a passagem em Fedro onde Platão diria que o mal da escritura vem do fora (275a apud Derrida, 2004, p.42)
} 


\section{"Externo/interno, imagem/realidade, representação/presença, tal é a velha grade a que está entregue o desejo de desenhar o campo de uma ciência."}

Em outra passagem, Derrida nos chama a atenção para este jogo de oposições, característico da metafísica e que estariam, de algum modo inscritos no jogo da diferança e escritura.

Poder-se-ia assim retomar todos os pares de oposição sobre os quais está construída a filosofia e dos quais vive o nosso discurso para aí vermos, não apenas a oposição, mas anunciar-se uma necessidade tal que um dos termos apareça aí como diferança do outro, como o outro diferido na economia ${ }^{422}$ do mesmo (inteligível como diferante do sensível, como sendo diferido; o conceito como intuição diferida - diferante; a cultura como natureza diferida - diferante; todos os outros da physis - tekhnê, nomos, thesis, sociedade, liberdade, história, espírito, etc. - como physis diferante. ${ }^{423}$

Um pecado instaurado e a busca pela salvação, uma pureza natural e uma perversão "histórica", relações de um fora e um dentro e nesse sentido Derrida nos descreve que "não é uma simples analogia: a escritura, a letra, a inscrição sensível, sempre foram consideradas pela tradição ocidental como o corpo e a matéria exteriores ao espírito, ao sopro, ao verbo e ao logos." 424 O que entendemos por escritura aqui compreenderia a fala, ou seja, ela abrangeria o campo da linguagem, abrindo a possibilidade da própria fala ${ }^{425}$. O que Derrida tenta nos mostrar e isso é um dos movimentos de seu trabalho e nossa dificuldade em lê-lo, é que esta usurpação teria desde sempre começado, haveria assim uma violência "originária" da escritura ou, o que daria no mesmo, uma violenta escritura "originária". Uma vez que escritura e violência andam juntas. Não haveria desta forma, para o autor nenhuma inversão de papeis, no sentido de apontar agora uma outra origem mais originária que aquela, uma outra pureza mais pura, um pensamento que pensa ou uma verdade mais verdadeira. A verdade, a pureza, o natural, o neutro foram desde sempre violentados, há desde sempre violência. A escritura é esta violência e a metafísica um sistema de defesa. "O errante [...] nunca deixou de perseguir a linguagem como sua primeira e mais

\footnotetext{
${ }^{421}$ Derrida, Gramatologia, 2004, p.41 (Grifado nosso)

${ }^{422}$ Economia está relacionada ao que Derrida chama de cálculo, lógica, reunião, mas também com sentido e finalidade.

${ }^{423}$ Derrida, A Diferença In. Margens da filosofia, 1991, p.50

${ }^{424}$ Derrida, Gramatologia, 2004, p.42

${ }^{425 ، E l a ~[e s c r i t u r a] ~ t a m b e ́ m ~ a b r a n g e ~ o ~ c a m p o ~ d a ~ f a l a ~ n a ̃ o-e s c r i t a . ~ I s s o ~ q u e r ~ d i z e r ~ q u e, ~ s e ~ e ́ ~ p o s s i ́ v e l ~}$ ligar a violência à escritura, a escritura aparece bem antes da escritura no sentido estrito: já na diferança ou na arquiescritura que abre a própria fala.” (Derrida, Gramatologia, 2004, p.157)
} 
íntima possibilidade.” ${ }^{426}$ Quanto a esta relação fala (dentro) escritura (fora), modificação maléfica de um sistema natural e verdadeiro. Com que direito se exclui este fora? Derrida nos descreve:

Declaração de princípio, voto piedoso e violência histórica de uma fala sonhando sua plena presença a si [produzindo a metafísica logocêntrica],vivendo a si mesma como sua própria reassunção: autodenominada linguagem, autoprodução da fala viva, capaz, dizia Sócrates, de se dar assistência a si mesma, logos que acredita ser para si mesmo seu próprio pai, elevando-se assim acima do discurso escrito, infans e enfermo por não poder responder quando é interrogado e que tendo "sempre necessidade da assistência de seu pai" (Fedro 275d) deve pois ter nascido de um corte de uma expatriação primeira, consagrando-o à errância, ao cegamento, ao luto. Autodenominada linguagem mas fala iludida ao se crer totalmente viva e violenta por não ser "capaz de se defender" a não ser expulsando o outro e primeiramente, o seu outro, precipitando-o fora e abaixo sob o nome de escritura. ${ }^{427}$

O que é colocado em xeque neste gesto é o privilégio, o privilégio de um discurso abrigado, tranquilo, idealizado, próprio, puro, neutro numa extremidade e na prepotência de não pertencer ao jogo. Enclausurando aqueles que pertencem e reduzindo-os ao discurso de uma verdade sem limites, pois limita todo o resto, ditando e apontando todo o horizonte a partir do qual discursa. Este gesto, diria-se neutro para poder se auto dizer, é o gesto também de um divino, do pai, de uma totalidade natural, da origem, da essência, da verdade e do que Derrida chama também de livro. Em que se protege contra a disrupção da escritura, da diferença em geral. O privilégio de uns: pai, homens, seres humanos, ciência, verdade, $\operatorname{logos}$, ser ... em relação a outros: crianças, enfermos, loucos, mulheres, minorias diversas, mito, literatura, animal ... Este gesto fala e protege também o logocentrismo e o fonocentrismo, o privilégio da phoné como lugar originário de proximidade absoluta da voz e do sentido de ser, num ouvir-se falar em que "o sujeito afeta-se a si mesmo e refere-se a si no elemento da idealidade. ${ }^{, 428} \mathrm{O} \log$ os, a voz e a presença estariam, segundo Derrida, interligados no pensamento da metafísica.

O logos apenas pode ser infinito e presente a si, apenas pode produzir-se como auto-afeção, através da voz: ordem de significante pelo qual o sujeito sai de si em si, não toma fora de si o significante que ele emite e que o afeta ao mesmo tempo. Tal é pelo menos a experiência - ou consciência - da voz: do ouvir-se falar. ${ }^{429}$

\footnotetext{
${ }^{426}$ Derrida, Gramatologia, 2004, p.53

${ }^{427}$ Derrida, Gramatologia, 2004, p.48 (Grifado nosso)

${ }^{428}$ Derrida, Gramatologia, 2004, p. 15

${ }^{429}$ Derrida, Gramatologia, 2004, p.122 - Derrida está se referindo mais especificamente nessa passagem à metafísica pós cartesiana, com a experiência da consciência como pura afeção.
} 
Desta forma, o fonocentrismo e o logocentrismo seriam solidários ao sentido de ser como presença: como eidos, como substância/essência/existência, como agora ou instante, como presença a si do cogito, como consciência, subjetividade etc. A metáfora destes discursos e de muitos outros confirma "o privilégio do logos e funda o sentido "próprio" dado então à escritura: signo significante de um significante significante ele mesmo de uma verdade eterna, eternamente pensada e dita na proximidade de um logos presente. ${ }^{, 430}$ Podemos pensar o sentido "próprio" de escritura como a metaforicidade ${ }^{431}$ mesma. Acentuando a metáfora da subjetivividade, Derrida nos descreve que na história das metáforas, um corte decisivo pareceu acontecer "no momento em que se constitui, ao mesmo tempo que a ciência da natureza, a determinação da presença absoluta como presença a si, como subjetividade." ${ }^{432}$ Um corte metafórico que herdamos até hoje e que possui reverberações de seus efeitos, sobretudo, no campo da psicologia e das ciências humanas.

Este gesto que questiona o privilégio, questiona ao mesmo tempo a propriedade do próprio, a proximidade do próprio, o pertencimento, a reunião, o próprio e o próximo. Na constante tentativa do discurso filosófico de se auto dizer, de se auto nomear, apontando seus limites e incluindo, apropriando-se de seu próprio. Para a filosofia, Derrida nos descreve "era necessário que o seu próprio limite não lhe permanecesse estranho. Apropriou-se, portanto do conceito dele, acreditou-se dominar a margem do seu volume e pensar o seu outro." ${ }^{, 433} \mathrm{O}$ que seria este outro para a filosofia? O autor continua, "o seu outro: o que a limita e aquilo que ela supera na sua essência, na sua definição, na produção." ${ }^{\text {"34 }}$ Neste texto, Timpanizar a filosofia (1972/1991), Derrida estará tratando, sobretudo, acerca das margens da filosofia, nome dado à obra na qual este texto se elabora. Trata-se do limite, e deste limite como passagem, do tímpano como esta membrana que limita, converte, transmite e deixa passar vibrando e reverberando os sons que lhe são endereçados, transmitidos. Um dos caminhos que se traça neste texto é descrever a relação deste outro como limite, como estranho e sua

\footnotetext{
${ }^{430}$ Derrida, Gramatologia, 2004, p.18

${ }^{431}$ Pensada como esta substituição como cadeia de substituições sem origem. "Nunca houve senão escritura; nunca houve senão suplementos, significações substitutivas que só puderam surgir numa cadeia de remessas diferenciais.” (Derrida, Gramatologia, 2004, p.194)

${ }^{432}$ Derrida, Gramatologia, 2004, p.20

${ }^{433}$ Derrida, Timpanizar a filosofia In. Margens da filosofia, 1991, p.11

${ }^{434}$ Derrida, Timpanizar a filosofia In. Margens da filosofia, 1991, p.11
} 
Necessidade de apropriação, inclusão, pertença, tornando-se apropriado, próprio e, com isso, perdendo o outro como outro. "Ao pensá-lo [o outro] como tal, ao reconhecê-lo, perdemo-lo." ${ }^{435}$ E mais à frente no mesmo texto ele afirma: "Porque assim se entende o ser: o seu próprio ${ }^{436}$. Ele assegura sem descanso o movimento superador da reapropriação." ${ }^{437}$ Pensar o limite/passagem é também pensar as margens de um discurso, neste caso no texto, Derrida trabalha em cima do discurso filosófico. Pensar suas margens seria desequilibrar ${ }^{438}$, deslocar, alargar, interrogar sua pretensa homogeneidade, aparente unicidade ${ }^{439}$. Esta tendência interiorizante (controladora), excede-o [limite] e guarda-o em si, funciona, assim, como uma resistência à desconstrução ${ }^{440}$. E a desconstrução, outro termo derridiano, por sua vez, trabalha justamente em cima destas margens, desequilibrando seus eixos, relembrando que para além do texto filosófico não há mata virgem, mas outros textos, mais textos, "um tecido de diferenças de forças sem nenhum centro de referência presente [...] mas também que o texto escrito da filosofia excede e faz quebrar o seu sentido." ${ }^{441}$ Movimento parecido com este que descrevemos do transbordar e apagar da escritura. O que se buscará introduzir, nos chama atenção Derrida, é um novo jogo, o da articulação da diferença. $^{442}$

Então, o autor questiona, este lugar da verdade, este lugar da presença e do logos, da unidade e da reunião, do a si que quer se impor jogando a si mesmo para fora do jogo ou num mesmo gesto apontando os malefícios daquele que vem usurpar sua originária natureza e essência. $\mathrm{O}$ gesto derridiano do pensamento da escritura e da diferança andam de mãos dadas com o que o autor chama de rastro (Trace). O rastro, assim como outros elementos de seu pensamento, é de difícil descrição. Uma vez que não se pode apalpá-lo, nem apreendê-lo. Sua dificuldade e seu questionamento se encontram, também, neste nosso modo de descrever e compreender os textos, as coisas, querendo apreendê-las, como tentamos fazer

\footnotetext{
${ }^{435}$ Derrida, Timpanizar a filosofia In. Margens da filosofia, 1991, p.12

${ }^{436}$ Derrida acena para a proximidade do sentido do ser na fala em Heidegger, Cf. Derrida, Timpanizar a filosofia In. Margens da filosofia, 1991, p.20

${ }^{437}$ Derrida acena para a proximidade do sentido do ser na fala em Heidegger, Cf. Derrida, Timpanizar a filosofia In. Margens da filosofia, 1991, p.17 (Grifado nosso)

${ }^{438}$ Derrida, Timpanizar a filosofia In. Margens da filosofia, 1991, p.16

${ }^{439}$ Cf. Derrida, Timpanizar a filosofia In. Margens da filosofia, 1991, p.17

${ }^{440}$ Cf. Derrida, Timpanizar a filosofia In. Margens da filosofia, 1991, p.21

${ }^{441}$ Derrida, Timpanizar a filosofia In. Margens da filosofia, 1991, p. 25

${ }^{442}$ Derrida, Timpanizar a filosofia In. Margens da filosofia, 1991, p.30
} 
agora. O rastro fala de uma instância que está sempre se remetendo, se endereçando, remessas não naturais, nem reais, menos ainda verdadeiras. O rastro

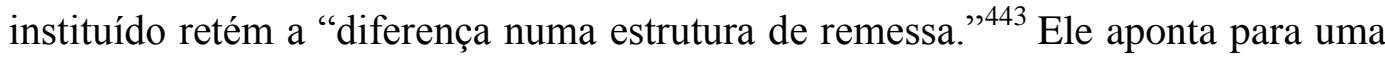
instância que não pode mais se remeter a uma origem ou a um presente transcendental e não pode tampouco entrar neste lugar como fórmula metafísica para um conceito científico de escritura. Não há como fazer ciência com o que se compreende aqui por escritura.

Derrida nos dá uma possível justificativa da escolha da palavra rastro em sua obra Gramatologia. O autor deixa claro que a justificativa jamais poderia ser absoluta, definitiva ou total, mas responderia a uma tradução de um número de discursos contemporâneos com os quais entendemos contar. Dialogando com o conceito de rastro trazido por Levinas ${ }^{444}$ e com o qual não vamos abrir aqui um diálogo, Derrida nos descreve que "tornar enigmático o que se crê entender sob os nomes de proximidade, de imediatez, de presença (o próximo, o próprio e o prede presença) [também nos discursos heideggerianos], tal seria, pois, a intenção última do presente ensaio. A desconstrução da presença passa pela da consciência. ${ }^{445} E$ É interessante que Derrida associa o rastro a uma abertura da primeira exterioridade em geral, “a enigmática relação do vivo com seu outro e de um dentro com um fora: o espaçamento." ${ }^{446}$ A partir dos termos derridianos, veremos como, de alguma forma, o autor acaba por relacioná-los a uma abertura, não ao ser ou do ser, como em Heidegger, mas ao outro, à diferença, à alteridade radical, ao transbordamento de limites, àquilo que não está incluído na pretensa unidade, que foge a toda tentativa de inclusão. Ontologia, abertura ao ser seriam ainda uma forma de redução do rastro.

Nesse sentido, ainda sobre o rastro, podemos dizer que ele fala de uma relação ao outro e de uma linguagem como escritura, é a partir dele que as oposições metafísicas seriam possíveis. A escritura como Arquiescritura ${ }^{447}$ fala do mais temível da diferença, ela treme e traz o tremor, ameaça as praças fortes, o desejo da fala viva de se auto presenciar. É o próprio movimento da diferança abrindo a possibilidade da relação ao outro, da linguagem, como condição de todo

\footnotetext{
${ }^{443}$ Derrida, Gramatologia, 2004, p.57

${ }^{444}$ Veja Levinas, Autrement qu'être ou au- delà de l'essence, 1974.

445 Derrida, Gramatologia, 2004, p.86 (Grifado nosso)

446 Derrida, Gramatologia, 2004, p.87

447 "Ela é aquilo mesmo que não se pode deixar reduzir à forma da presença." (Derrida, Gramatologia, 2004, p.69)
} 
sistema linguístico, sem fazer parte dele, mas também não tendo seu lugar num outro sítio determinável. ${ }^{448} \mathrm{O}$ que está em jogo neste movimento não é um aqui ou lá, presença ou ausência, mas o entre, o intervalo e a diferença como diferança e movimento de diferir.

É necessário que um intervalo o separe do que não é ele [presente] mesmo para que ele seja ele mesmo, mas esse intervalo que o constitui em presente deve, no mesmo lance, dividir o presente em si mesmo, cindindo assim, como o presente, tudo o que a partir dele se pode pensar, ou seja, todo o ente, na nossa língua metafísica, particularmente a substância e o sujeito. ${ }^{449}$

Sobre o intervalo, o entre, Derrida em outra passagem esclarece: "o intermediário é o meio e é a mediação, o termo médio entre a ausência total e a plenitude absoluta da presença. [...] E o suplemento sustenta aqui o meio entre a ausência e a presença." ${ }^{450} \mathrm{O}$ suplemento é o que diz respeito à adição, ao acréscimo, à substituição e também à metáfora. É outro nome da diferança ${ }^{451}$. Adiciona na promessa de um gozo, de um encontro consigo mesmo, na presença a si prometida, como um suplemento que virá "preencher" (algo que parece faltar), acrescentar, dar plenitude, substituir, numa miragem, que ao adicionar transborda e se apaga. Não apaga a si mesmo, pois não há si mesmo. Princípio de identidade, sempre em se identificando, jogo de substituição, suplementação, metaforização, auto afeção. Derrida deixa claro na passagem a seguir, a relação entre suplemento e intermediário, apontando ao mesmo tempo a imediatez, talvez de uma intuição, ou de um salto (no abismo da diferença entre ser e ente) como algo derivado, uma vez que a cadeia de suplementos, os intermediários, já se dão num rastro sem origem. A imediatez e a falta de mediação descrita por Heidegger no salto do abismo da diferença ou a escuta do apelo no ser intimado sem mediação que rompe com o ouvir impessoal iriam, talvez, em direção oposta ao que Derrida está colocando aqui. Justamente por haver mediações, heranças, efeitos, rastros é que a presença, o ser, a substância, o sujeito, a consciência, o eu estão sempre aí. Seria por que, de algum modo, nos remetemos a estes elementos que eles remetem e produzem efeitos tais e tais e estão aí. E não, o contrário, estariam aí porque teriam encontrado um lugar estável e seguro a si, uma unidade consigo mesmo. Talvez agora, fique mais claro esta passagem de Derrida: "é necessário que um

\footnotetext{
${ }^{448}$ Derrida, Gramatologia, 2004, p.73

${ }^{449}$ Derrida, A Diferença In. Margens da filosofia, 1991, p.45 (Grifado nosso)

${ }^{450}$ Derrida, Gramatologia, 2004, p.192

${ }^{451}$ Derrida, Gramatologia, 2004, p.184
} 
intervalo o separe do que não é ele [presente, eu, consciência, sujeito, ser...] mesmo para que ele seja ele mesmo." ${ }^{452}$ Esta herança que endereça, remete, possui efeitos, rastros diz respeito também ao jogo de substituições, suplementos. Uma vez que nada é em sua unidade consigo mesma, mas suplementaridade, jogo de transbordamento e apagamento, se remetendo, auto remetendo, alargando e substituindo o que já não era.

Através desta sequência de suplementos anuncia-se uma necessidade: a de um encadeamento infinito, multiplicando inelutavelmente as mediações suplementares que produzem o sentido disto mesmo que elas diferem: a miragem da coisa mesma, da presença imediata, da percepção originária [da unidade do eu ou da consciência, por exemplo]. A imediatez derivada. Tudo começa pelo intermediário, eis o que é "inconcebível para a razão". ${ }^{453}$

A respeito da relação desta cadeia de suplementos com os discursos que carregam consigo privilégios e consequentemente exclusões, Derrida nos descreve na seguinte passagem:

A metafísica consiste desde então em excluir a não-presença ao determinar o suplemento como exterioridade simples, como pura adição ou pura ausência. É no interior da estrutura da suplementariedade que se opera o trabalho de exclusão. O paradoxo é anular-se a adição ao considerá-la uma pura adição. O que se acrescenta não é nada, pois se acrescenta a uma presença plena a que é exterior. A fala vem acrescentar-se à presença intuitiva (do ente, da essência, do eidos, da ousia etc.); a escritura vem acrescentar-se à fala viva e presente a si; a masturbação vem acrescentar-se à experiência sexual dita normal; a cultura vem acrescentar-se à natureza, o mal à inocência, a história à origem etc. ${ }^{454}$

Não é por que não há o significado, nem a verdade, este lugar tranquilo, estável e originário que não devemos nada fazer. Veremos ao longo do trabalho que é justamente partindo deste lugar de não neutralidade das leituras e escrituras que devemos começar. Começar da onde estamos, de nossos próprios desdobramentos, heranças, rastros. Derrida mesmo nos diz: “é preciso começar de onde quer que estejamos e o pensamento do rastro, que não pode não considerar o faro, já nos ensinou que seria impossível justificar absolutamente um ponto de partida. De onde quer que estejamos: já num texto em que acreditamos estar."455 Não é que discursos de verdade não surgirão mais, não é isso tampouco que Derrida estaria pensando. Há discursos que se prometem em verdade de, e surgem para tentar desdizer, transgredir, romper com o que foi dito. Este é o próprio

\footnotetext{
${ }^{452}$ Derrida, A Diferença In. Margens da filosofia, 1991, p.45

${ }^{453}$ Derrida, Gramatologia, 2004, p.192-193 (Diálogo nesta parte da obra se dá com Rousseau)

${ }^{454}$ Derrida, Gramatologia, 2004, p.203-204

${ }^{455}$ Derrida, Gramatologia, 2004, p.199
} 
movimento identitário e também da suplementariedade. E por isso, Derrida nos descreve "não há ética sem presença do outro mas, também e por conseguinte, sem ausência, dissimulação, desvio, diferança, escritura." ${ }^{456}$ Em prol de discursos do Bem, do melhor, do justo, do correto, da Verdade, quantos discursos não surgem, quantas atrocidades já não foram feitas. Derrida nos diz que a arquiescritura seria justamente essa origem da moralidade e da imoralidade, abertura não-ética da ética ${ }^{457}$, a possibilidade de uma ética pensando esta abertura violenta. Ele nos relata de maneira muito interessante num diálogo com Lévi-Strauss ${ }^{458}$ que mostra como a violência não surge de um só golpe para desnudar uma inocência original, mas que estaria em toda a escritura, em todo texto, em todo ato. Uma primeira violência apareceria nomeando, classificando, inscrevendo uma diferença. Uma segunda violência viria reformar, transgredir, reparar, apagando o nome que se dizia próprio. Uma terceira violência poderia surgir, revelando a violência originária que desmamou o próprio de sua propriedade, desnudando a não identidade, a classificação como desnaturação do próprio. Derrida descreve estas três violências num diálogo sobre moralidade com Lévi-Strauss, mas sem dúvida, podemos pensá-lo abrangendo a relação com o outro, uma vez que em qualquer relação a violência está inscrita, neste movimento de nomear violentamente e desmamar o próprio, o nome, revelando o próprio movimento como violento. Movimento de diferança desde já desmamado, violento, de uma mãe que tem outra mãe, esta outra, por sua vez, outra, não haveria como aceder ao leite puro materno (do próprio).

Derrida tem um longo trabalho em dialogar com a tradição da metafísica, mostrando justamente este movimento que transborda e se apaga numa autoafeção de diversas escrituras. Sempre buscando tranquilizar-se, e na busca transborda e se apaga. O autor nos mostra assim, o gesto metafísico de querer se tranquilizar, estabilizar, num discurso de verdade, origem, essência, em praças fortes... Com o pensamento de Heidegger, Derrida também acentua este gesto e, nesse sentido ele nos descreve:

o pensamento de Heidegger [...] reinstalaria a instância do logos e da verdade do ser como primum signatum: significado, num certo sentido, "transcendental" [...] implicado por todas as categorias ou por todas as significações determinadas, por todo léxico e por toda sintaxe, e portanto por todo significante linguístico, não se

\footnotetext{
${ }^{456}$ Derrida, Gramatologia, 2004, p.171

${ }^{457}$ Derrida, Gramatologia, 2004, p.171

${ }^{458}$ Derrida, Gramatologia, 2004, p.139
} 
confundindo simplesmente com nenhum deles, deixando-se pré-compreender através de cada um deles, permanecendo irredutível a todas as determinações epocais que - contudo - ele possibilita, abrindo assim a história do logos e não sendo ele próprio senão pelo logos: isto é, não sendo nada antes do logos e fora do logos. O logos do ser, "o pensamento, dócil à Voz do Ser" é o primeiro e último recurso do signo, da diferença entre o signans e o signatum. É preciso um significado transcendental, para que a diferença entre significado e significante seja, em algum lugar, absoluta e irredutível. ${ }^{459}$

Como vemos nessa passagem, Derrida aponta como o pensamento do ser em Heidegger é também manifesto na voz que se ouve, e que se ouvindo se aproxima de si. Esta aproximação acaba por apagar o significante, numa autoafeção pura, condição também da ideia de verdade ${ }^{460}$. Se por um lado, o pensamento de Heidegger, parece não tomar nada fora de si, no mundo, ou em qualquer outro lugar, ou seja, ele não toma um significante acessório, mas se mantém numa auto-afeção, num dentro de si, como experiência do significado, do elemento da idealidade ou da universalidade. Na clausura desta experiência a palavra seria a unidade elementar "do significado e da voz - e ao mesmo tempo como experiência do "ser"." 461 A palavra - ser - asseguraria a possibilidade do ser-palavra a todas as outras palavras (Cf. Introdução à metafísica) e seria précompreendida em toda linguagem (Cf. SZ e Cf. Zollikon) permitindo a abertura ao sentido de ser em geral. Por outro, segundo Derrida, o sentido do ser em Heidegger não se reduziria ao significado nem a palavra ser, ele seria aquilo que se une, mas não se reduz a palavra ser, não estando fora da linguagem, mas possibilitando a palavra em geral, ele, tampouco se reduziria a um "primeiro transcendental" no sentido kantiano, escolástico ou husserliano ${ }^{462}$. Heidegger estaria ao mesmo tempo compreendido e transgredido da metafísica da presença $^{463}$. Nesse sentido, "o desprendimento do ser como "transcendendo" as categorias do ente, a abertura da ontologia fundamental são apenas momentos necessários mas provisórios." ${ }^{464} \mathrm{O}$ autor nos descreve então que o retiro do ser, sua dissimulação faria da história uma história do ser, produzindo-se como logos e marcada como diferença entre ser e ente. Isso indicaria que nada escaparia ao movimento do significante, e em última instância a diferença entre

\footnotetext{
${ }^{459}$ Derrida, Gramatologia, 2004, p.24

${ }^{460}$ Derrida, Gramatologia, 2004, p.25

${ }^{461}$ Derrida, Gramatologia, 2004, p.25

${ }^{462}$ Derrida, Gramatologia, 2004, p.27

${ }^{463}$ Derrida, Gramatologia, 2004, p.27

${ }^{464}$ Derrida, Gramatologia, 2004, p.27
} 
significado e significante como não sendo nada ${ }^{465}$. Derrida aponta, dessa forma, que Heidegger já teria mostrado que o ser não é um significado primeiro em Introdução à metafísica, e a rasura/risco/cruz em Zur Seinsfrage ${ }^{466}$, na palavra ser também denunciariam a transgressão do pensamento heideggeriano com relação a si mesmo. Mostrando que apesar de inscrito nesta metafísica da presença e no logocentrismo, o pensamento de Heidegger transbordaria a ele mesmo, rasurandose, apagando-se. O sentido de ser seria então um rastro significante determinado pela diferença (ôntico-ontológica) como diferança ${ }^{467}$ (différance) e produção do diferir. A passagem pela determinação riscada é uma necessidade, Derrida nos adverte a necessidade de passarmos pela questão do ser no pensamento de Heidegger ${ }^{468}$. Aponta que "esta rasura [a cruz na palavra ser] é a última [também primeira] escritura de uma época. Sob seus traços apaga-se, conservando-se legível, a uma presença de um significado transcendental. ${ }^{\text {469 }}$ Derrida parece ler Heidegger nos mostrando a necessidade de passar pela questão do ser e sua rasura, da mesma forma com relação a diferença ontico-ontológica ${ }^{470}$ para pensarmos a diferança. Nas palavras dele,

A diferança sem mais seria mais "originária", mas não se poderia mais denominála "origem" nem "fundamento", pertencendo estas noções essencialmente à história da onto-teologia, isto é, ao sistema funcionando como apagamento da diferença. Esta só pode, contudo, ser pensada na sua maior proximidade sob uma condição: que se comece determinando-a como diferença ôntico-ontológica, antes de riscar esta determinação. ${ }^{471}$

\footnotetext{
${ }^{465}$ Derrida, Gramatologia, 2004, p.27-28

${ }^{466}$ Esta rasura/cruz acenaria, segundo Heidegger, para as quatro áreas da quaternidade e de sua reunião no ponto de intersecção. Veja Heidegger, The question of Being, 1956/1958, p.83. "A passagem a seguir nos esclarece um pouco este traçado na palavra ser. "Em seu trabalho Sobre a Questão do ser, Heidegger tentara chocar o pensamento representativo cruzando com dois traços a palavra "ser". Recurso artificial para eliminar a possibilidade de objetivação do ser. O cruzamento que incide no centro do ser desfaz as possibilidades de presentificação, porque esfuma o esquema lógico. Mas o traçado cruciforme que acontece revela o acontecimento súbito e constante do ser como possibilidade da emergência do mundo. As pontas do traçado são o desdobramento quaternário das quatro regiões em que acontece o ser e a irradiação do ser em que acontece o encontro dos mortais e dos deuses, da terra e do céu. Assim se instaura originariamente o mundo como acontecimento e lugar originário." Stein, E. Introdução ao pensamento de Martin Heidegger, 2011, p.156. Não vamos nos aprofundar nestas quatro áreas e no que Heidegger acena com esta cruz na palavra ser. Mas nos concentrar na leitura de Derrida onde esta cruz apontaria para uma transbordamento apagamento, um rastro inscrito no próprio pensamento de Heidegger. Veja também Dastur, Heidegger, Derrida et la question de la différence, In. Derrida, la tradition de la philosophie, 2008, p.94

${ }_{467}$ Derrida, Gramatologia, 2004, p.29

${ }^{468}$ Derrida, Gramatologia, 2004, p.28

${ }^{469}$ Derrida, Gramatologia, 2004, p.29

${ }^{470}$ Vamos ver aos poucos em que medida Derrida, apesar de considerar necessário a passagem por Heidegger, ele se diferencia da diferença ontológica.

${ }^{471}$ Derrida, Gramatologia, 2004, p.29
} 
Derrida aponta a necessidade de passarmos pela diferença ônticoontológica, pela questão do ser, para pensarmos a própria diferança, visto que não há fora, não há primeiro nem último, é a partir do rastro "de algo de algo"... que algo pode ser dito, falado, pensado, enviado, encaminhado. Falar da diferança é de algum modo falar também da diferença ôntico-ontológica e Derrida deixa isso claro, uma vez que

os movimentos de desconstrução não solicitam as estruturas do fora. [Mas] só são possíveis e eficazes, só ajustam seus golpes se habitam estas estruturas. [...] operando necessariamente do interior, emprestando da estrutura antiga todos os recursos estratégicos e econômicos da subversão, emprestando-os estruturalmente, isto é, sem poder isolar seus elementos e seus átomos, o empreendimento de desconstrução é sempre, de um certo modo, arrebatado pelo seu próprio trabalho. ${ }^{472}$

A desconstrução como diferança, para Derrida, não viria de fora dizer algo mais verdadeiro, mais radical, não seria algo fundamental que possui uma origem, pois não pertence à história da metafísica, mas marcaria, talvez, o movimento da própria origem apagada. Derrida segue o pensamento heideggeriano em muitas de suas obras. Sem dúvida Heidegger foi um autor de grande peso para a metafísica e para o pensamento derridiano. O que Derrida tenta nos mostrar é que de algum modo, o autor alemão continuaria preso em discursos acerca da verdade, de uma essência, de uma origem, de um logos e com isso, na metafísica da presença, como vimos e veremos mais adiante. Nesse sentido, desconstruindo, ele busca nos mostrar e questionar os possíveis limites em que o pensamento de Heidegger estaria enredado.

Eu tento ao contrário definir a desconstrução como um pensamento da afirmação [...] é desde uma certa desconstrução, em todo caso esta que me interessa, que podemos colocar, me parece, novas questões à Heidegger, decifrar seu discurso, situar os riscos políticos e reconhecer por vezes os limites de sua própria desconstrução. ${ }^{473}$

Quando em Gramatologia ${ }^{474}$ o autor nos descreve que sem diferança não haveria desejo de presença, ele mesmo nos diz que este desejo de presença traria consigo a sua própria insaciedade. Se o desejo se saciasse e a presença alcançasse sua plenitude, estaríamos na ordem do divino, da morte ${ }^{475}$, do absoluto e nada mais haveria para ser dito, feito, pensado. "A diferança produz o que proíbe, torna

\footnotetext{
${ }^{472}$ Derrida, Gramatologia, 2004, p.30

${ }^{473}$ Derrida, Heidegger, l'enfer des philosophes In. Point de suspension, (1987/1992), p.198-199

${ }^{474}$ Derrida, Gramatologia, 2004, p.176

475 "O gozo ele-mesmo, sem símbolo nem supletivo, o que nos admitiria (n)a presença pura elamesma, se algo como tal fosse possível, não seria senão um outro nome da morte." (Derrida, Gramatologia, 2004, p.190)
} 
possível aquilo mesmo que torna impossível." ${ }^{476}$ Neste momento o autor nos questiona acerca do pensamento do ser em relação à diferança. Deve a diferança ser compreendida a partir do sentido de ser? Como talvez fosse pensar Heidegger. Ou deve-se pensar o inverso? Ao estar preso na história da metafísica como presença, não estaria o sentido de ser preso a ela? A diferança não só precederia a metafísica como também a transbordaria, transbordando o próprio pensamento do ser. "Este [pensamento do ser] não diz nada senão a metafísica, mesmo que a exceda e a pense como o que é em sua clausura." ${ }^{\text {477 }}$ Como seria, talvez, o caso do pensamento heideggeriano que vai pensar os destinos do ser como clausuras, dissimulações na história do $\operatorname{ser}^{478}$.

Para Derrida, o logocentrismo e a metafísica da presença apontariam para um desejo exigente de um significado, de um final tranquilizante num jogo de remessas. Mas este jogo escritural é a própria ausência de significado transcendental, abalando assim a onto-teologia e a metafísica da presença. $\mathrm{O}$ autor deixa claro que este jogo não é no mundo, como algo que faria parte de uma mundidade do mundo, ou de um sentido de ser em geral. E aqui ele dialoga, claramente com Heidegger, mas antes do jogo no mundo é preciso pensar o jogo do mundo: um jogo escritural, de diferenças. A unidade do som e do sentido, (o ouvir-se) como vimos, marcaria, por exemplo, este fechamento tranquilizante do jogo. E mesmo a épokhe da fenomenologia descobriria uma experiência transcendental que acaba sendo posta fora do jogo ${ }^{479}$. Pressupondo, talvez, certa neutralidade para alcançar as coisas elas mesmas. De modo semelhante, por exemplo, poderíamos pensar o caso da experiência da angústia na analítica existencial, em que o Dasein se apreende a si mesmo na verdade do ser. Ele se conquista e se alcança como ente singular aberto ao ser, responsável e livre para seu poder-ser-no-mundo. Esta abertura ao ser, podendo ser pensada como este lugar originário, e como origem transcendental, o próprio Heidegger concordaria $^{480}$. Derrida nos diz que o transcendental é uma das formas de redução

\footnotetext{
${ }^{476}$ Derrida, Gramatologia, 2004, p.176

${ }^{477}$ Derrida, Gramatologia, 2004, p.176

478 "O desvelamento do ente enquanto tal é, ao mesmo tempo e em si mesmo, a dissimulação do ente em sua totalidade." (Heidegger, Da essência da verdade, 1973, p.341)

${ }^{479}$ Veja Derrida, La phénomenologie et la clôture de la métaphysique. Introduction à la pensée de Husserl. In. Derrida et la phénoménologie, 2000. Veja Também Sebbah, F. "Déconstruire, c'est dire oui". Déconstruction et réduction. In. Derrida et la phénoménologie. 2000.

480 "O estar suspenso do Dasein dentro do nada originado pela angústia escondida é o ultrapassar do ente em sua totalidade: a transcendência.” (Heidegger, Que é metafísica? 1929/1973, p.240)
} 
do rastro. Este não é nem reduzido ao transcendentalismo fenomenológico e nem rompe totalmente com ele. Quase-transcendental. Não há rompimento total. Não há fora texto $^{481}$. Há sempre uma retenção, um resto, um rastro retendo outro, num movimento de diferir que está sempre remetido. E por isso Derrida fala de uma restância. Se não tem origem e tudo se remete, algo sempre restou para ser remetido, articulado, diferenciado e rastreado. Não de modo a podermos rastrear o rastro até sua origem, pois não há origem, mas desejo de origem que é o mesmo que desejo de si, de plenitude, de presença, de um.

O que Derrida chama de texto aponta para um não enclausuramento dado, opondo-se ao livro que será algo fechado em si. Um texto pode sempre ser retrabalhado, têm várias idades, ele se remete sempre a outros. Este texto, por exemplo, se remete à Derrida, mas também a outros autores e à psicologia $\mathrm{e}$ filosofia, Derrida, por sua vez, se remete a diversos autores, textos outros, textos pessoais, empíricos, históricos, profissionais. De modo que, Derrida mesmo pode ser pensado como um texto. Um texto onde suas margens não são claras e não há possibilidade de aceder à metáfora que descreveria sua genealogia. Sua pertencença histórica não é linear, nem causal, uma vez que suas raízes não tocam no solo. Ou seja, não há essência no texto, mas há uma Necessidade de enraizamento $^{482}$, de presença a si, de desejo, promessa (de unidade, de presença...), "que nunca foi dada mas sim sonhada e desde sempre desdobrada, repetida, incapaz de aparecer-se de outro modo senão na sua própria desaparição." 483

A arquiescritura não busca uma experiência transcendental, ela não tem origem, nem busca origem. Na verdade não dá para dizer nem que ela apaga a origem, na medida em que esta não foi nem reconstituída, e por isso ela é rastro, origem de origem. Não podendo ser pensada como lugar originário nem como derivado "na desconstrução da arquia, não se procede a uma eleição." ${ }^{484}$ Ou seja, não se busca um lugar de verdade, um discurso tranquilo para assentar-se. Transformando-se num original e um outro em derivado. Há um desconforto

"O Dasein humano somente pode entrar em relação com o ente se se suspende dentro do nada [na angústia]. O ultrapassar, porém, é a própria metafísica. Nisto reside o fato de que a metafísica pertence à "natureza do homem".” (Heidegger, Que é metafísica? 1929/1973, p.242)

${ }^{481}$ Derrida, Gramatologia, 2004, p.194

${ }^{482}$ Derrida, Gramatologia, 2004, p.126

${ }^{483}$ Derrida, Gramatologia, 2004, p.139

${ }^{484}$ Derrida, Gramatologia, 2004, p.76 
constante neste pensamento. Ele nos mostra que o rastro imprensa (de imprensão) $)^{485}$ e é impresso, inscreve e é inscrito, marca e é marcado, re- marcado, re- impresso, re-inscrito, re-pensado no -re-, na volta e na repetição no rastro do rastro. Re-pensar o humano. Nesse sentido, Derrida mostra que esta arquiescritura se mostra como um entre, um intervalo ou um espaçamento ${ }^{486}$ que marcaria um tempo morto ativo.

Deve-se reconhecer que é na zona específica desta imprensão e deste rastro, na temporalidade de um vivido que não é nem no mundo nem num "outro mundo", que não é mais sonoro que luminoso, não mais no tempo que no espaço, que as diferenças aparecem entre os elementos ou, melhor, produzem-nos, fazem-nos surgir como tais e constituem textos, cadeias e sistemas de rastros. Estas cadeias e estes sistemas podem-se desenhar somente no tecido deste rastro ou imprensão. A diferença inaudita entre o aparecendo e o aparecer (entre o "mundo" e o "vivido") é a condição de todas as outras diferenças, de todos os outros rastros, e ela já é um rastro. [...] $O$ rastro é verdadeiramente a origem absoluta do sentido em geral. $\mathrm{O}$ que vem afirmar mais uma vez, que não há origem absoluta do sentido em geral. O rastro é a diferança que abre o aparecer e a significação. ${ }^{487}$

\section{2}

\section{Diferença ontológica em Heidegger e Différance em Derrida}

Derrida nos chama a atenção em algumas passagens, da necessidade de se passar pela diferença ontológica para se compreender a diferança (Cf. A Diferença p.41 e p.55-56, Gramatologia p.24-30). É necessário que nos demoremos, nem deixar de passar por ela (diferença ontológica), nem romper com ela, nem afirmála incessantemente. Mas, talvez, desequilibrando-a, alargando-a, marcando no seu interior sua margem, seu limite e passagem, ou seja, sua desconstrução. Uma vez que seria a dominação do ente, a ente(i)dade, a determinação do ser como

\footnotetext{
485 “O termo francês empreinte tem o sentido de marca por sulcos em baixo-relevo, deixadas por um corpo que é pressionado sobre uma superfície (imprensado). Ou seja, imprensão deixada por uma prensa: imprensão." Miriam Chnaiderman e Renato Janine Ribeiro In. Derrida, Gramatologia, 2004, p.76 [nota do tradutor]

${ }^{486} \mathrm{O}$ espaçamento (pausa, branco, pontuação, intervalo em geral etc) que constitui a origem da significação. Para Derrida, este espaçamento (articulação do espaço e do tempo, o vir-a-ser-espaço e o vir-a-ser-tempo seria sempre o não-percebido, o não-presente e o não-consciente. "A arquiescritura como espaçamento não pode-se dar como tal [uma vez que ultrapassamos o limite da fenomenologia], na experiência fenomenológica de uma presença. Ela marca o tempo morto na presença do presente vivo, na forma geral de toda presença. O tempo morto age.” Não é possível uma fenomenologia da escritura. Derrida, Gramatologia, 2004, p.83 "O espaçamento como escritura é o vir-a-ser-ausente e o vir-a-ser-inconsciente do sujeito. Pelo movimento de sua deriva, a emancipação do signo retro-constitui, o desejo de presença. [...] Como relação do sujeito à sua morte, este devir [à deriva] é a própria constituição da subjetividade." Derrida, Gramatologia, 2004, p.84 (Grifado nosso)

${ }^{487}$ Derrida, Gramatologia, 2004, p.79-80
} 
presença que a diferança viria solicitar/abalar/tremer ${ }^{488}$. E que semelhante gesto já teria sido posto por Heidegger com a diferença entre ser e ente (ontológica) com relação, por exemplo às ciências naturais e humanas, como vimos. Já em Ser e tempo o autor alemão viria pensar a destruição da metafísica da presença, o ser como presença. Será que a diferança se ajustaria então a diferença ônticoontológica e seu movimento epocal? Nos chamando a atenção para a complexidade de tal resposta, característica de Derrida, ele nos responde com uma pergunta: "o pensamento do sentido ou da verdade do ser, a determinação da diferança em diferença ôntico-ontológica, a diferença pensada no horizonte da questão do ser, não será isto ainda um efeito intrametafísico da diferança?"489 Não seria esta diferença (ser e ente) e seu desdobramento historial e epocal, a marca da diferança neste desdobramento? "O desdobramento da diferança talvez não seja apenas a verdade do ser e da epocalidade do ser." ${ }^{490}$ Talvez seria uma época do diapherein. Não poderíamos continuar chamando de época, "uma vez que o conceito de epocalidade pertence ao interior da história como história do ser." ${ }^{491}$ Talvez haja aqui, para nossa compreensão e hipótese, um argumento central em Derrida, ele nos diz: “o ser jamais teve 'sentido', jamais foi pensado ou dito senão dissimulando-se no ente, a diferança, de uma certa e muito estranha maneira, (é) mais 'velha' do que a diferença ontológica ou do que a verdade do ser." ${ }^{492} \mathrm{O}$ que parece também estar em jogo neste argumento, é justamente a determinação do outro do ser como ente, enclausurados nos limites desta diferença, eles responderiam pela época e pela história do ser, pelo mundo como época e verdade do ser. Enquanto a diferança não é, não comanda, não tem autoridade, não se anuncia por maiúscula, não tem reino, mas subverte e ameaça o próprio desejo de reinado. Não tem idade, pois não tem começo nem fim, sua "velhice" apontaria para o jogo do rastro, origem de origem, origem apagada, transbordada. Ela suportaria e daria (ultrapassando, alargando) limites às oposições, aos duplos, às cumplicidades, por exemplo, entre ser e ente. Apontando, assim, os privilégios dos discursos e com isso as exclusões em jogo.

\footnotetext{
${ }^{488}$ Derrida chama a atenção para o verbo sollicitare em latin antigo que significaria abalar como um todo, fazer tremer na totalidade. (Derrida, A Diferença, In. Margens da filosofia, 1991, p.55)

${ }^{489}$ Derrida, A Diferença In. Margens da filosofia, 1991, p.55-56 (Grifado nosso)

${ }^{490}$ Derrida, A Diferença In. Margens da filosofia, 1991, p.56 (Grifado nosso)

${ }^{491}$ Derrida, A Diferença In. Margens da filosofia, 1991, p.56

492 Derrida, A Diferença In. Margens da filosofia, 1991, p.56 (Grifado nosso)
} 
Num diálogo com o texto heideggeriano $O$ dito de Anaximandro (1946), Derrida nos descreve que Heidegger nos diria que a diferença entre ser e ente (ôntico-ontológica) teria desaparecido sem deixar rastro $(S p u r)^{493}$. O que parece acontecer é que "sua própria perda [da diferença ôntico-ontológica] é resguardada, guardada, considerada [regardée], retardada. Num texto. Sob a forma da presença. Da propriedade. Que é, ela própria, um efeito de escritura." ${ }^{, 494}$ Derrida nos diz que o autor alemão, parece ainda manter, guardar, resguardar, esta diferença (ontológica) como um lugar estável, talvez, um ponto de apoio, e que responderia e se associaria ao Dasein humano, à verdade e ao destino historial. A passagem a seguir, nos esclarece um pouco mais. Heidegger escreve:

Mas o esquecimento da diferença com que se inicia o destino do ser, para se consumar nele, tampouco é um defeito, mas o acontecimento mais rico e vasto em que a história ocidental do mundo chega a sua resolução. É o acontecimento da metafísica. O que agora é, se encontra sob a sombra do destino do esquecimento do ser já previamente ocorrido. ${ }^{495}$

Como vimos, o que Derrida parece querer chamar a atenção, é que Heidegger guarda esta perda, este esquecimento como algo próprio e presente, onde tudo se volta e se reenvia a ela. Dela se destina e nela se marca uma origem. “A presença então, longe de ser, como se acredita comumente, o que o signo significa, aquilo para que reenvia um rastro, a presença é então rastro do rastro, o rastro do apagamento do rastro." ${ }^{496} \mathrm{O}$ alargamento derridiano vai em direção a pensar o presente como "signo do signo, rastro do rastro. [...] estrutura de reenvio

\footnotetext{
${ }^{493}$ Heidegger O dito de Anaximandro In. Caminhos da floresta, 2002, p.430 "O esquecimento do ser pertence ao estar-a-ser do ser - que aquele mesmo esquecimento esconde. $\mathrm{O}$ esquecimento pertence tão essencialmente ao destino do ser que a madrugada deste destino começa como desvelamento do que está presente no seu estar-presente. Quer dizer: a história do ser começa com o esquecimento do ser, começa com o ser a reter em si o seu estar-a-ser, a diferença em relação ao ente. A diferença desaparece. Permanece esquecida. Só as coisas que são diferenciadas, o que está presente e o estar-presente, é que se desvelam - mas não enquanto coisas diferenciadas. Em vez disso, também o vestígio [rastro] inicial da diferença é apagado, uma vez que o estar-presente aparece como algo que está presente e encontra a sua origem naquilo que, de entre o que está presente, tem um carácter mais elevado."

"El olvido del ser forma parte de la esencia del ser velada por el propio olvido. Forma parte tan esencial del destino del ser, que la aurora de este destino comienza como desvelamiento de lo presente en su presencia. Esto quiere decir que la historia del ser comienza con el olvido del ser, desde el momento en que el ser se repliega con su esencia: la diferencia respecto a lo ente. Cae la diferencia. Queda olvidada. Lo que se desencubre es lo diferente, lo presente y la presencia, pero no en tanto que eso diferente. Por el contrario, se borra hasta la primera huella [Rastro - Spur] de diferencia, desde el momento en que la presencia se manifiesta como lo presente y encuentra su origen en un supremo presente." Heidegger La sentencia de Anaximandro In. Caminos de bosque, 2010, p.271

494 Derrida, A Diferença In. Margens da filosofia, 1991, p.59

495 Heidegger, La sentencia de Anaximandro In. Caminos de bosque, 2010, p.271

496 Derrida, Ousia gramme In. Margens da filosofia, 1991, p.104
} 
generalizado. É rastro e rastro do apagamento do rastro." ${ }^{497}$ Não haveria assim origem nem dissimulação desta origem, muito menos próprio e impróprio, nem mesmo poderíamos dizer: presença. Derrida nos chama a atenção para a seguinte passagem de Heidegger

Contudo, a diferença entre ser e ente só pode ser experimentada como uma diferença esquecida se ela já tiver sido desvelada com o estar-presente do que está presente e se, assim, já tiver cunhado um vestígio [rastro] [so eine spur geprägt hat] que permaneça preservado na linguagem em que o ser vem a ser expresso. ${ }^{49}$

Derrida pergunta por que continuar pensando a diferença como ontológica? Até onde o esquecimento do ser como rastro ${ }^{499}$ poderia ser pensado? Será que não haveria um apelo para uma língua (dis)tinta do ser? ${ }^{500}$ Enquanto nomearmos a diferença ela estará inscrita na metafísica. Sendo inominável não haveria nome a dar a ela, nem ser, nem essência, "nem mesmo o de 'diferança",501. Mais uma vez, vale acentuar que nela, no que chamamos de diferança, o que está em jogo não é um reinado, uma verdade, uma essência, mas o jogo, as substituições, os deslocamentos sem cessar, efeitos sem começo nem fim, nem presença, nem ausência. Derrida nos mostra que não há palavra única, não há mestre, assim ele nos questiona acerca dos privilégios e os próprios da identidade e das identificações que nos são próximas-próprias. Por não haver mestre não se deve pensar com nostalgia, nem com o que ele chamou de esperança heideggeriana relacionando-a com aquilo que a $O$ dito de Anaximandro lhe pareceu reter da

\footnotetext{
${ }^{497}$ Derrida, A Diferença In. Margens da filosofia, 1991, p.58

${ }^{498} \mathrm{O}$ dito de Anaximandro In. Caminhos da floresta, 2002, p.431 e Heidegger La sentencia de Anaximandro In. Caminos de bosque, 2010, p.271-272 "Pero al haber sido olvidada, la diferencia del ser respecto a lo ente sólo puede ser experimentada cuando ya se desvela en la presencia de lo presente y, de este modo, imprime una huella [rastro] [so eine spur geprägt hat] que permanece guardada en el lenguaje al que llega el ser."

499 "A tradução de $T O ́$ XP $€ W V$ por "o uso" não surgiu de uma reflexão etimológica e lexical. A escolha da palavra "uso" surge de um precedente traduzir do pensar - o qual procura pensar a diferença no estar-a-ser do ser - em direcção ao início histórico do esquecimento do ser. A palavra "o uso" é ditada ao pensar na experiência do esquecimento do ser. Aquilo que fica realmente por pensar na palavra "o uso" é algo de que TÓ XP€WV, presumivelmente, nomeia um vestígio, um vestígio que, no destino do ser - o qual se desenvolve, na história do mundo, como Metafisica ocidental -, desaparece rapidamente." Heidegger, O dito de Anaximandro In. Caminhos da floresta, 2002, p.435

"La traducción de TÓ XP€WV por «el uso» no ha surgido sólo de una meditación etimológica y léxica. La elección del término uso nace de una traslación anterior del pensar, que intenta pensar la diferencia en la esencia del ser, en el inicio destinal del olvido del ser. La palabra «uso» ha sido dictada al pensar en la experiencia del olvido del ser. Probablemente; TÓ XP€WV nombra un rastro de lo que queda verdaderamente por pensar en el término "uso", rastro que desaparece de inmediato en el destino del ser, el cual se despliega en la historia del mundo como metafísica occidental." (Heidegger, La sentencia de Anaximandro In. Caminos de bosque, 2010, p.274)

${ }^{500}$ Derrida, A Diferença In. Margens da filosofia, 1991, p.60

${ }^{501}$ Derrida, A Diferença In. Margens da filosofia, 1991, p.62
} 
metafísica: "a procura do nome próprio, do nome único."502 O autor nos apresenta a seguinte passagem de Heidegger:

A relação com o presente, desdobrando-se a sua ordem na essência mesma da presença, é única (ist ein einzige). Mantém-se por excelência incomparável a qualquer relação. Ela pertence à unicidade do próprio ser (Sie gehort zur Einzigkeit des seins selbst). A língua deveria, portanto, para nomear aquilo que desdobra no ser (das Wesend des Seins), encontrar uma só palavra, a palavra única (ein einziges, das einzige Wort). É aí que medimos quando é arriscada toda a palavra do pensamento [toda palavra pensante: denkende Wort] que se dirige ao ser (das dem sein zugesprochen wird). Não obstante, o que aqui se arrisca não é qualquer coisa de impossível; porque o ser fala em toda parte e sempre através de toda a língua. ${ }^{503}$

Esta passagem apontaria o que Derrida parece nos mostrar em diversos diálogos com Heidegger, existiria uma aliança da fala e do ser na palavra única, como propriedade e proximidade. Neste sentido, o autor nos diz que justamente aí se inscreve o jogo da diferança, se pondo (sobre) cada um dos membros da seguinte frase: "O ser/fala/em toda a parte e sempre/através/de toda/língua." ${ }^{504} \mathrm{E}$ assim desconstruindo-os, alargando-os, uma vez que nenhum deles se estabiliza na pretensa tranquilidade já descontruída pelo jogo da diferança.

Em outra longa passagem Derrida parece deixar mais claro o que, talvez, pudesse ser alargado, tremido, solicitado em Heidegger. A diferança que, como vimos, também terá seu próprio nome apagado, no(s) texto(s), no(s) texto(s) metafísico(s), de mãos dadas com o rastro, transborda e apaga. No texto heideggeriano, neste movimento de alargamento, Derrida nos mostra que também haveria certo transbordamento. Sepultando os próprios, os nomes-mestres, os privilégios, Derrida treme, solicita e alarga, remetendo o que já sempre foi remetido, desconstruindo o que parecia "praça forte":

\footnotetext{
${ }^{502}$ Derrida, A Diferença In. Margens da filosofia, 1991, p.62

${ }^{503}$ Derrida, A Diferença In. Margens da filosofia, 1991, p.63 (Grifado nosso) "A relação com o presente que reina na própria essência, é única. Permanece por excelência incomparável com qualquer outra relação. Forma parte da unicidade do próprio ser. Assim pois, para nomear o que se faz presente no ser, a língua deveria encontrar uma única palavra, a única. Isto nos permite medir até que ponto é ousada qualquer palavra pensante que apela ao ser. Mas este rico não é nada impossível, pois o ser fala das maneiras mais distintas sempre e em todo lugar, através da língua." La relación con lo presente que reina en la propia esencia de la presencia, es única. Permanece por excelencia incomparable con cualquier otra relación. Forma parte de la unicidad del propio ser. Así pues, para nombrar lo que se hace presente en el ser, la lengua debería encontrar una única palabra, la única. Esto nos permite medir hasta qué punto es osada cualquier palabra pensante que apela al ser. Pero ese riesgo no es nada imposible, pues el ser habla de las maneras más distintas siempre y en todo lugar, a través de toda lengua." (Heidegger La sentencia de Anaximandro In. Caminos de bosque, 2010, p.272) e Heidegger, O dito de Anaximandro In. Caminhos da floresta, 2002, p.432

${ }^{504}$ Derrida, A Diferença In. Margens da filosofia, 1991, p.63
} 
É necessário reconhecer desde então que todas as determinações de semelhante rastro - todos os nomes que lhe damos - pertencem enquanto tais ao texto metafísico que abriga o rastro e não ao próprio rastro. Não há rastro ele mesmo, rastro próprio. Heidegger diz justamente que a diferença não poderia aparecer como tal (Lichtung des Unterschiedes kann deshald auch nicht bedeuten, dass der Unterschied als der Unterschied erscheint) $\mathrm{O}$ rastro desse rastro que (é) a diferença não poderia, sobretudo, aparecer nem ser nomeado como tal, o mesmo é dizer, na sua presença. E o como tal que precisamente e como tal se furta para sempre. De igual modo as determinações que nomeiam a diferença são sempre de ordem metafísica. E não apenas a determinação da diferença entre presença e o presente (Anwesen/Anwesenden), mas também a determinação da diferença entre o ser e o ente, então, talvez, a diferença seja mais velha se o ser, segundo esse esquecimento grego que teria sido a própria forma da sua vinda, jamais quis dizer outra coisa que não o ente do que o próprio ser. Haveria uma diferença mais impensada ainda do que a diferença entre o ser e o ente. Sem dúvida não será mais possível nomeá-la na nossa língua. Para além do ser e do ente, essa diferença diferindo (-se) sem cessar, sulcar-(se)-ia (ela mesma), essa diferança seria o primeiro ou último rastro se ainda se pudesse falar aqui de origem e de fim. ${ }^{505}$

\section{3}

\section{Verdade e ser - próprio e nós: o tema da proximidade em Heidegger}

Veremos a partir do texto de Derrida os fins do homem $^{506}$ realizado para um colóquio em outubro de 1968, intitulado antropologia e filosofia, de que forma o pensamento do próprio do homem estaria inseparável da questão ou da verdade do $\operatorname{ser}^{507}$. Derrida vai apontar para uma relação, talvez, irredutível entre a verdade, $o$ ser e o homem, sempre se recolocando de distintas formas, mas não questionando a própria proximidade em si, o próprio e o próximo dela. Não questionando, assim, sua unidade, nem seus limites. Em que medida, o pensamento do próprio, do próximo a si, poderia ser problemática? Para Derrida, é também através da propriedade e da proximidade que muitos discursos seriam validados, assegurados, transmitidos e identificados. Uma vez que uma pretensa identidade, por exemplo, diria respeito aquilo que não possui distância consigo mesmo, mas

\footnotetext{
${ }^{505}$ Derrida, Ousia e gramme In. Margens da filosofia, p.104-105 (Grifado nosso)

${ }^{506} \mathrm{O}$ texto Os fins do homem busca pensar o que hoje nos autorizaria a considerar como essencialmente antropocêntrico, tudo o que teria, na metafísica, levado a acreditar na possibilidade de delimitar o antropologismo? Em que medida estes limites seriam claros e o que seria esta superação para Heidegger? (Derrida, 1991, p.159) Derrida dialoga neste texto também com Husserl e com Hegel, mas não iremos nos aprofundar aqui neste diálogo.

507 "O que hoje é difícil pensar é um fim do homem que não seja organizado por uma dialética da verdade e da negatividade, um fim do homem que não seja uma teleologia na primeira pessoa do plural." (Derrida, Os fins do homem In. Margens da filosofia, 1991, p.161) Em outra passagem, Derrida acentua: "o pensamento da verdade do ser em nome do qual Heidegger delimita o humanismo e a metafísica, permanece um pensamento do homem." (Derrida, Os fins do homem Margens da filosofia 1991, p.169)
} 
seria da ordem da proximidade a si, da verdade e da propriedade. Ou seja, os discursos partiriam da noção de que o que me é próprio é aquilo que tenho de mais próximo, de mais verdadeiro, aquilo que fala da minha essência como coincidência a si, como relação a si. Ao apontarem uma proximidade, propriedade e, assim, uma verdade, os discursos nela embasados acabam excluindo aqueles que não fariam parte desta pertencença próprio-verdadeiro. De certo modo, é também para estas exclusões que Derrida está nos chamando a atenção. A relação próprio-próximo revela um privilégio que em Heidegger será também ${ }^{508}$ denunciado. Derrida é um autor que pensa aquilo que não podemos alcançar, aquilo que não nos é próximo e que sustenta tantos discursos que preponderam em cenários diversos, inclusive e, principalmente, nos discursos acerca da relação com o que (in)compreendemos por humano. Fica mais clara a posição de Derrida nas passagens a seguir. “[...] o ponto de partida da analítica existencial no Dasein não privilegia somente a relação com si, mas o poder de questionar. ${ }^{509 \text {, }}$

O ponto de partida escolhido, a entidade exemplar para uma 'leitura do sentido do Ser, é o que nós somos, nós, os seres questionantes, nós que, à medida que abrimos à questão do Ser e do ser da entidade que somos, temos relação de presença ou de proximidade, essa relação com si, destituído de tudo que não for Dasein. Mesmo se o Dasein não for o sujeito, esse ponto de partida (também entendido por Heidegger como ontológico-fenomenológico) se mantém análogo, nessa sua 'lógica' ao que ele herda ao tentar desconstruí-lo. ${ }^{510}$

Este discurso do nós homens, questionantes, abertos ao ser, privilegiaria o homem e com isso, uma relação única, humana, com a essência humana, com a origem, com a responsabilidade, a liberdade, a verdade, a ética e os direitos ${ }^{511}$. A resposta a um quem acaba sempre estando reservada ao homem, ao sujeito, por argumentos de proximidade e propriedade a si. Esta relação de propriedade e proximidade com o "homem", do "homem" é mostrada no pensamento de Heidegger, sobretudo, em suas obras Ser e tempo, carta Sobre o humanismo e Seminários de Zollikon, obras estas cuja relação com o humanismo, a antropologia e a psicologia seria, talvez, mais direta. Neste sentido, Derrida nos diz que é justamente a partir de um jogo de proximidade,

proximidade a si e proximidade ao ser que iremos ver constituir-se contra o humanismo e o antropologismo metafísico, uma outra insistência do homem,

\footnotetext{
${ }^{508}$ Apesar de Derrida ter um longo trabalho acerca da metáfora do próximo-próprio, vamos nos ater a como este privilégio apareceria no pensamento de Heidegger.

${ }^{509}$ Derrida, Il faut bien manger ou le calcul du sujet In. Points de suspension. 1992, p.282

${ }^{510}$ Derrida, Il faut bien manger ou le calcul du sujet In. Points de suspension. 1992, p.281-282

${ }^{511}$ Derrida, Il faut bien manger ou le calcul du sujet In. Points de suspension. 1992, p.283
} 
rendendo, superando, suprindo o que ela destrói segundo vias nas quais nos encontramos, das quais dificilmente saímos - talvez - e que permanecem abertas à interrogação. ${ }^{512}$

A proximidade que Derrida nos descreve em Heidegger aparece já em Ser e tempo na compreensão do sentido do ser, que será mostrada como a compreensão do significado, do "é", e reconhecida como um Faktum. O que estaria em jogo neste faktum seria a própria disponibilidade do sentido de ser em cada

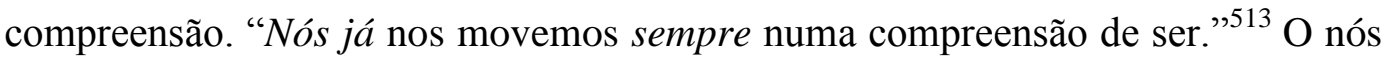
seria justamente o que se abre para tal compreensão e que torna o Faktum reconhecível. Segundo Derrida, este nós, por mais discreto que ele seja, "inscreve a estrutura dita formal da questão do ser no horizonte da metafísica e mais amplamente no meio linguístico indo-europeu à cuja possibilidade está essencialmente ligada a origem metafísica." ${ }^{514}$ Este nós autoriza, sustenta e dá os limites desse Faktum. Derrida nos adverte que tais limites só seriam compreendidos com relação ao seu sentido depois da questão do sentido do ser. Ou seja, o nós autorizaria e daria os limites do Faktum de que se compreende o sentido de ser a partir da compreensão do significado, do "é”. Mas a questão acerca do sentido do ser permanece aberta. $\mathrm{O}$ autor nos adverte ainda para que não simulemos saber o que quer dizer "meio linguístico indo-europeu"515. Derrida é um autor que vai questionar os limites e as delimitações, muitas vezes, tomadas como verdadeiras e pouco questionadas. Gesto este, também muito característico do pensamento heideggeriano. Neste sentido, o que o autor franco-magrebino pode, talvez, nos chamar a atenção seria para certa desconstrução dos limites colocados e não questionados no pensamento de Heidegger em sua relação com o dito humano.

É esta proximidade do nós com a compreensão do ser, esta proximidade a si, que autorizará a exemplaridade e o privilégio do Dasein, o ente questionante que nós mesmos somos. Tal privilégio, num mesmo momento, instaura e exclui aqueles que são privilegiados e os que não são. Aqueles que compreenderiam ser e por isso, seriam exemplares, para a pergunta acerca do sentido de ser em geral, e aqueles que não nos serviriam como exemplo. Haveria uma familiaridade com nós

\footnotetext{
512 Derrida, Os fins do homem, In. Margens da filosofia, 1991, p.164

${ }^{513}$ Derrida, Os fins do homem, In. Margens da filosofia, 1991, p.165

${ }^{514}$ Derrida, Os fins do homem, In. Margens da filosofia, 1991, p.165 (Grifado nosso)

515 Derrida, Os fins do homem, In. Margens da filosofia, 1991, p.165
} 
mesmos que acentua tal proximidade e autoriza a identidade do questionante [Dasein] e do interrogado. "Nós que estamos próximos de nós mesmos, nós nos interrogamos sobre o sentido de ser." ${ }^{, 516}$ Ainda que esta identidade não seja a de uma pessoa, homem, sujeito, mas anterior a todos estes elementos, esta proximidade, esta identidade, ainda falaria de uma unidade (homem - ser verdade) privilegiada em muitos discursos heideggerianos. E um espaço de apropriação desta unidade, seja pela singularidade de um Dasein, cuidadoso, resoluto antecipador, ou como acolhedor e pastor do ser. O que Derrida aponta, é que de algum modo, Heidegger ainda estaria falando de uma essência do homem, ainda que esta essência fosse mais originária que o homem de um suposto humanismo. Sendo esta familiaridade a mais próxima e, portanto, segundo Heidegger, ôntica, ontologicamente estamos mais distantes. Não temos (cotidianamente ao menos) uma proximidade com o ser deste ente que nós somos. Uma vez que o homem se liga primeiramente aos entes em-um-mundo. Como vimos, ele no início e na maioria das vezes se compreende pelo impessoal cotidiano. A escolha dessa exemplaridade está assentada sobre esta proximidade, de nós com nós mesmos e com a questão acerca do sentido de ser, e, neste sentido, ela se daria, segundo Derrida, por um motivo ôntico ${ }^{517}$. A exemplaridade, a escolha do Dasein como exemplar se deve a um motivo ôntico. Uma vez que Heidegger partiria, justamente de uma relação de proximidade absoluta (que Heidegger mesmo afirma ser ôntica - onticamente estaríamos mais próximos), para justificar seu privilégio. O próximo, a compreensão dos sentidos e significados se dá para nós, num primeiro momento, onticamente, ou seja, cotidianamente. Ontologicamente somos distantes. Esta oposição seria inseparável das oposições próprio e impróprio bem como o autêntico e inautêntico em Heidegger ${ }^{518}$.

O que acaba acontecendo é que apesar das críticas feitas ao humanismo e à metafísica, Heidegger não teria questionado a relação irredutível homem-verdadeser, esta é apenas deslocada, a partir de uma "revalorização", Heidegger diria uma radicalização, da própria essência e dignidade do homem. O que está sendo extraviado, esquecido e não assumido é a essência do homem, é ela que deve ser

\footnotetext{
${ }^{516}$ Derrida, Os fins do homem, In. Margens da filosofia, 1991, p.166

${ }^{517}$ Derrida, Os fins do homem, In. Margens da filosofia, 1991, p.168 (nota 14).

${ }^{518}$ Derrida, Os fins do homem, In. Margens da filosofia, 1991, p.168 (nota 14)
} 
reinstaurada para além das determinações metafísicas. Esta reinstauração procura nada mais que a humanização do homem, ou seja, que ele se torne humano e não inumano, que ele busque e esteja em sua essência, digno de sua humanidade. Este movimento, nos pergunta Derrida, não seria o próprio movimento do humanismo? A humanidade do homem repousa em sua essência, dirá Heidegger. E esta só pode ser compreendida quando reivindicada pelo ser. $\mathrm{O}$ que seria reivindicado seria justamente a dignidade da relação ser e homem, em sua proximidade e propriedade.

A própria noção de cuidado como a essência do homem que deve ser apreendida para que o Dasein se aproprie de sua autenticidade, apontaria, talvez, para este movimento de tornar o homem mais humano. O descuido da impropriedade, assim como as determinações metafísicas do homem não seriam falsas, mas não alcançariam a mais alta dignidade humana. O pensamento de Heidegger certamente é contra o humanismo, as determinações substancialistas e redutoras do homem, mas proporia ainda, uma noção da humanitas $^{519}$ do homem mais essencial e própria.

O que Derrida procura nos mostrar é que o pensamento de Heidegger estaria dominado pelo que ele chama de metáfora da proximidade, associando à proximidade do ser, valores como os de vizinhança, abrigo, casa, guarda, voz, escuta, pátria e como vimos e onde estamos nos debruçando, homem - humano. Todos estes substantivos que estão associados à proximidade, à pertença também associam dignidade, raridade, verdade, plenitude .... algumas passagens nos descrevem tal proximidade. O sacrifício preparado pela angústia em que o humano se coloca "em marcha para a defesa do favor do ser [...] defesa da dignidade do ser [...] coragem para o sacrifício, que presume morar na vizinhança do indestrutível [ser]." 520 Em outra passagem, "este agir [do pensar] é provavelmente o mais singelo e, ao mesmo tempo, o mais elevado, porque interessa à relação do ser com o homem."

O ser é o que há de mais próximo, mas se mostra para o homem o mais longínquo, assim como a verdade do ser. "O ser é o próximo do homem e o homem é o próximo do ser [...] eis a verdade que fala, eis a proposição que dá o

\footnotetext{
${ }^{519}$ Cf. Heidegger, Sobre o humanismo 1973 e Heidegger, Seminários de Zollikon, 2010, p.178 [Diálogos com Medard Boss]

${ }_{520}$ Heidegger, Que é Metafísica? [Posfácio],1943/1973, p.248-249

${ }^{521}$ Heidegger, Sobre o humanismo, 1973, p.347
} 
aí $(D a)$ da verdade do ser e a verdade do homem" ${ }^{\text {522 }}$. Sendo o próximo como próprio e vice-versa. Não há na propriedade nenhum valor metafísico de atributos e predicados tais, como o próprio Heidegger nos esclarece, mas ela fala da própria proximidade ser-homem. Tal propriedade aponta para esta inseparabilidade, esta copropriedade: ser e homem. O que Derrida nos lembra, é que na história da metafísica, teria sido também por uma proximidade que "pensou-se o ente (substância ou res) com o seu predicado essencial." ${ }^{523}$ Numa escuta, interrogação e relação na clareira do ser, que só o homem pode estar.

O fim do homem, inscrito no título de sua conferência, estava desde sempre prescrito, com as margens já marcadas no corpo de um texto, o abalo já requerido na estrutura que ele solicita, um transbordamento já se apagando no jogo da diferança. Pode-se, então entender: "o fim do homem é pensamento do ser, o homem é fim do pensamento do ser, o fim do homem é o fim do pensamento do ser" ${ }^{\text {} 24}$. O fim do homem, o fim do próprio, o fim do ser. Há sempre reinscrição. Insistência do homem, superando, suprimindo, radicalizando-se e destruindo. O fim do homem é seu fim, o fim do seu próprio, do mesmo modo, o fim do ser é seu próprio fim, o fim do seu próprio. O jogo do télos e da morte. Derrida sugere a possibilidade de "a partir dessa metaforicidade [da proximidade] e do pensamento da diferença ôntico-ontológica, explicitar uma teoria da metaforicidade em geral $^{525}$.,526

Mantém-se que o ser que não é nada, que não é um ente, não pode ser dito, não pode dizer-se senão na metáfora ôntica. E a escolha desta ou daquela metafórica é necessariamente significante. É na insistência metafórica que se produz então a interpretação do sentido do ser. E se Heidegger desconstruiu radicalmente a autoridade do presente na metafísica, foi para conduzir a pensar a presença do presente. Mas o pensamento dessa presença nada mais faz do que metaforizar, por uma necessidade profunda e à qual se não escapa por uma simples decisão, a linguagem que ele desconstrói. ${ }^{527}$

Derrida, nesta passagem, nos mostra que ao tentar radicalizar o pensamento do presente, desconstruindo-o e mostrando como ele possui um privilégio na

\footnotetext{
${ }^{522}$ Derrida, Os fins do homem, In. Margens da filosofia, 1991, p.174 (Grifado nosso)

${ }^{523}$ Derrida, Os fins do homem, In. Margens da filosofia, 1991, p.174

${ }^{524}$ Derrida, Os fins do homem, In. Margens da filosofia, 1991, p. 175

${ }^{525}$ Voltaremos a falar desta metaforicidade mais a frente. Esta metaforicidade em geral será trabalhada em A Mitologia Branca In. Margens da filosofia, 1991, pp.249-314, que não entraremos neste texto.

${ }^{526}$ Derrida, Os fins do homem, In. Margens da filosofia, 1991, p.171

${ }^{527}$ Derrida, Os fins do homem, In. Margens da filosofia, 1991, p.172. Falaremos mais claramente de metáfora ôntica mais a frente.
} 
metafísica desde Aristóteles à Hegel e à Nietzsche, o que é denunciado é a própria impossibilidade de escapar da linguagem que ele buscou desconstruir. Como vimos, para Derrida, não há fora texto, não há a possibilidade de total rompimento com a tradição. E que o movimento de desconstrução nada mais faz do que transbordar e apagar reinscrevendo-se no texto, na linguagem, na escritura, no movimento (jogo) da diferança.

O que está em jogo neste gesto é o questionamento teleológico que em Heidegger também parece se mostrar entre ser e homem. E sua tentativa de reinscrever a essência do homem numa dignidade mais verdadeira, talvez, mais pura, da humanidade do homem. Denunciando assim, que Heidegger, de algum modo permanece preso e vítima da linguagem que tentou destruir. $\mathrm{Na}$ medida em que o homem e o ser seriam dois "alvos", dois fins, desejados na metafísica. Significados, por vezes, transcendentais, que aparecem privilegiados em diversos discursos. No caso heideggeriano, o discurso excluiria aqueles que não compreenderiam ser, aqueles que não teriam uma relação com ser. Ou ainda, aqueles que não teriam se apreendido como entes cuja relação com ser constitui-se como sua própria essência. Em Heidegger tanto o "humano" (o Dasein) quanto o ser estariam numa relação de proximidade e propriedade, uma vez que o próprio é aquele que apreende sua abertura ao sentido de ser, revelando e excluindo os que não estariam nesta relação. Em que medida tal proximidade não mostraria também certa clausura, já que alguns, algo, algumas.... não participariam desta relação? Em que medida tais privilégios não poderiam comprometer a própria relação com o que (in)compreendemos por humano? Será que podemos pensar esta proximidade-propriedade em outro lugar que não no horizonte indo-europeu (se é que reconhecemos os limites deste horizonte)? No oriente? Nos enfermos? Nos loucos? Nos recém-nascidos? Nos que ainda não sabemos, talvez, se são humanos? Como se reúne nesta palavra humano tudo que chamamos de humano? “Houve, há ainda, na espécie humana, muitos 'sujeitos' que não são reconhecidos como sujeitos [no discurso do direito por exemplo] [...]." ${ }^{, 528}$ Será claro as margens que definem o que compreendemos por sujeito, por humano? Não seria de algum modo, isto também que o gesto derridiano pode nos ajudar a pensar?

\footnotetext{
${ }^{528}$ Derrida, Força de lei: o fundamento místico da autoridade, 2007, p.34
} 


\section{4}

\section{Heidegger: ser, história e mundo em Ser e Tempo}

Nesta parte de nossa pesquisa vamos recorrer ao curso dado por Derrida em 1964-1965 intitulado Heidegger: la question de l'Être et l'Histoire. Este curso vai dialogar, sobretudo, com a obra Ser e tempo, outros textos também serão trazidos e trabalhados por nós aqui, tais como: Introdução à metafísica e carta Sobre o humanismo de Heidegger. Assim poderemos trazer elementos extremamente importantes sobre mundo, história, ser e homem a partir da leitura derridiana.

Vamos iniciar este diálogo no curso de Derrida sobre Heidegger a partir do próprio questionamento derridiano no que diz respeito à ligação entre história $e$ ser. Em que medida este "e" une o ser à história? Derrida nos mostra que o próprio Heidegger teria apontado a impossibilidade de um pensamento histórico escapar da metafísica e da história da ontologia e, neste sentido, a história e o ser, talvez, estivessem sempre ligados, fechados, como uma ligação pressuposta, porém impensada. A questão do ser, como vimos já em Ser e tempo, só poderia se produzir, só poderia acontecer com a destruição da história da ontologia. Visto que esta teria tomado ao longo de sua tradição ser por ente, deste modo, destruir termo heideggeriano - a historia da ontologia seria apontar o esquecimento do ser em detrimento do ente. Toda a nossa história estaria assentada sobre este esquecimento e, por isso, a necessidade de retomar a história da ontologia apontando tal esquecimento, isto é, destruindo-a. Esta destruição não visaria de modo algum excluir negativamente esta tradição, mas ela se mostraria como uma “des-estruturação [...] que é necessária para fazer aparecer as estruturas, os extratos, os sistemas de depósito [da tradição ontológica]." ${ }^{529}$ Depósitos necessários, ônticos, que no entanto, encobrem a questão do ser propriamente dita. Para a retomarmos, seria necessário mostrar tais encobrimentos, tais depósitos, estruturas que serão des-estruturadas, destruídas. Nas palavras de Derrida, fica clara a relação entre ser e história, pois

a questão do ser [...] não tem sentido se ela não questiona a partir do ente e da entidade do ente na totalidade, assim a totalidade de sua história e na totalidade de sua explicitação na filosofia [...]. Como o ser não é o ente, ele não é nada fora do

\footnotetext{
${ }^{529}$ Derrida, Heidegger: la question de l'Être et l'Histoire, 2013, p.34.
} 
ente, ele não é outro ente, ele não é nada onticamente - fora de suas determinações ônticas, então fora de sua totalidade e da totalidade de sua história. ${ }^{530}$

A historicidade do ser e a historicidade da verdade do ser não estariam totalmente presentes em Ser e tempo, visto que a historicidade nesta obra é historicidade do Dasein e não do Sein e serviria como uma fase preliminar na introdução da questão do Ser e da história. Neste ponto, nos descreve Derrida, “o preliminar é talvez mais que o preliminar e não existe entre o Dasein e o Sein [...] relação simples de meio e fim, de caminho de acesso a cada acessível ou de limite a outro limite." 531 Começar pelo Dasein já seria ir muito longe, nos afirma Derrida, pois não é tão claro os limites estabelecidos entre ser e Dasein. Poderíamos dizer que eles caminham em sua maioria juntos nas obras heideggerianas. Sem dúvida esta relação vai se modificando, aos poucos o Dasein vai tomando um papel mais secundário nas obras de Heidegger, mas ele continua em um papel privilegiado em relação aos demais entes. Fica mais clara então a escolha do autor franco-magrebino pela obra Ser e tempo, como fase preliminar e introdutória, não sendo de modo algum a conclusão de sua leitura, mas muito já nos diria da própria relação entre Ser, homem, história e mundo. Relação esta que se mantém imbricada, ainda que de modos distintos, por quase todo o percurso heideggeriano. Como podemos ver em algumas passagens a seguir [algumas já trazidas anteriormente]:

Investigamos a questão [qual é o sentido do ser?] Trata-se de enquadrar a existência Histórica do homem o que implica também nossa própria existência futura, na totalidade da História a nós destinada dentro do poder do Ser a ser descoberto originariamente. ${ }^{532}$

"Nela [questão do Ser] há de se conceber e fundamentar a essencialização do homem segundo a indicação oculta no princípio como o lugar de que carece o Ser para a sua abertura. O homem é a estância (sistência) em si mesma aberta (ex.) Nela o ente in-siste e se põe em obra. Daí dizermos: o ser do homem é, no sentido rigoroso da palavra a 'ex-sistência' (Dasein). É na essencialização da ex-sistência entendida, como tal estância da abertura do Ser, que se deve fundar originariamente a perspectiva para a abertura do Ser." ${ }^{\circledR 533}$

"Se não fosse destinado ser ao Da-sein, também não haveria compreensão do ser." 534

"A história do ser sustenta e determina cada condition e situation humaine."

"O ser é como o destino do pensar. O destino, porém, é em si historial. Sua história já chegou à linguagem, no dizer dos pensadores."

\footnotetext{
${ }^{530}$ Derrida, Heidegger: la question de l'Être et l'Histoire, 2013, p.59

${ }^{531}$ Derrida, Heidegger: la question de l'Être et l'Histoire, 2013, p.76

${ }^{532}$ Heidegger, Introdução à metafísica, 1999, p.68

${ }^{533}$ Heidegger, , Introdução à metafísica,1999, p.226

${ }^{534}$ Heidegger, Seminários de Zollikon, 2001, p.233-234 (Grifado nosso)

${ }^{535}$ Heidegger, Sobre o humanismo 1973, p.347
} 
Derrida vai trabalhar neste curso a noção de metáfora ôntica em Heidegger a partir do contar histórias ${ }^{537}$. Tal expressão fica mais clara quando em Ser e tempo o autor nos fala da necessidade da destruição da história da ontologia que teria nos contado histórias tomando ser por ente ao invés de ir ao encontro do que seria importante: a questão do sentido do Ser. Ainda que Heidegger não tenha pronunciado diretamente a diferença ôntico-ontológica ${ }^{538}$ nesta obra, seria disso que ele falaria implicitamente ao distinguir Gefragte (o ser) e o Befragte (o sentido do ente interrogado) e quando ele aponta a pré-compreensão de ser como o espaço, a abertura na qual ser e Dasein se relacionam, na qual a questão mesma pode ser posta, onde a diferença entre ser e ente se coloca. Desta forma, Derrida nos diz que contar histórias ${ }^{539}$, para Heidegger, seria justamente ignorar a diferença entre ente e ser, seria determinar a origem do ente a partir de outro ente. Para aqueles $\operatorname{raros}^{540}$ que não tem a possibilidade de apreender esta diferença (ente-ser), de aceder

à origem do mundo do ente em seu ser. [...] Contar histórias - no sentido que nós damos agora a esta expressão - é então uma necessidade quando nos endereçamos a todo mundo [...] quando se quer transmitir a questão da origem àqueles que ainda não tem acesso. Necessidade da metáfora ôntica. ${ }^{541}$.

A metáfora ôntica nesta passagem diz respeito a dizer algo não dizendo outro, no caso, não dizer e não contar sobre o pensamento do ser e o que é dito se mantém no campo dos entes, do ôntico, de tudo o que é, e onde nos encontramos na maior parte das vezes. Nos mantemos assim, na metáfora ôntica, no contar

\footnotetext{
${ }^{536}$ Heidegger, Sobre o humanismo 1973, p.372

${ }^{537}$ Referência ao sofista de Platão (242e) no qual não vamos nos aprofundar.

${ }^{538}$ Heidegger, Ser e Tempo, 2012, $\$ 4$

${ }^{539}$ Heidegger, Ser e Tempo,2012, $\$ 2$ p.43 “O primeiro passo filosófico para a compreensão da problemática-do-ser consiste em não 'contar uma história', isto é, em não determinar o ente como ente por sua redução a um outro ente do qual proviria, como se o ser tivesse o caráter de um ente possível."

${ }^{540}$ Derrida nos descreve que do Timeu ao Heidegger este segredo da questão do ser não poderia ser compartilhado com aqueles que não têm acesso, sem arriscar-nos de contar histórias, "nada é menos secreto que este segredo. Nada é melhor compartilhado." (Derrida, Heidegger: la question de l'Être et l'Histoire, 2013, p.72) Lembrando que a linguagem é a casa do Ser e que a questão da linguagem se entrelaça intimamente com a questão do Ser em Heidegger, ele mesmo nos afirma: "pouquíssimos apenas são os que estão em condições de pensarem, em todo o seu alcance, o que há de deficiente e desvirtuado nessa relação da existência humana atual com a linguagem" (Heidegger, Introdução à metafísica, 1999, p.76). "É uma raridade que haja médicos que pensam, que não estão dispostos a dar lugar aos técnicos científicos." Heidegger, Seminários de Zollikon, 2001, p.129. Este segredo, para os raros, os poucos é descrito com mais detalhes, mas nós não vamos nos ater aqui em suas minúcias, ficando ao leitor uma breve explicitação e o esclarecimento do que podemos compreender aqui por metáfora ôntica e sua relação com o segredo.
}

${ }^{541}$ Derrida, Heidegger: la question de l'Être et l'Histoire 2013, p.70 
histórias, no esquecimento do ser, necessidade esta para aqueles que não tem acesso à origem. Quem são os que teriam acesso a esta essência originária? Os raros. Para Derrida, quando Heidegger utiliza as metáforas - o campo ôntico - o que ele teria em mente, na verdade, seria voltar à origem da metáfora ou da metaforicidade, pensá-la antes de qualquer técnica retórica. Questionar o ôntico a partir do ontológico fundamental, questionar o ser tomado como ente. Falar na linguagem comum seria estar na metáfora, ela é o esquecimento do sentido próprio e originário, ela seria "o começo da linguagem cujo pensamento do ser é portanto a origem enterrada [enfouie]." ${ }^{, 542}$ A metáfora não seria de modo algum uma fantasia que em breve desnudaremos e o pensamento do ser nu seria exposto. Derrida nos deixa claro que em Heidegger o pensamento do ser nunca estaria nesta pureza nua. A metáfora acompanha incessantemente sem nunca encontrá-lo, ela cobre a verdade do ser e seria a própria essência da metafísica que nunca seria ultrapassada. Pois o mais fundamental não é o ser nem o ente, mas a diferença serente, a diferença ontológica. Ultrapassá-la seria pôr fim a esta diferença. Heidegger mesmo, de certo modo, nos deixa isso claro em Ser e tempo, quando afirma que a dissimulação da inautenticidade, a cotidianidade mediana é tão importante quanto o desvelar da autenticidade e a decisão resoluta. A dimensão ôntica dos entes seria tão importante quando a do sentido do Ser, (Cf. Heidegger, Introdução à metafísica, 1999, III, p.117-118).

A filosofia como discurso que busca destruir a metáfora, as histórias contadas, só conseguiria com a ajuda de outras metáforas. Derrida sugere que poderíamos, talvez, colocar o pensamento do ser como um gesto de desmetaforização ${ }^{543}$, de modo que o gesto heideggeriano vai em direção à essência da própria metáfora, a origem dela, pensar a metáfora em se metaforizando, o que seria em Heidegger pensar o ente em sua entidade, o ente na totalidade do ser. Esta seria a destruição mesma. Este seria, para Derrida, um alvo heideggeriano, ou seja, pensar a questão do sentido do ser (o ontológico) a partir das determinações dissimuladas do ser (o ôntico). Nas palavras de Heidegger, "o desvelamento do ente enquanto tal é, ao mesmo tempo e em si mesmo, a dissimulação do ente em sua totalidade." ${ }^{544}$ Em outra passagem, ele nos descreve

\footnotetext{
${ }^{542}$ Derrida, Heidegger: la question de l'Être et l'Histoire 2013, p.105

${ }^{543}$ Derrida, Heidegger: la question de l'Être et l'Histoire 2013, p. 278

${ }^{544}$ Heidegger, Da essência da verdade, 1973, p.341
} 
"existem numerosos modos de presença daquilo que se dirige ao Dasein a partir do aberto de seu mundo. [...] O ser só pode ser experienciado em e pela presença de um ente". ${ }^{545}$ Pensar o ser em se entificando, pensar o ser do ente a partir das determinações epocais do ser. Existiria então, a história da tradição, (das metáforas ônticas) e a história da essência da metáfora, da metáfora em se metaforizando, do ser em se entificando, do ser na história dos entes, da presença em se presentificando, da essência em se essencializando. Mais uma vez fica mais clara a relação ser e história em Heidegger. Que não se esgota aqui, mas perpassa o pensamento heideggeriano em diversos pontos.

No final da Deuxième séance, Derrida nos questiona diretamente acerca da necessidade da relação entre ser e Dasein, da necessidade de se passar pela analítica do Dasein para se chegar à questão do ser. Tal necessidade estaria assentada a partir de duas certezas implícitas (ou duas formas de uma mesma certeza) sobre as quais Heidegger teria se apoiado para tratar do caráter histórico da questão do ser. Esta questão vai ao encontro da seguinte: em que medida haveria uma necessidade de passar pela historicidade do Dasein para falar da historicidade do ser? As duas certezas estariam relacionados a um já-sempre que apontaria para uma historicidade, a repetição de uma questão que nunca foi posta, mas que foi já-sempre possível. Como vimos, ser e história sempre estiveram de mãos dadas, mesmo que a questão sobre o sentido de ser estivesse sempre dissimulada (na tradição) e nunca tenha sido posta adequadamente.

A primeira das certezas estaria relacionada à já acessibilidade do ser como um fato. Este já-acessível falaria de um já-sempre acessível, familiar, próximo de nós $^{546}$. Como vimos, a questão do sentido de ser já estaria sempre acessível disponível - numa pré-compreensibilidade do Dasein. Ao compreendermos isso ou aquilo já pré-compreendemos o sentido de ser, o que apontaria para o caráter histórico da própria questão do ser, como aquilo que de algum modo já esteve sempre aí. Neste sentido, uma pré-compreensão do sentido de ser já existiria em todo e qualquer comportamento, ciência, ontologia, história... é um Faktum ${ }^{547}$. “O acesso ao sentido de ser ele mesmo que permitirá em última instância a

\footnotetext{
${ }^{545}$ Heidegger, Seminários de Zollikon, 2001, p.175 (fala de Heidegger taquigrafada por Medard Boss)

${ }^{546}$ Vimos também esta proximidade em seu texto Os fins do homem.

${ }^{547}$ Heidegger, Ser e Tempo, §2
} 
determinação em geral de todo fato em geral." ${ }^{548}$ Em Ser e tempo, a précompreensão do sentido de ser seria apresentada como uma pré-compreensão da significação do ser, do "é"549. Esta afirmação de Heidegger aponta justamente para o modo como nos movemos, de início e na maioria das vezes, ou seja, no modo ôntico (metáfora ôntica): cotidiano, impessoal e decadente. Com o esquecimento do sentido de ser somos guiados pelo "é" de toda questão. O faktum da acessibilidade do sentido de ser fazer parte de todo comportamento do Dasein estaria, segundo Derrida, ligado ao fenômeno da linguagem ${ }^{550}$. Uma vez que, não seria ao acaso que Heidegger teria sugerido que a pré-compreensão do sentido de ser fosse apresentada como pré compreensão da significação de ser, do "é”. A possibilidade da questão do sentido de ser estaria intimamente relacionada à possibilidade da linguagem, que será posteriormente esclarecida pelo próprio Heidegger, "o ser é como o destino do pensar. O destino, porém, é em si historial. Sua história já chegou à linguagem, no dizer dos pensadores." ${ }^{551}$ Nesse sentido, Derrida esclarece "O Faktum de uma linguagem em geral (não importa qual) na qual a significação (Bedeutung) da palavra é (ser) é sempre já précompreendida." ${ }^{552}$ Esta relação: sentido, linguagem e significação de ser só ficará mais clara oito anos depois em sua obra Introdução à metafísica. Nela, vemos que é a partir do verbo Ser que a linguagem seria trazida à sua verdadeira essência. "Sem a compreensão do Ser e sem a palavra ser, todas as palavras desapareceriam. ${ }^{, 553}$ Em outra passagem Derrida esclarece o que ele gostaria de sublinhar nesta primeira certeza a respeito da relação entre história, ser e linguagem:

Isto que eu quero somente sublinhar aqui, é que falando do Faktum da linguagem e de uma linguagem onde a palavra ser é entendida, precisa e incontornável, Heidegger liga a possibilidade de sua questão e então de todo discurso em última instância à possibilidade da história. Pois não há linguagem sem história e não há história sem linguagem. A questão do ser é a questão mesma da história. Ela nasce da história, e ela visa à história. Ela é a absolvição da história ela mesma sobre ela mesma como história do ser. ${ }^{554}$

\footnotetext{
${ }^{548}$ Derrida, Heidegger: la question de l'Être et l'Histoire, 2013, p.80

${ }^{549}$ Cf. Heidegger, Ser e Tempo, 2012, p.41

${ }^{550}$ Derrida, Heidegger: la question de l'Être et l'Histoire, 2013, p.82

${ }^{551}$ Heidegger, Sobre o humanismo 1973, p.372

${ }^{552}$ Derrida, Heidegger: la question de l'Être et l'Histoire, 2013, p.86

${ }_{553}^{5}$ Heidegger, Introdução à metafísica, 1999, p.109

${ }^{554}$ Derrida, Heidegger: la question de l'Être et l'Histoire, 2013, p.83 (Grifado nosso)
} 
O sentido de ser só vai aparecer se o ente vem a ser declarado como aquilo que é em seu ser, ou seja, se o ser é dito ${ }^{555}$. Heidegger nos descreve que o pensar (do ser) sulca a linguagem, sulca de modo quase invisível, destinal e historial a partir do dizer dos pensadores ${ }^{556}$. Em outra passagem, já trazida aqui, ele nos descreve que a

linguagem deve ser pensada aqui como dizer [Sagen], no ente como ente, quer dizer, a linguagem se mostra com referência ao ser. Somente baseado na unidade de ser lançado e compreensão pela linguagem como tradição [Sage] é que o homem é interpelável pelo ente em geral. ${ }^{557}$

Este dizer revelaria uma co-pertença entre o ser e a linguagem, o que não reduz o ser a um fenômeno linguístico, mas faz repensar a própria essência da linguagem à luz do sentido de ser. Esta relação linguagem e ser fica mais clara, como vimos, na obra heideggeriana Sobre o humanismo. Devemos deixar claro que a linguagem em Heidegger não seria mais um caráter do homem, mas o homem passaria a ser determinado a partir da linguagem como linguagem do ser. Tal inversão marcaria no autor alemão, a liberação do ser da determinação ôntica, não tendo mais que contar histórias (metáfora ôntica), como faz a tradição, o ser deixaria, assim, de ser produto do homem ${ }^{558}$. Esta liberação seria justamente o fenômeno histórico originário da liberdade, do deixar ser, deixar o ente ser aquilo que ele é, na verdade do ser. A significação de ser não seria mais prederminada e restrita por uma limitação ôntica ${ }^{559}$. A verdade do ser não dependeria mais da linguagem como característica do homem, não estaria no âmbito antropologista. Só haveria linguagem no esclarecimento do ser, de modo que, o sentido de ser, o homem e a linguagem estariam ligados de uma maneira distinta que deve ser explicitada e esclarecida. A linguagem como abrigo do ser, como casa, passa a ter uma relação com o já-sempre histórico. Isso significa que ao nascer já estou numa casa, numa linguagem, num lugar pronto antes de mim. Este já-pronto seria um aqui originário a partir do qual toda escolha ganharia sentido. Começa a ficar mais claro, então, como Derrida nos apresenta esta tríplice relação ${ }^{560}$ heideggeriana: homem, linguagem, ser.

\footnotetext{
${ }_{555}^{55}$ Derrida, Heidegger: la question de l'Être et l'Histoire, 2013, p.83

${ }_{557}^{556}$ Heidegger, Sobre o humanismo, 1973, p. 372

${ }^{557}$ Heidegger, Seminários de Zollikon, 2001, p.165

${ }^{558}$ Derrida, Heidegger: la question de l'Être et l'Histoire, 2013, p.83

${ }^{559}$ Derrida, Heidegger: la question de l'Être et l'Histoire, 2013, p.108-109

${ }^{560}$ Derrida, Heidegger: la question de l'Être et l'Histoire, 2013, p.101
} 
A primeira certeza, do faktum, da instalação da questão do ser e da précompreensão da significação "é" no elemento da linguagem não estaria completamente exposta em Ser e tempo, mas, talvez, já estivesse implícita ${ }^{561}$. Como vimos, Heidegger mesmo teria afirmado isso em Sobre o humanismo ${ }^{562}$. Esta relação em sua obra Introdução à metafísica já está bem mais exposta, nela vemos que o ser não existe fora da significação de ser, mas não se reduz a ela. A linguagem, o sentido e a significação de ser se mostram numa relação muito mais íntima e clara. O sentido de ser aparece na significação do "é”, quando é dito ${ }^{563}$. O homem também é descrito como o único ente falante cuja essencialização depende o poder da linguagem que abre todo e qualquer ente, inclusive nós mesmos. Sem a linguagem todo ente permaneceria fechado ${ }^{564}$. A fala nesta obra toma uma proporção bem maior não só para o homem, mas também para o Ser. A linguagem passa a estar entrelaçada com a questão do ser, é a partir dela que o ser se essencializa, se destina ${ }^{565}$, ela é a casa do ser e o homem seria o único ente que fala, que compreende ser e que ek-siste. Existência, fala e compreensão passam a ser características privilegiadas do homem, pois dizem respeito à sua relação com o Ser. "Pois dizer e evocar o ente, como tal, inclui em si compreender de antemão o ente, como ente, i. é. o seu ser" ${ }^{, 566}$. Sem o ser, não há fala e não seríamos o que somos: homens. "Ser homem significa ser um ente que fala" ser, sentidos e significados de ser.

A determinação da Essencialização da linguagem já até mesmo a sua simples investigação, rege-se sempre pela pré-compreensão dominante a respeito da essência do ente e da concepção de essência. Ora, essência e ser falam na linguagem. ${ }^{568}$

O Faktum da linguagem [primeira certeza] esboçaria a resposta [da questão: por que a história do ser passa pela história da Dasein?] - com as dificuldades que nós reencontramos. Pois o ser não é, nem se produz, nem aparece, fora da linguagem, ele é certamente história mas ele se produz através (e eu deixo este através com todo seu poder enigmático) de um ente falante, ente falante que põe ou a quem ou por quem ou através de quem a questão do ser precisamente se põe. ${ }^{569}$

\footnotetext{
${ }^{561}$ Derrida, Heidegger: la question de l'Être et l'Histoire, 2013, 119

${ }^{562}$ Heidegger, Sobre o humanismo, 1973, p.349

${ }^{563}$ Cf. Derrida, Heidegger: la question de l'Être et l'Histoire, 2013, 119 e Heidegger, Introdução à metafísica, 1999, p.115

${ }_{564}$ Heidegger, Introdução à metafísica, 1999, p.109

${ }^{565}$ Heidegger, Sobre o humanismo, 1973, p.372

${ }^{566}$ Heidegger, Introdução à metafísica, 1999, p.109

${ }^{567}$ Heidegger, Introdução à metafísica, 1999, p.109

${ }^{568}$ Heidegger, Introdução à metafísica, 1999, p.82

${ }^{569}$ Derrida, Heidegger: la question de l'Être et l'Histoire, 2013, p.123-124
} 
Após este parêntese para descrevermos o peso que a linguagem passa a ganhar nas obras de Heidegger, tanto numa relação com ser quanto com o homem, voltemos a primeira certeza exposta por Derrida, o faktum do Ser jásempre ser compreendido. Haveria em Ser e tempo, uma distinção entre o significado e o sentido da palavra ser. Uma vez que o significado, o "é” seria précompreendido (cotidianamente) em toda e qualquer ciência e ontologia, enquanto o sentido de ser não seria pré-compreendido ${ }^{570}$ e deveria ser explicitado. Esta explicitação, ainda na mesma obra, acontece como veremos a partir do Dasein.

Em Introdução à metafísica Heidegger nos descreve claramente que o

"é" denota, no dizer, uma variedade rica de significações. Sempre dizemos "é" numa dessas significações sem termos expressamente necessidade, seja antes ou depois, de empreendermos uma interpretação particular do "é" ou mesmo de refletirmos sobre o sentido do Ser. ${ }^{571}$

O sentido de ser precisa ser explicitado, ele está como que implícito nas significações, no "é" que compreendemos. E por isso, Heidegger perguntaria, em Ser e tempo, em qual ente este sentido de ser deve ser explicitado, deve ser lido (Abgelesen). O ser sem um ente não faria qualquer sentido, e desta forma, a partir de qual ente podemos ler o sentido de ser? O Dasein é o ente (o texto) a partir do qual o sentido de ser poderia ser explicitado - lido, seria a partir dele que a metáfora seria produzida, a metáfora do sentido ao significado, do ontológico ao ôntico $^{572}$, ainda que implicitamente, podemos dizer, da diferença ônticoontológica.

Se só compreendo ser a partir de um ente, seria o "eu sou" posto em Introdução à metafísica, uma proximidade absoluta de mim mesmo (o ente) com o ser? O que Heidegger quer dizer com cada um de nós ser o mais distante de si mesmo? Segue a passagem em que ele apresenta esta proximidade e esta distância.

Dizemos: "eu sou". Nessa acepção, qualquer um só pode dizer ser de si mesmo: o meu ser. Em que consiste esse meu ser e onde se esconde? Aparentemente dizê-lo é para nós muito fácil, de vez que, de nenhum outro ente, estamos tão perto como do ente que somos nós mesmos. [...] E todavia também aqui vale: ninguém está mais distante de si mesmo do que ele próprio [o ente que somos]. ${ }^{573}$

\footnotetext{
${ }^{570}$ A relação entre sentido, significado e a palavra ser só será posta oito anos depois em Introdução à metafísica (L'Einführung in die Metaphysik). Nós não vamos desenvolver nesta pesquisa esta relação apresentada por Heidegger.

${ }^{571}$ Heidegger, Introdução à metafísica, 1999, p.117

${ }^{572}$ Derrida, Heidegger: la question de l'Être et l'Histoire, 2013, p.126

${ }^{573}$ Heidegger, Introdução à metafísica, 1999, p.96
} 
Segundo Derrida ${ }^{574}$, o que Heidegger teria a dizer nesta passagem estaria relacionado à metáfora da proximidade denunciada aqui como uma identidade a si, uma proximidade absoluta que teria seu sentido na forma do eu sou, do cogito mesmo, e que se esclarece, na verdade, a partir da proximidade ao ser compreensão de ser - uma vez que esta pode anunciar de modo não metafísico o sentido de proximidade em geral - o próximo e o distante. É o sentido de ser que funda a proximidade absoluta do eu sou, o aqui, a presença, o agora, o próximo, o distante e todas as demais proximidades. Mas o sentido de ser nesta proximidade absoluta do eu sou não é explicitado, ele está distante de nós mesmos (o ontológico é o mais distante). Ela - a proximidade absoluta do eu sou - seria, por isso, metafísica e também metafórica, nos diz Derrida. Seria a partir desta determinação do sentido de ser ou da iluminação do ser que se iluminaria toda outra proximidade. Seria falando da proximidade do ser ${ }^{575}$ (Cf. Sobre o humanismo), explicitando o sentido de ser, que destruiríamos a metáfora (o campo ôntico) e pensaríamos o eu sou como metáfora também. Esta proximidade, nos mostra Derrida, será chamada de linguagem em Sobre o humanismo. Como vimos, o sentido de ser só se mostra se o ser é dito, uma vez que, o ser é na linguagem, ela é abrigo do ser. Sem a linguagem não haveria ser nem diferença entre ser e ente ${ }^{576}$. "Linguagem é advento iluminador-velador do próprio ser."577

A passagem da primeira certeza à segunda fica mais clara quando Derrida liga a questão do ser à linguagem e a linguagem à elocução da questão, de modo que quem põe a questão deve ter algum privilégio que deve ser exposto ${ }^{578}$. A proximidade ao ser (explicitada também em os fins do homem) já brevemente anunciada vai ao encontro da segunda certeza descrita por Derrida, em que ele fala da relação inseparável Ser-Dasein, abordando o porquê da historia do ser passar preliminarmente pela história do Dasein. A proximidade descrita aqui estará apoiada sobre duas relações que mostraremos aqui em três: 1) a proximidade da questão do Ser com Dasein, 2) a proximidade de nós com nós mesmos e 3) a proximidade do Da com Da-sein. É claro que todas estas

\footnotetext{
${ }^{574}$ Derrida, Heidegger: la question de l'Être et l'Histoire, 2013, p.94

${ }^{575}$ Em Sobre humanismo - esta proximidade é a linguagem. A linguagem não sendo determinada apenas como caráter do homem, mas é a partir dela que o homem é determinado. Esta inversão liberaria o ser das determinações ônticas, não mais pensá-lo a partir de um ente conhecido - o homem.

${ }^{576}$ Derrida, Heidegger: la question de l'Être et l'Histoire, 2013, p.101

${ }^{577}$ Heidegger, Sobre o humanismo 1973, p.354

${ }^{578}$ Derrida, Heidegger: la question de l'Être et l'Histoire, 2013, p.134-135
} 
proximidades se entrelaçam em diversos pontos, afinal elas fazem relação com o mesmo ente, o Dasein, que somos nós mesmos, entes questionantes, aonde a questão se dá aí $(D a)$. Cada proximidade aqui vai implicar a outra necessariamente.

1) A proximidade da questão do Ser com Dasein - O único gesto que sustentaria a escolha do ente exemplar e seu privilégio com relação a questão sobre o sentido de ser, seria a própria questão, ou seja, é a determinação existencial de questionar ser que faz o Dasein ser exemplar. O Befragte, (o Dasein) é justamente aquele que é marcado pela possibilidade da questão. "O único pressuposto da questão é que ela seja posta" ${ }^{\text {"579 }}$ pelo ente questionante que somos nós mesmos. Segundo Derrida, esta exemplaridade do Dasein não pode ser marcada por mera escolha em Heidegger, mas o que estaria em jogo seria justamente a absoluta proximidade deste ente com a questão. Nada seria mais próximo da questão do que o ente que questiona. Nada viria na questão como um objeto de resposta, mas a questão mesma não cansa de se revelar a si mesma. $\mathrm{O}$ interesse de Heidegger, segundo Derrida, seria se aproximar da questão e não pôr fim a ela respondendo-a.

2) A proximidade de nós com nós mesmos - A proximidade de nós com nós mesmos, o faktum que nós somos ${ }^{580}$, revela um nós indeterminado, uma vez que não sabemos quem somos nós: não somos sujeitos, pessoas, comunidade, sociedade. Então, quem somos? Este nós somos tem em comum apenas a possibilidade de questionar, ou seja, a proximidade com a questão, descrita no parágrafo anterior. "Nós somos quer dizer aqui : nós somos questionantes [...] nós somos próximos de nós mesmos." em Ser e tempo seria o mesmo que pre-compreensão, que existir. "Existir (Existenz) é ser de tal forma que o ser mesmo seja (ou signifique) uma tarefa ou uma questão - em jogo - não apenas agora e depois mas em todos os lugares e sempre." $" 582$ A existência, nosso modo de ser, é questionar o ser, esta relação ao ser, esta abertura onde o ser é questionado, espaço esse de pré-compreensão,

\footnotetext{
${ }^{579}$ Derrida, Heidegger: la question de l'Être et l'Histoire, 2013, p.135

${ }^{580}$ Derrida, Heidegger: la question de l'Être et l'Histoire, 2013, p.136

${ }^{581}$ Derrida, Heidegger: la question de l'Être et l'Histoire, 2013, p.136

${ }^{582}$ Malpas \& Crowell, Heidegger e a tarefa da filosofia: escritos sobre ética e fenomenologia, 2012, p.340
} 
onde o ser e ente se relacionam, onde a metáfora se mostra como diferença entre o sentido de ser e o significado, como diferença ontológica.

3) A proximidade do $D a$ com Da-sein - O $D a$ "seria a única diferença entre um X e a primeira categoria do Dasein." ${ }^{\text {583 }}$, é a partir da onde o ser se produz no ente que nós somos, o Da-sein. O ser se produz aí ( $D a$ ) como questão, ele se dá aí sem que haja uma maior compreensão deste aí. É nele e a partir dele que haveria, segundo Derrida, o movimento passando do ente ao ser do ente, a questão se dá aí, o ser em questão é aí. É justamente quando Derrida nos fala da escolha de Heidegger pelo termo Dasein que aparece mais claramente a proximidade do $D a$ com este ente que nós mesmos somos. A pre-compreensão de ser é justamente a determinação ontológica deste ser que nós mesmo somos, de modo que determinamos um ente em seu ser antes mesmo de termos um conceito explícito $^{584}$ do sentido de ser. Todas as ciências, comportamentos e ontologias pressupõe um sentido implícito de ser, esta pressuposição, como vimos, seria a própria pré-compreensão do Dasein como um privilégio. O Dasein já-sempre compreendeu o sentido de ser, pondo a questão do sentido de ser. "No ser-aí [Dasein], o sentido de ser está já aí, se anuncia na possibilidade da questão a referindo explicitamente."

Derrida nos descreve que esta proximidade em Heidegger falaria do campo ôntico, ou seja, onticamente nós somos próximos de nós mesmos, entes questionantes, onde a questão de ser se dá aí $(D a)$. Por outro lado, somos o mais distante ontologicamente. Este próximo e distante, ôntico-ontológico nos introduziria ao problema do círculo hermenêutico onde poderíamos encontrar o problema da historicidade do Dasein $^{586}$. Tal círculo, como Heidegger nos deixa claro e Derrida reafirma, não faz parte de algo que nós devêssemos nos livrar como um círculo lógico vicioso ${ }^{587}$, mas é a própria estrutura na qual nós já estamos, somos e nos movemos. Este círculo falaria justamente do espaço préontologico que não é nem o não-sentido de ser (implícito) nem a explicitação do sentido de ser, não é nem o próximo (ôntico), nem o distante (ontológico). Mas falaria de um $D a$ (aí) que não é aqui nem lá no qual nós sempre já nos movemos.

\footnotetext{
${ }^{583}$ Derrida, Heidegger: la question de l'Être et l'Histoire, 2013, p.138

584 "O ente pode ser determinado em seu ser, não sendo preciso para isso que o conceito explícito do sentido do ser já deva estar disponível." (Heidegger, Ser e Tempo, 2012, §2, p.47)

${ }^{585}$ Derrida, Heidegger: la question de l'Être et l'Histoire, 2013, p.142

${ }^{586}$ Heidegger, Ser e Tempo, 2012, §7

${ }^{587}$ Heidegger, Ser e Tempo, 2012, $\$ 32$
} 
Este círculo apontaria justamente para a impossibilidade de um ponto de partida puro e a necessidade mesma de partir de um pré-ontológico, do que vimos, ainda que implicitamente em Ser e tempo, de uma diferença ontico-ontológica. O Dasein é este ente que se move nesta diferença, nem somente ôntico, nem somente ontológico, por isso seu privilégio pré-ontológico ${ }^{588}$. O espaço deste ente é marcado por esta diferença, seu círculo histórico-hermenêutico possui possibilidades ônticas (conceitos populares e da tradição) e possibilidades originárias e ontológicas, a partir das coisas elas mesmas ${ }^{589}$. Não haveria, assim, proximidade nem distância sem a própria diferença. Talvez, esta diferença seja mais importante que o ser e o ente ${ }^{590}$, ela vai mostrar a história como inscrição desta diferença $^{\mathbf{5 9 1}}$. Derrida parece sugerir ${ }^{592}$ que a diferença se mostra como algo talvez mais radical que o próprio ser e ente, autêntico e inautêntico, estes seriam cúmplices, duplos, não existiriam em separado. A diferença seria mais fundamental que a autenticidade pura, virgem e mítica ${ }^{593}$.

Vimos então que o círculo hermenêutico aponta para uma historicidade em que se dá num espaço aí, ôntico-ontológico aberto pelo Dasein. Circularidade esta da qual não podemos nos livrar, ela já-sempre deu lugar à questão do ser, nos provocando e nos tomando. Tal historicidade carregaria consigo possibilidades ônticas da tradição, dissimulando o ontológico, contando histórias a partir de metáforas (ônticas), e também possibilidades de abertura ao desvelamento do originário-ontológico. A partir daí veremos que Heidegger vai começar a descrever em Ser e tempo o campo inautêntico e o autêntico, em todos as estruturas existenciais do Dasein, inclusive a da historicidade.

Este campo histórico hermenêutico é onde todo Dasein se encontra imerso. A relação Ser, Linguagem e Dasein como o ente falante, questionante que pre-

\footnotetext{
${ }^{588}$ Vai ficando mais clara a segunda certeza - a pergunta acerca da exemplaridade do Dasein à respeito de sua historicidade em relação a história do Ser.

${ }^{589}$ Heidegger, Ser e Tempo, 2012, p.433 "O decisivo não é sair do círculo, mas nele penetrar de modo correto [...] [ele] é a expressão da existencial estrutura-do-prévio do Dasein ele mesmo. [...] Nele se abriga uma possibilidade positiva de conhecimento o mais originário, possibilidade que só pode ser verdadeiramente efetivada de modo autêntico, se a interpretação [hermenêutica] compreende que sua primeira, constante e última tarefa consiste em não deixar que o ter prévio, o ver-prévio e o conceber prévio lhe sejam dados por ocorrências e conceitos populares, mas em assegurar do tema científico mediante sua elaboração a partir das coisas elas mesmas."

${ }^{590}$ Derrida, Heidegger: la question de l'Être et l'Histoire, 2013, p.143

${ }^{591}$ Derrida, Heidegger: la question de l'Être et l'Histoire, 2013, p.108

${ }^{592}$ Derrida, Heidegger: la question de l'Être et l'Histoire, 2013, p.108

${ }^{593}$ Derrida, Heidegger: la question de l'Être et l'Histoire, 2013, p.130. Veja também Derrida, Heidegger: la question de l'Être et l'Histoire, 2013, p.106
} 
compreende ser, aponta a necessidade de se passar pela historicidade do Dasein para falar da história do Ser. Uma vez que pré-compreendendo sentidos e significados de ser, determinados a partir de uma linguagem como casa do ser, o que se pre-compreende é a própria tradição, a cotidianidade, a história, se movendo no próprio círculo hermenêutico. O que se descreve e Derrida parece apontar para este caminho é a história do Dasein e depois do Ser como a história desta diferença (ôntico-ontológica). Novamente damos atenção à seguinte passagem: “a questão do ser é a questão mesma da história. Ela nasce da história, e ela visa à história. Ela é a absolvição da história ela mesma sobre ela-mesma como história do ser." ${ }^{, 594}$ Os limites de nossa história, nós - humanos - (quem?) estariam, talvez, inscritos nos limites da diferença ôntico-ontológica. Seria possível alargarmos estes limites? Em que medida ainda haveria certo enclausuramento nestas margens? Sobretudo no que diz respeito à relação com o que se compreende por humano: em que medida, a relação (proximidade) serente-(Dasein) é um privilégio de todos os humanos? De toda a humanidade? Em que medida as épocas e o destino do ser marcam e delimitam a história desta humanidade? Qual humanidade? Como marcar tais limites? Talvez consigamos nos aproximar de possíveis caminhos para compreendermos tais perguntas.

$\mathrm{Na}$ cienquième seance, Derrida busca esclarecer e articular a destruição heideggeriana de subjetividade, em $O$ tempo da imagem no mundo (Die Zeit des Weltbildes - 1938), à noção de historicidade do Dasein em Ser e tempo. Segundo ele, Heidegger teria deixado claro que a concepção de mundo, descrita nesta obra de 1938 faria parte apenas de uma época. Uma vez que cada época teria um sentido $^{595}$ diferente e, os gregos, os romanos e a idade média não tinham imagem de mundo, ou seja, para eles o mundo não era uma totalidade de entes ordenados pela representação de um sujeito. Mundo grego e mundo medieval não tinham visão de mundo, nem representação, muito menos sujeitos e objetos. O que diz Heidegger aqui estaria coerente com o tema da historicidade do mundo, já que o mundo se mundanizaria a partir da transcendência do Dasein, sendo, deste modo, histórico de ponta a ponta ${ }^{596}$. Poderíamos, talvez, dizer que haveria diferentes mundos, ou seja, que haveria diferentes sentidos em cada época. A concepção de

\footnotetext{
${ }^{594}$ Derrida, Heidegger: la question de l'Être et l'Histoire, 2013, p.83

${ }^{595}$ Derrida, Heidegger: la question de l'Être et l'Histoire, 2013, p.198

${ }^{596}$ Derrida, Heidegger: la question de l'Être et l'Histoire, 2013, p.198
} 
mundo, o nosso mundo, esta época, não poderia ser em parte determinada de uma forma e em outra de modo distinto. "O mundo é todo inteiro e de ponta a ponta aquilo que ele é determinado [...] O mundo é todo inteiro na época, ele não é nada diferente disso. ${ }^{, 597}$ A imagem de mundo seria impossível no mundo medieval e menos ainda nos gregos. Neste momento Derrida vai descrever justamente o que já teria sido apontado nesta pesquisa, ainda que brevemente, sobre a problemática fechada das épocas de mundo heideggerianas. A historicidade e o mundo são inteiramente determinados por um modo de ser, de maneira que não haveria Dasein sem mundo ou sem historicidade, mas apenas deficiente desta (Cf. Ser $e$ tempo). Para que o mundo se tornasse imagem de mundo, o autor francomagrebino nos descreve:

Isto quer dizer que apesar das diferenças das épocas grega, medieval e moderna, existe uma unidade, a unidade de uma grande época do mundo, comandada pela filosofia como destino da Europa e que vê o desenvolvimento do mundo como objetidade, de Platão à Husserl. Aquilo que se anunciava com Platão se explicita com o Deus da filosofia da Idade média, vem à sua realização desde Descartes, Kant e Hegel e a ciência e a técnica moderna. ${ }^{598}$

Nas palavras do próprio Heidegger, "talvez se manifeste mesmo pela discussão da diferença de ser e ente, na de-cisão [na diferença], algo comum, que perpassa o destino do ser desde o começo até sua plenitude" ${ }^{, 599}$. Este algo comum, esta unidade parece ser seu objetivo desde o início de seu pensamento, ele confessa:

o começo de todo o meu pensamento origina-se numa frase de Aristóteles que diz que o ente é expresso de muitas maneiras. Na verdade esta frase foi a faísca que provocou a pergunta: qual é a unidade destes significados múltiplos de ser; na verdade, o que significa ser? $?^{600}$

Para Heidegger, Derrida acrescenta, estar determinado por uma época não significaria de modo algum querer abandoná-la, escapando ou a recusando, com objetivo de ir até outro mundo, até outra época. O que acontece é que o mundo inteiro, de ponta a ponta é determinado pelo modo de ser de uma época, de maneira que sua escapatória ou recusa não pode se dar de modo arbitrário. Neste sentido devemos pensar o sentido de nossa época para que ela pudesse aparecer

\footnotetext{
${ }^{597}$ Derrida, Heidegger: la question de l'Être et l'Histoire, 2013, p.199

${ }^{598}$ Derrida, Heidegger: la question de l'Être et l'Histoire, 2013, p.199-200 [Grifado nosso]

${ }^{599}$ Heidegger, A constituição Onto-teo-lógica da Metafísica In. Identidade e diferença,1973, p.397. (Grifado nosso).

${ }^{600}$ Heidegger, Seminários de Zollikon, 2001, p.145 (Grifado nosso)
} 
como aquilo que ela é, por exemplo, pela voz de um autor, de um pensador, de um poeta, talvez.

Isto supõe que ela [época] escapa a ela mesma, que ela não faz simplesmente um com ela e que já uma sombra a divide pela qual seu sentido presente lhe aparece e seu futuro se anuncia. Um certo suporte ao incalculável e a sombra que permite pensar o motivo da calculabilidade como aquilo que ele é. É aí que a questão sobre a essência da metafísica e dos tempos modernos começa a se desenvolver. Esta questão - questão sem resposta para o momento, a resposta diante do ser, abre sobre a historicidade em geral, a historicidade do ser, como o movimento e o encadeamento das épocas. Esta questão só é possível se aquele que a põe não pertence mais simplesmente a uma época, ou seja, à totalidade do ente, mas à diferença entre o ser e a totalidade do ente. ${ }^{601}$

Ser e tempo não articularia ainda tão claramente a historicidade do ser do ente, mas de algum modo, esta obra já começaria a apontar a entidade do ente determinada como presença, o privilégio do presente na filosofia, desde os gregos e mais fortemente a partir de Descartes como presença sob a forma de consciência $^{602}$. Desta forma, esta obra já nos mostraria o fechamento do ente a partir de uma forma determinada, que é o ente presente.

Fora deste fechamento, o ser da entidade e por consequência o ser da consciência não é pensado na sua verdade, e ainda menos pensado na sua historicidade. $\mathrm{O}$ horizonte escondido do ser - que permite ao ente aparecer como aquilo que ele é, em sua entidade - este horizonte é subtraído à história. [compreendida pelo impróprio]. ${ }^{603}$

Visto que a filosofia e não só ela, falaria apenas de uma história limitada por uma época do ser - onde o ser é determinado como ente, e mais determinado ainda, como presença na representação de uma consciência. Segundo Derrida, Ser e tempo seria o anúncio do fim desta época. É justamente esta limitação do ser como entidade determinada como presença, que Heidegger quer destruir, transgredir e pensar. A partir dela, da presentidade da presença, que a extensão ou síntese organizaria e unificaria os sentidos, ela seria a unidade de totalização, seria a própria história, para metafísica clássica ${ }^{604}$. Como pensar esta síntese sem nos voltarmos a uma consciência ou a uma força no modelo da presença adiante da mão (Vorhandenheit) ${ }^{605}$ ? Tudo aconteceria, para Heidegger, em torno do privilégio da presença ${ }^{606}$ e da subjetividade ${ }^{607}$. Solicitando (destruindo) a

\footnotetext{
${ }^{601}$ Derrida, Heidegger: la question de l'Être et l'Histoire, 2013, p.201

${ }^{602}$ Derrida, Heidegger: la question de l'Être et l'Histoire, 2013, p.216

${ }^{603}$ Derrida, Heidegger: la question de l'Être et l'Histoire, 2013, p.217

${ }^{604}$ Derrida, Heidegger: la question de l'Être et l'Histoire, 2013, p.218

${ }^{605}$ Que acabaria se tornando uma instância a-histórica.

${ }^{606}$ Derrida, Heidegger: la question de l'Être et l'Histoire, 2013, p.207
} 
evidência mais fundamental e irredutível da totalidade da metafísica, da filosofia mesma, ou seja, a presentidade da presença, Heidegger procuraria encontrar a possibilidade da própria historicidade ${ }^{608}$. Solicitando a época que dissimula a história do ser sobre a história da entidade como presentidade ${ }^{609}$, Heidegger nos mostra que a unidade de totalização, a história mesma teria sido pensada a partir da ideia de presença e, posteriormente, de subjetividade. Destruindo a tradição, ou seja, a história desta presentidade, ele abriria espaço para pensar a historicidade do ser, que como vimos em Ser e Tempo, será a partir da historicidade do Dasein. Segundo Derrida, época do ser em Heidegger diz respeito à:

Época do ser, o que quer dizer por sua vez, período e suspensão, retiro suspensivo pelo qual o ser, em sua época se retira e se esconde, se põe entre parênteses no seu movimento historial, sobre sua determinação ôntica em geral, e outras determinações mais determinadas em seguida. ${ }^{610}$

Derrida vê em Ser e tempo a descrição de uma certa epocalidade, ainda que de maneira não muito clara. Reconhecendo as limitações desta obra, ela já anunciaria um fechamento da metafísica a partir do modo de ser do ente presente, época que dissimula a história do ser, mas que faz parte dela ${ }^{611}$. Ou seja, a inautenticidade desta dissimulação está inscrita na estrutura mesma do Dasein, da historicidade do Dasein e posteriormente na história do ser. Futuramente, Heidegger começaria a determinar estas épocas de maneira cada vez mais clara. E teria visto a insuficiência de Ser e tempo para anunciar tais questões epocais. Heidegger para destruir a metafisica, nos descreve Derrida, deve a confirmar, só escapa do presente, da presença do presente como determinação de ser, fazendo como tema esta dissimulação do sentido de ser na presença, esta dissimulação como história, de uma forma grega de dissimulação à forma pós cartesiana $^{612}$... fazendo como tema as épocas da metafísica e a metafísica como época. A eficácia destes gestos agressivos em relação à metafísica, se mantém prisioneiros do que buscam, eficácia sonâmbula que será, talvez, a própria essência da metafísica. Uma certa exclusão para se auto definir.

Semelhante conclusão que Derrida anuncia em sua conferência Os fins do homem, como vimos, segue a passagem novamente:

\footnotetext{
${ }^{607}$ Derrida, Heidegger: la question de l'Être et l'Histoire, 2013, p. 218

${ }^{608}$ Derrida, Heidegger: la question de l'Être et l'Histoire, 2013, p.209

${ }^{609}$ Derrida, Heidegger: la question de l'Être et l'Histoire, 2013, p.218

${ }^{610}$ Derrida, Heidegger: la question de l'Être et l'Histoire, 2013, p.217

${ }^{611}$ Cf. Derrida, Heidegger: la question de l'Être et l'Histoire, 2013, p.218

${ }^{612}$ Derrida, Heidegger: la question de l'Être et l'Histoire, 2013, 217-218
} 
Mantém-se que o ser que não é nada, que não é um ente, não pode ser dito, não pode dizer-se senão na metáfora ôntica. E a escolha desta ou daquela metafórica é necessariamente significante. É na insistência metafórica que se produz então a interpretação do sentido do ser. E se Heidegger desconstruiu radicalmente a autoridade do presente na metafísica, foi para conduzir a pensar a presença do presente. Mas o pensamento dessa presença nada mais faz do que metaforizar, por uma necessidade profunda e à qual se não escapa por uma simples decisão, a linguagem que ele desconstrói. ${ }^{613}$

Fica mais claro que a condição da história, ou do movimento histórico acaba supondo uma solicitação ou uma destruição do privilégio do presente na metafísica, que não seria de modo algum evitável, mas, como vimos, seria parte da estrutura do próprio Dasein, da historicidade do Dasein e da História do ser. O que acontece é que esta dissimulação deve ser posta a prova, deve ser confirmada esclarecida e resguardada, para ser destruída e a história desta dissimulação se transformaria no próprio movimento histórico, nas épocas da metafísica e na metafísica como época ${ }^{614}$.

Derrida termina seu curso como uma introdução à introdução, nos dizendo que o que é dito por Heidegger não pertenceria a ele, mas à época e a proposição total da época, ao enunciado total da época. Retoma, assim, a passagem de carta Sobre o humanismo onde Heidegger nos diz “ a cada momento histórico, só existe um único enunciado daquilo que o pensamento tem a dizer que seja segundo a natureza mesma daquilo que ela tem a dizer."615 "Pertence a coisa do pensamento [...] que um só dizer [...] que seja a medida de sua Sachheit [coisidade]." ${ }^{, 616}$ Este um que diz, que atravessa, que é a medida, fala também através de Heidegger, de modo que este fala a "fala" da época. "O caminho do pensamento heideggeriano se dava ele mesmo como epocal e histórico, ou seja, como metafórico." ${ }^{617}$ Vimos que o pensamento do ser seria aquele que anunciaria o horizonte da não metáfora a partir do qual a própria metaforicidade é pensada. Falar da questão de ser já seria determinar metaforicamente o código da não metáfora. $\mathrm{O}$ gesto é metafórico

\footnotetext{
${ }^{613}$ Derrida, Os fins do homem, 1991, p.172

${ }^{614}$ Derrida, Heidegger: la question de l'Être et l'Histoire, 2013, p.228

${ }^{615}$ Derrida, Heidegger: la question de l'Être et l'Histoire, 2013, p.324

616 Derrida, Heidegger: la question de l'Être et l'Histoire, 2013, p.324 "Der Sache des Denkens gehört je geschichtlich nur eine, die ihrer Sachheit gemäße Sage." (Brief über den Humanismus In. Platons Lehre von der Wahrheit, 1947, p.18) Disponível em: http://laboratoirefig.fr/wp-content/uploads/2016/04/HEIDEGGERbrief_u\%CC\%88ber_den_humanismus.pdf Acesso em: 4 de março de 2016. "À questão propriamente dita do pensar pertence apenas uma saga (Sage), aquela que é adequada ao que constitui a essência da questão." (Heidegger, Sobre o humanismo, 1973, p.370)

${ }^{617}$ Derrida, Heidegger: la question de l'Être et l'Histoire, 2013, p.323
} 
e anuncia os que estão porvir. Este movimento de determinar a questão de ser metaforicamente - linguisticamente, não podemos não fazer apelo. A linguagem do ser nos determina. Não podemos fugir dela, recusá-la ou ultrapassá-la. "Só existe história do ser e o ser não é histórico, mas por essência esta preposição é ainda metafórica." ${ }^{618}$ A historicidade, talvez, seria vista, em Derrida como escritura, como rastro do sentido, sendo este o próprio processo metafórico. Derrida acentua também nesta obra que o próprio Heidegger, posteriormente teria cortado, rasurado, a palavra ser, "mostrando que a palavra ser pertence ainda a um pensamento da presença." Este deslocamento em Heidegger já foi apresentado em Gramatologia. A significação linguística da palavra ser é cortada, apagada. Este rastro apagando o rastro do presente na linguagem é a unidade da metaforicidade e da não metaforicidade, como unidade da linguagem ${ }^{619}$. Se a significação de ser é também uma metáfora, que foi posteriormente apagada, e se história é história do ser, a significação de história é também uma metáfora à destruir. Esta destruição não se daria de uma vez por todas, mas como uma auto-afecção daquilo que não mais podemos chamar de ser. O ser e história sendo ainda metafóricos, a destruir, são, por outra metáfora o porvir mesmo. Aquilo que se esconde sobre esta outra metáfora é a abertura da questão, ou seja, a diferença. ${ }^{620}$

\section{5}

\section{Geschlecht}

Para finalizar este capítulo, seria de extrema importância, passarmos, ainda que de modo breve, aos textos que dialogam com a Geschlecht, as Geschlecht heideggerianas. Estes textos vão, deste modo, tentar nos esclarecer mais um pouco acerca do dito humano no pensamento de Heidegger e no de Derrida. O autor franco-magrebino nos chama a atenção para a amplitude da dimensão semântica da palavra Geschlecht, tornando-a deste modo, de difícil tradução. Ela, a palavra Geschlecht, remeteria à sexo, raça, família, geração, linhagem, espécie, gênero, e

\footnotetext{
${ }^{618}$ Derrida, Heidegger: la question de l'Être et l'Histoire, 2013, p.323

${ }^{619}$ Derrida, Heidegger: la question de l'Être et l'Histoire, 2013, p.325

${ }^{620}$ Derrida, Heidegger: la question de l'Être et l'Histoire, 2013, p.325-326
} 
muito posteriormente será tomada por Heidegger, a partir do texto O Poema de $\operatorname{Trakl}^{621}$ (1953), e relacionada com a palavra golpe (Schlag) ${ }^{622}$ no idioma alemão.

Começaremos acenando alguns pontos importantes trazidos por Derrida na conferência de 1983 intitulada Geschlecht, différence sexuelle, différence ontológique, nela o autor dialoga principalmente com a obra Ser e Tempo (1927) e com o curso de verão de Marburg O Problema da Trancendência e O Problema de Ser e Tempo (1928). Neste último, Heidegger teria se explicitado melhor quanto ao tema da transcendência e quanto a analítica existencial como uma fase preparatória para a questão acerca do sentido de ser. Alguns temas são de início assinalados e Derrida aponta, ao que nos interessa aqui, a temática da neutralidade do Dasein. A partir dela o autor sublinha que, sendo neutro, o Dasein não portaria, assim nenhuma marca sexual, e que a diferença sexual, não estaria deste modo a altura da diferença ontológica. O que estaria em jogo aqui, seria justamente o caráter derivado das determinações metafísicas, antropológicas, éticas, humanistas do humano. Determinações estas que são tratadas no campo das ciências humanas e psicológicas como óbvias. O que Heidegger teria feito, seria dar um passo atrás para pensarmos um pré do Dasein que não fosse marcado por tais características e, por isso, o autor alemão teria, logo de início, acentuado a neutralidade deste ente que não possuindo estas determinações metafísicas teria como traço apenas um tipo de relação a si, a relação ao ser do ente ${ }^{623}$.

$\mathrm{O}$ que acontece em seguida, surge da sentença heideggeriana em que o caráter neutral significaria também que ele não é nenhum dos dois sexos. Dois pontos em especial teriam chamado à atenção de Derrida: 1) Heidegger não teria duvidado que seriam dois [sexos]. 2) Por que Heidegger teria dado atenção especial se precavendo e explicitando que a neutralidade seria também com relação à diferença sexual? Um outro ponto teria sido abordado em seguida a respeito da positividade desta neutralidade, uma vez que ela não levaria ao Dasein para um isolamento negativo ou uma asexualidade negativa, pelo contrário, a

\footnotetext{
${ }^{621}$ A tradução em português foi intitulada A linguagem na poesia: Uma colocação a partir da poesia de Georg Trakl In. Caminhos da linguagem, Petrópolis, RJ : Vozes; Bragança Paulista, sr : Editora Universitária São Francisco, 2003. (pp.27-70). Mantivemos no texto a palavra poema traduzido de poem como utilizado em Derrida, Heidegger's Hand (Geschlecht II) In. Psyche, Inventions of the Other vol.II, 2008.

${ }^{622}$ Derrida, Geschlecht, différence sexuelle, différence ontológique, In. Cahier de l'herne, [nota 1], 1983, p.430

${ }^{623}$ Derrida, Geschlecht, différence sexuelle, différence ontológique, In. Cahier de l'herne, 1983, p. 421
} 
neutralidade apontaria para uma positividade originária, talvez, pré-dual, présexual. A interpretação de Derrida vai em direção a este último apontamento, ele mesmo nos diz que o negativo estaria assentado sobre a dualidade sexual e a neutralidade (efeito da negatividade) viria como que a apagando, apagando o pensamento dual, para deixar, então aparecer a positividade originária e a potencialidade (Mächtigkeit) de ser.

Heidegger teria, assim, buscado mostrar que o caráter neutro do Dasein seria positivo, não apontaria a um isolamento completo, mas uma certa dispersão (Zerstreuung) fática na corporiedade e, com isso, na sexualidade. O Dasein estaria em cada caso faticamento cindido, dividido numa determinada sexualidade. Dispersão e neutralidade devem ser encaradas de modo positivo e pertenceriam a transcendentalidade deste ente ${ }^{624}$. Estando assentadas sobre o caráter de jogado (jetée) do Dasein, caráter este anterior ao projeto (projet), sujeito (sujet), objeto (objet), trajeto (trajet). A pertença ao gênero passa a ser elucidada após este jájogado, disperso, como ser-com, a partir do impessoal (ser-com impróprio). Uma vez que eu-Dasein só poderia me determinar a partir de um mundo cotidiano impessoal, sendo como eles são. O que Heidegger estaria tentando evitar seria pensar a partir da doxa comum, a partir destas determinações tomadas como óbvias e não questionadas à luz da questão do ser. Sem dúvida o aceno não seria para uma exclusão de tais características (doxa comum) e Heidegger deixa isto claro diversas vezes, mas para uma derivação a partir do que é mais próprio do Dasein, sua existência como compreensão de ser, como relação com o ser do ente. O que Derrida nos pergunta é: qual seria o preço desta prudência? Não seria distanciar a sexualidade [a determinação sexual] das estruturas originarias? Deduzindo-a e derivando-a? Confirmando, assim, os filosofemas mais tradicionais, os repetindo, com a força de um novo rigor? $?^{625}$

Outro ponto que Derrida nos chama a atenção, e que ele fará também com a palavra espírito em Heidegger que veremos mais adiante, é mostrar como as palavras neutralidade e dispersão, estariam por um lado relacionadas à positividade e originariedade do Dasein, como vimos aqui, e por outro, aparecem, na estrutura imprópria, derivada, da cotidianidade, como o impessoal neutro, por

\footnotetext{
${ }^{624}$ Heidegger, el problema da transcendencia y el problema de ser y tiempo, In. Princípios metafísicos de la lógica, 2007, p.160-162

${ }^{625}$ Derrida, Geschlecht, différence sexuelle, différence ontológique, In. Cahier de l'herne, 1983, p. 428
} 
exemplo, e a curiosidade dispersa da decadência. Autenticidade e inautenticidade, originário e dissimulação pertencem aos movimentos do Dasein e da história do ser e de sua interpretação. Se Derrida, por um lado, questiona esta divisão heideggeriana alegando que ela possuiria certa herança cristã, platônica, de um lugar puro originário a uma queda ou corrupção ${ }^{626}$. Por outro, aponta a intenção de Heidegger tentar mostrar que ambos os lados são positivos, uma vez que buscariam evitar, estes mesmos esquemas éticos, religiosos, dialéticos em que um lado seria mais puro que outro ${ }^{627}$.

Para finalizar nosso diálogo com este primeiro Geschlecht algumas perguntas, sem respostas, foram trazidas por Derrida e devem ser apontadas, enviadas para nossa reflexão com relação ao dito humano. E se a diferença sexual fosse já marcada nesta abertura [ao ser], na diferença ontológica? Se o aí ( $D a)$ do ser-aí [Dasein] fosse já sexual? E se a neutralização fosse uma operação violenta? ${ }^{628}$ Talvez, ao perguntar sobre a violência da neutralidade, Derrida também estaria questionando o discurso por trás desse lugar. $\mathrm{O}$ neutro, muitas vezes pressupõe certa isenção de partes, um estar fora do jogo, quase como uma pureza, uma origem, já apontados por Derrida em diversos textos como discursos perigosos. Uma vez que, não haveria fora-jogo, fora texto, pureza e origem. Tais discursos são comuns, por exemplo, no nosso dia a dia, mas também nos discursos do direito, da política, mas sobretudo, e nos interessa aqui, nos discursos da clínica psicológica, onde se ouve comumente que um psicoterapeuta deve ser neutro e isento de julgamento. Esta postura muitas vezes requerida, sem dúvida buscaria uma colocação mais justa, menos preconceituosa, mais neutra. Mas se tal busca de neutralidade pode por um lado servir para desconfiar dos discursos óbvios e preconceituosos da cotidianidade, para usar um termo heideggeriano. Por outro, pode carregar pretensões - estas que estamos apontando aqui - de neutralidade, pureza, verdade, boa consciência, que recairiam, talvez nos mesmos preconceitos. Como poderíamos pensar este posicionamento clínico na psicoterapia a partir deste intervalo entre a pretensão à neutralidade e o

${ }^{626}$ Derrida, Geschlecht, différence sexuelle, différence ontológique, In. Cahier de l'herne, 1983, p. 426

${ }_{627}$ Derrida, Geschlecht, différence sexuelle, différence ontológique, In. Cahier de l'herne, 1983, p. 429

${ }^{628}$ Derrida, Geschlecht, différence sexuelle, différence ontológique, In. Cahier de l'herne, 1983, p.424-425. Heidegger teria acenado para o caráter sexual também em A essência do fundamento (1928), quando nos descreve que a ipseidade é também neutra, principalmente à respeito da sexualidade. Qual a necessidade, nos questiona Derrida, de dizer principalmente? 
preconceito não questionado? Deixo a pergunta em aberto.

Derrida finaliza a conferência com estas reflexões: o que seria um discurso "sexual", "sobre a sexualidade" que não apelaria ao distanciamento, ao dentro e fora, à dispersão e à proximidade, ... ao ser-com e ao discurso? Esta ordem de implicações abriria, talvez à um pensamento de uma diferença sexual que não seria ainda dualidade sexual, diferença como dual. Derrida mesmo acena para a possibilidade de pensarmos, talvez, "um outro sexo, ou melhor, um outro Geschlecht que viriam se inscrever na ipseidade." ${ }^{629} \mathrm{O}$ curso de Heidegger neutralizaria menos a sexualidade que a pertença a um dos sexos. Portanto, reconduzindo à dispersão não poderíamos pensar uma diferença sexual (sem negatividade) que não fosse firmada pelo dois? A retirada desta dualidade até outra diferença sexual prepararia ainda outras questões, por exemplo, como a diferença é arquivada no dois? $?^{630}$

Derrida pouco depois deste ensaio, realiza uma conferência em 1985 acerca da mão de Heidegger, intitulado Geschlecht II : la main de Heidegger, onde ele começaria a apontar uma questão que muito nos interessa aqui e que será posteriormente desenvolvida em outra conferência intitulada De l'esprit: Heidegger et la question (1987). O tema ou a hipótese que gostaríamos de apontar aqui estaria por um lado relacionada a universalidade do Dasein heideggeriano, bem como de tudo que compreende este ente, sua relação com o ser, com a linguagem, com o como tal e com as essêncializações das épocas do ser. Por outro, em que medida, talvez este ente, sua linguagem, seu modo de ser e sua relação/determinação/essencialização com e a partir das epocalidades do ser estariam reunidas e inseparadas da Geschlecht europeia, mais precisamente a alemã, do idioma alemão, talvez, do modo de ser de uma "humanidade" alemã. O desenvolvimento deste outro lado nos fará questionar a necessidade, talvez, do discurso heideggeriano ser analisado a partir destas heranças e desta Geschlecht, acenando, assim, para certa atenção quando um discurso, uma psicologia clínica o toma como uma fala que vem abrir o pensar e a relação acerca do humano. Nesse sentido, tomar o discurso de uma psicologia assentada sobre o pensamento de

\footnotetext{
${ }^{629}$ Derrida, Geschlecht, différence sexuelle, différence ontológique, In. Cahier de l'herne, 1983, p. 425

${ }^{630}$ Derrida, Geschlecht, différence sexuelle, différence ontológique, In. Cahier de l'herne, 1983, p.430
} 
Heidegger deve, ao menos, atentar para a possibilidade de seus próprios limites.

Outro tema importante estaria relacionado aos limites deste discurso com relação à herança de uma tradição de pensamento que coloca de um lado nós humanos, uma Geschlecht e de outro os animais em toda a homogeneidade que esta palavra carrega. Este tema não será desenvolvido aqui, mas é bem trabalhado num livro póstumo chamado L'animal que donc je suis, publicado em 2006.

Na conferência la Main de Heidegger Derrida vai nos mostrando como a mão em Heidegger teria um papel importante desde Ser e tempo ${ }^{631}$ com a manualidade (Zuhandenheit), o manual (Zuhanden) e o ente presente adiante da mão (Vorhanden) até os textos mais tardios, como o Was heisst denken (1954) quando apontaria o Handwerk (manobra - ofício) do Schreiner (carpinteiro) por trás da relação da essência do homem com a madeira, o pensador, o poeta e o Ser. Também no texto Parmenides (1942-1943) com a relação entre a mão e a máquina de escrever e a reunião ${ }^{632}$ entre Ser, Logos, leitura, escrita (schrift) e manuscritura (Hand-schrift).

O que vai nos interessar aqui primeiramente estaria relacionado à divisão, ao limite e à reunião por trás de um discurso onde o Dasein é o ente, nós mesmos, que tem acesso ao como tal, à essência das coisas e à relação e abertura ao ser. Para Heidegger, nós, os humanos - (que humanos?) - teríamos mãos. Ter mão estaria por trás do pensar, da fala e da linguagem em Was heisst denken. Já os animais não teriam mãos, sendo agrupados numa homogeneidade: animal. A sentença se refere precisamente aos macacos que não teriam mãos, mas órgãos de preensão. E por isso não teriam acesso a tudo que viria reunido ${ }^{633}$ à mão heideggeriana neste contexto: o pensar, a linguagem, o Ser, às épocas do ser, a abertura e o mundo (os animais são pobres de mundo, limitados em sua abertura ao mundo). A Geschlecht humana e a Geschlecht animal estariam inscritas e descritas em um discurso herdado e muitas vezes inquestionado. Sem dúvida tal inquestionamento vai também em direção de nossas perguntas acerca dos humanos, sujeitos excluídos a partir de determinados discursos que se auto dizem

\footnotetext{
${ }^{631}$ É importante acentuar que Derrida vai trabalhar outros textos heideggerianos nesta conferência, além dos exemplificados aqui. Nos mostrando a importância da mão em cada um deles. Nós não vamos nos debruçar em cada um deles.

${ }^{632}$ Derrida, Heidegger's Hand (Geschlecht II) In. Psyche, Inventions of the Other vol.II, 2008, p. 47

${ }^{633}$ Derrida, Heidegger's Hand (Geschlecht II) In. Psyche, Inventions of the Other vol.II, 2008, p. 41
} 
mais dignos, mais verdadeiros, mais neutros, mais essenciais, mais humanos.

Outro caminho trilhado por Derrida nesta conferência vai em direção à Geschlecht heideggeriana que vai tratar sempre de nós os humanos e reúne nela, nesta palavra, a multitude semântica que ela carrega: raça, família, linhagem, gênero, genealogia, sexo, ... Derrida nos mostra esta relação Geschlecht humanos em passagens de Was heisst denken e O Poema de Trakl. Neste último ele vai trabalhar a afinidade entre Schlag (golpe) e Geschlecht que só poderia ser relacionado a partir do idioma alemão, ou melhor, a partir do idioma de um poema singular, aqui o de Trakl e do idioma do pensar que passa por Heidegger. ${ }^{634}$ Idiomas estes que estão relacionados à manobra - mão de obra - heideggeriana, uma manobra, sobretudo, de escrita que recorre em momentos decisivos a um recurso idiomático, recurso não só do idioma alemão, mas do alto ou antigo alemão. Se remetendo com frequência ao antigo alemão cada vez que ele começa a dizer: em nossa língua, tal palavra significa originariamente ${ }^{635}$. Acentua ainda que devemos lembrar que em Heidegger Poesia e Pensamento são trabalhos da mão assim como o Handwerk do carpinteiro e que não estariam no mesmo patamar nem lugar que a filosofia e a ciência, muito menos, talvez, a psicologia ou as ciências humanas que estariam por isso excluídas ${ }^{636}$ deste lugar e do que viria com ele. Neste sentido, Derrida nos pergunta, como pensar esta reunião (que busca uma situação única) do Gedicht (poema) num único lugar, num lugar próprio do Gedicht (do poema) em que os poemas, neste caso de Trakl falariam? ${ }^{637}$ Como pensar a unidade (lugar) da reunião? ${ }^{638}$ Como pensar a apropriação e pertença do Gedicht (ou mesmo do pensar) em uma língua e em uma Geschlecht ${ }^{639}$ Situação esta relacionada não só à Geschlecht e à língua alemã, mas também, ao homem e ao destino do Ocidente, tema este recorrente no trabalho de Heidegger.

\footnotetext{
${ }^{634}$ Derrida, Heidegger's Hand (Geschlecht II) In. Psyche, Inventions of the Other vol.II, 2008, p.56

${ }^{635}$ Derrida, Heidegger's Hand (Geschlecht II) In. Psyche, Inventions of the Other vol.II, 2008, p.59

${ }^{636}$ Derrida, Heidegger's Hand (Geschlecht II) In. Psyche, Inventions of the Other vol.II, 2008,

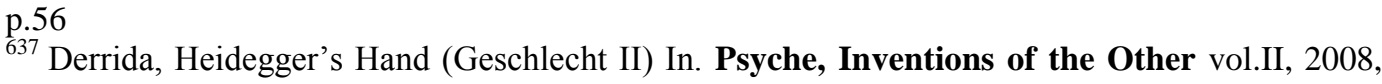
p. 58

${ }^{638}$ Derrida, Heidegger's Hand (Geschlecht II) In. Psyche, Inventions of the Other vol.II, 2008, p.62

${ }_{639}$ Derrida, Heidegger's Hand (Geschlecht II) In. Psyche, Inventions of the Other vol.II, 2008, p.60 (Grifado nosso)
} 
Vai ficando mais claro a partir de algumas questões de Derrida apontadas nesta pesquisa em que medida Heidegger estaria, às vezes, supondo uma unidade e reunião a partir de uma Geschlecht alemã, de um alemão alto e antigo, e/ou Ocidental (europeia). Como ficaria desta forma, este discurso em relação a um pensamento acerca do humano, da psicologia, da abertura do humano, não mais pensada a partir de pré-determinações apriorísticas sejam elas biológicas, éticas, antropológicas, psíquicas? De que forma esta abertura proposta por Heidegger nos faz questionar determinadas obviedades, mas talvez recaia em outras divisões, outros limites que acabam também sendo apropriados, repassados e inquestionados por aqueles que se utilizam do discurso deste autor? Nossa pesquisa vai aos poucos apontando estes limites acentuando, desconstruindo, costurando a partir do pensamento de Derrida. Costuras que o autor realizou uma vez que se debruçou sobre o grande tecido, grande texto que é Heidegger e suas obras. Tecido de extrema importância no pensamento da filosofia, das ciências humanas e da psicologia. É inegável sua contribuição, a importância de seu pensamento, de sua forma de caminhar, e Derrida sem dúvida concordaria. Ficam em aberto estes pequenos e breves espaços que tentamos desconstruir junto ao autor franco-magrebino com o intuito de não só acentuar certa cautela na escuta dos discursos, mas também em abrir à outros discursos, uma vez que o discurso heideggeriano não é o último e tampouco o de Derrida. São textos sobre os quais a desconstrução, as costuras e os caminhos são possíveis e necessários.

Na conferência De l'esprit: Heidegger et la question $(1987)^{640}$ Derrida vai também dialogar com esta reunião, união do povo alemão com a palavra Geist $\mathrm{e}$ Geschlecht. Se em Ser e Tempo esta palavra - Geist - deveria ser evitada, posteriormente ela passará a ser celebrada e intimamente relacionada ao povo alemão, à Geschlecht alemã. Aos poucos Heidegger iria se reapropriando da palavra espírito, que já em Ser e tempo aparece como aceitável, mas entre aspas, reapropriação esta que Derrida buscaria demonstrar como uma regermanização $^{641}$. A palavra espírito reapareceria para designar algo outro que o espírito que foi desconstruído, um espírito de outro espírito, como uma silhueta

\footnotetext{
640 "Do espírito foi a primeiramente uma conferência pronunciada no fechamento de um colóquio organizado pelo Collège International de Philosophie com o título de "Heidegger, questões abertas". Derrida, Heidegger, l'enfer des philosophes in. Point de suspension, (1987/1992), p.195. ${ }^{641}$ Derrida, De l'esprit: Heidegger et la question (1987), p.44 ; Del espíritu: Heidegger y la cuestión, 1987, p.15
} 
espectral $^{642}$. Derrida nos descreve que quando Heidegger aponta a relação formal entre espírito e tempo em que o espírito decairia no tempo, o autor retomaria a palavra espírito, desta vez, colocando-a entre aspas - "espírito" - para descrever uma temporalidade originária em que a decadência não seria mais do espírito no tempo (como seria em Hegel), mas do tempo autêntico no tempo inautêntico. Se existe uma relação formal do espírito com o tempo e Heidegger aponta não mais uma queda do espírito no tempo, mas do tempo (próprio) no tempo (impróprio). Então, talvez, Derrida nos questiona, deveríamos também pensar num espírito que decairia em outro espírito? ${ }^{643}$ Esta pergunta permanece em aberto. Teríamos, talvez, já em Ser e Tempo a possibilidade de dois espíritos, um próprio - "espírito" - apresentado no final da obra e outro impróprio - espírito - já questionado e evitado desde o início desta obra.

Em seguida o espírito se afirmaria desta vez sem aspas, através da autoafirmação da universidade alemã no texto Discurso de Reitorado (1933). O espírito agora se inflamaria. Ele - o espírito - escreveria seu traço de união entre mundo, história, povo, vontade de essência, de saber e a existência do Dasein na experiência da pergunta ${ }^{644}$. Neste capítulo Derrida nos chama a atenção para os discursos que se colocariam contra um discurso, talvez, fascista, em nome de uma democracia ou dos direitos do homem, em nome da liberdade do espírito, dos humanos. (Quais humanos?) Um espírito que reaparece fazendo de ventríloquo um outro. Haveria sempre o reaparecimento da metafísica, e aqui acrescentaríamos, talvez, do humano, e Geist seria a figura fatal desta reaparição. Ele reaparece tímido já em Ser e Tempo, mas ganha mais força pouco tempo depois na autoafirmação da universidade alemã. E assim o autor nos questiona: o inevitável não seria justamente este duplo espírito, o Geist como Geist do Geist, assombrado por seu Geist, o espírito como espírito do espírito, que viria sempre com seu duplo $?^{645} \mathrm{O}$ espírito sendo este duplo.

É em Introdução à metafísica (1935) que a palavra espírito viria como um

\footnotetext{
${ }^{642}$ Derrida, De l'esprit: Heidegger et la question (1987), p.45 ; Del espíritu: Heidegger y la cuestión, 1987, p.15

${ }^{643}$ Derrida, De l'esprit: Heidegger et la question (1987), p.50 ; Del espíritu: Heidegger y la cuestión, 1987, p.17 Derrida associa o espírito à temporalização e ao movimento de queda de um tempo originário em outro tempo derivado.

${ }^{644}$ Derrida, De l'esprit: Heidegger et la question 1987, p.63 ; Del espíritu: Heidegger y la cuestión, 1987, p.23

${ }^{645}$ Derrida, De l'esprit: Heidegger et la question 1987, p.66, Del espíritu: Heidegger y la cuestión, 1987, p.24
} 
diagnóstico Geopolítico acentua Derrida, uma vez que neste texto Heidegger denunciaria a decadência espiritual que não poderia ser pensada sem o destino do ser. Seria no povo alemão, nosso povo, exposto aos perigos, que recairia a grande decisão que comprometeria o destino da Europa e o desenvolvimento de novas forças espirituais. Se invoca assim, um novo começo com a pergunta que sucede com o ser a partir do qual seria possível um recomeço de nossa (nós - alemãs?) existência histórico espiritual. Derrida nos pergunta então, como despertar o espirito? Como despertá-lo para sua responsabilidade? A resposta, ele nos descreve, viria como um chamado à preocupação pela questão do ser, assumindo o envio de uma missão historial do nosso povo como centro do ocidente ${ }^{646}$. No Destino da língua se fundaria a relação de um povo ao ser. Assim se entrelaçaria: nosso povo, a questão do ser e nossa língua. É no começo do capítulo sobre a gramática da palavra "ser", que a qualidade espiritual vai definir o privilégio absoluto da língua alemã ${ }^{647}$. Trazendo as palavras de Heidegger, Derrida nos descreve que toda a força e autenticidade se fundariam no espírito que não encontraria sua elevação senão na decadência e na potência ou impotência do espírito $^{648}$. Um espírito autêntico precisa do inautêntico para sua autenticidade. Um Geschlecht autêntico precisa de um inautêntico. Poderíamos pensar, talvez, esta dupla relação acerca de um humano autêntico, normal, sadio, são, que precisaria de um humano inautêntico, anormal, doente, louco? A dobra espectral sempre em jogo. O jogo de substituições, jogo da diferança, que não necessariamente será duplo. Podemos nos perguntar novamente, a partir do momento que Heidegger acentua os privilégios de um povo alemão, de uma língua alemã, de uma decisão historial que recairia sobre um povo alemão, estaríamos nós em um discurso, talvez, fechado, em certo ponto com relação aos

\footnotetext{
646 "Estamos entre tenazes. A Alemanha, estando no meio, suporta a maior pressão das tenazes [referência à Rússia e América que em relação a sua atitude diante do espírito são a mesma coisa p.71]. É o povo que tem mais vizinhos e, desse modo, o mais ameaçado, mas em tudo isso, é o povo metafísico. Entretanto só poderá retirar para si desse destino [do ser], de que estamos certos, uma missão, se conseguir criar, em si mesmo, uma ressonância, uma possibilidade de ressonância para esse destino, concebendo sua tradição de modo criador. Isso implica e exige, que esse povo ex-ponha Historicamente a si mesmo e a História do Ocidente, a partir do cerne do acontecimento futuro, ao domínio originário das potências do Ser. Precisamente se a grande decisão sobre a Europa não seguir os caminhos da aniquilação, ela só poderá então seguir o caminho do desenvolvimento de novas forças espirituais-históricas a partir do centro [a Alemanha]." Heidegger, Introdução à metafísica, 1999, p.65.

${ }^{647}$ Derrida, De l'esprit: Heidegger et la question (1987), p.109; Del espíritu: Heidegger y la cuestión, 1987, p.41

${ }_{648}$ Derrida, De l'esprit: Heidegger et la question, 1987, p.104 ; Del espíritu: Heidegger y la cuestión, 1987, p.39
} 
discursos da humanidade do homem? Seria possível pensar discursos que não estariam destinados à esta programação? Programação também apontada no que Derrida chamou de logocentrismo, fonocentrismo, antropocentrismo, nos centrismos que se auto atraem excluindo àqueles que não podem fazer parte. Não é para este movimento inclusão-exclusão que Derrida vem tentando nos chamar a atenção? Movimento este que em Heidegger também aparece sobre a forma de dissimulação da história da metafísica ou do Dasein impróprio para pensar a História do ser ou um Dasein próprio?

Em 1953 no texto de Trakl, Derrida nos mostra que o espírito e todo o espiritual - Geistig - a ele relacionado e que havia sustentado a decisão historial, o recomeço com a pergunta acerca do ser e a relação destes elementos com o povo alemão seriam agora inscritos na forma recalcada, derivada da tradição metafísica cristã, também responsável pela decomposição (Verwesende) da Geschlecht. Heidegger falava em nome do que agora ele condena ${ }^{649}$. Enquanto em 1935 Geistigkeit era comum às línguas grega e alemã ${ }^{650}$, agora no texto de Trakl, Heidegger sugeriria que a língua grega não possui nenhuma palavra para traduzir Geist e que Geistigkeit estaria associada a uma herança platônico cristã, a uma herança metafísica. Não seria um rechaçamento das palavras pneuma e spiritus ${ }^{651}$, mas uma derivação do mais originário, relacionado ao Geistlich com o sentido que daria Trakl, sentido que viria sem dúvida do mais alto e antigo alemão. Podemos perguntar pelo privilégio da legitimidade desta originalidade, mas Derrida também nos pergunta acerca da clausura do próprio triângulo (gregolatim-alemão) em que Heidegger se manteria e desenvolveria seus discursos.

Se apresentamos brevemente estes textos foi para apontar a duplicidade contida nestes discursos heideggerianos, não só a partir da relação espírito autêntico, espírito inautêntico, mas Dasein autêntico e inautêntico, história autêntica e inautêntica, línguas autênticas e originárias e línguas derivadas. Toda

\footnotetext{
${ }^{649}$ Derrida, De l'esprit: Heidegger et la question (1987), p.154-155 ; Del espíritu: Heidegger y la cuestión, 1987. p.60

650 “O fato de a formação da gramática ocidental se ter originado da reflexão dos gregos sobre $a$ língua grega, confere-lhe toda a importância. Pois a língua grega, medida pelas possibilidades do pensamento, é, ao lado da alemã, a mais poderosa e a mais cheia de espírito." (Heidegger, Introdução à metafísica, 1999, p.85)

${ }^{651}$ Em Introdução à metafísica, Heidegger nos descreve que na tradução do grego para o latim houve distorções do conteúdo originário da palavra physis, por exemplo. E acrescenta, "isso vale não apenas para a tradução latina DESSA palavra, mas também de todas as outras traduções da linguagem filosófica da Grécia para a de Roma.” (Heidegger, 1999, p.44)
} 
esta duplicidade originário e derivado, com os termos e consequências que o seguem. E acentuarmos que esta originariedade se não está ligada apenas a um povo, o alemão, está também e mais amplamente relacionada ao ocidente, à história do ocidente, ao pensamento do ocidente, ao dito humano ocidental. Destacamos, sobretudo, que uma vez celebrando em nome dos raros, lembrei aqui dos raros médicos que pensam no texto de Zollikon, dos raros que pensam a partir da história do ser, excluímos de imediato os que não foram celebrados, os que não são raros, acentuando apenas os que pensam a partir de uma história e de uma abertura ao ser do ente como tal, abertura às essências historiais e epocais ${ }^{652}$. Quem seriam, se é que seriam, aqueles que foram excluídos? Como pensar esta exclusão a partir de discursos acerca do humano, da relação com o humano, de uma possível psicologia assentada sobre esta relação, assentada sobre estes discursos? Não pretendo aqui reforçar um caminho que sairia desta programação apontada por Derrida, mas acenar para a necessidade, talvez, de re-pensar, reinscrever tais discursos. Pensando e re-pensando seus assentamentos, seus duplos, seus espectros, fantasmas... seguindo envios herdados já pelo pensamento heideggeriano acerca de certa desconfiança com relação aos discursos óbvios, herança esta que Derrida parece assumir e reenviar.

Foi possível vermos neste capítulo, a partir de Derrida como o pensamento da diferança e do rastro passam pelo pensamento da diferença ontológica, mas talvez transbordando-o, na medida em que a diferança não acena para uma verdade, nem para uma essência, nem mesmo para uma origem. Mas para o jogo de substituição e suplementação característico do rastro e da escritura. Jogo violento que desequilibra o que parecia algo estável. Até mesmo o termo diferança está jogado nesta cadeia já encadeada que ele mesmo não governa. $\mathrm{O}$ sonho e a promessa de uma plena, pura presença a si foi desde sempre violentado. $\mathrm{O}$ que ele vem questionar é justamente os privilégios em jogo nos discursos que se dizem mais verdadeiros, mais humanos, mais essenciais, mais originários, excluindo aqueles que não o são. Pensar as margens, os limites e bordas destes discursos é desconstruí-los não de modo negativo, mas afirmativo, uma vez que se acrescenta, se alarga, reenvia, e remete, desequilibrando o que parecia estável. É

${ }^{652}$ Derrida, De l'esprit: Heidegger et la question, 1987, p.122; Del espíritu: Heidegger y la cuestión, 1987, p.47. (Como o homem tem uma relação privilegiada com o ente enquanto tal sua abertura frente ao que é enviado - destinado, lhe confere uma historicidade essencial que o permite ser e ter uma historia). 
neste sentido também que Derrida acena para uma derivação não de um originário, mas de outro derivado, numa cadeia suplementar infinita. Não haveria presença a si, plena de si, fechada, unificada e resguardada. Mas uma identificação necessita que algo a separe, um entre, um intervalo, para que ela seja ela mesma. É por não haver unidade consigo mesma, que haveria suplementaridade, jogo de transbordamento e apagamento, se remetendo, auto remetendo, alargando e substituindo o que já não era. Estes elementos foram desdobrados, sobretudo, a partir de seu texto Gramatologia.

Com relação ao pensamento de Heidegger Derrida parece acenar para um resguardo, neste autor, de uma unidade comum, o autor alemão não discordaria, uma vez que o retiro do ser, sua dissimulação faria da história uma história do ser, marcada como diferença entre ser e ente. $\mathrm{O}$ esquecimento da diferença entre ser $\mathrm{e}$ ente seria ainda resguardado, considerado, nomeado. "Num texto. Sob a forma da presença. Da propriedade. Que é, ela própria, um efeito de escritura." ${ }^{653}$ Heidegger ainda resguardaria, encadearia e nomearia a diferença ontológica abrindo espaço para pensar a unidade da própria história do Ser. O que Derrida nos questiona é se seria necessário continuarmos pensando a diferença no horizonte da questão do ser. Será que não haveria outra programação? Enquanto se buscar o próprio, a unidade, a verdade e as essências, talvez se esteja caminhando para um certo enclausuramento do próprio discurso. Se reinscrevendo naquilo mesmo que tentou destruir. Este lugar da verdade, do próprio, da essência da História do ser como historia das determinações do ser dos entes incluem a relação de proximidade e questionamento do ser e do Dasein humano como um Faktum. Como vimos, a existência do Dasein mesmo é determinada a partir das possíveis determinações históricas do ser. Sua proximidade, propriedade e verdade dizem respeito à essência deste ente que nós mesmos somos. Essência esquecida e por isso tratada de modo desumano ${ }^{654}$. Ao desconstruir o sujeito, Heidegger viria recolocar, revalorizar, radicalizar o humano de modo mais essencial, mais humano. Se mantendo análogo, nessa sua 'lógica' ao que ele herda

\footnotetext{
${ }^{653}$ Derrida, A Diferença In. Margens da filosofia, 1991, p.59

${ }^{654}$ Heidegger em diálogo com Boss nos descreve acerca do pensamento hindu: "a este respeito eu acho que o homem é ser humano. No pensamento hindu trata-se de uma 'desumanização' no sentido do transformar-se do Dasein em pura iluminação.” Em outra passagem no mesmo diálogo: "a minha concepção é mais adequada [que a Hindu] uma vez que se dá a partir do Dasein e da compreensão do ser e se limita a este imediatamente experienciável." Heidegger, Seminários de Zollikon [Diálogos com Medard Boss], 2001, p.197-198.
} 
ao tentar desconstruir. ${ }^{655}$ Derrida denuncia de certo modo que Heidegger não teria escapado da linguagem que tenta desconstruir. Será que podemos pensar o humano transbordando esta proximidade-propriedade no horizonte da História do ser (se é que reconhecemos os limites deste horizonte)? Estas são algumas questões abertas por Derrida em seus textos Ousia Gramme e A diferença e Os fins do homem. É também um pouco neste sentido que Derrida nos apresenta o gesto heideggeriano como um gesto de desmetaforização (da metáfora ôntica), buscando a essência e origem da própria metáfora, pensando o ente em sua entidade, o ente na totalidade do ser. Como interpretações possíveis e históricas do ser do ente. Esta dissimulação deve ser posta a prova, deve ser confirmada e esclarecida para ser destruída e a história desta dissimulação se transformaria no próprio movimento histórico. Só escapa do presente, da presença do presente como determinação de ser, fazendo como tema esta dissimulação do sentido de ser na presença, esta dissimulação como história, de uma forma grega de dissimulação à forma pós cartesiana ${ }^{656}$, fazendo como tema as épocas da metafísica e a metafísica como época ${ }^{657}$.

É quando introduzimos as questões abertas sobre a Geschlecht de Heidegger que vamos fazer tremer ainda de maneira mais clara o repensar deste nós humanos neste autor. É talvez na busca de uma certa neutralidade deste humano com relação às dicotomias, também, sexuais, que Heidegger viria reinscrever, talvez, um outro pensamento, mais originário, mais verdadeiro, poderíamos dizer, mais humano. Nesse sentido Derrida nos questiona, qual seria o preço desta prudência? Em evitar os derivados buscando o mais original? Não seria de certo modo também este o discurso por trás de muitas linhas da psicologia, talvez possamos incluir as linhas que tem por base a analítica do Dasein, que se dizem mais verdadeiras, mais essenciais, excluindo aquelas que não são. Este discurso com base na analítica do Dasein não estaria ele reunido e inseparado de uma Geschlecht ocidental, européia, mais precisamente alemã? Em que medida ainda se pode falar do humano, de um Dasein humano, de uma Geschlecht determinada por uma Historia do ser? Como pensar a apropriação e pertença do Gedicht (poema), ou mesmo do pensar (do ser), em uma língua e em uma Geschlecht? O

\footnotetext{
${ }^{655}$ Derrida, Il faut bien manger ou le calcul du sujet In. Points de suspension. 1992, p.281-282

${ }^{656}$ Derrida, Heidegger: la question de l'Être et l'Histoire, 2013, 217-218

${ }^{657}$ Derrida, Heidegger: la question de l'Être et l'Histoire, 2013, p.228
} 
que Derrida parece sugerir seria uma suposição de Heidegger numa unidade e reunião a partir de uma Geschlecht alemã, de um alemão alto e antigo. É também este questionamento que acaba surgindo em De l'esprit: Heidegger et la question, quando Heidegger inicialmente, no começo de Ser e tempo, teria criticado e derivado a palavra espírito e depois a reinscrito num espírito mais espiritual, mais originário, num destino espiritual que vai definir o privilégio absoluto da língua alemã, e da Alemanha como centro de decisão espiritual-historial sobre a Europa (Cf. Introdução a metafísica e posteriormente apresentando o termo Geistlich com o sentido que daria Trakl (no idioma alemão) como o que traduziria mais originamente o que ele quer dizer com Geist em $O$ poema de Trakl). O que Derrida parece clamar é para que situemos este discurso heideggeriano, para reconhecermos uma certa necessidade de seu pensamento, seu caráter inaugural em tantos aspectos e sobretudo aquilo que tem de porvir para nós em seu deciframento. E acrescentamos também no que diz respeito à sua relação com a psicologia. Decifrando seu discurso, situando os riscos políticos e éticos em relação ao que nos interessa aqui, os humanos e, reconhecendo por vezes os limites desse próprio discurso. Neste sentido, vamos no próximo capítulo buscar re-pensar o que chamamos de humano a partir do pensamento de Derrida, apontando, talvez, para uma possível relação com este humano, uma possível psicologia que levaria em consideração o rastro e a diferança. 


\section{Derrida: dito humano como rastro}

\section{1}

\section{Sujeito liquidado ou prometido?}

Este talvez seja um dos textos mais importantes acerca da temática do sujeito em Derrida, na medida em que ele trata do tema e do problema do sujeito no pensamento ocidental e traz ao mesmo tempo elementos fundamentais para se pensar o que ele acredita poder responder ou se endereçar ao que chamamos sujeito. O texto intitulado "Il faut bien manger ou le calcul du sujet" (1988/1992) descreve uma entrevista com Jean-Luc Nancy onde o entrevistador traz duas questões, fórmulas, frases: 1) quem vem após o sujeito? E este "quem" apontaria para uma gramática que não estaria mais sujeita a um sujeito; 2) Um discurso predominante numa época recente, conclui a simples liquidação do sujeito.

Derrida inicia a entrevista acentuando certa precaução à respeito da doxa que comanda a formulação da própria questão. A pergunta quem viria após o sujeito supõe nela uma opinião de que haveria algo como um "sujeito" que pode ser identificado. E que poderia assim ser, talvez, liquidado. $\mathrm{O}$ autor deixa claro a confusão trazida nas perguntas, nos discursos ao pressupor que algo como um sujeito pode ser achado, determinado, analisado. Seria esta premissa óbvia? Será que podemos partir desse algo sujeito para então desenvolver os discursos? Talvez este seja um dos alargamentos, deslocamentos que Derrida nos traz para a questão do dito sujeito, do dito humano. A passagem a seguir é de extrema importância, aos poucos vamos nos aproximando dos elementos que ela nos apresenta.

Nunca houve $\mathrm{O}$ sujeito para quem quer que seja, era isso que eu queria dizer a princípio. O sujeito é uma fábula, [...] e não é para parar de o levar à sério (ele [o sujeito] é o sério mesmo) mas se interessar por aquilo que uma tal fábula supõe de discurso e de ficção consensual. ${ }^{658}$

Derrida nos diz que não se vê uma liquidação, mas um retorno ao sujeito e do sujeito. O sujeito teria sido reinterpretado, restaurado, reinscrito mas não liquidado. Ele coloca Heidegger como um dos autores que pensaria a partir deste

\footnotetext{
${ }^{658}$ Derrida, Il faut bien manger ou le calcul du sujet In. Points de suspension. 1992, p.279
} 
retorno $^{659}$ e que junto a eles, os demais autores que não vamos nos aprofundar aqui, teriam acreditado ter deixado o sujeito para trás, efeito de uma doxa comum $^{660}$ entre os pensadores citados. O que Derrida sugere é que Heidegger teria pensado ter deixado o sujeito para trás, uma vez que o Dasein não seria o mesmo que sujeito. Segundo o autor franco-magrebino, após o Dasein heideggeriano o sujeito não teria sido deixado para trás, nem liquidado, como eles pensavam, mas teria sido reinscrito e reinterpretado. Re-marcado. Em outro lugar ele aponta esta estrutura de reinscrição do sujeito e da identidade: "uma identidade nunca é dada, recebida ou alcançada, não, apenas existe o processo interminável, indefinidamente fantasmático, da identificação." 661 Identidade assombrando identidade, eu assombrando eu. No meu caso, por exemplo, poderíamos, talvez dizer que uma Débora me assombra? Como um fantasma cuja relação não pode ser de apropriação, aproximação, uma vez que não se apropria de um fantasma, de uma assombração. Esta relação tampouco pode ser de completa distancia, não se tem controle sobre as assombrações, sobre quem o(s) fantasma(s) virá(o) assombrar. O plural pressuporia que não existe um fantasma, mas fantasma de fantasma de fantasma, espectro de espectro de espectro. Estrutura espectral do rastro que viemos tentando descrever e que agora relacionamos mais diretamente à temática do dito humano.

A entrevista se encaminha na direção da ligação entre o quem e o sujeito. Em que medida o quem guarda algo do sujeito? Ou como o quem responde ou é respondido por um sujeito? E ainda, como podemos pensar esta relação? Como Derrida desloca ou alarga esta relação? Ele (o quem) poderia já estar lá antes da pergunta (pelo quem), seria assim, sugere Derrida, que Heidegger teria identificado o Dasein. Mas haveria uma possibilidade que o autor considera mais interessante ${ }^{662}$, ela (a possibilidade) superaria a própria questão, a reinscrevendo na experiência de uma "afirmação" de um "sim" ou de um "engajar" (engage Zusage), palavra emprestada de Heidegger ${ }^{663}$ esta palavra diria respeito a certa

\footnotetext{
${ }^{659}$ Derrida, Il faut bien manger ou le calcul du sujet In. Points de suspension. 1992, p. 271

${ }^{660}$ Derrida, Il faut bien manger ou le calcul du sujet In. Points de suspension. 1992, p.272

${ }^{661}$ Derrida, O monolinguismo do outro ou a prótese de origem, 2001, p.43

${ }^{662}$ Derrida, Il faut bien manger ou le calcul du sujet In. Points de suspension. 1992, p.275

${ }^{663}$ Em De l'esprit: Heidegger et la question, 1987, p.147-154, Derrida numa grande nota desenvolve a partir do Zusage de Heidegger esta aquiescência primeira, anterior à linguagem, à pergunta. Relacionada à promessa, a missão historial em Heidegger, esta aquiescência, engajamento acenaria para Derrida à possibilidade de um pensar que precede e excede o questionamento e que seria da ordem de uma afirmação, abertura, à um sim primeiro, a uma
} 
aquiescência à linguagem como escritura, à marca, que supõe a questão mesma. Seria da ordem de um sim sim que responderia antes mesmo de poder formar uma questão. Seria, talvez, da ordem de uma responsividade. Como Derrida nos descreve em outro lugar, esta seria da ordem de uma intimação à resposta, uma predisposição a dizer sim, como falamos em inglês a responsiveness, responsividade ${ }^{664}$. "A relação a si nesta situação [de responsividade] só poderia ser [da "ordem"] da diferança, ou seja, da alteridade ou do rastro." ${ }^{\text {"65 }}$ E fica claro como Derrida acentua este lugar do quem, como um lugar que não é um lugar, uma vez que não é localizável ao mesmo tempo necessário e inencontrável, necessário e impossível (inencontrável). Acenaria mais para uma instância sem estância, de um sem, mas sem negatividade, para um quem assediado pela problemática do rastro e da diferança, da afirmação, da assinatura, do dito nome próprio, do jet (lançado) (antes de todo subjet, objet, projet) como destinerrância dos envios ${ }^{666}$. Cada elemento trazido nesta passagem será mais bem compreendido neste capítulo.

Derrida descreve o que chamamos de sujeito a partir de uma outra possibilidade, como vimos, a partir da problemática da diferança e do rastro. $\mathrm{Ou}$ seja, da não origem e do não telos, do não lugar como algo que não pode ser encontrado, mas que acena para uma instância. Instância de lançamentos (jet) e desvios, envios destinerrantes, destinos errantes não determinados de forma clara, sem endereço certo, destinos que se destinam mas que não tiveram origem e, por isso não sabem para onde ir. Aquiescente à linguagem, ao rastro, aos envios herdados. Respostas, afirmação primeira, anterior à própria questão. Sim antes de qualquer sim ou não, antes de qualquer pergunta. Seria a partir de uma "afirmação deslocada (portanto sem "firmeza" nem "fechamento") que algo como o sujeito, o homem ou quem que seja pode tomar forma."

resposta e responsabilidade, talvez, de outra ordem. Não vamos desenvolver aqui como o termo Zusage aparece no pensamento heideggeriano, mas sobretudo, como ele se desenvolve após ter sido tomado emprestado por Derrida. Pensando sua relação com o dito humano, a dita subjetividade. Para esta relação Derrida - Zusage heideggeriano veja também Derrida, A number of Yes, In. Psyché: Inventions of the other II, 1987/2008 pp.231-240.

${ }^{664}$ Derrida, Le survivant, le sursis, le sursaut, In. Penser à ne pas voir. 2014, p.366 (publicado originalmente em La Quinzaine littéraire, n882, 2004)

${ }^{665}$ Derrida, Il faut bien manger ou le calcul du sujet In. Points de suspension. 1992, p. 275

${ }^{666}$ Derrida, Il faut bien manger ou le calcul du sujet In. Points de suspension. 1992, p. 275

${ }^{667}$ Derrida, Il faut bien manger ou le calcul du sujet In. Points de suspension. 1992, p. 276 
O que está em jogo nesta instância não seria da ordem da presença ou da identidade a si. Não é algo como uma identidade ou unidade. Mas uma singularidade que se "desloca ou se divide ao reunir para responder ao outro, cujo chamado precede de alguma forma sua própria identificação a si, pois a este chamado eu não posso não responder, ter já respondido, mesmo acreditando que estou respondendo não." ${ }^{668}$ A singularidade de algo como o sujeito ou mesmo a filosofia, a psicologia, poderíamos dizer também o dito eu não teria seu domínio e seus limites dados aprioristicamente. Desta forma, quando Derrida nos descreve em Passages - du traumatisme à promesse (1990) que por este motivo a filosofia seria sempre chamada a transgredir suas fronteiras, limites e sua própria destinação $^{669}$, transgredir sua destinação. É possível re-pensar o mesmo para o dito sujeito? Não estaria ele, o sujeito, sua singularidade, ou mesmo minha singularidade, chamada a transgredir seus, meus, próprios limites, minha própria destinação? O limite da filosofia e talvez, do sujeito, está sempre em jogo (jet), sendo ultrapassado, alargado, desconstruído, solicitado, tremido, deslocado. Esta solicitação, substituição, suplementação, transgressora, caminharia junto à singularidade da resposta do chamado que é sempre do outro.

Esta relação transgressão e singularidade é de outra forma trabalhada nesta mesma entrevista Passages - du Traumatisme à la promesse, onde Derrida nos descreve que uma data marcaria uma singularidade, um aqui temporal e espacial, certa unicidade insubstituível que nós queremos, de algum modo manter, guardar $^{670}$, determinar. A data seria aquilo que se inscreve para manter a unicidade, mas que ao mesmo tempo a perde. O mesmo ele diria do nome, do nomear. "O nome é a denominação de uma singularidade, mas também na sua possibilidade de repetir este nome, esta denominação é o apagamento desta singularidade." ${ }^{\prime 671}$ Não seria também isso que ele nos descreve quando diz em Survivre que

eu parto de aqui: nenhum sentido se determina fora do contexto mas nenhum contexto dá lugar à saturação. Eu não faço disso uma questão de riqueza substancial, de recurso semântico, mas de estrutura, a estrutura do resto e da

\footnotetext{
${ }^{668}$ Derrida, Il faut bien manger ou le calcul du sujet In. Points de suspension. 1992, p.276

${ }^{669}$ Derrida, Passages - du Traumatisme à la promesse In. Points de suspension. 1992, p.389

${ }^{670}$ Derrida, Passages - du Traumatisme à la promesse In. Points de suspension. 1992, p.391

${ }^{671}$ Derrida, Passages - du Traumatisme à la promesse In. Points de suspension. 1992, p.403
} 
iteração $^{672}$. Mas eu dei a ela muitos outros nomes e, precisamente, tudo se encaixa aqui no aspecto secundário da nominação. A nominação importa mais para ser constantemente conduzida em um processo que ela não domina. ${ }^{673}$

Um nome ou mesmo uma data são determinados, repetidos e acabam perdendo a singularidade que queriam guardar. A experiência de guardar a singularidade ao mesmo tempo a violenta e a perde, a apaga. Transborda e apaga. Falamos disso antes. Existiria uma experiência traumática na singularidade, ela anda de traumatismo em traumatismo, de violência em violência, poderíamos dizer. Uma vez que ela se transborda, se apaga, se substitui, se suplementa, se desloca, se alarga, resta [estrutura do resto] e jamais se apropria de si, tenta se saturar, se unificar ou se completar como uma identidade a si, uma presença a si, mas nunca consegue ter sucesso. E por isso Derrida nos diz, que "um discurso filosófico [podemos pensar, um discurso psicológico] que não seria provocado ou interrompido pela violência do chamado do outro, de uma experiência não dominável, não seria um discurso filosófico muito questionador, muito interessante." ${ }^{674}$ Talvez, falar da singularidade de algo seria justamente trabalhar em cima deste alargamento, desta provocação, o que estamos fazendo um pouco com os textos heideggerianos a partir da temática do humano, do sujeito, onde cada elemento dessa frase seria de algum modo alargado e, com isso, a singularidade deles trabalhada. Se o humano não fosse mais deslocado, alargado, re-pensado, re-marcado, não haveria nada mais a dizer sobre ele, não haveria mais singularidade como singularidade de singularidade, sujeito de sujeito. Trazer a temática do sujeito é dar voz a um discurso que hoje é ainda preponderante e fundamental. O que Derrida sugere quando Nancy o questiona acerca de Auschwitz, por exemplo, na entrevista que estamos desdobrando Il faut bien manger ou le calcul du sujet, é justamente não pensar que uma condenação acerca disso ou daquilo seria suficiente, há uma compulsão pelo discurso sentencioso, a querer acusar, dar lições ${ }^{675}$, sentenciar/parar (arrête) ${ }^{676}$. Mas ao sentenciar estaríamos respondendo totalmente, justamente à altura da singularidade deste

\footnotetext{
${ }^{672}$ Em Derrida, como pudemos ver existe certo retorno, não de um mesmo, uma repetibilidade e iterabilidade, que re-marca, re-pensa, re-passa, no re- de um retorno afirmativo no engajamento do sim sim

${ }^{673}$ Derrida, Survivre, In. Parages, 1979/1986, p.125

${ }^{674}$ Derrida, Passages - du Traumatisme à la promesse In. Points de suspension. 1992, p.395

${ }^{675}$ Derrida, Il faut bien manger ou le calcul du sujet In. Points de suspension. 1992, p.301

${ }^{676}$ Derrida em seu texto Survivre (1979/1986) desenvolve e desdobra a relação entre sentença, parada (arrête) aresta e borda (arête).
} 
acontecimento? Discursar sobre Auschwitz, por exemplo, ele nos diz, é admitir que a coisa ainda não foi pensada, que ainda não temos um discurso a sua medida ${ }^{677}$. Trabalhar, discursar, pensar sobre isso, talvez indefinidamente, é deixar que ele fale por si, pelos seus referentes, pela memória e porvir deste acontecimento.

Será que podemos re-pensar dessa forma sobre o dito humano? Não seria este o movimento desconstrutivo? Desequilibrando, re-marcando, re-pensando o dito humano. Não há última palavra sobre isso, se não eu nem poderia estar trabalhando sobre ele nesta pesquisa ou mesmo na prática clínica. Tampouco poderíamos estar debatendo o que chamamos de humano, seus referentes, sua memória e seu porvir. Não é este também um trabalho na clínica? Pensar e repensar, re-marcar, discursos sobre aquele que fala sobre um si que é si de si, que não se fecha numa unidade, mas está indefinidamente remarcando aquilo que não podemos mais chamar de si. Talvez, nestas re-marcas, neste re-pensar, neste trabalho desconstrutivo, e aqui aceno para esta possibilidade na clínica, possamos trabalhar de forma menos sentenciosa, menos enclausurada, trabalhando e desequilibrando os limites que antes traziam dor e sofrimento para aquele que procura ajuda, por exemplo. Não sei se conseguiremos voltar a este fio neste presente texto.

Esta responsividade primeira sobre a qual falamos, talvez vá de encontro à exemplaridade heideggeriana do Dasein como ente questionante. Vimos que este privilégio do Dasein como o único ente que pode questionar, e que por isso possui uma relação com o ser do ente, é acentuada por Derrida em alguns de seus textos. Mas justamente nesta entrevista o autor parece apontar para outra possibilidade do dito sujeito. Segundo Derrida, ele já havia tentado nos mostrar as pressuposições desta exemplaridade e aqui ele a retoma, acenando certa herança do autor alemão no que diz respeito ao ponto de partida escolhido, a exemplaridade do Dasein para a leitura do sentido do ser, o nós entes questionantes, nós abertos ao ser que temos uma relação de presença ou de proximidade a si. Derrida tenta nos mostrar que de algum modo Heidegger ainda herdaria aquilo que tenta destruir ${ }^{678}$ relacionando-o

\footnotetext{
${ }^{677}$ Derrida, Il faut bien manger ou le calcul du sujet In. Points de suspension. 1992, p.301

${ }^{678}$ Derrida, Il faut bien manger ou le calcul du sujet In. Points de suspension. 1992, p.281-282
} 
à axiomática do sujeito ${ }^{679}$. Ao deslocar a pressuposição da questão no pensamento heideggeriano, Derrida aponta para uma relação com o sim sim, com a afirmação, com o Zusage (engajamento, aquiescência) para se pensar o dito sujeito.

Para falar deste dito sujeito, o autor recorre ao que ele chama de pensamento da destinerrância, da destinação, mas que não é restrito ao sujeito. O rastro e o que ele chama de expropriação, uma reapropriação que nunca se apropria e por isso, expropria, não se estabilizaria na forma de um sujeito ${ }^{680}$. Não há estabilidade nem descanso na desconstrução. Em nome de um universal (em Heidegger no que diz respeito à temática do humano seria talvez a relação exemplar-próxima-própria do Dasein com o ser do ente) se estabelece algo impossível de se universalizar no humano, mas que o pensamento tradicional acaba por recair. Falar de um sujeito pressuporia uma presença, uma substância, estância, é a partir de certo fechamento da identidade a si, de uma estrutura ainda muito estreita de identificação a si que se confere ainda hoje ao conceito de sujeito seu efeito dogmático $^{681}$. Mas como já vimos o pensamento de Derrida vai em direção ao rastro, à instância, à não totalização, ao não elementar, não originário, não pureza, não presença. Em suma, ao outro como aquilo que não posso me apropriar, conhecer, compreender. Não é a sugestão de um pensamento caótico, pelo contrário. É justamente por ser instável, pela impossibilidade de totalização, que ela é constantemente requerida como praça forte, como estabilização, reunião, presença, como vimos, há desejo de presença. Desejo de pureza, de identidade a si, de apropriação. O próprio Derrida em seu texto $O$ monolinguismo do outro ou a prótese de origem (1996) após confessar que sempre só admirou o francês (idioma) puro, nos descreve que "o primeiro movimento do que se chama a desconstrução encaminha-a para esta crítica do fantasma ou do axioma da pureza

\footnotetext{
${ }^{679}$ Em Il faut bien manger ou le calcul du sujet In. Points de suspension. 1992, p.281 Derrida aponta para os fios condutores no desenvolvimento da conferência De l'esprit: Heidegger et la question (1987) pp.24-30: questão da questão (questionar o privilégio da questão no caminho do pensamento, sendo o Geist, talvez esta possibilidade inquestionada da pergunta), da técnica (tentativa, talvez de evitar certa contaminação, destituição, pensando o Geist como o que salva, a pureza, mas também o mal) da animalidade (animal não questiona, não tem Geist? Pobre de Geist?) e da epocalidade (discriminação epocal ordenada entre o geistig, o espiritual derivado platônico, cristão, metafísico e o pensamento espiritual (geitsliche) que inclui o Gespräch com Trakl. Nós não vamos desenvolver estes fios trazidos por Derrida e relacionados à temática do Geist.

${ }^{680}$ Derrida, Il faut bien manger ou le calcul du sujet In. Points de suspension. 1992, p.283 e 285.

${ }^{681}$ Derrida, Il faut bien manger ou le calcul du sujet In. Points de suspension. 1992, p.287
} 
ou para a decomposição analítica de um purificação que reconduziria à simplicidade indecomponível da origem." 682

Um pensamento do entre, do intervalo, do talvez, do quase e por isso ele nos diz que "entre o lançar e a queda (Verfallen) há também um lugar de passagem possível. ${ }^{, 683} \mathrm{O}$ que o autor chama de expropriação não seria da ordem de uma ausência ou de uma negatividade, mas suporia a irredutibilidade da relação com o outro, qualquer radicalmente outro é qualquer radicalmente outro, o chamado anterior a própria resposta. É um pensamento que resistiria a toda forma de subjetivação, mas reconhece o desejo de subjetivação. A passagem a seguir talvez nos esclareça um pouco mais acerca do pensamento da desconstrução do que se toma por sujeito. O caminho que Derrida sugere vai nesta direção:

não se trata de uma posição a essa enorme multiplicidade de discursos tradicionais sobre o homem, o animal, a planta ou a pedra, um outro discurso sobre as mesmas "coisas", mas de analisar incansavelmente e pelos seus interesses, toda a maquinária conceitual que nos permitiu falar de sujeito até agora. E a análise produz sempre mais, algo que não é apenas uma análise. Ela transforma - ou traduz uma transformação já em curso. A tradução é transformativa. Isso explica o nervosismo ou a crispação daqueles que desejam manter todos esses temas, todas essas "palavras" (homem, sujeito etc) ao abrigo de todo questionamento e que manipulam uma suspeita ético-política em relação à desconstrução. ${ }^{684}$

A desconstrução não permite repouso ou relaxamento, está sempre deslocando e alargando, traduzindo esta maquinaria conceitual que é tomada como óbvia e natural em diversos discursos. A desconstrução vem fazer tremer o que se toma por natural, por óbvio, dissimulado em discursos mais verdadeiros, mais conscientes, mais originários, mais puros, mais neutros. Quantos terríveis discursos não saíram deste lugar? E com o campo da psicologia não é diferente, ele também está sujeito aos discursos do sujeito, do dito humano reinscrito sobre formas mais "verdadeiras". Sujeito às tentativas de alcance e apreensão de um humano mais humano, mais essencial, mais próprio. E não é de certa forma este o discurso que enclausura em si mesmo as diversas escolas e linhas de pesquisa na área da psicologia, da filosofia e nas ciências humanas? E não é este mesmo discurso que estaria por traz das falas racistas ou homofóbicas, reducionistas em muitos sentidos? Ainda hoje surgem pessoas que buscaram ajuda com psicólogos

\footnotetext{
${ }^{682}$ Derrida, O monolinguismo do outro ou a prótese de origem, 2001, p.64

${ }^{683}$ Derrida, Il faut bien manger ou le calcul du sujet In. Points de suspension. 1992, p.285

${ }^{684}$ Derrida, Il faut bien manger ou le calcul du sujet In. Points de suspension. 1992, p.288 (Grifado nosso)
} 
que sugeriram a cura gay. Sem falar naqueles, em nós muitas vezes que discursamos falas racistas, homofóbicas, machistas herdadas de discursos que se dizem mais originários e que não são analisados ou desconstruídos por nós, por aqueles que lidam e que pensam o dito humano. Neste sentido Derrida aponta para este "lugar":

aí onde a propriedade natural não existe, nem o direito de propriedade em geral, aí onde se reconhece esta des-apropriação [ex-apropriação], é possível e torna-se mais necessário do que nunca identificar, às vezes para os combater, movimentos, fantasmas, "ideologias", "fetichizações" e simbólicas da apropriação. Uma tal advertência permite ao mesmo tempo analisar os fenômenos históricos de apropriação e de os tratar politicamente, evitando em particular a reconstituição do que estes fantasmas puderam motivar: agressões "nacionalistas" (sempre mais ou menos "naturalistas") ou homo-hegemonias monoculturalista. ${ }^{685}$

A irredutibilidade do outro em toda relação é o que vai preceder e pressupor como chamado antes de qualquer questão, inviabilizando qualquer fechamento, totalização ou mesmo a possibilidade do aparecimento do como tal. Uma vez que o quem do outro jamais poderia aparecer absolutamente como tal sem desaparecer como outro ${ }^{686}$. Como vimos, a nominação ou o aparecimento do como tal, por exemplo, apagam o outro como outro. O chamado não é do ser e nem tem origem, ele viria de parte alguma localizável. É o chamado do outro e está sempre instituindo, intimando, respostas, um chamado para o qual não posso não responder, estaria na raiz de toda responsabilidade. Este pensamento fala daquilo que não se pode, não se consegue e não se deve submeter o outro em geral. E por isso, Derrida nos diria que algo do incalculável e do indecidível estaria sempre em jogo nesta relação do quem, por exemplo. Se para Heidegger o mais digno da humanidade do homem é que ela seja humana e não inumana, como vimos em carta Sobre o humanismo. Para Derrida 'talvez seja mais 'digno' da humanidade manter alguma inumanidade." ${ }^{687}$ Algo do outro, do não reapropriável, não subjetivável, que não é passível de ser identificado, mantém o outro como outro, "chamado singular à resposta ou a responsabilidade." ${ }^{688}$ Haveria um apelo, um chamado à resistir a reapropriação do outro, disso que não se deixa apropriar, mas que se deseja. Esta resistência é também responsabilidade. Não uma responsabilidade de si ou de algo, mas disso que não sabemos determinar, que

\footnotetext{
${ }^{685}$ Derrida, O monolinguismo do outro ou a prótese de origem, 2001, p.96

${ }^{686}$ Derrida, Il faut bien manger ou le calcul du sujet In. Points de suspension. 1992, p.289

${ }^{687}$ Derrida, Il faut bien manger ou le calcul du sujet In. Points de suspension. 1992, p.290

${ }^{688}$ Derrida, Il faut bien manger ou le calcul du sujet In. Points de suspension. 1992, p.290-291
} 
resiste a determinação e que está sempre em jogo na determinação de "algo" como o sujeito, o humano ou de "algo" como o que podemos desdobrar sobre nós mesmos.

O quem para Derrida não estaria, deste modo, restrito a gramática da língua francesa, nem ocidental. Mas acenaria para o pensamento da expropriação, do rastro, da diferança. Este pensamento requer o que o autor chama de sacrificar o sacrifício. É justamente isto que Heidegger, segundo Derrida, não faria ${ }^{689}$. A estrutura sacrificial acena para a estrutura carno-falogocêntrica, certa virilidade carnívora inerente ao discurso do sujeito. A força viril do macho, adulto, pai, marido, irmão, aqui poderíamos acrescentar branco, europeu, ocidental, rico, belo, consciente dominaria o conceito de sujeito. Por que algumas mulheres quebram as pernas e enxertam "ossos" para ficarem mais altas, ou realizam cirurgias para alterar o formato dos olhos (mais comum entre as orientais)? Ou por que tantas mulheres com anorexia e bulimia? Quantos negros ou índios numa universidade? Com direito à saúde, educação? Terapia? Por que a sede da ONU (Organização das Nações Unidas) fica em Nova York? Ou ainda por que a OEA (Organização dos Estados Americanos) que tem um dos seus principais pilares os direitos humanos, tem a principal sede em Washington? De que humano discursamos? Quem é o humano que chamamos humano? O dito humano. Esta é uma das análises da maquinária conceitual que Derrida nos chama a atenção.

Houve, há ainda, na espécie humana, muitos 'sujeitos' que não são reconhecidos como sujeitos, e recebem esse tratamento do animal [um animal pode sofrer e não será, em sentido próprio um sujeito lesado. O que chamamos de animal não é considerado um sujeito da lei ou do direito]. ${ }^{690}$

Este dito humano viril aceita o sacrifício e come a carne ${ }^{691}$. Um chefe deve ser comedor de carne neste esquema dominante, não só politico, moral, intelectual, mas da própria subjetividade. "O sacrifício carnívoro é essencial para a estrutura da subjetividade." ${ }^{, 62} \mathrm{O}$ que está em jogo nesta estrutura sacrificial, falogocêntrica é a apropriação assimilação do outro, comer interiorizar, se reapropriar do outro, interiorizá-lo. Falamos um pouco sobre isso no texto Timpanizar a filosofia, este seria o esquema dominante.

\footnotetext{
${ }^{689}$ Derrida, Il faut bien manger ou le calcul du sujet In. Points de suspension. 1992, p.294 (Vamos desdobrar em seguida o que Derrida tentou acenar com este não sacrifício de Heidegger).

${ }^{690}$ Derrida, Força de lei: o fundamento místico da autoridade, 2007, p.34

${ }^{691}$ Derrida, Il faut bien manger ou le calcul du sujet In. Points de suspension. 1992, p.295

${ }^{692}$ Derrida, Força de lei: o fundamento místico da autoridade. 2007, p.35.
} 
Para tudo que acontece na borda dos orifícios [...] a metonímia do 'comer bem' será sempre a regra. A questão não é mais saber se é 'bom' comer o outro ou se o outro é 'bom' de 'comer', ou de saber qual é o outro. Um come o outro de qualquer forma e nos deixamos ser comidos pelo outro. ${ }^{693}$

Nesta estrutura onde um come o outro, estrutura de substituições, de suplementos, um vem se construir no melhor modo, no mais respeitável, mais elevado, mais digno, mais verdadeiro, excluindo outros, esta é também a estrutura sacrificial que Derrida nos chama a atenção. Estrutura que Heidegger não sacrificaria na medida em que, como suposto mestre que come a carne, ele vem comer (apropriar) sacrificando a carne que existia, no caso aqui se apropria do sujeito, come e sacrifica, reinscrevendo um humano mais humano. Ou seja, ele reinscreve, repensa a essência do humano, de um humano mais humano do que o humano que havia antes, em que para ser mais humano o que está em jogo é a relação com o Ser, acenando para uma humanidade mais digna, onde a essência do homem seria levada mais em conta, como essência de abertura ao ser. Um discurso que ainda acenaria para uma verdade, para o mais originário, um originário, por vezes grego, por vezes alemão. Dessa forma, fica mais claro quando Derrida nos descreve que Heidegger não sacrificaria o sacrifício.

Se estamos nessa estrutura sacrificial, falogocêntrica onde se come, onde deve se comer. Como comer? Como se deve comer bem? Talvez, não comer bem "apenas para mim, para um eu, que, dados seus limites, comeria mal, ela deve ser repartida [...] aprender a dar de comer, aprender-a-dar-de-comer-ao-outro. Jamais se come só, esta é a regra do 'deve-se comer bem'. É uma lei de hospitalidade infinita. ${ }^{, 694}$ Eu como outro que come o outro que come o outro .... Qualquer que seja o direcionamento ao outro estaria ligado a uma apropriação identificadora, uma compreensão fracassada e desejada. Necessário impossível ${ }^{695}$. Não se foge

\footnotetext{
${ }^{693}$ Derrida, Il faut bien manger ou le calcul du sujet In. Points de suspension. 1992, p.296

${ }^{694}$ Derrida, Il faut bien manger ou le calcul du sujet In. Points de suspension. 1992, p.296-297

${ }^{695} \mathrm{O}$ necessário impossível é muito bem descrito na passagem a seguir sobre a performance babélica. "No instante mesmo em que pronunciando Babel experimentamos a impossibilidade de decidir se esse nome pertence, propriamente e simplesmente, a uma língua. E o que importa é que essa indecidibilidade elabore uma luta pelo nome próprio no interior de uma cena de dívida genealógica. Procurando "se fazer um nome", fundar ao mesmo tempo uma língua universal e uma genealogia única, os Semitas querem colocar a razão no mundo, e essa razão pode significar simultaneamente uma violência colonial (pois eles universalizam assim seu idioma) e uma transparência pacífica da comunidade humana. Inversamente, quando Deus lhes impões e opõe seu nome, ele rompe a transparência racional, mas interrompe também a violência colonial ou o imperialismo linguistico. Ele os destina à tradução, ele os sujeita à lei de uma tradução necessária e impossível; por conseguinte, do seu nome próprio traduzível-intraduzível, ele libera uma razão universal (esta não será mais submetida ao império de uma nação particular),
} 
dessa lei de hospitalidade, de comilança conjunta, repartida do comer bem, onde até o Bem come também e é comido, talvez, pelo mais digno ou pelo mais forte, mas que por sua vez também são comidos. Esta é também a estrutura violenta da escritura, da diferança que abordamos em outro momento. Ao comer o outro, do outro, há violência.

É no chamado do outro que se resiste, talvez, se desconstrua esta estrutura falogocêntrica ${ }^{696}$. Sacrificando o sacrifício. Resistir ou quase-resistir, não totalmente, à estrutura sacrificial. O deslocamento e alargamento característico do pensamento derridiano vai desdobrar esta estrutura em sua forma suplementar, deslocando, alargando justamente os limites oposicionais lineares, indivisíveis relativos ao pensamento sobre o dito humano. E por isso, ele nos fala muito do limite homem - animal. Mas também adulto-criança, homem-mulher, ocidenteoriente, e por que não podemos pensar o limite entre sanidade e loucura? Onde o são, o normal também está assegurado por margens que talvez não sejam muito naturais, não sejam óbvias, nem verdadeiras.

Em Passages - du Traumatisme à la promesse Derrida nos descreve que seria a monstruosidade que daria a consciência da própria norma, do dito normal e de sua história. As normas têm história, Heidegger mesmo já havia acenado para isso. O monstro, a monstruosidade que descreve Derrida, falaria daquilo que não tem nome, mas que nem por isso é anormal. Ele se mostra. O monstro se mostra. Em La main de Heidegger, Derrida já havia trabalhado em cima da relação monstre-montre: monstro-mostrar. O monstro aterroriza, pois não sabemos como identificá-lo, uma vez que não haveria antecipação alguma para encontrá-lo e fazer com que ele possa se mostrar como figura identificável. Submisso à mesma lei da data e do nome, o monstro ao se mostrar começa a ser domesticado, interiorizado, comido, assimilado, apropriado. Deixando de ser monstro. Perdendo sua singularidade monstruosa. Talvez, neste sentido, toda singularidade inicialmente seja monstruosa. Singularidade que se perde ao nomearmos, datarmos e repetirmos. Monstruosidade singular que se perde ao ser domesticada,

mas ele limita por isso a universalidade mesma: transparência proibida, univocidade impossível. A tradução torna-se a lei, o dever e a dívida, mas dívida que não se pode mais quitar. Tal insolubilidade encontra-se marcada diretamente no nome de Babel: que ao mesmo tempo se traduz e não se traduz, pertence sem pertencer a uma língua e endivida-se junto dele mesmo de uma dívida insolvente, ao lado dele mesmo como outro. Tal seria a performance babélica.” Derrida, Torres de Babel, 2002. p.25-26 (Grifado nosso)

${ }^{696}$ Derrida, Il faut bien manger ou le calcul du sujet In. Points de suspension. 1992, p.298 
identificada, percebida, compreendida. "Começamos a repetir este traumatismo que é a percepção do monstro" ${ }^{\text {697 }}$. Estrutura da hospitalidade, o fazemos entrar em nossa casa, tomar nossos hábitos e o domesticar. Quando menos esperamos, o monstro deixou de se mostrar.

Ainda sobre os limites do sujeito, no sujeito, o que está em jogo, Derrida nos adverte, é justamente o fato de que "nunca soubemos como cortar um sujeito." ${ }^{698}$ Nunca soubemos e, talvez não saberemos, se os cortes que damos no que entendemos por ele, são precisos. E se Derrida nos fala de temas atuais, como ele mesmo sublinha, à respeito do corte na política dos vivos, vida e morte, por exemplo, ou mesmo os cortes já mencionados, humano-inumano, homem-mulher, criança-adulto .... Um corte entre a loucura e a sanidade seria talvez muito problemático. Corte este que é re-cortado diversas vezes. A responsabilidade mesma estaria pautada tradicionalmente por estes cortes realizados. A responsabilidade para a qual aponta Derrida não segue uma medida, não é calculável e não se rege pelas oposições que surgem da boa comilança, este é o sonho de toda boa consciência. E não é também a partir dessa estrutura que muitos discursos terapêuticos e psicológicos surgem? A responsabilidade acenada por Derrida é da ordem do excesso e da desmedida, da surpresa e do não localizável, da diferança, da desconstrução e do rastro. Reger a responsabilidade no sujeito, no homem ou mesmo no Dasein seria ainda reger-se sobre medidas nomeáveis, determinadas de algum modo.

A inscrição do dito sujeito atentando para o rastro, resistindo ao cálculo e ao desejo de presença, de origem, desejo da boa comilança como da boa consciência seria, talvez, o compartilhamento de um não saber que não pode ser alcançado, mas, todavia, prometido. O desejo de presença é inscrito na estrutura da promessa como estrutura da própria linguagem como escritura. Falar ao outro é de algum modo estar engajado a ir ao final da frase, por exemplo, é estar submetido a um chamado do outro. "Antes mesmo de decidir aquilo que vou dizer, eu prometo the dizer, eu respondo à promessa de falar, eu respondo." ${ }^{699}$ Responder é estar engajado neste chamado do outro, ao outro; que não tem nome, que não é possível controlar, calcular, medir, presentificar, determinar, mas que vem a mim. Se

\footnotetext{
${ }^{697}$ Derrida, Passages - du Traumatisme à la promesse In. Points de suspension. 1992, p.400

${ }^{698}$ Derrida, Il faut bien manger ou le calcul du sujet In. Points de suspension. 1992, p.299

${ }^{699}$ Derrida, Passages - du Traumatisme à la promesse In. Points de suspension. 1992, p.398
} 
destina a mim. De um lugar inencontrável e se destina para outro lugar surpreendente, na dinâmica do porvir. Neste sentido, a linguagem (do outro) é mais velha do que eu ${ }^{700}$. Dizer sim é prometer. Promessa de confirmar o sim que foi dito. Esta estrutura do sim, do engajamento, do endereçamento, do envio e da destinação que Derrida apontou como sendo outra forma de inscrever, de falar do dito sujeito é também a estrutura da promessa, do sujeito prometido. Prometo, desejo determiná-lo, alcançá-lo, me apropriar dele. Ao mesmo tempo, prometo me determinar, e assim, me re-inscrevo, me re-penso. Mas seria este discurso da determinação, da apropriação, do sacrifício, responsável para com a temática do dito sujeito?

É aí que sou responsável, antes mesmo de escolher minha responsabilidade. A responsabilidade de inscrever, segundo Derrida, não seria da ordem da escolha de algo em prol de outro, nem da liberdade de escolha. Isto seria cálculo. Dinâmica econômica dos cortes. Querendo ou não, somos responsáveis na medida em que respondemos e prometemos. Respondemos ao outro, ao chamado do outro, à destinação, ao endereçamento e à promessa que o outro também fez. Respondemos indefinidamente e, por isso, a desconstrução não tem repouso e é da “ordem” da afirmação.

Para compreendermos melhor a relação entre promessa, sim sim e resposta vamos recorrer ao texto Nombre de oui (1987) em que Derrida nos descreve esta relação, mostrando que a problemática da questão como apriorística no pensamento tradicional seria posterior ao engajamento do sim. Este sim sobre o qual nos descreve o autor, fala de uma afirmação primeira anterior à possibilidade de qualquer questão. Este archi-originário sim não descreveria um estado de algo, mas o engajamento, aliança ou promessa anterior a qualquer ontologia ou estado transcendental. Este sim permanece quase no começo, não se deixando reduzir. Supondo que exista um primeiro sim que promete e engaja antes de qualquer coisa, este primeiro sim suposto teria, por um lado, como estrutura uma resposta, esta já seria o segundo primeiro sim que viria depois de uma demanda, uma questão ou outro sim. Por outro lado, sendo um engajamento ou promess, deveria ele estar atrelado à confirmação de um outro [próximo] sim. Um sim para outro [sim] que já está lá, mas ainda está por vir. Um sujeito ou um eu, por exemplo,

${ }^{700}$ Derrida, Passages - du Traumatisme à la promesse In. Points de suspension. 1992, p.398 
não estaria pressuposto neste engajamento do primeiro sim. Um eu pode dizer sim-eu somente pela promessa de manter a memória do sim e de confirmá-la. Confirmar o dizer sim - eu. A memória do dizer sim-eu e a promessa do dizer sim-eu. Promessa da memória e memória da promessa. Parece lembrar um pouco aquela brincadeira de criança do telefone sem fio, em que eu prometo manter a memória do que me foi destinado, na escuta desta memória, traduzo e transformo [tradução é transformativa ${ }^{701}$ ], reenvio. O primeiro sim não pode ter lugar sem um projeto, a promessa, a missão, envio do segundo sim que já estaria lá e o segundo sim, por sua vez, seria envelopado pelo primeiro. Tentando desdobrar esta relação do sim sim, poderíamos dizer que um sim, responde sempre à um sim anterior, mas também envia e promete à um sim porvir. De modo que, não há sim no começo, como primeiro, nem no final, mas no quase-começo e quase-fim. E o que chamamos de primeiro sim seria dobrado, duplo: sim sim assinado antecipadamente para sua própria repetição. Tal repetição condiciona a abertura de um sim e a ameaça do esquecimento. Esta memória da promessa e promessa da memória deve esquecer sua missão de e pelo sim. Prometida no primeiro, o segundo sim viria a inaugurar algo único, sob a dobra de um pretenso esquecimento. $\mathrm{O}$ segundo primeiro sim quebraria com o primeiro sim que já era duplo, dobrado, cortando, se separando para ser o primeiro, o único, abrindo por sua vez, vice versa, cada vez pela primeira vez (vices, ves, volta, fois, Mal, etc ${ }^{702}$ ). Poderíamos, talvez, dizer que o segundo sim esquece sua duplicidade para ser pretensamente único, desejo de ser um, desejo de. Em diálogo com Michel de Certeau neste texto, Derrida nos diz que o sim traria ao mesmo tempo a separação, o corte e a abertura que seriam possíveis a partir deste esquecimento, de uma memória esquecida. Um sim não poderia desta forma ser contado ou calculado. Promessa, missão, emissão, sempre se envia em número. ${ }^{703}$ Para continuarmos desdobrando o texto e entrarmos na temática da responsabilidade, esta passagem a seguir, retirada do debate em que participou Derrida na Universidade de Villanova, Pensilvânia, nos esclarece acerca do sim sim.

Desconstrução é "sim", está ligada ao "sim", é uma afirmação. [...] Quando você diz "sim", isso implica que no momento seguinte você terá que confirmar o "sim"

\footnotetext{
${ }^{701}$ Derrida, Il faut bien manger ou le calcul du sujet In. Points de suspension. 1992, p.288

${ }^{702}$ Derrida acena para esta cadeia semântica, decidimos mantê-la apontando o caráter duplo, a volta, dobra característica do sim sim. Derrida, A number of Yes, In. Psyché: Inventions of the other II, 2008, p.240

${ }^{703}$ Derrida, A number of Yes, In. Psyché: Inventions of the other II, 2008, p.240,
} 
pelo segundo "sim". Quando eu digo "sim", eu imediatamente digo "sim, sim." Eu me comprometo comigo mesmo de confirmar meu comprometimento no próximo segundo, e depois amanhã, e depois de amanhã. Isso significa que o "sim" imediatamente se duplica, duplica ele mesmo. Você não pode dizer "sim" sem dizer "sim, sim." Isso implica a memória naquela promessa. Eu prometo manter a memória do primeiro "sim". Num casamento, por exemplo, ou numa promessa, quando você diz "sim, eu aceito," "eu aceitarei”, isso implica "eu irei dizer sim 'aceitarei' amanhã," e "eu irei confirmar minha promessa"; senão não há promessa. Isso significa que o "sim" mantém antecipadamente a memória do próprio começo, e esta é a maneira que a tradição acontece. ${ }^{704}$

\section{2 \\ Responsabilidade e decisão}

Em sua obra Donner la mort (1992), especificamente no capítulo três da primeira parte intitulado A qui donner (savoir ne pas savoir), Derrida nos descreve em diálogo com a obra kierkegaardiana Temor e tremor acerca da responsabilidade e da decisão. Respostas singulares, como vimos, que dizem respeito à responsividade diante de um chamado, de um apelo sempre do outro como aquilo que não posso me apropriar, compreender, nomear. $\mathrm{O}$ chamado do outro é um "chamado singular à resposta ou a responsabilidade."705 Vimos que a responsabilidade para Derrida não é da ordem de um sujeito, de uma consciência, de uma unidade, nem de uma autonomia. Não é a partir de um entendimento ou compreensão, de um cálculo ou análise de variáveis possíveis, que fará com que uma pessoa responda de modo mais autônomo, consciente e responsável. A responsabilidade para o autor faz parte da dinâmica do rastro, então não tem unidade nem presença para ser autônoma ou consciente, é da ordem da surpresa e do excesso, então tampouco pode ser calculada ou planejada. Neste sentido, nos aproximamos um pouco deste texto de Derrida, com o intuito de desdobrarmos melhor como a responsabilidade e a decisão podem ser descritas pelo autor a partir da história de Abrãao trazida por Kierkegaard.

A responsabilidade como responsividade, diz respeito a esta estrutura de respostas, do sim sim, da afirmação e do engajamento diante do chamado do outro, como um "instante" de tremor. Uma vez que não se treme diante do que se sabe, se conhece e se calcula. Este diante do calculável é o que Derrida chama de

\footnotetext{
${ }^{704}$ Caputo, J. (ed.) Deconstruction in a nutshell. A conversatiom with Jacques Derrida, 1997, p. 27

${ }^{705}$ Derrida, Il faut bien manger ou le calcul du sujet In. Points de suspension. 1992, p.290-291
} 
futuro. $\mathrm{O}$ autor deixa claro a diferença entre futuro e porvir ${ }^{706}$, onde o primeiro diz respeito ao planejado, sendo da ordem do cálculo e o segundo nos fala do incalculável, do imprevisível, das surpresas, é diante deste último que trememos. Trememos diante do segredo inacessível de um Outro (na história de Abraão Deus) que decide por nós, ainda que tenhamos que decidir e sermos responsáveis sem compreendermos a lei ou as razões da lei na qual estamos inseridos e sobre a qual somos impelidos à responder.

Vimos que a resposta, as respostas, estão inseridas na estrutura do sacrifício, na medida em que respondemos e comemos, sacrificamos o outro, assimilamos, interiorizamos, nos apropriamos, nesse sentido, comemos o outro, este outro pode mesmo ser o que chamo de eu. Talvez, eu coma eu. Ou seja, talvez possamos pensar que a Débora come a Débora; Derrida come Derrida. Ao dizer, ao responder ao que me é herdado, às vezes por mim mesmo por exemplo, não estaria de certo modo, sacrificando parte de mim? Ou mesmo ao dizer que sou isso ou aquilo. Não estaria sacrificando parte, comendo parte? Poderíamos dizer, talvez, que herdamos algo que acreditamos ser eu, respondemos (comemos, nos apropriamos e desequilibramos) a este eu de maneira a deslocar o eu que antes acreditava ser eu, sendo agora um eu de eu. Onde não é mais possível saber os limites desse eu, sua unidade, sua essência, sua origem e formação. Não seria isso um certo alargamento? Certo deslocamento? Não é também isso que dizemos quando nos transformamos? Por que não dizer que fui sacrificada para ser isso ou aquilo? Por que pensar em parte de mim, como se mim fosse uma unidade natural? Talvez um mim de mim. Eu de eu. Talvez seja mesmo o eu que seja sacrificado; ao menos o que denominamos eu. Um eu que sacrifica eu. Um eu que come eu. Não seria, talvez, este um caminho a se pensar quando Derrida descreve o sujeito como rastro? A unidade de algo como nós mesmos, também estaria de algum modo desconstruída, deslocada, sacrificada. E assim, substituída, suplementada. Vimos que respondemos sacrificando visto que há pretensas apropriações, compreensões em que o outro acaba deixando de ser outro e passa a ser incluído, assimilado, comido. Esta relação do sacrifício com a responsabilidade e a responsividade aparecem também na história de Abraão.

\footnotetext{
${ }^{706}$ Derrida, A quién dar (saber no saber) In. Dar la muerte, 2006, p.65. Veja também início de Derrida (filme), Director: Kirby Dick, Amy Ziering Kofman, Estrelando Jacques Derrida, Marguerite Derrida, Zeitgeist films, (85 min), color, 2002.
} 
Deus exige de Abraão o sacrifício de seu filho Isaac. Tal exigência só se torna um sacrifício na medida em que ele deve matar algo de muito valioso, insubstituível. Se Abraão contasse aos amigos, a mulher, ou ao próprio filho, ele estaria na ordem da ética e do geral, como os heróis trágicos, nos diz Kierkegaard. Todos compreendem o herói e, nesse sentido, ele estaria inserido no geral. Mas como vimos, a responsabilidade para Derrida, e até certo ponto para Kierkegaard, é da ordem do absoluto, daquilo que não podemos compreender. E por isso, Abraão não pode contar, pois ninguém vai entender. Suas justificativas não serão suficientes para a ética geral. Assim ele mantém em segredo, se mantém só na própria singularidade e no momento da decisão e da responsabilidade. Estar na linguagem seria estar compreendido, respondendo diante do que se espera, do planejado, podemos pensar. Mas a linguagem ao mesmo tempo privaria e o livraria da sua singularidade, suspendendo sua decisão e sua responsabilidade já que todos decidem por ele o esperado e planejado. "Não há segredo último para o filosófico, o ético ou o político., ${ }^{, 707} \mathrm{Nem}$ para o sentido comum, para os discursos comuns ou dito científicos. Será que não haveria segredo do humano para o humano? De mim para mim mesmo? Podemos lembrar a frase do Raul Seixas, cantor brasileiro, em sua música Por quem os sinos dobram (1979) onde ele nos diz "convence as paredes do quarto e dorme tranquilo, sabendo no fundo do peito que não era nada daquilo."708 Não haveria sempre um segredo entre mim e mim mesmo, entre os discursos, entre os homens, um segredo entre? Um entre que é segredo? Compartilhar um segredo, neste caso, seria compartilhar não se sabe o que, nada que se possa determinar ${ }^{709}$, seria, talvez, compartilhar o injustificável? Aquilo que não se dá conta? Aquilo que não pode ser contado, compreendido, calculado, incluído. Mas que ao mesmo tempo desejamos, prometemos, convencemos até as paredes do quarto de vamos alcançar, satisfazer esta insaciedade.

Para o sentido comum, também para a razão filosófica, a evidência mais compartilhada é a que vincula a responsabilidade com a publicidade e com o não segredo, com a possibilidade, quer dizer, com a necessidade de dar conta, justificar ou assumir o gesto e a palavra diante dos outros. ${ }^{710}$

\footnotetext{
${ }^{707}$ Derrida, A quién dar (saber no saber) In. Dar la muerte, 2006, p.75

${ }^{708}$ Seixas, Raul, Por quem os sinos dobram. [faixa 5] Albúm Por quem os sinos dobram, 1979. A música pode não ter o sentido que estamos dando aqui.

${ }^{709}$ Derrida, A quién dar (saber no saber) In. Dar la muerte, 2006, p.92

${ }^{710}$ Derrida, A quién dar (saber no saber) In. Dar la muerte, 2006, p.72
} 
A responsabilidade e a decisão carregariam, por um lado, a intimação da resposta diante do geral, do estar na linguagem, em substituição. E por outro, carregariam a singularidade e a unicidade da não substituição, o silêncio e o segredo do não compartilhamento ${ }^{711}$. Elas carregariam este entre. E talvez por isso Derrida nos diga que "para que uma decisão seja justa e responsável, é preciso que, em seu momento próprio, se houver um, ela seja ao mesmo tempo regrada e sem regra, conservadora da lei e suficiente destruidora ou suspensiva da lei..." 712 Neste sentido, voltamos a apontar que a decisão não é da ordem do planejado, do cálculo, mesmo a decisão de calcular não o seria, mas toda decisão é assombrada pelo indecidível. Este permanece alojado como um fantasma em toda decisão, destruindo toda garantia de certeza ${ }^{713}$. "Indecidível é a experiência daquilo que, estranho, heterogêneo à ordem do calculável e da regra, deve entretanto - é de dever que é preciso falar - entregar-se à decisão impossível..."714

Em nome de um dever absoluto, de uma responsabilidade absoluta, de uma singularidade absoluta, traímos a ética, os nossos, somos tomados e tratados por eles como irresponsáveis. Responsabilidade absoluta como responsabilidade sacrificial. O que está em jogo em Kierkegaard será também desconstruído, quer dizer, alargado, deslocado ${ }^{715}$ em seus limites, pelo que Derrida acena como o chamado do Outro. O chamado de Deus a Abraão para sacrificar aquilo que lhe é insubstituível, que ama muito, mas que deve sacrificar em segredo, pois não pode ser compreendido, é tremido em suas margens por Derrida. Quando o autor nos questiona se este chamado não seria comum como chamado do outro, na relação com este outro cujas leis e razões não são justificáveis e que não poderiam ser. Estaria ele deslocando o discurso kierkegaardiano? Vamos desdobrar este deslocamento. Como justificar todas as ações, relações, decisões, escolhas, pensamentos...? Como justificar as últimas consequências este trabalho ter sido escrito em cima de autores tão importantes como Heidegger e Derrida em detrimento de muitos outros? Como justificar minha escolha em ser psicóloga e

\footnotetext{
${ }^{711}$ Derrida, A quién dar (saber no saber In. Dar la muerte, 2006, p.73

${ }^{712}$ Derrida, Força de lei: o fundamento místico da autoridade, 2007, p.44 Nesta obra, ele trabalha a noção de justiça como o impossível, incalculável e o direito como o que é calculado, planejado, previsível. Veja também Caputo, J. (ed.) Deconstruction in a nutshell. A conversation with Jacques Derrida, 1997, p.16-17. Não trabalharemos os detalhes desta distinção temos como objetivo apresentar a noção de decisão e responsabilidade para o autor.

${ }^{713}$ Derrida, Força de lei: o fundamento místico da autoridade, 2007, p.48

${ }^{714}$ Derrida, Força de lei: o fundamento místico da autoridade, 2007, p.46

715 Derrida, A quién dar (saber no saber) In. Dar la muerte, 2006, p.91
} 
estudar filosofia? Existiriam justificativas últimas? Justificativas justas? E a justiça é também da ordem do impossível ${ }^{716}$. Derrida mesmo aponta como justificar ter um gato em casa, no caso tenho quatro, em detrimento dos demais gatos do mundo? As respostas ao chamado do outro em última instância não tem fundo, nem limites, são injustificáveis, pois as justificativas e os critérios não possuem bases originárias, nem naturais, tampouco verdadeiras ou mais dignas. Com o injustificável entramos também na ordem do sacrifício. Não posso não responder ao outro sem sacrificar outro. Ao escolher Heidegger e Derrida, sacrifico Foucault, Sartre, Lacan, Freud... Ao escolher minha banca, sacrifico dezenas de outros professores doutores os que conheço e não conheço. Ao escolher meus gatos, por exemplo, também sacrifico todos os gatos do mundo. Eu repetidas vezes justifico assim para não levar mais gatos para casa: já levei (escolhi) quatro, não posso mais (devo sacrificar os demais). Não posso me responsabilizar diante de alguém, do outro, se não faltando com minhas responsabilidades, sendo irresponsável diante de todos os outros. "Jamais poderei justificar este sacrifício deverei sempre me calar a este respeito."717 Neste sentido Derrida nos descreve:

Desde o momento em que entro em relação com o outro absoluto, minha singularidade entra em relação com a sua no modo da obrigação e do dever. Sou responsável diante do outro em quanto que outro, o respondo e respondo diante dele. Mas, é claro, o que me vincula assim, em minha singularidade, com a singularidade absoluta do outro me joga imediatamente no espaço e no risco do sacrifício absoluto. ${ }^{718}$

Talvez tenhamos desdobrado mais a relação de responsabilidade absoluta e responsabilidade sacrificial. Responsividade pressupondo qualquer singularidade.

Dever absoluto diante do outro que sacrifico em detrimento de outro.

Dou a morte [...] Dia e noite, a cada instante, sobre todos os montes Moriah do mundo, estou fazendo isso, levantando a faca sobre aquele que amo e devo amar, sobre o outro, este ou aquele outro a quem devo fidelidade absoluta, incomensuravelmente. ${ }^{719}$

Não seria possível não trair e não sacrificar o outro. Abraão mesmo trai os seus em detrimento de Deus, ou trairia Deus em detrimento dos seus. Sacrifica de um lado e/ou de outro. Aporia e paradoxo como sacrifício. Não há generalidade

\footnotetext{
${ }^{716}$ Veja nota explicativa 711 desta pesquisa.

${ }^{717}$ Derrida, A quién dar (saber no saber) In. Dar la muerte, 2006, p.83

${ }^{718}$ Derrida, A quién dar (saber no saber) In. Dar la muerte, 2006, p.80

${ }^{719}$ Derrida, A quién dar (saber no saber) In. Dar la muerte, 2006, p.81
} 
ética sem o paradoxo do sacrifício, ela traduz a estrutura mesma do cotidiano. Onde qualquer radicalmente outro, nós ou todo e qualquer radicalmente outro é infinitamente outro em sua singularidade absoluta, inacessível, solitária, não presente. Voltamos à noção de rastro e diferança, de intervalo e entre, na medida em que não é possível apropriação, compreensão ou presentificação, uma vez que os limites, critérios, margens, certezas, não são óbvios e nem podem ser. Senão nada mais haveria para ser dito, escrito, falado, interpretado, pensado sobre ... o dito humano, por exemplo. No momento de resposta ou decisão diante de qualquer radicalmente outro, este nos pede que nos comportemos como cavaleiros da fé ${ }^{720}$, como aquele que está entregue ao dever absoluto, ao sacrifício que vem junto dele. Solitários, em segredo, sem poder justificar nossas escolhas, sacrificamos outros em detrimento de outro. A estrutura do sacrifício carrega a comilança, o comer bem, a apropriação, o desejo, uma vez que o humano viril aceita o sacrifício e come a carne ${ }^{721}$, sacrifica-se ao comer, ao apropriar aquele que é comido, dando-lhe a morte. Mas também sacrifica aqueles que não são, aqueles que não são escolhidos para serem comidos. Uma apropriação, um sacrifício jamais pode ser totalmente justificado, calculado. O sacrifício acenaria para a "necessidade, o desejo, a autorização, a justificativa de matar, a morte dada como denegação de assassinato." ${ }^{722}$ E agora, talvez, tenha ficado mais claro o segredo compartilhado do não se sabe o que, nada que se possa determinar ${ }^{723}$, que se possa justificar. Seria este também um segredo compartilhado entre psicólogos? Entre aqueles que estudam, interpretam e pensam, re-pensam, remarcam o dito humano?

Em seu texto Força de lei (1994) Derrida vai trabalhar em cima das noções de direito e de justiça, que não são nosso foco nesta pesquisa. No entanto, o autor aborda também o tema da responsabilidade de uma maneira que nos interessa aqui. Já tentamos descrever que o fato de Derrida não ser um autor do cálculo, da presença, do ser, da substância ou mesmo do sujeito, não significa de modo algum que ele esteja propondo um caos e que haja falta de rigor em suas leituras. O que está em jogo aqui é a resistência que se faz e se deve fazer diante de tais noções (cálculo, substância, sujeito ....) acenando para os limites e critérios em que elas se

\footnotetext{
${ }^{720}$ Derrida, A quién dar (saber no saber) In. Dar la muerte, 2006, p.91

${ }^{721}$ Derrida, Il faut bien manger ou le calcul du sujet In. Points de suspension. 1992, p. 295

${ }^{722}$ Derrida, Il faut bien manger ou le calcul du sujet In. Points de suspension. 1992, p.297

${ }^{723}$ Derrida, A quién dar (saber no saber) In. Dar la muerte, 2006, p.92
} 
apoiam. As pausas que existem, e o sujeito é também uma pausa, é aonde e por onde a desconstrução atravessa, balança e desestabiliza o que parecia pausa estável, o que parecia praça forte. Nesse sentido, ele nos diz que

ao desconstruir as repartições que instituem o sujeito humano (de preferência e paradigmáticamente o macho adulto, mais do que a criança ou o animal), como medida [critério] do justo e do injusto, não se conduz necessariamente à injustiça [ao caos, por exemplo] nem ao apagamento de uma oposição entre o justo e o injusto, mas talvez, em nome de uma exigência mais insaciável de justiça, à reinterpretação de todo o aparelho de limites nos quais uma história e uma cultura puderam confinar sua criteriologia. ${ }^{724}$

E se Derrida coloca em xeque os critérios e os limites de toda uma história que institui o sujeito humano como medida de justiça, nós também podemos pensar que ele coloca em xeque a instituição sujeito e humano e os próprios critérios e medidas que o instituem. Talvez seja também isso que ele desenvolva em seu texto Il faut bien manger ou le calcul du sujet. Uma vez que tais critérios não estão de forma alguma bem definidos e são tomados e tratados como óbvios não só em sentido comum no dia a dia, mas também pelas ciências que pensam o humano e, com isso, incluímos a própria psicologia e filosofia. Re-pensar tais critérios não seria dizer que não há tais humanos ou sujeitos, mas pensar a partir de onde ou a partir de que limites estes sujeitos e estes humanos são pensados e definidos. Em Heidegger como vimos, apesar de sua grande destruição do sujeito, tomado este como algo substancial possuidor de faculdades sensíveis e inteligíveis que apreenderiam objetos dados em um mundo, haveria, talvez, limites a se deslocar. Limites de um Dasein pensado a partir de sua relação privilegiada com o ser, determinado em um horizonte de ser, a partir de um destino do ser, "o advento do ente [todo ente, inclusive o homem] repousa no destino do ser." ${ }^{, 725}$ Destino da linguagem do ser, do espírito do ser, que é mais originariamente descrito, em alguns textos, a partir do sentido de Geist na língua alemã, ou grega ${ }^{726}$. E onde os destinos do ser teriam se essencializado como destinos epocais, épocas determinadas: grega, idade média, moderna, técnica. Quais seriam os limites destas épocas e destes horizontes? Se não há limites, como pensar todos os humanos como Dasein pertencentes ao destino do Ser? Ao

\footnotetext{
${ }^{724}$ Derrida, Força de lei: o fundamento místico da autoridade, 2007, p.36

${ }^{725}$ Heidegger, Sobre o humanismo 1973, p.356

726 "Pois a língua grega, medida pelas possibilidades do pensamento, é, ao lado da alemã, a mais poderosa e a mais cheia de espírito.” (Heidegger, Introdução à metafísica, 1999, p.85)
} 
mais originário referindo-se a um Geist - originariamente descrito e "acessado" pelo povo alemão? A uma Geschlecht, talvez, ainda delimitada? Se Heidegger nos abriu diante da compreensão moderna do homem, do mundo e das coisas, esta abertura tinha ainda a pretensão de uma propriedade, de uma verdade, de uma origem, muitas vezes assentada sobre um idioma e um Geschlecht específicos. Estamos nós fadados ao destino desta origem? Do espírito do ser? Espírito Alemão? Grego? Latim? Quem seriam estes que teriam acesso a esta verdade propriedade - origem?

Poderíamos talvez sugerir e acenar para certa diferença no que diz respeito aos horizontes. Em Heidegger um horizonte epocal pode ser nomeado, como vimos pelos modos de destinação do ser, onde o Dasein humano acaba sendo determinado a partir deste horizonte, a partir da linguagem do ser. Para Derrida, a ideia de horizonte é complicada, e nesse sentido confessa manter determinada reserva. Uma vez que a noção de horizonte, "como seu nome indica em grego, é ao mesmo tempo a abertura e o limite da abertura, que define ou um progresso infinito, ou uma espera." 727 Em $O$ monolinguismo do outro ou a prótese de origem (1996), Derrida nos confessa que, a estrutura de promessa ou do desejo na qual estaríamos jogados acenaria para uma espera sem horizonte de espera, de esperança $^{728}$. Já estou jogado numa espera sem saber o que vai me acontecer, o que me espera. Não haveria como se apropriar de suas margens, determiná-lo nem abordar seus limites e arestas. Nem mesmo um destino estaria descrito em um horizonte. Uma promessa não sabe se será cumprida. Não há como sair da linguagem, de um horizonte para falar dele, uma vez que os limites não são óbvios, nem naturais, nem ontológicos. Impossível metalinguagem absoluta. Lembremos, quando ele nos diz que não há fora texto. Haveria apenas a miragem de outra língua, de outro horizonte ${ }^{729}$. O que haveria nesta estrutura é uma espera sem horizonte, um desejo sem horizonte. Uma "espera sem horizonte de uma língua que apenas sabe fazer-se esperar." ${ }^{, 730}$ Nesse sentido um horizonte não chega a ser determinado. Pois se encontraria em espera, fazendo-se esperar. Isto é um tanto paradoxal, pois esperamos algo que não pode vir, sua vinda seria a

\footnotetext{
${ }^{727}$ Derrida, Força de lei: o fundamento místico da autoridade, 2007, p.51

${ }^{728}$ Derrida, O monolinguismo do outro ou a prótese de origem, 2001, p. 35

${ }^{729}$ Derrida, $\mathbf{O}$ monolinguismo do outro ou a prótese de origem, 2001, p. 36

${ }^{730}$ Derrida, O monolinguismo do outro ou a prótese de origem, 2001, p. 104
} 
totalidade, seria a morte ${ }^{731}$. A experiência aconteceria sempre em um horizonte de espera, de promessa.

Sem dúvida, vimos que Derrida acompanha em muito o pensamento de Heidegger, mas também se distancia, nos mostrando alguns limites e margens de tal discurso, re-pensando, re-marcando e com isso, alargando-o e transbordando-o. Novamente a passagem: "é desde uma certa desconstrução, em todo caso aquela que me interessa, que nós podemos colocar, me parece, novas questões à Heidegger, decifrar seu discurso, situar os riscos políticos e reconhecer por vezes os limites de sua própria desconstrução."732 Poderíamos falar mais de tais limites, limites que mesmo Derrida muitas vezes sabe estar "inserido", e que, porventura também será transbordado em textos que estão porvir. Entregue à superação, à substituição, à tradução. Novamente a passagem já citada, a "diferança pode muito bem, deverá um dia ser superada, prestar-se por si mesma, se não a sua própria substituição, pelo menos ao seu encadeamento numa cadeia que na verdade, ela não terá jamais governado." ${ }^{, 733}$ Em uma entrevista de Antoine Spire en Staccato, programa televisivo de France Culturel, de 6 de julho de 1999, Derrida nos conta "sempre estou disposto, quando posso fazê-lo, a reconsiderar umas injustiças devidas ao distanciamento, à simplificação. [...] sempre estou disposta a ler, a reler, a reconsiderar." ${ }^{734}$ Derrida acena sua disposição à reconsiderar discursos, clausuras, não em detrimento de uma salvação, de uma verdade, de uma originariedade, mas como movimento mesmo do entre, do rastro, nem verdade, nem falsidade, assim ele nos diz:

eu assino de imediato sinceramente aquilo que você talvez acabou de ler. Não como o sintoma de uma "verdade", a minha, mais como uma oração, aquela em que Aristóteles dizia tão precisamente que ela não é "nem verdadeira nem falsa. ${ }^{735}$

A desconstrução é assim pensada a partir de dois movimentos neste texto Força de lei: o fundamento místico da autoridade. Por um lado Derrida pensa esta responsabilidade excessiva, onde o cálculo ou as medidas não poderiam de

\footnotetext{
${ }^{731}$ Caputo, J. (ed.) Deconstruction in a nutshell. A conversatiom with Jacques Derrida, 1997, p. 25

${ }_{732}$ Derrida, Heidegger l'enfer des philosophes, In. Point de suspension, 1987, p.199

${ }^{733}$ Derrida, A Diferença In. Margens da filosofia, 1991, p.38

${ }^{734}$ Derrida, Sobre a fenomenologia, de Antoine Spire en Staccato, programa televisivo de France Culturel, de 6 de julho de 1999. (Grifado nosso)

${ }^{735}$ Derrida, Le survivant, le sursis, le sursaut, In. Penser à ne pas voir, 2014. p.369
} 
forma alguma reger suas ações. E sim a lembrança como tarefa rigorosa de pensar e re-pensar os pressupostos que estão em jogo nas normas, nos valores, nas prescrições e em outros conceitos trabalhados neste texto como os de direito, justiça e lei. Tal tarefa diz respeito à responsabilidade diante de uma herança, da maquinária conceitual, herdamos muitos conceitos, comportamentos, hábitos, manias, enfermidades talvez. E devemos de algum modo escutar estas heranças, seus pressupostos, seus limites, suas falas, muitas vezes singulares. Herança esta sem pressuposição de apropriação, alcance, uma vez que é uma herança desde sempre esclerosada ${ }^{736}$.

Por outro lado, um segundo movimento acenado seria responsabilizar-se diante do próprio conceito de responsabilidade que carregaria consigo a ideia de um sujeito autônomo, dotado de vontade, liberdade, consciência, decisão ... desconstruir esta rede de conceitos imbricados na noção de sujeito que também é um termo a se desconstruir. Tal momento de desconstrução que levaria a uma suspensão, epokhé angustiante, o autor nos descreve, "só poderia ser motivado, só pode encontrar seu movimento e seu elã (um elã que, por sua vez, não pode ser suspenso) na exigência de um aumento ou de um suplemento de justiça." ${ }^{\text {737 }} \mathrm{A}$ desconstrução encontra seu movimento nesse apelo insatisfeito, na exigência deste aumento, do suplemento, do que pode vir, porvir. No desejo e na promessa de presença, de totalidade, de fim, de eu, de ego, de unidade, de ...

Finalizamos este sub capítulo com a passagem a seguir, retirada de uma das perguntas e respostas realizadas em um debate na Universidade de Villanova, Pensilvânia, onde Derrida foi questionado acerca do lugar da unidade na desconstrução, uma vez que esta desconstruiria totalidades e unidades se perdendo, talvez, na diversidade. A passagem nos esclarece também acerca do que está em jogo para a questão da identidade, bem como da responsabilidade e decisão no pensamento de Derrida.

Não acho que tenhamos que escolher entre unidade e multiplicidade. [...] A desconstrução [...] tem insistido não na multiplicidade por si mesma, mas na heterogeneidade, na diferença, na dissociação, que é absolutamente necessária para a relação com o outro. Aquilo que rompe a totalidade é a condição para a relação com o outro. O privilégio garantido à unidade, à totalidade, aos conjuntos orgânicos, à comunidade enquanto um todo homogêneo, - isto é um perigo para a responsabilidade, para a decisão, para a ética, para a política. Esta é a razão pela qual eu insisto sobre aquilo que impede que a unidade se feche, que seja

\footnotetext{
${ }^{736}$ Derrida, O monolinguismo do outro ou a prótese de origem, 2001, p.72

${ }^{737}$ Derrida, Força de lei: o fundamento místico da autoridade, 2007, p.39
} 
fechada. Isto não é só uma questão de descrever as coisas, de dizer que algo é porque é. É uma questão de contar com a possibilidade de responsabilidade, de decisão, de compromisso ético. Para entender isso, tem que prestar atenção no que eu chamo de singularidade. Singularidade não é simplesmente unidade ou multiplicidade. Agora, isto não significa que temos que destruir todas as formas de unidade quando ocorrerem. Eu nunca disse nada disso. Evidentemente, nós precisamos de unidade, de alguma forma de reunião, de alguma configuração. Pura união ou pura multiplicidade [...] seria sinônimo de morte. O que me interessa é o limite de toda tentativa de totalizar, de reunir, [...], o limite desta unificação, deste movimento unificador, o limite que este movimento tem que encontrar, porque a relação da unidade consigo mesma implica alguma diferença. Para ser mais concreto, tomemos o exemplo de uma pessoa ou de uma cultura [...] a identidade de uma cultura é um modo de ser diferente dela mesma; uma cultura é diferente dela mesma; a linguagem é diferente dela mesma, uma pessoa é diferente dela mesma. Quando se leva em conta esta diferença [...], então se percebe o outro, e se compreende que a luta pela própria identidade não é exclusiva em relação a uma outra identidade, ela é aberta a uma outra identidade. Isto é o que previne o totalitarismo, o nacionalismo, o egocentrismo etc. [...] a identidade é uma identidade que se auto-diferencia de si mesma, uma identidade diferente dela mesma, que contém uma abertura ou lacuna nela mesma. Isto afeta por completo uma estrutura [da identidade], mas é um dever, um dever ético e político, levar em conta esta impossibilidade de ser um consigo mesmo. É porque eu não sou um comigo mesmo que eu posso falar com o outro e endereçar-me ao outro. Isto não é um modo de evitar a responsabilidade. Ao contrário, é o único modo para mim de assumir a responsabilidade e tomar decisões. [...] Quando se dá privilégio para a reunião e não para a dissociação aí não se deixa espaço para o outro, para a radical outreidade, para a radical singularidade do outro. ${ }^{378}$

\section{3 \\ O "humano" a partir do monolinguismo do outro}

Vamos desenvolver esta parte da pesquisa com base no texto Le Monolinguisme de l'autre, ou, La prothèse d'origine (1996) onde Derrida vai abordar um pouco de sua biografia a partir do quase mantra ou demonstração, gesto, hipótese da seguinte sentença, que será pronunciada de diferentes formas e que irá acenar para o chamado do outro, a herança e a hospitalidade, o sujeito e linguagem: "eu não tenho senão uma língua e ela não é minha."739 "não falamos [no plural] nunca senão uma única língua, não falamos nunca uma única língua."740 Digo certa biografia, pois Derrida além de nos contar um pouco sua história ele trata e fala em primeira pessoa, de um eu, chamado Derrida, mas que acenaria para todos os eus, um eu precedido pelo monolinguismo, do qual não

\footnotetext{
${ }^{738}$ Caputo, J. (ed.) Deconstruction in a nutshell. A conversation with Jacques Derrida,1997, pp.13-14 (Grifado nosso)

${ }^{739}$ Derrida, O monolinguismo do outro ou a prótese de origem, 2001, p. 13

${ }^{740}$ Derrida, O monolinguismo do outro ou a prótese de origem, 2001, p. 19
} 
podemos ultrapassar. "Ele [monolinguismo] constitui-me, dita-me mesmo a ipseidade de tudo." ${ }^{741} \mathrm{E}$ um pouco adiante no texto ele continua: "a nossa questão é sempre a identidade." ${ }^{, 72}$ Ou melhor, a não identidade a si.

A ipseidade vai apontar para o que ele chama de hospitalidade, como já falamos anteriormente, o quem do sujeito pressuporia a estrutura da hospitalidade. Uma vez que estaríamos sempre sendo hospedados, convidados a habitar, nos familiarizar com os costumes, hábitos de outro, as possibilidades de um eu estariam precedidas por outro que hospeda em sua casa. Uma casa que nunca será minha. Mas que também nunca foi de quem hospeda. Hábitos que não são meus, mas daquele que me hospeda, mas também não são totalmente dele. Mas do hospedeiro do hospedeiro do..., estrutura de hospitalidade. Haveria certa hostilidade nesse lugar que se hospeda, na medida em que não é meu, não são meus hábitos, nem meu habitat. De quem seriam então os hábitos, a hospedagem? Um hóspede estaria sempre refém da onde se hospeda, pois não possui naturalmente, ontologicamente, culturalmente, socialmente, hábitos que sejam dele. Ele já é hospedado nessa estrutura hospitaleira. Já responde ao outro que o hospeda. A hospitalidade dá a palavra ao estrangeiro ${ }^{743}$. "Desde então, qualquer pessoa deverá poder declarar sob juramento: eu não tenho senão uma língua e ela não é minha, a minha "própria" língua é-me uma língua inacessível. A minha língua, a única que me ouço falar e me ouço a falar, é a língua do outro."744 A passagem a seguir é bem descrita por Derrida acenando para a cadeia semântica que trabalha a hospitalidade e a hostilidade reconstituída por Benveniste:

[a ipseidade] significa talvez, em primeiro lugar, o poder de um 'eu posso', mais originário do que o 'eu', numa cadeia em que o 'pse' de ipse não se deixa mais dissociar do poder, do domínio ou da soberania do hospes (refiro-me aqui à cadeia semântica que trabalha no corpo a hospitalidade tanto quanto a hostilidade - hostis, hospes, hosti-pet, posis, despotes, potere, potis sum, possum, pote est, potest, pot sedere, possidere, compos, etc). ${ }^{745}$

Não é um eu que pode, mas um pse lançado na estrutura do poder e da soberania de um hospes, de um hospedeiro. A ipseidade estaria talvez neste jogo de hospedagem, acolhimento, engajamento, afirmação, sim, sim sim, que me viola, enquanto estrangeiro, enquanto quem, enquanto dito sujeito, me usurpa, me

\footnotetext{
${ }^{741}$ Derrida, O monolinguismo do outro ou a prótese de origem, 2001, p. 14

${ }^{742}$ Derrida, O monolinguismo do outro ou a prótese de origem, 2001, p. 27

${ }^{743}$ Derrida, Força de lei: o fundamento místico da autoridade, 2007, p.6

${ }^{744}$ Derrida, O monolinguismo do outro ou a prótese de origem, 2001, p.39

${ }^{745}$ Derrida, O monolinguismo do outro ou a prótese de origem, 2001, p. 27
} 
violenta, me impõe o que não é meu e me mostra que o que eu acreditava ser meu tampouco o é. É meu e não é meu. Estrutura antinômica na qual estaríamos em jogo. "Não há $X$, não há senão X.",746 "Eu não tenho senão uma língua e ela não é minha." ${ }^{, 77}$ A total impossibilidade de alcançar, apropriar, compreender e o desejo e a promessa de algo como necessárias. Impossível necessário. Uma vez que não se apropria, ou só se "apropria" em pequenas pausas. Existe nessa antinomia, como ele mesmo a chama, que será repetida diversas vezes, a estranha relação entre o impossível (interdito) e o necessário, que vai abrir a tradução, a transformação, e o que entendemos por suplemento, substituição que não cessa de acontecer e se dar. É o que torna possível a estrutura de expropriação. E nesse sentido, a noção de maestria, senhoria, verdade, presença, propriedade, substância, essência, língua materna acabam por ser deslocadas, alargadas, inscritas nessa estrutura monolingue, hospitaleira e hostil. Talvez seja isso que Derrida esteja descrevendo nas passagens a seguir.

Porque, contrariamente ao que somos a maior parte das vezes tentados a crer, o senhor não é nada. E não tem nada de próprio. Porque não possui como próprio, naturalmente, o que no entanto chama a sua língua; porque independente do que queira ou faça, não pode entretecer com ela relações de propriedade ou de identidade naturais, nacionais, congenitais, ontológicas; porque não pode não acreditar e dizer esta apropriação senão no decurso de um processo não natural de construções político-fantasmáticas; porque a língua não é o seu bem natural, ele pode justamente por isso historicamente, através da violação de uma usurpação cultural, ou seja, sempre de essência colonial, fingir, apropriá-la para a impor como "a sua". 748

Este discurso da ex-propriação da língua, mais precisamente da "marca", abre para uma política, para um direito e para uma ética; [...] e justamente porque o equívoco indecidível corre tais riscos e apela portanto à decisão [à responsabilidade], aí onde, antes de qualquer programa e mesmo antes de qualquer axiomática, ela condiciona o direito e os limites de um direito de propriedade, de um direito à hospitalidade, de um direito à ipseidade em geral, ao "poder" do próprio hospes, dono e senhor, e em particular de si mesmo - ipse, compos, ipsissimus, despotes, potior, possidere. ${ }^{749}$

Nesta estrutura de ipseidade uma alienação ${ }^{750}$ constitutiva estaria em jogo, não como uma falta que aliene uma ipseidade, uma propriedade, uma relação a si. Não há um si que se encontre consigo mesmo, um mesmo que se mantém como

\footnotetext{
${ }^{746}$ Derrida, O monolinguismo do outro ou a prótese de origem, 2001, p. 33

${ }^{747}$ Derrida, O monolinguismo do outro ou a prótese de origem, 2001, p. 13

${ }^{748}$ Derrida, O monolinguismo do outro ou a prótese de origem, 2001, p.37-38

${ }^{749}$ Derrida, O monolinguismo do outro ou a prótese de origem, 2001, p.38-39

${ }^{750}$ Derrida, O monolinguismo do outro ou a prótese de origem, 2001, p.39

${ }^{750}$ Derrida, O monolinguismo do outro ou a prótese de origem, 2001, p. 39
} 
mesmo, que possa ter estado presente, representado velando a si mesmo. Alienação inalienável, interdição a partir da qual digo e me digo ${ }^{751}$, fala deste jogo impossível - necessário, interdito - prometido (desejado). Um jogo espectral, fantasmático [lembremos do Geist do Geist], de substituições, suplementos, dobras, próteses, do rastro do rastro. Existe assim um destino que nos colocaria numa estrutura de promessa, de desejo de uma única língua, mas interditando-nos a sua apropriação. Destino que não alcança seu fim, destino errante, destinerrante. Há doação de língua, mas uma língua não é dada, não existe e não é. “Apelada ela apela, como a hospitalidade do hóspede antes mesmo de qualquer convite."752

O monolinguismo do outro tem certamente o rosto e os traços ameaçantes da hegemonia colonial. Mas o que nele permanece inultrapassável, qualquer que seja a necessidade ou a legitimidade de todas as emancipações, é muito simplesmente o "há a língua", um "há a língua que não existe", a saber que não há metalinguagem e que sempre uma língua será chamada a falar da língua porque esta não existe. ${ }^{73}$

Qualquer noção de eu, ego, pessoa, identidade, sujeito, humano já estaria precedido por esta estrutura que estamos tentando descrever. Situado numa experiência insituável da língua, numa situação inencontrável, reenviando, endereçando, destinando-se sempre a algures. Desejando e prometendo a si mesmo, desejo ao mesmo tempo do puro, da origem e do fim, da propriedade e da verdade, uma hiperbolite incurável ${ }^{754}$. Tal hiperbolite acontece nessa estrutura de promessa, de tradução, substituição, suplemento. Neste entre em que "eu não tenho senão uma língua e ela não é minha."755 Onde se por um lado nada é intraduzível, uma vez que traduzimos as falas, as palavras, os discursos, por outro tudo é intraduzível. Sendo a tradução outro nome do impossível. "Num outro sentido da palavra 'tradução', claro, e de um sentido ao outro é-me fácil manterme sempre firme entre estas duas hipérboles que no fundo são a mesma e se traduzem ainda uma na outra." ${ }^{, 756}$ E por isso a própria experiência, habitação só é possível a partir da diferença entre o exílio e a nostalgia ${ }^{757}$, entre a perda (alienação inalienável) e o desejo nostálgico, entre o apagamento e o transbordamento, entre...

\footnotetext{
${ }^{751}$ Derrida, O monolinguismo do outro ou a prótese de origem, 2001, p.47

${ }^{752}$ Derrida, O monolinguismo do outro ou a prótese de origem, 2001, p. 99

${ }^{753}$ Derrida, O monolinguismo do outro ou a prótese de origem, 2001, p. 102 (Grifado nosso)

${ }^{754}$ Derrida, O monolinguismo do outro ou a prótese de origem, 2001, p.66

${ }^{755}$ Derrida, O monolinguismo do outro ou a prótese de origem, 2001, p. 13

${ }^{756}$ Derrida, O monolinguismo do outro ou a prótese de origem, 2001, p. 88 (Grifado nosso)

${ }^{757}$ Derrida, O monolinguismo do outro ou a prótese de origem, 2001, p. 90
} 
A monolíngua fala de uma identidade, mas como não identidade a $\mathrm{si}^{758} \mathrm{de}$ toda a língua, traduzindo uma língua que não foi presente, não foi uma consigo mesma $^{759}$. Mas que retorna para falar. Novamente a passagem: “uma língua será chamada a falar da língua.” ${ }^{, 760}$ E não será isso que estávamos tentando pensar no sujeito como rastro? Por não haver o sujeito, fala-se sobre sujeito. Por não haver o humano, fala-se sobre humano. Mas este nunca é uma coincidência a si, uma unidade, essência que pode ser alcançada, apreendida, mas deslocada, alargada, re-pensada.

O monolinguismo do outro é assim soberano, lei que vem de algures, mas vem, lei como língua, da qual não posso não falar, mas que permanece heterônoma ${ }^{761}$. Tendência a unidade, reduzindo às línguas e impondo soberanamente a pretensa hegemonia do homogêneo. Não se reduz a uma identidade $^{762}$. O monolinguismo do outro acena para o desejo de identidade, alisando os textos por onde coloniza e hospeda. Ela, esta monolíngua, é do outro e ao outro se reconduz. O de - do outro - não é uma propriedade nem uma proveniência: "a língua é do outro, vem do outro, (é) $a$ vinda do outro., ${ }^{, 763}$ Por isso Derrida nos descreve que,

todas estas palavras: verdade, alienação, apropriação, habitação, casa (própria), ipseidade, lugar do sujeito, lei, etc, permanecem problemáticas aos meus olhos. Sem excepção. Todas elas transportam o selo desta metafísica que justamente, se impôs através desta língua do outro, deste monolinguismo do outro. ${ }^{764}$

Esta monolíngua é afásica, está privada de toda e qualquer língua, lançada na tradução absoluta, na suplementariedade, na prótese sem origem, sem pólo de referência, sem língua originária. Só existiriam línguas de chegada, mas que nunca chegam a chegar, não sabem da onde vem e tampouco reconhecem seu trajeto. Acontecimentos sem chegada. A partir destas chegadas, o desejo existe, antes de um eu-mim, de uma ipseidade. Transportado pela própria chegada o eumim "surge, erige-se mesmo como desejo de reconstituir, de restaurar, mas na verdade de inventar uma primeira língua que seria antes uma ante-primeira língua

\footnotetext{
${ }_{758}$ Derrida, O monolinguismo do outro ou a prótese de origem, 2001, p. 97

${ }^{759}$ Derrida, O monolinguismo do outro ou a prótese de origem, 2001, p. 90

${ }^{760}$ Derrida, O monolinguismo do outro ou a prótese de origem, 2001, p. 102

${ }^{761}$ Derrida, O monolinguismo do outro ou a prótese de origem, 2001, p.56

${ }^{762}$ Derrida, O monolinguismo do outro ou a prótese de origem, 2001, p.45

${ }^{763}$ Derrida, O monolinguismo do outro ou a prótese de origem, 2001, p. 101

${ }^{764}$ Derrida, O monolinguismo do outro ou a prótese de origem, 2001, p. 91
} 
destinada a traduzir esta memória." ${ }^{765}$ Uma memória que como vimos é esclerosada. Esta memória do que foi herdado, pretensamente originado em algum lugar. Desejo de reconstituição, promessa anunciando a unicidade de uma língua por $\operatorname{vir}^{766}$. Traduzir a memória do que não teria tido lugar "do que, tendo sido (o) interdito, deve ao menos, ter deixado um rastro, um espectro, o corpo fantasmático, o membro-fantasma - sensível, doloroso, mas à justa legível -, rastros, marcas cicatrizes. ${ }^{, 767} \mathrm{Um}$ eu-mim como espectro, rastro, fantasma que carrego, desejo, prometo, que como (talvez), mas que nunca é apropriado, saciado, cumprido enquanto promessa. Um eu-mim que traduz eu-mim que traduz-eu-mim. Fazendo história em negativos (de fotografias) do que não aconteceu, "tal ante-primeira língua não-existe." 768 Ela "acontece" correndo o risco de querer ser ainda e novamente a língua do [novo] mestre. Por não existir é preciso inventá-la ${ }^{769}$. Sujeito como fábula. A história de um eu que acontece sem chegar, pois nunca aconteceu, de um eu que se destina rastreando os espectros de sua memória que deseja reconstituir.

Há sempre reapropriação, Derrida confessa sonhar em escrever uma anamnese do que o permitiu identificar-se ou dizer "eu" a partir de um fundo de amnésia e de afasia. Esta escrita, ele continua, só poderia ser realizada abrindo vias impossíveis, inventando para não se deixar reapropriar pelas normas, pela lei da língua dada ${ }^{770}$. O inaugural é impossível, promete-se o impossível, mas há sempre reapropriação. Reapropriações que não são como identidades, nem unidades, mas pausas, unicidades ou singularidades "de uma reunião da sua diferença a si: na diferença consigo mais do que na diferença de si consigo."771 Novamente esta passagem nos esclarecerá: uma singularidade que se "desloca ou se divide ao reunir para responder ao outro, cujo chamado precede de alguma forma sua própria identificação a si, pois a este chamado eu não posso não responder, ter já respondido, mesmo acreditando que estou respondendo não."772 Pequenas pausas e reuniões para responder ao outro. Seria o dito humano marcado, re-marcado por pequenas pausas e reuniões? Que dividem e deslocam,

\footnotetext{
${ }^{765}$ Derrida, O monolinguismo do outro ou a prótese de origem, 2001, p. 93

${ }^{766}$ Derrida, $\mathbf{O}$ monolinguismo do outro ou a prótese de origem, 2001, p. 100

${ }^{767}$ Derrida, $\mathbf{O}$ monolinguismo do outro ou a prótese de origem, 2001, p. 93

${ }^{768}$ Derrida, O monolinguismo do outro ou a prótese de origem, 2001, p. 94

${ }^{769}$ Derrida, O monolinguismo do outro ou a prótese de origem, 2001, p. 96

${ }^{770}$ Derrida, O monolinguismo do outro ou a prótese de origem, 2001, p. 98-99

${ }^{771}$ Derrida, O monolinguismo do outro ou a prótese de origem, 2001, p. 100

${ }^{772}$ Derrida, Il faut bien manger ou le calcul du sujet In. Points de suspension. 1992, p.276
} 
desequilibram o dito humano hiper deslocado, desejando mais, sofrendo de hiperbolite aguda, para responder ao outro.

Não seria, talvez, o sofrimento e a dor de um dito humano também uma pequena pausa? Seria talvez, possível alargá-la, desequilibrá-la, deslocar neste processo desconstrutivo, tremendo limites e margens que sustentavam esta pausa? Seria este, um possível trabalho, re-trabalho do psicólogo? A partir do momento em que ele no gesto, traduz, ajudando a deslocar, tremendo bordas que pareciam nunca emergir. Poderia enviar esta re-marca, uma vez que esta pesquisa é também uma re-marca, um re-pensar, aos que estão porvir? Psicólogos, mas não só eles.

\section{4}

\section{Humano como rastro}

Nesta última parte deste capítulo vamos continuar a deslocar o dito humano a partir da leitura derridiana, tentando nos aproximar de uma possível relação de responsabilidade com e sobre ele. Neste sentido, a partir de uma entrevista realizada em 2004 para a Revista La Quinzaine littéraire (Paris), em que Derrida é chamado junto a outros autores a responder a pergunta "Pour qui vous prenezvous?" [Por quem você se toma?], que poderia ser recolocada de diferentes formas: por quem você se compreende/apreende? Por quem você se compreende como você? Por quem você se compreende como quem? Quem é você? Quem é quem? Quem pergunta pelo quem? Quem compreende/apreende/toma quem? Todas estas perguntas, talvez, acenem também para o dito humano.

Derrida ainda acrescenta a seguinte questão será que a pergunta não traria um "se tomar por algo que a gente na verdade não é?"773 se tomar por outro? Me tomar como outro? Um Derrida que se toma como Derrida'? Ou um X que se toma como X'? Onde X não seria de modo algum algo indivisível, uno, fechado, enclausurado, onde suas bordas transbordam de modo a não saber mais o que o abordava inicialmente. O que talvez anunciaria uma substituição? Um fantasma ele nos diz. Esta questão que chama Derrida a responder começa a nos ajudar a deslocar a noção de sujeito, humano, eu. A noção daquilo, disso, que talvez, nos tomemos por nós mesmos? Nós? Quem?

\footnotetext{
${ }^{773}$ Derrida, Le survivant, le sursis, le sursaut, In. Penser à ne pas voir, 2014, p.364
} 
Numa primeira confissão, ele nos conta:

eu tenho muito a tendência a me tomar somente por quem a gente/os outros [on] me toma[m], a me tomar aqui onde eu sou tomado, como eu sou tomado [pris], surpreendido [surpris], compreendido [apreendido] [compris] pelos outros, e então a mudar aos meus olhos minha própria imagem à critério do que os outros [on] me reenviam: nas minhas famílias, onde eu já tenho mais de um rosto [visage], segundo os amigos e as amigas, de um indivíduo a outro, do bebê à velhice, nos meios profissionais e nas diversas instituições as quais eu pertenço ... ${ }^{774}$

Derrida confessa primeiramente a tendência a se tomar como a gente/os outros o toma[m], desde bebê à velhice e, antes mesmo, poderíamos dizer. Antes mesmo de nascer uma herança já era herdada, reenviada, endereçada aos outros cujo modo de tomar Derrida é, como, ele afirma, tendencialmente do outro. Antes dele nascer por exemplo, algo como bebê, fralda, seio, judaísmo, África, Algéria, França, mãe, pai, irmão, amigos, terra, água, leite, fome, humano, sujeito..., já eram tomados (pris), herdados pelos outros à outros, de outros. Desde modo, fica mais claro quando ele nos diz que "eu sou tomado antes de me tomar." Tomado por outro, dos outros, por outros de outros.

É interessante também acenar para o pronome pessoal on [traduzido aqui por os outros, mas mantemos o 'a gente' como marca] onde Derrida parece se tomar como a gente o toma, como a gente o reenvia, conforme as passagens "por quem a gente [on] me toma"; "à critério do que a gente [on] me reenvia". Neste [on] a gente, os outros, pronome indefinido, são todos, mas ninguém definido, os outros, onde Derrida parece também se incluir, ele também é os outros, de certo modo, de maneira a se tomar como os outros [on - os outros/a gente e ele como outro] o tomam, o reenviam a partir de uma herança já tomada, reenviada pelos outros, para os outros. Podemos lembrar aquele conto do Sartre intitulado L'enfance d'un chef (1939) onde, logo no ínicio, o pequeno Lucien é chamado de mocinha pelo Sr. Bouffardier e fica já não muito seguro de não ser uma menina, tendo até mesmo receio de que as pessoas decidissem de repente que ele não era mais um menino. A ontologia Sartriana, o Para outro assentado num olhar humano e a psicanálise existencial sartriana o distanciam do que estamos tentando trazer aqui sobre Derrida, não sendo tampouco foco da nossa pesquisa. O conto é trazido como elemento para re-pensarmos e elucidarmos algo que o autor francomagrebino tenta confessar. Ou podemos lembrar também o Das man (impessoal) de Heidegger, onde o quem é determinado por todos e ninguém, onde falamos

\footnotetext{
${ }^{774}$ Derrida, Le survivant, le sursis, le sursaut, In. Penser à ne pas voir, 2014, p.365
} 
como se fala, fazemos como se faz. A estrutura existencial do Das man de Heidegger estaria relacionada a uma ontologia fundamental como pudemos descrever no início de nossa pesquisa e pudemos a partir de Derrida acenar para certo deslocamento, re-pensando os limites de uma ontologia, das relações propriedade-impropriedade, verdade e não verdade em jogo na essência deste Das man.

Em relação a este ser tomado pelos outros, como os outros o tomam, Derrida continua sua confissão ao dizer que tentava resistir aos reenvios dele reenviados pelo outro. Resistência desde jovem encontrando os rastros em tudo aquilo que fazia, dizia, ou escrevia. Em sua resistência, ele se questionava, "quem é este "eu" que é ou permanece [reste] um outro, além daquele que se acha assim "tomado", cativo (não cativado, mas capturado), definido, determinado por uns e outros?",775 Quem seria este "eu", o dito eu, o dito humano, sujeito, talvez, que é além do eu que é tomado, determinado pelos outros? Poderíamos ainda chamar de eu? Responder e perguntar a partir de um quem? Acreditar que é? "Ninguém átras da persona" 776 , onde persona aponta para a noção de máscara, personagem, outro de mim. Máscaras atrás de máscaras, ninguém atrás da máscara, nenhuma essência, nenhuma verdade atrás da máscara, poderia dizer Derrida. O autor continua a confissão nos dizendo que nunca matou esta questão nele. Que só conseguiu respondê-la pelas estratégias de compromisso: surpreendendo, sobressaltando (sursaut, faire sursaut), as surpresas nos sobressaltam, onde os outros $[o n]$ me tomam, mas também respondendo, correspondendo [responsavelmente], corrigindo aquilo que os outros [on] acreditam que eu sou e devo ser, conforme a imagem [máscara, papel, personagem] que os outros [on] acreditam ter de $\operatorname{mim}^{777}$. Talvez respondendo à questão, ele teria matado a questão. Nada mais haveria a dizer, pensar, re-pensar. Não respondendo, não matando, e assim ele resistia, encontrando os rastros em tudo aquilo que ele dizia, fazia, escrevia.

Resistindo assim, sacrificaria ele o sacrifício? Talvez. Em alguns momentos, talvez. Seguindo os rastros, resistia. Não se comia, não se sacrificava, não se apreendia como o apreendem, não se tomava como o tomam. Caso contrário,

\footnotetext{
${ }^{775}$ Derrida, Le survivant, le sursis, le sursaut, In. Penser à ne pas voir, 2014, p.366

${ }^{776}$ Derrida, Le survivant, le sursis, le sursaut, In. Penser à ne pas voir, 2014, p.366

${ }^{777}$ Derrida, Le survivant, le sursis, le sursaut, In. Penser à ne pas voir, 2014, p.366
} 
pronto! Agora ele talvez fosse uma menininha como Lucien acreditava no conto sartriano. Ele era e não era. Assim resistia, seguindo os rastros das heranças que eram reenviadas aos outros pelos outros. Esta resistência, nos diz Derrida, "à uma imagem que me reenvia aqui graças a tal outro que me retorna de outro lugar."778 Resisto em resposta, à resposta. Respondendo ao outro. Ele tem a tendência a se tomar como os outros o tomam. Tendência. Trop tendance. Uma vez que, "em suma, eu me tomo por alguém que antes de tudo "responde", se sente convocado a responder." 779 No sentido de responsabilidade jurídico, moral, político, filosófico, psicológica mas também no sentido "daquilo que a gente chama em inglês a responsividade [responsiveness] este tipo de predisposição [...] a dizer espontaneamente "sim"., 780 Vimos como a questão da responsividade, do sim sim e da responsabilidade caminham juntas para Derrida. Desta forma, ele nos descreve, ele se toma por alguém que é convocado a esta responsividade, a este engajamento, esta aquiescência à. Respondendo ao chamado, do outro, à herança enviada e reenviada ao outro, pelo outro. Neste sentido, ele continua, nos confessa que nunca teria dito nada ou escrito nada que não fosse a princípio desejado, demandado, comandado, provocado, etc... pelo outro. "Nunca publiquei nada espontaneamente de mim mesmo." ${ }^{, 781}$ Derrida parece reconhecer a importância do que lhe é herdado, demandado, reenviado. Ele nada seria, faria, escreveria, se não tivesse sido chamado, intimado a responder. Estamos e herdamos a partir dos outros uma gigantesca herança. Seguindo os rastros do que fazia, escrevia, dizia, resiste e desdobra algo que nunca foi dele. Não esqueçamos que qualquer possível anamnese sobre esta memória herdada acenará para uma memória esclerosada. Uma memória que não se lembra da onde veio. Confessando que nunca publicou nada por ele-mesmo, Derrida nos descreve a importância dos reenvios, das demandas, dos chamados a responder, intimando-o às respostas. A alguém que se toma como esta predisposição à responder. Respondendo ao chamado do outro, talvez, respondamos também ao outro que me é outro, que sou eu mas não sou eu. Às promessas e aos chamados de um Derrida bebê à outro Derrida, de um Derrida

\footnotetext{
${ }^{778}$ Derrida, Le survivant, le sursis, le sursaut, In. Penser à ne pas voir, 2014, p.367

${ }^{779}$ Derrida, Le survivant, le sursis, le sursaut, In. Penser à ne pas voir, 2014, p.366 (Grifado nosso)

${ }^{780}$ Derrida, Le survivant, le sursis, le sursaut, In. Penser à ne pas voir, 2014, p.366

${ }^{781}$ Derrida, Le survivant, le sursis, le sursaut, In. Penser à ne pas voir, 2014, p.366
} 
de ontem à outro Derrida, ao Derrida que está prometido, para outro, para ele, para ele como outro.

Ao terminar a entrevista, Derrida então responde a partir de três palavras de "surenchère", que pode ser traduzido por ultrapassamento, sobrelance (enchère pode ser traduzido por lance, oferta em um leilão, por exemplo). O que estaria em jogo na palavra surenchère, seria, sobretudo, o sur, de sobre, acima de, para além de, uma hiperbolite ... "estas três palavras hiperbólicas em "sobre" [sur] (sobrevivente, adiamento, sobressalto) [survivant, sursis, sursaut]." ${ }^{, 782}$ Estas três palavras são de difícil tradução, especialmente as últimas duas. Por exemplo, num texto que carrega entrevistas entre Derrida, Jean-Luc Nancy e Philippe LacoueLabarthe, intitulado For Strasbourg : conversations of friendship and philosophy: Jacques Derrida traduzido por Pascale-Anne Brault e Michael Naas, eles traduzem sursis por suspensão [suspension], todo adiar e prorrogar é de algum modo suspender, suspender o encontro que foi adiado, a resposta que foi prometida. Uma suspensão que não para em neutralidade, mas que como já acentuamos uma suspensão, epokhé angustiante, que "só poderia ser motivado, só pode encontrar seu movimento e seu elã (um elã que, por sua vez, não pode ser suspenso) na exigência de um aumento ou de um suplemento de justiça."783 A suspensão carregaria consigo a noção de adiamento, prorrogação, aumento, suplementação. Ainda os mesmo tradutores das entrevistas For Strasbourg traduzem sursaut por surpresa [surprise], uma surpresa traria um sobressalto. Derrida no texto Living-on: Border Lines ${ }^{784}$ publicado inicialmente em inglês e depois em francês com o título de Survivre em Parages a partir do tradutor James Hulbert, no lugar de sursaut, se utiliza do sudden surge [surgimento repentino] e do "start" [começo] entre aspas ao lado do sursaut entre colchetes e para sursis ele se utiliza da palavra reprieve, adiamento, prorrogação.

Derrida nesta entrevista, Le survivant, le sursis, le sursaut, ao falar que respondeu à questão que nunca morreu nele - "quem é este "eu" que é ou permanece [reste] um outro, além daquele que se acha assim "tomado", cativo (não cativado, mas capturado), definido, determinado por uns e outros?" 785 - a

\footnotetext{
${ }^{782}$ Derrida, Le survivant, le sursis, le sursaut, In. Penser à ne pas voir, 2014, p.367

${ }^{783}$ Derrida, Força de lei: o fundamento místico da autoridade, 2007, p.39

${ }^{784}$ Derrida, Living-on: Boderlines In. Deconstruction and criticism, 1979, (pp.75-176) p.108, p.114, p.117, p.123 (sursaut), e p.108, p.122 (sursis)

${ }^{785}$ Derrida, Le survivant, le sursis, le sursaut, In. Penser à ne pas voir, 2014, p.366
} 
partir de estratégias de compromisso onde ele aponta a surpresa (sursaut, faire sursaut), onde os outros [on] acreditam o tomar (tomar Derrida), assumindo a responsabilidade de corresponder, consertando de uma maneira ou de outra, aquilo que os outros [on] acreditam que eu (Derrida) sou e devo ser. A surpresa e o sursaut nesta passagem caminham juntos, surpreender parece acenar para um fazer sobressaltos (faire sursaut), um começo (“start”) como recomeço, como um surgimento repentino (sudden surge). Derrida responde a questão resistindo (assumindo e consertando) com recomeços (sobressaltos) em relação ao modo como os outros o tomam.

As três palavras hiperbólicas como pudemos perceber são de difícil tradução e devem ser pensadas juntas, em diálogo uma com a outra. Tentaremos desdobrar um pouco mais, com o intuito de compreendê-las dentro desta entrevista de Derrida. Para a palavra Sobrevivente (survivant), o autor nos descreve que o sobreviver não seria "nem a vida nem a morte, antes deles, o rastro e a espectralidade." ${ }^{786}$ A sobrevivência, bem como as palavras que estamos tentando desdobrar aqui carregam consigo este sobre (sur) que nos aproxima da noção de transbordamento, de para além, de excesso, de sobra, de resto, de rastro. $\mathrm{Na}$ medida em que se algo não se presentifica, se ele é rastro de rastro, como vimos, ele seria sempre excesso transbordante, re-marcando, o que antes parecia borda. Derrida confessa, dessa forma, que ele é um sobrevivente em adiamento/prorrogação (sursis), como todos ${ }^{787}$.

Vamos recorrer ao texto Survivre (1979/1986) em Parages ${ }^{788}$ para tentar nos aproximar destas três palavras. Os termos sursis e sursaut são trazidos de modo breve, dificultando nosso desdobramento. Logo no início do texto, Derrida vai trabalhar sobre a noção da borda de um texto. Para ele uma borda nunca é assegurada, um contexto nunca se deixaria saturar. Toda borda é regularmente submergida, perdendo-se de vista a linha que delimitava um texto e seu fora. Como já vimos, não haveria fora texto. É por isso que um texto acena para constantes reenvios referencias, para o rastro, como ele mesmo descreve. Todo

\footnotetext{
${ }^{786}$ Derrida, Le survivant, le sursis, le sursaut, In. Penser à ne pas voir, 2014, p.367

${ }^{787}$ Derrida, Le survivant, le sursis, le sursaut, In. Penser à ne pas voir, 2014, p.367

${ }^{788}$ Este texto dialoga, sobretudo, com Blanchot, este diálogo não será trabalhado nesta pesquisa. Nosso intuito é tentar desdobrar estas três palavras trazidas pelo autor como resposta à pergunta "Pour qui vous prenez-vous?"
} 
texto que pretende, que deseja uma borda, uma aresta (arête), de parada ${ }^{789} / \mathrm{de}$ sentença $^{790}$ (arrêt) acaba apagando-as e reelaborando-as, são as marcas e remarcas. O transbordamento e o apagamento. A borda acaba sendo uma dobra, como uma invaginação sem fim. "Invaginação é a dobra interna da bainha, a reaplicação invertida da borda externa ao interior de uma forma onde o fora abre então um bolso. Uma tal invaginação é possível desde o primeiro rastro. É por isso que não existe 'primeiro' rastro." ${ }^{791}$ É possível vermos a relação deste transbordamento apagamento, desdobramento da dobra das bordas, com a suplementação e a desconstrução, com o sobre de um sobrevivente. Sobreviver como suplemento ${ }^{792}$ e sobrevivente como fantasma ${ }^{793}$, nos descreve Derrida. Na sobrevivência, este sobre está entregue ao enigma desta lógica do suplemento, sobrevivência como assombração, como espectralidade, rastro, suplementando de sursaut (sobressaltos, supresas, "começos") e de sursis (adiamentos, suspensões, prorrogações), colocando fim a uma sentença/parada (arrêt) decisiva ${ }^{794}$, a uma pretensa aresta. Acena para o limite como ângulo de instabilidade sobre o qual é impossível se instalar, se parar/sentenciar ${ }^{795}$ (arrêter). Uma sentença ou parada não seria apenas a decisão parando um indecidível, parando, por exemplo, o rastro, mas ela para também a morte, não deixando a morte se dar totalmente. $\mathrm{Ou}$ seja, aquilo que tenta parar o rastro, seria, por exemplo, a noção de presença ou de identidade. Ela (sentença) para a morte, suspendendo a morte, podemos pensar aqui na noção do sursis, em que prorrogando a morte, adiando, ela não se fecha, não se conclui, é prorrogada. Ela (sentença/parada) suspende a morte, interrompendo ou a diferindo no sobressalto, na surpresa (sursaut) de uma vida ${ }^{796}$. Sobressalto inesperado acena para ressurreição ${ }^{797}$, "começo" como recomeço. Fazendo a surpresa (faire le sursaut) como nos diz Derrida na entrevista, ressurge, retorna, re-marca. Um sobreviver sobre uma linha do sobre que não seria nem uma oposição (de um corte) nem uma adequação estável. Ele (o sobreviver)

\footnotetext{
${ }^{789}$ Derrida, Survivre, In. Parages, 1986, p.179

${ }^{790}$ Derrida ao longo do texto vai desdobrar as palavras aresta (arête), (arrête) parar/sentenciar, não vamos desenvolver esta relação. Deve-se compreender que uma pretensa parada definitiva, como uma borda ou uma aresta é indefinidamente dobrada, ultrapassada, sobre passada, sobre.

${ }^{791}$ Derrida, Survivre, In. Parages, 1986, p.143

792 Derrida, Survivre, In. Parages, 1986, p.153

${ }^{793}$ Derrida, Survivre, In. Parages, 1986, p.182

${ }^{794}$ Derrida, Survivre, In. Parages, 1986, p.153

${ }^{795}$ Derrida, Survivre, In. Parages, 1986, p.154

${ }^{796}$ Derrida, Survivre, In. Parages, 1986, p.159

${ }^{797}$ Derrida, Survivre, In. Parages, 1986, p.161
} 
difere, como a diferança, além da identidade e da diferença ${ }^{798}$. O que suspende por um lado e retém por outro, não acenaria assim para a dinâmica da desconstrução? Derrida inicia o debate na universidade de Villanova nos descrevendo esta tensão característica da desconstrução. A desconstrução é feita "não como uma mistura, mas a tensão entre memória [...] a preservação de algo que nos foi dado, e ao mesmo tempo, a heterogeneidade, algo absolutamente novo, e uma quebra." ${ }^{\text {799 } \mathrm{A}}$ tensão característica de seu pensamento ${ }^{800}$, como ele nos diz, faz da desconstrução um trabalho de análise que buscaria encontrar a heterogeneidade no próprio corpo do texto, não sendo, dessa forma, um método que vem de fora mas algo que acontece e que acontece dentro ${ }^{801}$. Não é de certo modo isso que Derrida nos descreve acerca da desconstrução na passagem já citada:

os movimentos de desconstrução não solicitam as estruturas do fora. [Mas] só são possíveis e eficazes, só ajustam seus golpes se habitam estas estruturas. [...] operando necessariamente do interior, emprestando da estrutura antiga todos os recursos estratégicos e econômicos da subversão, emprestando-os estruturalmente, isto é, sem poder isolar seus elementos e seus átomos, o empreendimento de desconstrução é sempre, de um certo modo, arrebatado pelo seu próprio trabalho. ${ }^{802}$

Este parágrafo teve a intenção de desdobrar as palavras que Derrida nos apresenta como resposta à pergunta na entrevista "Pour qui vous prenez-vous?". Como sobrevivente, não como se costumava pensar na imprensa de uma geração de pensadores de $68^{803}$, ele sobrevive como rastro, como espectro, espectros de Derrida. Não é também de algum modo que ele e Heidegger sobrevivem aqui neste texto?

Como adiamento (sursis), na entrevista, ele nos $\operatorname{diz}^{804}$, que por economia, como sempre, acumula as contradições: por um lado os que acreditam que ele pertenceria a uma geração de já mortos, a uma sobrevida curta a partir daquilo que ele deixaria. Por outro ele descreve nem ter começado a escrever e que nós, salvo exceções, nem começamos a lê-lo, o porvir dura longo tempo. Ele, como Derrida, estaria, de algum modo, prorrogando, adiando Derrida num porvir que é sempre

\footnotetext{
${ }^{798}$ Derrida, Survivre, In. Parages, 1986, p.179

${ }^{799}$ Caputo, J. (ed.) Deconstruction in a nutshell. A conversatiom with Jacques Derrida, 1997, p.6

${ }^{800}$ Caputo, J. (ed.) Deconstruction in a nutshell. A conversatiom with Jacques Derrida, 1997,

${ }_{801}^{\mathrm{p} .8}$ Caputo, J. (ed.) Deconstruction in a nutshell. A conversatiom with Jacques Derrida, 1997, p. 9

${ }^{802}$ Derrida, Gramatologia, 2004, p.30

${ }^{803}$ Derrida, Le survivant, le sursis, le sursaut, In. Penser à ne pas voir, 2014, p.368

${ }^{804}$ Derrida, Le survivant, le sursis, le sursaut, In. Penser à ne pas voir, 2014, p.368
} 
relacionado ao incalculável, à surpresa e com isso ao sobressalto (sursaut).

Como sobressalto (sursaut) ele descreve que é nas contradições, acumulando-as como a que ele acabou de citar descrevendo sursis, que ele encontra sua repercussão, seu chamado antes do salto (saut), com o sentimento desabusado e louco de esperança que de ainda não ter começado... Um recomeço é também uma surpresa, um sobressalto. As três palavras de difícil descrição e desdobramento caminham juntas, como pudemos ver entre as contradições, para os outros e pelos outros, Derrida, talvez, sobreviva, surpreenda (sobressalte) e adie. Em remarcações, rastros daquilo que ele nunca foi, mas que promete. Talvez seja isso que ele tentou nos descrever quando disse que ainda não começamos a lê-lo e que ele ainda não havia começado a escrever. Numa mistura de contradições entre começos e fins, re-começos de um lado e sua curta sobrevida de outro, ele desdobrou um pouco as palavras que responderiam a seu [pris], ao seu modo de ser tomado, ao rastro de como ele se toma. Na entrevista For Strasbourg : conversations of friendship and philosophy: Jacques Derrida, Derrida confessa:

o desejo que alguma coisa sobreviva, seja deixada, transmitida - uma herança ou algo que eu mesmo não aspiro, que não voltará para mim, que eu não receberei, mas que, talvez, continuará ... E isto $[c ̧ a]$ é um sentimento que me assombra não somente para o que chamamos obras e livros, mas para tudo que é banal, gestos cotidianos que foram testemunhados por isto e que manterão a memória disso quando eu não estiver mais aqui. ${ }^{805}$

Em outra passagem podemos ver estas noções em jogo, onde de alguma forma a sobrevivência, o adiamento e o sobressalto aparecem como rastros de um eu.

Eu sei que existe um Eu (I), um eu (me), um ser vivo que está relacionado com si mesmo a partir da autoafecção, que pode ser um pássaro que se sentirá vivo como eu (me), e que pode mesmo dizer, em silêncio, eu (me), e que será $e u(m e)$ ! Existirá um ser vivo que continuará a dizer eu (me) e isto será um eu (me), isto será eu (me)! Eu poderia dar outros exemplos. Mas não me sinto muito confortável nisso. $^{806}$

Não seria, talvez, esta resposta que continua aqui neste texto e talvez em outros, se prometendo, sobrevivendo, prorrogando e surpreendendo. Dando, talvez, marcas para re-pensarmos o dito humano, a dita relação com o humano, a

\footnotetext{
${ }^{805}$ Derrida, For Strasbourg : conversations of friendship and philosophy: Jacques Derrida, 2014, p. 23

${ }^{806}$ Derrida, For Strasbourg : conversations of friendship and philosophy: Jacques Derrida, 2014, p.26
} 
dita psicoterapia e as ditas ciências humanas. Re-marcadas e re-pensadas não apenas nas universidades, mas a todo tempo a partir de quais rastros? De quais marcas? Dos discursos que prometem qual promessa? São muitos textos. Aqui deixo (deixamos) de tentar seguir muitos rastros. Seria impossível seguir todos. Até por que suas marcas não são seguras, sempre posso me surpreender. No consultório o caminho segue um faro semelhante com aquele que discursa sobre um si que nunca foi um mesmo, mas uma restância que resta num rastro de rastro. O chamado de um outro intima, convoca, talvez, outros caminhos, outras formas de caminhar, surpresas, outros outros. E não será isso em jogo numa possível psicologia que levasse em consideração o rastro, a diferança e a desconstrução?

Neste sentido, podemos apontar certa esperança no discurso de Derrida e que ao recebermos o envio, reenviamos a outros algo desta esperança.

Penso naqueles que hoje gostariam de reconstruir um discurso sobre o sujeito que não seja predescontrutivista, sobre um sujeito que não tenha mais a figura da maestria de si, da adequação a si, centro e origem do mundo etc., mas que definiria o sujeito acima de tudo como a experiência finita da não identidade a si, como a interpelação inderivável, já que ela vem do outro, do rastro do outro, com os paradoxos ou as aporias do ser-diante-da-lei etc. Talvez reencontremos esse fio mais adiante. ${ }^{807}$

Este capítulo veio nos mostrar em que medida um sujeito no curso da tradição e isto incluiria o que nos interessa aqui, o pensamento de Heidegger, teria não liquidado o sujeito, mas reinscrito, revalorizado, prometido um sujeito (re)pensado a partir de um lugar mais radical, mais essencial e mais verdadeiro. Já havíamos de alguma forma apontado esta questão no texto Os fins do homem, mas em Il faut bien manger ou le calcul du sujet Derrida vai acenar justamente para esta promessa, re-marcação, re-pensamento a partir do qual um sujeito mesmo pode se formar. Num processo indefinido de reinscrição fantasmática da identidade, o que acena para o próprio processo do rastro. Herdando uma memória, uma tradição somos constantemente intimados a respondê-la, prometendo, re-marcando a memória. Reafirmando e deslocando, neste processo desconstrutivo de engajamento cuja resposta como responsividade está desde sempre em jogo. Não há como não responder a isto que me é enviado e neste sentido, talvez, possamos pensar esta responsividade mesma como o que responde por um quem. Mas ao responder já estamos de algum modo violentando, traindo,

${ }^{807}$ Derrida, Il faut bien manger ou le calcul du sujet In. Points de suspension. 1992, p.280 
traumatizando, suplementando e prometendo a memória que nos foi herdada. É nesta compulsão por "encontrar", sentenciar o sujeito que ele mesmo vem se auto afirmar, se prometer. Uma promessa que nunca se alcança. Promessa desde sempre traída. Promessa da memória, memória da promessa. Não se trata, dessa forma, de reposicionar o sujeito novamente, mas de analisar a maquinária conceitual que nos permitiu falar de algo como o sujeito até agora. É neste sentido que se desconstrói os discursos naturalizantes, óbvios, originários, próprios, ontológicos, fantasmas da apropriação sempre em jogo nos fenômenos históricos e nos discursos com e em relação ao humano. É nesta análise, neste desdobramento e desconstrução que se pode pensar algo como uma resistência com relação a este mecanismo apropriativo, sacrificial, carno-falogocêntrico. Sacrificar o sacrifício seria talvez resistir a apropriação interiorizante do outro como outro. Resistir é, talvez, manter-se nesta tensão craacterística do pensamento de Derrida. Come-se o outro, mas então como se deve comer? Lei de hospitalidade infinita, compartilhada, hospedando e nomeando os monstros que deixam de se mostrar, o outro que perde sua alteridade ao ser incluído, é aí neste lugar que se pode, talvez, resistir, analisar os discursos que se auto prometem mais fálicos, mais verdadeiros, mais puros, mais. $\mathrm{O}$ desejo de presença é inscrito na estrutura da promessa como estrutura da própria linguagem como escritura.

Neste jogo infinito de remessas, jogo da diferança e do rastro, que estamos engajados, respondendo, prometendo confirmar o que nos foi herdado, a memória do dizer sim-eu e a promessa do dizer-sim-eu, nesta dobra, dupla do sim sim, repetição indefinida, que se corta na promessa do inaugural, do pretensamente único, esquecendo a memória, respondendo e prometendo confirmar novamente de modo pretensamente inaugural, sim-eu. Este lugar da resposta é também da responsabilidade, não de uma auto conquista ou de uma autonomia, mas o que está em jogo nesta responsividade responsabilidade é a surpresa, o injustificável e o excesso de toda decisão. Que não se decidiria sobre algo já calculado e planejado, já sabido, mas partindo daquilo que não se sabe, da própria impossibilidade de saber (compreender). Podemos talvez dizer que um eu come e interioriza a memória que lhe foi destinada, respondendo e prometendo a confirmar, no mesmo lance ele a esquece, promete e deseja o único, desloca, traduz, transforma, nesta indefinida descontrução que este eu achava que era eu. Este eu jamais pode ser encontrado, apreendido, conquistado, numa pretensa 
autonomia ou essência, uma vez que toda origem natural, ontológica, pura se auto disse, ela não pode não dizer esta apropriação senão no decurso de um processo não natural, não ontológico, não puro de construções político-fantasmáticas. $\mathrm{Na}$ promessa do eu e no eu que me foi entregue haveria um entre e é aí, talvez, que aconteça a decisão e a responsabilidade. Toda regra, cálculo e pretenso saber seria assombrado pelo indecidível. Diante deste não saber, de um tal indecidível, impossível, do Outro como outro é que se pode responsabilizar. No momento de resposta ou decisão diante de qualquer radicalmente outro estamos entregues ao segredo de não se sabe o que, da solidão e do paradoxo do sacrifício: comemos, damos a morte uns e não comemos outros, justicativa impossível. É a partir deste paradoxo, desta tensão, deste entre, nem verdade, nem falsidade que a desconstrução do dito humano poderia se tecer.

É neste sentido que Derrida insiste sobre a heterogeneidade, a dissociação de tudo. Insiste sobre aquilo que impede que a unidade se feche. Assim uma identidade de uma cultura ou de um humano, poderíamos dizer, é um modo de ser diferente dele mesmo, uma pessoa é diferente dela mesma. Ela é aberta a uma outra identidade. Isto é o que previne o totalitarismo, o egocentrismo, por exemplo. É porque eu não sou um comigo mesmo que eu posso falar com o outro e endereçar-me ao outro. Quando se dá privilégio para a reunião, como seria o caso do discurso heideggeriano ao pensar a unidade do Dasein e algo comum que perpasse a Historia do ser, não acenando, assim para a dissociação radical. O que acontece com as pretensas reuniões, unificações, verdades é que não se deixa espaço para o outro, para o que está fora, para a radical outreidade, para a radical singularidade do outro. Não seria isso de certo modo que deveria estar em jogo num pensamento acerca do humano? Acerca da loucura, por exempo? Certo "acolhimento", respeito, análise e atenção para o que está fora? Para o Outro como Outro? Para aquilo que não se sabe?

Incluindo o outro damos a palavra ao estrangeiro, ao monstro, ao outro, perdendo-o de vista. Estrutura hospitaleira, violenta, traumatizante indefinidamente. Um hospedeiro que pode, que usurpa com seu poder ja estaria em jogo na ipseidade de um pse. Algo me foi dado, não é meu, não é de quem me deu, não há origem encontrável, é meu e não é meu. Jogo do entre, estrutura antinômica na qual tecemos nossos caminhos. Impossível Necessário. Paradoxo desta necessidade de querer confirmar a promessa e a impossibilidade de realizá- 
la. Talvez possamos pensar que sempre um humano será chamado a falar sobre o humano, uma vez que não há o humano. Ele caminha neste paradoxo mesmo. Desejando e prometendo a si mesmo, a reconstituição de sua memória desde sempre apagada, ele transborda e apaga aquilo que ele pensava ser ele. Nesta constante reapropriação do que acredita ser si mesmo, nesta hiperbolite aguda de se auto dizer humano, este dito humano ou sujeito caminharia, talvez, em pequenas pausas, se deslocando e se dividindo ao se reunir para responder ao outro. E por isso Derrida ao responder a pergunta por quem você se toma? Nos descreve que ele se toma como os outros lhe tomam, lhe enviam, resistindo ao mesmo tempo aos reenvios dele pelo outro. Respondendo e resistindo aquilo que os outros acreditam que ele é e deve ser. Ele diria, resisto em resposta, à resposta. Respondendo ao outro. Assim ele nos diz, "em suma, eu me tomo por alguém que antes de tudo "responde", se sente convocado a responder." ${ }^{\text {"808 }}$ Respondendo, ele herda e reenvia, num processo indefinido de transbordamento e apagamento do que lhe foi enviado, herdado pelo outro e para o outro. Assim, neste entre paradoxal, ele desconstrói, ultrapassa, sobrepassa, sobrevive, sobressaltando e surpreendendo em recomeços, prorrogando o que nunca tem como chegar. A desconstrução é feita, e aqui podemos pensar com relação ao humano e na relação com o humano, "não como uma mistura, mas a tensão entre memória [...] a preservação de algo que nos foi dado, e ao mesmo tempo, a heterogeneidade, algo absolutamente novo, e uma quebra." ${ }^{809}$ É neste sentido que talvez possamos desdobrar isto que chamamos de humano, que nos foi entregue, herdado como humano, desconstruindo, re-afirmando, re-marcando e re-pensando a partir da diferança e do rastro. Assim, podemos, talvez pensar uma (im)possível psicologia levando em consideração o que desdobramos como rastro e diferança. Talvez reencontremos esse fio mais adiante.

\footnotetext{
${ }^{808}$ Derrida, Le survivant, le sursis, le sursaut, In. Penser à ne pas voir, 2014, p.366 (Grifado nosso)

${ }^{809}$ Caputo, J. (ed.) Deconstruction in a nutshell. A conversatiom with Jacques Derrida, 1997, p.6
} 


\section{(In)conclusão}

Foi possível ao longo desta pesquisa costurarmos e desdobrarmos dois grandes pensadores: Martin Heidegger e Jacques Derrida, tendo em vista o repensar acerca do humano. Repensá-lo na medida em que ele muitas vezes é tomado como algo objetivável, como uma unidade identificável, em que seus limites pudessem de algum modo ser determinados. Estes pensadores surgem em momentos distintos para alargar, destruir e desconstruir tais limites.

Pudemos repensar com Heidegger este humano a partir do Dasein e da sua essencial abertura ao ser, abertura esta central para destruirmos as bases tradicionais que sustentavam o humano moderno como algo coisificável e objetivável. Esta abertura que tem como marca a diferença ontológica neste ente pode ser apropriada a partir de uma abertura privilegiada - a angústia - dando espaço para a singularização deste ente a partir de um modo de ser mais próprio, onde ele se apropria de sua essência como unidade total do cuidado, como serresoluto antecipador da morte, se conquistando como ser responsável pelo seu poder-ser-no-mundo e livre para sua possível e cada vez retomada de sua propriedade. Como modo possível ele também pode se perder no modo impróprio cotidiano. Esta analítica do Dasein revela os elementos característicos da essência do que chamamos de humano. O que acaba acontecendo nesta obra é que pela singularização do Dasein, a apropriação de sua unidade, de sua abertura poderia se dar uma transformação de mundo. Peso este, que como vimos Casanova nos esclarece, ele seria incapaz de suportar ${ }^{810}$. Assentar a transformação de mundo sobre o Dasein teria obrigado Heidegger a revisar este lugar dando margem a noção de acontecimento apropriador e de destinos do ser. Nosso objetivo não foi de modo algum repensar as transformações de mundo em Heidegger. Mas repensar o humano a partir do pensamento deste autor. Neste sentido, com o pensamento dos destinos epocais e da História do ser, o Dasein humano ganha outro papel. Ele não teria perdido seu caráter existencial nem sua unidade como cuidado, como pudemos ver em Sobre o humanismo. Mas haveria certo deslocamento da diferença ontológica, que deixa de ser pensada apenas a partir do

${ }^{810}$ Casanova, Fenomenologia hoje IV: fenomenologia, ciência e técnica. 2013. p.275-276. 
Dasein e passa a ser pensada a partir do Da. O próprio mundo passa a ser pensado a partir desta diferença.

Neste sentido, começamos a pensar este lugar do Dasein a partir de obras mais tardias, tentando compreendê-lo junto aos elementos que foram aprofundados nesta nova etapa. Dessa forma, a linguagem como a casa do ser e acolhimento do pensar (do ser) entram em jogo a partir do que Heidegger chamou de esvaziamento da linguagem e do pensar que ameaçariam a própria essência do homem. Em Sobre o humanismo o autor alemão vai buscar apontar para a necessidade do homem de compreender sua essência, o pensar e a linguagem do ser que acenariam para os destinos epocais. Nesse sentido, desumanizado e esvaziado o homem se encontraria perdido de sua essência e deve de algum modo tentar conquistá-la. Heidegger parece acenar para a possibilidade de "levar a essência do homem a atentar, com seu pensar, para a dimensão da verdade do ser" ${ }^{\prime 11}$, experimentando a dignidade do homem, penetrando na clareira do ser, ele vigia e protege, sendo assim pastor do $\operatorname{ser}^{812}$. Ele acrescenta, vigiar e proteger a clareira do ser acena para o homem como "o pastor do ser. É somente nesta direção que pensa Ser e Tempo, quando é experimentada a existência ecstática como “o cuidado" (vide $\S 44$, p.266 ss.)." ${ }^{813}$ Esta experiência aponta para a proximidade do homem e do ser, como verdade do ser, uma vez que desumanizado, o homem se encontra abandonado, esquecido do ser, só pensando o ente. $\mathrm{O}$ modo como o ente se presenta e ausenta não decide o homem, mas o que está em jogo é o modo como o ente penetra na clareira do ser. "O advento do ente repousa no destino do ser." ${ }^{, 814}$ E por isso, "a história do ser sustenta e determina cada condition e situation humaine." ${ }^{\text {815 }}$ A relação ser e homem (humano) continua imbricada pelos destinos historiais. Nesse sentido, Heidegger nos diz que "pensar a verdade do ser significa, ao mesmo tempo: pensar a humanitas do homo humanus. $"{ }^{816}$ Onde o pensar sulca a linguagem do ser de modo invisível, destinal e historial a partir do dizer dos pensadores.

Acenando para este esvaziamento da linguagem e o abandono do ser, do pensar e da essência do homem, Heidegger em diálogo com os psiquiatras e

\footnotetext{
${ }^{811}$ Heidegger, Sobre o humanismo 1973 , p.355

${ }^{812}$ Heidegger, Sobre o humanismo 1973, p.356

${ }^{813}$ Heidegger, Sobre o humanismo 1973, p.356

${ }^{814}$ Heidegger, Sobre o humanismo 1973, p.356

${ }^{815}$ Heidegger, Sobre o humanismo 1973, p.347

${ }^{816}$ Heidegger, Sobre o humanismo 1973, p.367
} 
psicoterapeutas trabalha em cima da necessidade de conquistar este espaço abandonado. Refletindo sobre a impossibilidade de objetivar o humano, de calculá-lo e de mensurar as possíveis patologias determinadas a partir de um horizonte histórico. Heidegger coloca em xeque este modo de mensuração e cálculo característico e herdado da época moderna que tinha o humano como objeto de cálculo e a verdade como adequação e conformidade. Nesse sentido, ele passa a repensar a ciência e sua pretensão de verdade absoluta, acena para a essência do homem ameaçada neste horizonte, apontando também para outras formas possíveis de presentificação do ente, de interpretação do ser do ente. Fica claro o motivo do apelo de Heidegger para aqueles que se relacionam com os humanos enfermos, enquanto eles tiverem abandonado o ser, "manterão" a linguagem esvaziada e o homem desumanizado, é necessário que eles se situem historicamente e tenham a experiência de compreenderem-se a si mesmos como Dasein $^{817}$. Para os herdeiros da ciência moderna, se deixada à seu destino, culminará na autodestruição do homem ${ }^{818}$. Assim ele nos descreve:

Quem se dedica hoje em dia à profissão de ajudar as pessoas psiquicamente enfermas, deve saber o que acontece; deve saber onde está historicamente; precisa esclarecer-se diariamente que aqui está operando um destino antigo do homem europeu; ele precisa pensar de maneira histórica e abandonar a absolutização incondicional do processo em cujo rastro o ser-homem do homem ocidental ameaça sucumbir. ${ }^{819}$

É a partir do pensamento da História do ser que Heidegger vai pensar a história da metafísica como constituição onto-teológica. E a diferença ontológica como aquilo que separa e mantém ente e ser como fenômenos, separando-os e unindo-os em constituições específicas ao longo da História do ser. A proximidade com este cunho Epocal se daria por uma lembrança [da diferença], "para a experiência de cada cunho da diferença do ser do ente ao qual corresponde uma interpretação do ente enquanto tal" ${ }^{820}$, como physis, lógos, hén, idéa, enérgeia, substancialidade, objetividade, subjetividade, vontade, vontade de poder, vontade de vontade ${ }^{821}$. É pensando nas diferentes interpretações do ente

\footnotetext{
${ }^{817}$ Heidegger, Seminários de Zollikon, 2001, p.236

${ }^{818}$ Heidegger, Seminários de Zollikon, 2001, p.121

${ }^{819}$ Heidegger, Seminários de Zollikon, 2001, p.129 (Grifado nosso)

${ }^{820}$ Heidegger, A constituição Onto-teo-lógica da Metafísica In. Identidade e diferença, 1973, p. 397

${ }^{821}$ Heidegger, A constituição Onto-teo-lógica da Metafísica In. Identidade e diferença, 1973, p.397
} 
enquanto tal, dos destinos historiais, que Heidegger pensa que "talvez se manifeste mesmo pela discussão da diferença de ser e ente, na de-cisão [na diferença], algo comum, que perpassa o destino do ser desde o começo até sua plenitude" ${ }^{822}$. O que deve ser lembrado é a diferença ontológica que estava esquecida durante todo o edifício da metafísica ${ }^{823}$. Assim, Heidegger propõe o passo de volta, como o passo do pensamento que pensa a diferença esquecida e a essência da metafísica como constituição onto-teológica, bem como o desvelamento e o velamento dos destinos epocais. O passo de volta pode tornar-se autêntico dando espaço para pensar o que ele chama de acontecimento apropriação [Ereignis]. "Heidegger coloca então o acento sobre o retiro do ser e se dirige até um pensamento do Ereignis, do acontecimento apropriando o homem e o ser. ${ }^{~} 824$ Onde há um pertencer recíproco a partir do qual homem e ser recebem as determinações de sua essência, que foram compreendidas pela filosofia. O próprio acontece agora quando no acontecimento apropriador o homem recebe o seu próprio a partir do acontecimento mesmo, deixando-se se apropriar por ele ${ }^{825}$. Assim, ser e homem atingiriam suas essências e conquistariam seu caráter historial, perdendo aquelas determinações que a metafísica lhes emprestou ${ }^{826}$. É nesse sentido que Dastur nos descreve como depois da virada, Heidegger tenta pensar "a diferença não mais achando sua origem na transcendência do Dasein, mas como uma dimensão pertencente ao ser mesmo, como esta dupla dobra do ser e do ente que os torna inseparáveis um e outro." ${ }^{~} 827$ Ela nos diz como Heidegger vai pensar o retiro do ser que advém ao mesmo tempo e com a aparição do ente, o ser mesmo é pensado como proveniente da diferença ${ }^{828}$. E não mais como presença daquilo que é presente, a entidade ${ }^{829}$. Quando o salto [pelo passo de

\footnotetext{
${ }^{822}$ Heidegger, A constituição Onto-teo-lógica da Metafísica In. Identidade e diferença,1973, p.397. (Grifado nosso).

${ }^{823}$ Heidegger, A constituição Onto-teo-lógica da Metafísica In. Identidade e diferença, 1973, p.399 e Carneiro Leão, Itinerário do pensamento de Heidegger In. Introdução à metafísica, 1999, p.13

${ }^{824}$ Dastur, Heidegger, Derrida et la question de la différence, In. Derrida, la tradition de la philosophie, 2008, p.101

${ }^{825}$ Casanova, M. Pensamento em transição: Heidegger e o outro início da filosofia In. Fenomenologia hoje IV: fenomenologia, ciência e técnica, 2013. p.278

${ }^{826}$ Heidegger, O princípio da identidade In. Identidade e diferença, 1973, p.383

${ }^{827}$ Dastur, Heidegger, Derrida et la question de la différence, In. Derrida, la tradition de la philosophie, 2008, p.102

${ }^{828}$ Dastur, Heidegger, Derrida et la question de la différence, In. Derrida, la tradition de la philosophie, 2008, p.103

${ }_{829}$ Dastur, Heidegger, Derrida et la question de la différence, In. Derrida, la tradition de la philosophie, 2008, p.101
} 
volta] salta "na diferença ontológica, o fundamento não é mais pensado como a condição incondicionada, como a presença absolutamente constante do ser, mas como 'acontecimento apropriador'. ${ }^{830}$ A passagem a seguir nos esclarece ainda mais acerca da Ereignis:

O essenciar-se do ser se articula de duas formas [...] ele implica a determinação do ente na totalidade [...] o descerramento [abertura] de um horizonte ontológico transcendental e globalizante do qual provém, sobretudo, a medida do "é" dos entes que se mostram nesse horizonte. Heidegger se vale do termo "clareira" (Lichtung) para designar tal horizonte, entendido como o espaço no qual o Dasein humano habita. [...] [O segundo momento do essenciar-se] O descerramento do ser do ente na totalidade não inclui somente a abertura do ente, mas também a presença de algo que resiste a essa abertura. ${ }^{831}$

Este segundo capítulo finaliza abordando e desdobrando o papel do Dasein humano e sua destruição do humanismo e do humano como metafísica e parte de uma Historia do ser. Abrimos espaço para então dialogarmos com a leitura de Derrida sobre Heidegger tendo em vista o repensar o humano. O autor francomagrebino desdobra o pensamento heideggeriano, desconstruindo, fazendo tremer a partir das próprias estruturas que nele estavam asseguradas. Derrida vai repensar os limites que asseguram uma unidade, uma reunião, uma identidade, uma proximidade, característica do que ele chama de logocentrismo, uma vez que tais limites tendem a se definir excluindo aquilo que passa então a determinar sua borda. Uma derivação e uma exclusão estariam sempre em jogo numa unidade ou em uma identidade. Estas por sua vez não teriam nenhuma base, fundamento natural ou ontológico para assegurar tais limites e bordas. O que está em jogo na desconstrução é o próprio gesto de suplementação, metaforização apagando os limites, reduzindo as praças fortes e os abrigos do fora-de-jogo. Neste sentido questionar esta reuniões totalizantes, as unidades e identidades é também questionar a autoridade de uma essência humana, de uma verdade, da presença, da formação do sentido de ser como presença e ausência nas categorias do ente ou da entidade $^{832}$.

O que Derrida desdobra e desconstrói são as noções que carregam consigo as pausas totalizantes, como as noções de verdade, ser, unidade, identidade,

\footnotetext{
${ }^{830}$ Casanova, M. Pensamento em transição: Heidegger e o outro início da filosofia In. Fenomenologia hoje IV: fenomenologia, ciência e técnica, 2013. p.285

${ }^{831}$ Casanova, M. Pensamento em transição: Heidegger e o outro início da filosofia In. Fenomenologia hoje IV: fenomenologia, ciência e técnica, 2013. p.287

${ }^{832}$ Derrida, A Diferença In. Margens da filosofia, 1991, p.41
} 
origem, pureza, essência, a possibilidade mesma de apropriação do próprio ou de qualquer uma destas noções aqui descritas. Ele mesmo acena para a possibilidade de apagamento da noção de diferança, uma vez que ela nunca governou nenhum encadeamento, nenhuma unidade rastreável, mas ela acena apenas para um rastro de rastro apagado. E por isso ele nos diz que a verdade, a pureza, o natural, o neutro foram desde sempre violentados, apagados, substituídos, há desde sempre violência. Uma errância sem destino certo, mas que atravessa como destino, destinerrância, envios que nunca chegam. O sonho de plena presença a si, característico de uma unidade, de uma identidade foi deste sempre violentado. $\mathrm{O}$ que é colocado em xeque neste gesto é o privilégio de um discurso abrigado, tranquilo, idealizado, próprio, puro, neutro numa extremidade e na prepotência de não pertencer ao jogo. Enclausurando aqueles que pertencem e reduzindo-os ao próprio discurso, limitando todo o resto e apontando o horizonte a partir do qual discursa. Este gesto, diria-se neutro para poder se auto-dizer, é o gesto também de um divino, do pai, de uma totalidade natural, da origem, da essência, da verdade, da identidade. E não é de certa forma a partir destes gestos que surgem discursos sobre o humano, repensando o humano? É a partir de uma reunião, de uma proximidade, de uma verdade que "pensou-se o ente (substância ou res) com o seu predicado essencial." ${ }^{833}$ Pensar as margens, os limites destas reuniões seria desequilibrar ${ }^{834}$, deslocar, alargar, interrogar sua pretensa homogeneidade, aparente unicidade $^{835}$. Pensar os limites seria de alguma forma pensar também a passagem, o transbordar das bordas.

O desequilíbrio só é possível, pois não há centro de referência presente, não há garantia ontológica, causal ou natural que sustente este centro. Pensar suas margens, pensar as margens que podem definir o humano, a essência do humano e aqui podemos incluir repensar o normal, o patológico, é de algum modo desequilibrar, deslocar pretensas homogeneidades. Derrida é um pensador da heterogeneidade. Ao pensar em um destino comum, algo comum, que perpassa o destino do ser desde o começo até sua plenitude. Ao pensar uma essência humana, mais humana e mais digna determinada por este destino comum. Heidegger teria ainda mantido certa homogeneidade. Derrida acena para este alargamento em

\footnotetext{
${ }^{833}$ Derrida, Os fins do homem, 1991, p.174

${ }^{834}$ Derrida, Timpanizar a filosofia In. Margens da filosofia, 1991, p.16

${ }^{835}$ Cf. Derrida, Timpanizar a filosofia In. Margens da filosofia, 1991, p.17
} 
algumas passagens, quando nos diz que haveria uma unidade, "a unidade de uma grande época do mundo, comandada pela filosofia como destino da Europa [...] Aquilo que se anunciava com Platão se precisa com o Deus da filosofia da idade média, vem a sua realização desde Descartes, Kant, Hegel [...] e a técnica moderna." 836 E quando nos descreve que o que parece acontecer é que "sua própria perda [da diferença, de cada cunho da diferença ôntico-ontológica que corresponde às épocas da História do ser] é resguardada, guardada, considerada [regardée], retardada. Num texto. Sob a forma da presença. Da propriedade. Que é, ela própria, um efeito de escritura [do rastro]. ${ }^{״ 837}$ De alguma forma, Heidegger ainda manteria uma unidade comum, homogênea, que perpassa as épocas e se realiza nos dias de hoje. Solicitando (destruindo) a evidência mais fundamental e irredutível da totalidade da metafísica, da filosofia mesma, ou seja, a presentidade da presença, Heidegger procuraria encontrar a possibilidade da própria historicidade ${ }^{838}$. Solicitando (destruindo) a época que dissimula a história do ser sobre a história da entidade como presentidade ${ }^{839}$. Heidegger para destruir a metafísica, nos descreve Derrida, deve a confirmar, só escapa do presente, da presença do presente como determinação de ser, fazendo como tema esta dissimulação do sentido de ser na presença, esta dissimulação como história, de uma forma grega de dissimulação à forma pós cartesiana ... fazendo como tema as épocas da metafísica e a metafísica como época ${ }^{840}$.

Ao pensar também a unidade e a essência do Dasein acenando para a dignidade e a verdade não teria Heidegger ainda se mantido numa certa homogeneidade? Em que medida estamos nós [quem?] fadados a este homogêneo? Derrida não colocou desta forma, mas, talvez estivesse acenando para a totalização em jogo neste pensamento quando nos diz que "o desdobramento da diferança talvez não seja apenas a verdade do ser e da epocalidade do ser." ${ }^{841}$ Sendo inominável não haveria nome a dar a ela [diferença], nem ser, nem essência, "nem mesmo o de "diferança",842.

\footnotetext{
${ }^{836}$ Derrida, Heidegger: la question de l'Être et l'Histoire, 2013, p.199-200

${ }^{837}$ Derrida, A Diferença In. Margens da filosofia, 1991, p.59

${ }^{838}$ Derrida, Heidegger: la question de l'Être et l'Histoire, 2013, p.209

${ }^{839}$ Derrida, Heidegger: la question de l'Être et l'Histoire, 2013, p. 218

${ }^{840}$ Derrida, Heidegger: la question de l'Être et l'Histoire, 2013, 217-218

${ }^{841}$ Derrida, A Diferença In. Margens da filosofia, 1991, p.56 (Grifado nosso)

${ }^{842}$ Derrida, A Diferença In. Margens da filosofia, 1991, p.62
} 
Derrida não estará mais falando de ausência ou presença, mas de um entre, um intervalo que tampouco se pode homogeneizar, mas que acena para um jogo de efeitos, de remessas sem centro de referência. Por isso a diferança não fala da diferença de duas coisas presentes, mas da diferença de reenvios, remessas diferenciais sem origem. Nesse sentido que ele nos diria para começarmos deste intervalo, do intermediário ${ }^{843}$, "é preciso começar de onde quer que estejamos e o pensamento do rastro, que não pode não considerar o faro, já nos ensinou que seria impossível justificar absolutamente um ponto de partida. De onde quer que

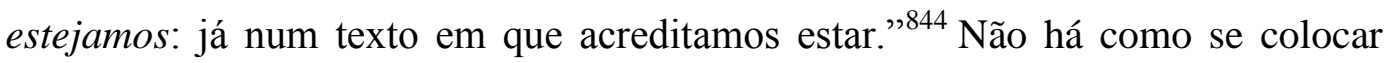
fora do jogo para dizer o que o jogo é, este é o movimento mesmo do transcendental, uma das reduções do rastro. Este não é nem reduzido ao transcendentalismo fenomenológico e nem rompe totalmente com ele. Um entre. Um quase. Um talvez. Uma tensão. Não há rompimento total. Não há fora texto $^{845}$.

Se não há a verdade, a origem, a pureza, a presença a si do texto, não significa que ela não seja sonhada, prometida, desejada, farejada. Um desejo de unidade de presença está sempre em jogo, prometido. Não seria o sujeito, o humano uma promessa? Não teria Heidegger também prometido de certa forma um "humano" (mais digno)? Uma vez que ele não teria questionado a relação irredutível homem-verdade-ser, esta teria sido apenas deslocada, a partir de uma "revalorização", Heidegger diria uma radicalização, da própria essência e dignidade do homem. O pensamento do autor alemão certamente é contra o humanismo, as determinações substancialistas e redutoras do homem, como vimos, mas proporia ainda, uma noção da humanitas do homem mais essencial e própria. Carregando consigo todas as questões éticas, políticas e acrescentamos psicológicas, intrínsecas a um pensamento do próprio, do digno, da verdade, do puro e do original, que Derrida viria justamente deslocar, acenar e fazer tremer. Tais questões são trazidas e tremidas, sobretudo, no final do terceiro capítulo intitulado Geschlecht quando abordamos a questão da neutralidade, a diferença tomada como dual, as relações originárias estabelecidas a partir do idioma alemão, do alto e antigo alemão. Assim ele nos questiona, lembremos: como

\footnotetext{
${ }^{843}$ Derrida, Gramatologia, 2004, p.192-193

${ }^{844}$ Derrida, Gramatologia, 2004, p.199

${ }^{845}$ Derrida, Gramatologia, 2004, p.194
} 
pensar a apropriação e a pertença do Gedicht (poema, no caso de Trakl, mas também do pensar do ser em Heidegger) em uma língua e em uma Geschlecht $?^{846}$ Como pensar o Dasein humano - nós - como sendo a essência de todos os homens a partir de uma Geschlecht assentada sobre o idioma alemão? Sobre o espírito determinado mais originariamente pelo idioma alemão? Nesse sentido nos perguntamos: a partir do momento que Heidegger acentua os privilégios de um povo alemão (Cf. Introdução à metafísica), de uma língua alemã (Cf. Geistlich com o sentido que daria Trakl em o Poema de Trakl), de uma decisão historial que recairia sobre um povo alemão, estaríamos nós em um discurso, talvez, fechado, em certo ponto com relação aos discursos da humanidade do humano? Seria possível pensar discursos que não estariam destinados à esta programação? A esta destinação [do ser, das interpretações do ser dos entes]?

A partir deste terceiro capítulo onde trazemos algumas das leituras de Derrida acerca do pensamento de Heidegger, passamos a pensar como Derrida poderia acenar, re-pensar este humano. É pensando nos autores que teriam liquidado o sujeito, dentre eles Heidegger, que Derrida vai acenar não para uma liquidação, mas para uma reinscrição [um re-pensar], um sujeito, talvez, prometido, desejado. Re-pensado num movimento de suplementariedade que vem re-inscrever uma essência mais digna e verdadeira do sujeito. Nesse sentido, "uma identidade nunca é dada, recebida ou alcançada, não, apenas existe o processo interminável, indefinidamente fantasmático, da identificação." 847 Como a assombração fantasmagórica dos rastros do sujeito do sujeito, do humano do humano, e acenamos para um eu do eu também inscrito nessa estrutura espectral de transbordamento apagamento.

Nessa estrutura espectral a mola da afirmação do sim sim cujo engajamento e a resposta são estruturais dizem respeito ao movimento desconstrutivo e responderia também pelo quem. Ou seja, este quem seria da ordem de uma afirmação (engajamento), de uma responsividade, que respondendo abre e reafirma o rastro do rastro. Um quem assediado pela problemática do rastro e da diferança, da afirmação, do dito nome próprio, do jet (lançado) (antes de todo

\footnotetext{
${ }^{846}$ Derrida, Heidegger's Hand (Geschlecht II) In. Psyche: Inventions of the Other vol.II, 2008,

${ }_{847}^{\mathrm{p} .60}$ Derrida, $\mathrm{O}$ monolinguismo do outro ou a prótese de origem, 2001, p.43
} 
subjet, objet, projet) como destinerrância dos envios ${ }^{848}$. Nesse sentido, este quem fala de um deslocamento constante, solicitado e tremido pelo chamado do outro. É discursando sobre o humano que ele pode ser deslocado, é porque ainda há a dizer sobre o humano que podemos reinscrevê-lo. Se o humano já estivesse sido definido, determinado em sua unidade e essência nada mais teríamos a falar sobre ele. É a partir de uma "afirmação deslocada (portanto sem "firmeza" nem "fechamento") que algo como o sujeito, o homem ou quem que seja pode tomar forma." 849

O chamado do outro intima às respostas, um chamado para o qual não posso deixar de responder, está na raiz de toda responsabilidade e decisão. Responder é estar engajado neste chamado do outro, ao outro. Somos responsáveis na medida em que respondemos e prometemos, promessa de manter a memória do sim e de confirmá-la, prometo confirmar o que disse, o eu-mim, o que me foi destinado pelo outro. Um outro que não tem nome, que não é possível controlar, calcular, medir, presentificar, determinar, mas que chama, vem a mim. A responsabilidade em Derrida acena para aquilo que não se pode apropriar, não se pode compreender, calcular, nomear. É da ordem da desmedida. O outro como este inapropriável, inominável, impossível. Nesse sentido, fica mais claro quando Derrida nos diz que “talvez seja mais 'digno' da humanidade manter alguma inumanidade. ${ }^{~} 850$ Algo de inapropriável neste humano. Responsabilizar-se diante dele seria de algum modo manter, respeitar algo de inapropriável, de "inumano" neste humano. Neste jogo de reapropriação desejada Derrida nos descreve a estrutura do sacrifício e do carno-falogocentrismo, onde os mestres, a força viril do macho, adulto, pai, marido, irmão aqui poderíamos acrescentar branco, europeu, ocidental, rico, belo, consciente dominaria o discurso acerca do sujeito. Mestres que comem a carne, se apropriam do outro, sacrificam uns em detrimento de outros. Estrutura da violência característica do pensamento de Derrida. Tal estrutura acena também para o que ele chamou de hospitalidade infinita, uns comem os outros, comilança repartida. Hábitos que não são meus, mas daquele onde me hospedo, mas também não são totalmente dele, mas do hospedeiro do hospedeiro. É talvez numa quase-resistência que ele vem re-pensar o dito humano,

\footnotetext{
${ }^{848}$ Derrida, Il faut bien manger ou le calcul du sujet In. Points de suspension. 1992, p.275

${ }^{849}$ Derrida, Il faut bien manger ou le calcul du sujet In. Points de suspension. 1992, p. 276

${ }^{850}$ Derrida, Il faut bien manger ou le calcul du sujet In. Points de suspension. 1992, p.290
} 
acenando para uma resistência à reapropriação deste outro como outro, sacrificando o sacrifício. Não é que ele deixará de existir, mas é nesta atenção, tensão, que se pode resistir. Resistência que se faz e se deve fazer diante de noções como cálculo, substância, sujeito, essência, verdade, pureza, propriedade .... acenando para os limites e critérios em que elas se apoiam.

Esta estrutura paradoxal, antinômica, de tensão, do entre é característica do pensamento de Derrida; isto fica claro quando ele nos descreve a relação promessa-memória, a desconstrução é feita "não como uma mistura, mas a tensão entre memória [...] a preservação de algo que nos foi dado, e ao mesmo tempo, a heterogeneidade, algo absolutamente novo, e uma quebra." ${ }^{851}$ Mas também quando escreve: "não há X, não há senão X." 852 "Eu não tenho senão uma língua e ela não é minha." ${ }^{\circledR 853}$ A total impossibilidade de alcançar, apropriar, compreender e o desejo e a promessa de algo como necessárias. Hiperbolite incurável ${ }^{854}$ que talvez acene para as três palavras hiperbólicas (sobrevivente, adiamento, sobressalto) [survivant, sursis, sursaut] respondidas por Derrida quando o perguntaram por quem ele se toma. Impossível necessário. Uma vez que não se apropria, ou só se apropria em pequenas pausas. Há um desejo de reconstituição, promessa anunciando a unicidade de uma língua, de uma presença, de uma identidade por $\operatorname{vir}^{855}$, mas que não chega. E por isso, haveria sempre este excesso transbordante, hiperbólico, sobre, de um sobrevivente, um suplemento, remarcando e re-pensando o que aqui chamamos de humano. A partir do fio mais adiante prometido, enviado e herdado, envio (enviamos) novamente para que deste fio outros tecidos possam se costurar.

Penso naqueles que hoje gostariam de reconstruir um discurso sobre o sujeito que não seja predescontrutivista, sobre um sujeito que não tenha mais a figura da maestria de si, da adequação a si, centro e origem do mundo etc., mas que definiria o sujeito acima de tudo como a experiência finita da não identidade a si, como a interpelação inderivável, já que ela vem do outro, do rastro do outro, com os paradoxos ou as aporias do ser-diante-da-lei etc. Talvez reencontremos esse fio mais adiante. ${ }^{856}$

\footnotetext{
${ }^{851}$ Caputo, J. (ed.) Deconstruction in a nutshell. A conversation with Jacques Derrida, 1997, p.6

${ }_{852}$ Derrida, O monolinguismo do outro ou a prótese de origem, 2001, p. 33

${ }^{853}$ Derrida, O monolinguismo do outro ou a prótese de origem, 2001, p. 13

${ }^{854}$ Derrida, O monolinguismo do outro ou a prótese de origem, 2001,p.66

${ }^{855}$ Derrida, $\mathbf{O}$ monolinguismo do outro ou a prótese de origem, 2001, p. 100

${ }^{856}$ Derrida, Il faut bien manger ou le calcul du sujet In. Points de suspension. 1992, p.280 (Grifado nosso)
} 


\section{6}

\section{Referências bibliográficas}

BENNINGTON, Geoffrey; DERRIDA, Jacques. Jacques Derrida. Tradução de Anamaria Skinner. Rio de Janeiro: Zahar, 1996.

BOSS, Medard., Prefácio à primeira edição, In. Heidegger, Seminários de Zollikon, tradução de Gabriela Arnhold e Maria de Fátima de Almeida Prado. Petrópolis: ed. Vozes, 2001.

CABRAL, Alexandre M. \& REZENDE, Jonas A redenção de Deus: sobre o Diabo e a inocência, Rio de janeiro: Via Verita, 2012

CAPUTO, John (ed.) Deconstruction in a nutshell. A conversatiom with Jacques Derrida, New York: Fordham University Press, 1997

CARNEIRO, Leão. Itinerário do pensamento de Heidegger In. Introdução à metafísica, 1999.

CASANOVA, Marco, Nada a Caminho: Impessoalidade, Niilismo e Técnica na Obra de Martin Heidegger. 1.ed. Rio de Janeiro: Forense Universitária. 2006. Compreender Heidegger, 3.ed, Petrópolis: Vozes, 2012. Pensamento em transição: Heidegger e o outro início da filosofia In. Fenomenologia hoje IV: fenomenologia, ciência e técnica. Casanova, M. \& Melo, R. F. (org.), Rio de janeiro: via verita, 2013, p.269-302.

DERRIDA, Jacques, L'écriture et la différence, Normandie: Ed. Du Seuil, 1967 Living-on: Boderlines In. Deconstruction and criticism, tradução de James Hulbert, Londres: Routledge \& Kegan Paul, 1979, (pp.75-176)

Geschlecht, différence sexuelle, différence ontológique, In. Cahier de l'herne, n45, ed. De l'herne, 1983, pp.419-430

. The ear of the other: otobiography, transference, translation, tradução de Peggy Kamuf, New york, Schocken books, 1985

Survivre, In. Parages, Paris: Galilée, 1986, pp. 117-218

De l'esprit: Heidegger et la question, Paris: ed. Galilée. 1987

Del espíritu: Heidegger y la cuestión, tradução de Alejandro Madrid-

Zan, Escuela de filosofia universidad ARCIS. 1987. Disponível em: www. Philosophia.cl , Acesso em: 8 de março de 2016 
A Diferença In. Margens da filosofia, tradução de Joaquim torres

Costa e Antônio M. Magalhães. Campinas, SP: Papirus, 1991, p.33-64

- Timpanizar a filosofia In. Margens da filosofia, tradução de

Joaquim torres Costa e Antônio M. Magalhães. Campinas, SP: Papirus, 1991, p.11-32

- Ousia gramme In. Margens da filosofia, tradução de Joaquim torres Costa e Antônio M. Magalhães. Campinas, SP: Papirus, 1991, p. 65-100.

Os fins do homem In. Margens da filosofia, tradução de Joaquim torres Costa e Antônio M. Magalhães. Campinas, SP: Papirus, 1991, p.149-177

. Margens da filosofia, tradução de Joaquim torres Costa e Antônio

M. Magalhães. Campinas, SP: Papirus, 1991

Heidegger, l'enfer des philosophes In. Point de suspension, Paris: ed.

Galilée, 1992, p.193-202

Il faut bien manger ou le calcul du sujet In. Points de suspension.

Paris: ed. Galilée 1992, p.269-302

Passages - du traumatisme à la promesse In. Points de suspension.

Paris: ed. Galilée, 1992, p.385-410

Politiques de L'amitié: suivi de L'oreille de Heidegger, Paris:

Galilée, 1994.

Le monolinguisme de l'autre: ou la prothèse d'origine, Paris:

Galilée, 1996.

Sobre a fenomenologia, de Antoine Spire en Staccato, programa televisivo de France Culturel, de 6 de julho de 1999, Disponível em: http://redaprenderycambiar.com.ar/derrida/textos/fenomenologia.htm Acesso em: $\underline{10 \text { de abril de } 2015}$

. Fé e saber: as duas fontes da "religião" nos limites da simples razão, In. VATTIMO, Gianni \& DERRIDA, jacques, A Religião: o seminário de Capri, São Paulo: Estação liberdade, tradução de Guilherme joão de freitas teixeira, 2000.

. La phénomenologie et la clôture de la métaphysique. Introduction

à la pensée de Husserl. In. Derrida et la phénoménologie. Revue de Phénoménologie Alter n.8, 2000, p.69-84

. O monolinguismo do outro ou a prótese de origem, Campo das

Letras: Porto, tradução de Fernanda Bernardo. 2001 
Torres de Babel, Belo Horizonte: Ed. UFMG, tradução de Junia

Barreto. 2002.

A quién dar (saber no saber) In. Dar la muerte. tradução de Cristina de Peretti e Paco Vidarte. Barcelona: ed. Paidós, 2006, pp.65-94

Força de lei: o fundamento místico da autoridade, São Paulo, Martins Fontes, tradução de Leyla Perrone-Moisés. 2007

At this very moment in this work Here I Am In. Psyché: Inventions of the other I, tradução de Ruben Berezdivin e Peggy Kamuf, California: Stanford university press, 2007, p. 143-190

Psyche: Inventions of the Other vol.II California: Stanford University press, 2008.

Geschlecht I: Sexual difference, Ontological difference. In. Psyche, Inventions of the Other vol.II, tradução de Ruben Bevezdivin e Elizabeth Rottenberg, California: Stanford university press, 2008, p.7-26.

A number of Yes, In. Psyché: Inventions of the other II, tradução de Brian Holmes, California: Stanford university press, 2008, pp.231-240

Heidegger's Hand (Geschlecht II) In. Psyche, Inventions of the Other vol.II, California: Stanford university press, 2008, p.27-62.

Letter to a Japanese In. Psyche, Inventions of the Other vol.II, tradução de David Wood e Andrew Benjamin, California: Stanford university press, 2008, p. 1-6

El animal que luego estoy si(gui)endo, Cristina de Peretti e Cristna Rodríguez Marciel, Madrid: Editorial Trotta, 2008.

. Heidegger: la question de l'Être et l'Histoire, Paris: ed. Galilée. 2013.

Le survivant, le sursis, le sursaut, In. Penser à ne pas voir. Paris: ed. De la différence, 2014. p.364-369

DASTUR, Françoise. Heidegger, Derrida et la question de la différence, In. Derrida, la tradition de la philosophie, Paris: Galilée, 2008, p.87-108

DASTUR, Françoise e CABESTAN, Philip. Daseinsanalyse: phénoménologie et psychiatrie, Paris: J. vrin, 2011.

Daseinsanalise: fenomenologia e psicanálise, tradução de Alexandre de carvalho Rio de janeiro: Via verita, 2015.

DUARTE, A. Vidas em Risco: critica do presente em Heidegger, Arendt e 
Foucault, 1.ed. Rio de Janeiro: Forense Universitária, 2010.

DUQUE-ESTRADA, Elizabeth M. Nas entrelinhas do talvez: Derrida e a literatura, Rio de janeiro: ed. Puc-Rio: ed. Via Verita, 2014.

DUQUE-ESTRADA, Paulo C., Ciência e Pós-representação: Notas sobre Heidegger. Política e Trabalho. Revista de Ciências Sociais, ano 22, n. 24, p. 59 71. João Pessoa: PPGS - UFPB, 2006.

DUQUE-ESTRADA, Paulo C. (org.), Espectros de Derrida. Rio de Janeiro: NAU Editora: Ed. PUC-Rio, 2008.

Sobretudo... o perdão - (im)possibilidade, alteridade, afirmação

In. DUQUE-ESTRADA, Paulo C. (org.), Espectros de Derrida. Rio de Janeiro: NAU Editora: Ed. PUC-Rio, 2008, p.13-40.

HAAR, Michel Heidegger e a essência do homem, Trad. Ana Cristina Alves. Lisboa: Instituto Piaget, 1990.

HEIDEGGER, Martin. Brief über den Humanismus In. Platons Lehre von der Wahrheit, 1947, p.18) Disponível em: http://laboratoirefig.fr/wpcontent/uploads/2016/04/HEIDEGGER-

brief_u\%CC\%88ber_den_humanismus.pdf Acesso em: 4 de março de 2016.

The question of Being, Tradução de william kluback and jean $t$. wilde New york, twayne publishers inc., 1958

Que é metafísica? In: Conferências e escritos filosóficos. Tradução Ernildo Stein. 1.ed. São Paulo: Abril Cultural, 1973, p.223-262. (Os pensadores). Sobre a essência da verdade. In: Conferências e escritos filosóficos. Trad. Ernildo Stein. 1.ed. São Paulo: Abril Cultural, 1973, p.325-344. (Os pensadores).

Sobre o humanismo: Carta a Jean Beaufret, Paris. In: Conferências e escritos filosóficos. Trad. Ernildo Stein. 1.ed. São Paulo: Abril Cultural, 1973, p.345-374. (Os pensadores).

- A constituição Onto-teo-lógica da Metafísica In. Identidade e diferença (Conferências e escritos filosóficos), 1973, p.387-400 (Os pensadores).

. O princípio da identidade In. Identidade e diferença (Conferências e escritos filosóficos), 1973, p.377-387 (Os pensadores).

. Introdução à metafisica, tradução de emmanuel carneiro leão, 4ed, ed. Tempo brasileiro, rio de janeiro, 1999.

Ontología: Hermenéutica de la facticidad. Madrid: Alianza 
editorial. 1999.

Seminários de Zollikon, tradução de Gabriela Arnhold e Maria de Fátima de Almeida Prado. Petrópolis: ed. Vozes, 2001.

- Serenidade, tradução de maria madalena andrade e olga santos lisboa: instituto piaget, 2001.

. O dito de Anaximandro In. Caminhos da floresta, tradução de João Constâncio, Lisboa: Fundação Calouste Gulbenkian, 2002. P.369-440

O tempo da imagem no mundo, In. Caminhos de Floresta, tradução de alexandre Franco de Sá, Lisboa: Fundação Calouste Gulbenkian, 2002, p.95-120

Os Conceitos Fundamentais da Metafísica: Mundo, Finitude,

Solidão. Trad. Marco Casanova. 1.ed. Rio de Janeiro: Forense Universitária. 2006 El problema de la transcendencia y el problema de Ser y tiempo [§10] In. Princípios metafísicos de la lógica, tradução de Juan josé garcía norro. 3ed. Revisada, Madrid: Ed. Editorial sintesis, 2007. p.159-180 A questão da técnica (Die Frage nach der Technik). tradução de Marco Aurélio Werle. Scientiae Studia, São Paulo, v.5, n.3, p.375-398, 2007. Introdução à Filosofia, Trad. Marcos Casanova, 1.ed. São Paulo: Martins Fontes, 2008.

. Ser e Tempo, tradução de Márcia Cavalcante. 4.ed. Petrópolis: Vozes. 2009.

. La sentencia de anaximandro In. Caminos de bosque, tradução de helena cortés y arturo leyte. Madrid: alianza editorial 2010.

. Ser e tempo, tradução de Fausto Castilho. Petrópolis: ed. Vozes, 2012 (edição bilíngue)

HEPBURN, Alexa. Derrida and Psychology: Deconstruction and its ab/uses in critical and discursive psychologies. Theory and Psychology, Sage publications, v9, n5, p.639-665, 1999.

KOFMAN, Sarah. Lectures de Derrida. Paris: Galilée. 1984

KIERKEGAARD, Soren. Desespero Humano: doença até a morte. Trad. Wolfgang Leo Maar. 1.ed. São Paulo: Abril Cultural. 1974a. p.329-421. (Os pensadores).

. Temor e tremor, Trad. Wolfgang Leo Maar. 1.ed. São Paulo: Abril S.A. 1974b, p.249-328. (Os pensadores). 
Mi Punto de Vista. Trad. José Miguel Velloso. 1. Ed. Madrid: Aguilar, 1988.

A repetição. Trad. José Miranda Justo. Lisboa: Relógio d’Água, 2009. . O conceito de angústia. Trad. Álvaro Luiz Valls. Petrópolis, RJ: Vozes; São Paulo, SP: Editora Universitária São Francisco, 2010.

KRELL, David Farrel, Phantoms of the Other: Four generations of Derrida's Geschlecht, New York: Suny Press, 2015.

LACOUE-LABARTHE, P. \& NANCY, J. (ed.) Les fins de l'homme: à partir du travail de Jacques Derrida. Paris: Hermann, 2013.

LEVINAS, Emmanuel. Autrement qu'être ou au-delà de l'essence, Paris: M. Nijhoffp - (Phaenomenologica 54), 1974.

LISPECTOR, Clarice. Água viva, Rio de janeiro: Rocco, 1998.

MAJOR, René (org), Derrida: Pour les temps à venir, Paris: stock, 2007.

NANCY, Jean-luc, Ipso facto et demens In. MAJOR, René (org), Derrida: Pour les temps à venir, Paris: stock, 2007, p.118-139

ROGOZINSKY, Jacob, Cryptes de Derrida, France: Lignes, 2014.

SARTRE, Jean. P. A infância de um chefe. In $O$ muro. Tradução de H. Alcântara Silveira. Rio de Janeiro: Nova Fronteira, 2005.

Tradução do texto de Jean Paul Sartre: Une Idée fondamentale de la phenoménologie de Husserl: l'intentionnalité In. Situations I. (1947). Tradução de Ricardo Leon Lopes, VEREDAS FAVIP, Caruaru, Vol. 2, n. 01, pp. 102-107, jan./jun. 2005.

SEBBAH, François-David, "Déconstruire, c'est dire oui”. Déconstruction et réduction. In. Derrida et la phénoménologie. Revue de Phénoménologie Alter n.8, 2000, p.223-236.

L'épreuve de la limite: Derrida, Henry, Levinas et la phénoménologie. Paris: Presses Universitaitres de France, 2001.

SEIXAS, Raul, Por quem os sinos dobram (faixa 5). Albúm: Por quem os sinos dobram, 1 CD, Gravadora WEA, produtora: Gastão Lamounier, duração 25:51, 1979.

STEIN, Ernildo. Introdução ao pensamento de Martin Heidegger, Porto Alegre: Edipucrs 2011. 